\title{
UTILIZAÇÃO DE PRÉ-MOLDADOS EM EDIFÍCIOS DE ALVENARIA ESTRUTURAL
}

\author{
Fabiana Cristina Mamede
}

\begin{abstract}
Dissertação apresentada à Escola de Engenharia de São Carlos da Universidade de São Paulo, como parte dos requisitos para obtenção do título de Mestre em Engenharia de Estruturas.
\end{abstract}

ORIENTADOR: Prof. Dr. Marcio Roberto Silva Corrêa

São Carlos

2001 
“Grande é a tarefa que nos espera. Para todos os seres humanos constitui quase um dever pensar que, o que já se tiver realizado é sempre pouco em comparação com o que resta por fazer. " 
"Se algum dia homem feito e realizado, sentires que a terra cede a teus pés, que tuas obras desmoronam, que não há ninguém à tua volta para te estender a mão, esquece a tua maturidade, passa pela tua mocidade, volta à tua infância e balbucia, entre lágrimas e esperanças, as últimas palavras que sempre te restarão na alma: Minha Mãe, Meu Pai."

(Rui Barborsa)

Aos meus pais, sincera e afetuosamente dedica o autor. 
Agradeço ao professor Márcio Corrêa, que mesmo à distância, conduziu de forma excelente a orientação deste trabalho.

Ao Conselho Nacional de Desenvolvimento Científico e Tecnológico (CNPQ), pelo incentivo à pesquisa.

À todos os colegas, professores e funcionários do Departamento de Estruturas da EESC/USP pela colaboração.

À Suzana pelos ensinamentos e, principalmente, pela amizade.

Ao Luciano minha mais profunda gratidão pela ajuda e paciência no decorrer deste trabalho.

Aos colegas da TecSof Engenharia de Estruturas, com quem muito aprendi.

À professora Silvia Mamede pelo dedicado e maravilhoso trabalho a favor da língua portuguesa.

À minha família, em especial aos meus pais, minha irmã e meus avós pela presença constante em minha vida.

À todos que colaboraram para a realização deste trabalho. 
1.1. Objetivos

1.1.1. Objetivo geral

1.1.2. Objetivos específicos

1.2. Justificativas 3

1.3. Apresentação do Trabalho 
2.1. Definição de Pré-Moldado Leve 7

2.2. Racionalização 8

2.3. Os Pré-moldados e o Aumento da Produtividade 13

2.4. Padronização 14

2.5. Organização do Canteiro de Obra 15

2.6. Viabilidade do Uso de Pré-Moldados Leves em Conjuntos Habitacionais

2.7. Elementos Propostos para Estudo 19

3. COORDENAÇÃO MODULAR 23

3.1. Histórico 24

3.2. Conceitos que Influem na Coordenação Modular 25

3.2.1. Sistema de Referência 25

3.2.2. O Módulo 26

$\begin{array}{ll}\text { 3.2.3. O Ajuste Modular } & 27\end{array}$

3.3. Modulação na Alvenaria Estrutural 28

3.3.1. Os Blocos 29

3.3.2. As Juntas 31

3.3.3. Os Ajustes 33

3.4. Aplicação dos Conceitos de Coordenação Modular na Alvenaria Estrutural $\begin{array}{ll}\text { 3.4.1. Amarração } & 35\end{array}$

3.4.2. Exemplo de Modulação com Amarração Direta 36

3.5. Modulação Altimétrica 44

3.6. Considerações Finais 48

4. ESCADAS PRÉ-MOLDADAS $\quad 49$ 
4.1. Escada Pré-moldada Composta por Peças de Grandes Dimensões $\quad 50$

4.2. Escada Pré-moldada Composta por Vários Elementos 52

4.2.1. Escada Nervurada 53

4.2.2. Escada Jacaré $\quad 54$

4.2.3. Roteiro de Projeto 57

A. Definições preliminares 58

B. Concepção dos elementos pré-moldados 59

C. Dimensionamento 60

D. Desenho final - Detalhamento 62

4.2.4. Exemplo de projeto 63

A. Definições Preliminares 63

B. Concepção dos elementos 64

C. Dimensionamento e detalhamento 68

D. Desenho final - Detalhamento 73

5. ABERTURAS $\quad 77$

$\begin{array}{ll}\text { 5.1. Esquadrias } & 78\end{array}$

$\begin{array}{ll}\text { 5.1.1. Portas } & 79\end{array}$

5.1.2. Procedimentos Executivos para Instalação de Portas de Madeira 80

5.1.3. Janelas 87

5.1.4. Procedimentos Executivos para Instalação de Janelas de Alumínio 88

5.1.5. Caixilhos Pré-moldados 96

5.2. Simulação do Comportamento das Aberturas nas Alvenarias Estruturais

5.2.1. Coleta de Dados da Freqüência das Aberturas em Edifícios Habitacionais 
5.3.1. As Vergas em Edifícios de Alvenaria Estrutural 108

$\begin{array}{ll}\text { 5.3.2. Contraverga } & 118\end{array}$

5.4. Contramarco Pré-moldado 119

5.5. Ajuste Dimensional 128

5.5.1. Caixas Suporte de Aparelhos de Ar Condicionado 128

5.5.2. Elementos Vazados Modulares de Concreto 130

5.5.3. Peças Compensadoras de Ajuste Dimensional 131

$\begin{array}{ll}\text { 5.6. Considerações Finais } & 133\end{array}$

6. PRODUÇÃO DOS PRÉ-MOLDADOS 135

$\begin{array}{ll}\text { 6.1. Transporte e Manuseio } & 136\end{array}$

6.1.1. Ergonomia 136

6.1.2. Equipamentos de Transporte 138

6.2. Fluxograma da Produção 140

6.3. Controle de Qualidade de Produção dos Pré-Moldados 141

6.3.1. Controle de Materiais 143

6.3.2. Controle de Formas 143

6.3.3. Controle das Armaduras 146

6.3.4. Adensamento 148

6.3.5. Cura 150

A. Cura por Aspersão 151

B. Cura por Imersão 151

C. Cura Térmica 152

6.3.6. Análise e Inspeção da Peça Concretada 153

6.3.7. Transporte e Armazenamento 154

6.4. Materiais Alternativos 155

6.4.1. Fibras de Polipropileno 155

6.4.2. Concreto Leve 157 
ANEXO A 170

ANEXO B 173 


\section{LISTA DE FIGURAS}

Figura 2.1: Vista superior de um edifício em alvenaria estrutural com incorporação de elementos pré-moldados leves (cortesia do Eng. Márcio Faria)

Figura 2.2: Execução de uma escada pré-moldada (cortesia do Eng. Marcio Faria) 22

Figura 3.1: Triedro axonométrico e projeções que representam os quadriculados modulares de referência (BNH/IDEG, 1976)

Figura 3.2: Exemplo da medida modular, medida de projeto e junta de projeto para uma esquadria (BNH/IDEG, 1976)

Figura 3.3: Bisnaga de assentamento (FRANCO et alii, 1991) 32

Figura 3.4: Enchimento pré-moldado conhecido como "rapadura" 34

Figura 3.5: Interação entre paredes nos cantos (CORRÊA \& RAMALHO, 1996) 35

$\begin{array}{ll}\text { Figura 3.6: Planta de arquitetura } & 37\end{array}$

Figura 3.7: Planta de modulação M-15 da $1^{\text {a }}$ fiada com blocos BL-15 37

Figura 3.8: Amarração de canto e de borda com modulação M-15 e blocos BL-15 38

Figura 3.9: Amarração M-15 de borda com blocos BL-15 e com blocos especiais de $45 \mathrm{~cm}$ de comprimento modular

Figura 3.10: Modulação $M-15$ da $1^{a}$ fiada de blocos BL-15 com emprego do bloco especial de $35 \mathrm{~cm}$ de comprimento modular

Figura 3.11: Modulação M-15 de $1^{\mathrm{a}}$ e $2^{\mathrm{a}}$ fiada da Parede Par01 com auxílio do bloco especial de $35 \mathrm{~cm}$ de comprimento modular

Figura 3.12: Modulação $M-15$ da $1^{a}$ fiada de blocos BL-20

Figura 3.13: Modulação M-15 da $2^{\mathrm{a}}$ fiada de blocos BL-20

Figura 3.14: Amarração (M-15) de canto e borda com blocos BL-20 e bloco especial de $35 \mathrm{~cm}$ de comprimento modular

Figura 3.15: Amarração M-15 de borda com blocos BL-20 com bloco especial de $55 \mathrm{~cm}$ de comprimento modular

Figura 3.16: Esquema de elevação das paredes com blocos jotão e canaleta [a] e blocos jota e compensador [b] 
Figura 3.17: Bloco jota e bloco compensador $\quad 46$

Figura 3.18: Desnível e degrau obtidos com o bloco "jota" 47

Figura 4.1: Escadas pré-moldadas compostas por peças de grandes dimensões 50

Figura 4.2: Forma metálica de escada composta por peças de grandes dimensões 51

Figura 4.3: Escada pré-moldada produzida no canteiro de obra (KISS, 1998) 51

Figura 4.4: Escada pré-moldada espiral (FIP, 1994) 52

Figura 4.5: Escada nervurada 53

Figura 4.6: Elementos constituintes da escada jacaré: degrau [a]; patamar [b] e viga denteada ou viga jacaré [c]

Figura 4.7: Planta da arquitetura da região da escada 64

Figura 4.8: Localização e dimensão dos furos na viga jacaré 65

Figura 4.9: Planta e cortes da escada pré-moldada (cortesia da TecSof Engenharia de Estruturas S/C Ltda) 66

Figura 4.10: Elevação e corte das peças pré-moldadas da escada 67

Figura 4.11: Detalhe da armadura longitudinal da viga denteada 70

Figura 4.12: Vigas denteadas e degrau da escada pré-moldada jacaré (cortesia da TecSof Engenharia de Estruturas S/C Ltda)

Figura 4.13: Patamar e peças complementares de ajuste da escada pré-moldada jacaré (cortesia da TecSof Engenharia de Estruturas S/C Ltda)

Figura 4.14: Peças de ajuste da escada pré-moldada jacaré (cortesia da TecSof Engenharia de Estruturas S/C Ltda)

Figura 5.1: Esquema para instalação de portas com batentes de madeira com uso de espuma de poliuretano

Figura 5.2: Esquema para instalação de portas com batentes de madeira com acerto da modulação altimétrica

Figura 5.3: Esquema para instalação de portas com batentes de madeira com tacos e parafusos

Figura 5.4: Esquema para instalação de batente metálico envolvente

Figura 5.5: Esquema para instalação de batentes metálicos envolventes com acerto da modulação altimétrica

Figura 5.6: Gabarito metálico usado para o requadro do vão da alvenaria

Figura 5.7: Borracha de proteção da espuma de poliuretano [a]; e degradação do poliuretano exposto aos raios UV [b] (cortesia de eng. Marson)

Figura 5.8: Foto da esquadria padronizada instalada vista externamente à edificação [a]; e detalhe do chumbamento da grapa [b] 
Figura 5.9: Contramarco parafusado diretamente na alvenaria [a]; e marco rebitado ao contramarco [b]

Figura 5.10: Pingadeira pré-moldada

Figura 5.11: Resumo esquemático dos procedimentos executivos para instalação de esquadrias de alumínio

Figura 5.12: Esquema de caixilho pré-moldado acabado (WINBLOCK, 1999)

Figura 5.13: Efeito arquitetônico obtido com uso do caixilho pré-moldado (WINBLOCK, 1999)

Figura 5.14: Tensões $\sigma_{\mathrm{x}}$ para $\mathrm{J} 120 \times 120 \times 100\left(\mathrm{kN} / \mathrm{cm}^{2}\right)$

Figura 5.15: Tensões $\sigma_{y}$ para $J 120 \times 120 \times 100\left(\mathrm{kN} / \mathrm{cm}^{2}\right)$

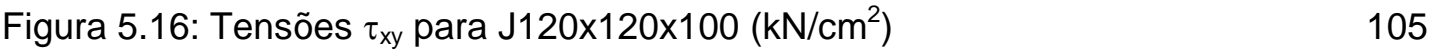

Figura 5.17: Tensões $\sigma_{y}$ para $\mathrm{P} 100\left(\mathrm{kN} / \mathrm{cm}^{2}\right) \quad 106$

$\begin{array}{ll}\text { Figura 5.18: Tensões } \sigma_{x} \text { para } \mathrm{P} 100\left(\mathrm{kN} / \mathrm{cm}^{2}\right) & 107\end{array}$

Figura 5.19: Esquema de distribuição do carregamento vertical para o dimensionamento de vergas segundo especificações da ABNT (1989) 108

Figura 5.20: Esquema de distribuição de cargas concentradas verticais para o dimensionamento de vergas segundo especificações da ABNT (1989) 109

Figura 5.21: Visualização do ajuste dimensional, proporcionado pela verga prémoldada, para portas com batentes de madeira

Figura 5.22: Verga pré-moldada sobre portas padronizadas com folhas e batentes de madeira, para ajuste de $3 \mathrm{~cm}$ na altura

Figura 5.23: Geometria e dimensões de uma verga pré-moldada sobre portas com folha de madeira e batente metálico envolvente para ajuste de $7 \mathrm{~cm}$ na altura

Figura 5.24: Situação de cálculo da tensão de cisalhamento da verga

Figura 5.25: Detalhamento das armaduras da verga pré-moldada

Figura 5.26: Verga com abertura nos apoios para passagem vertical

Figura 5.27: Elevação com portas adjacentes

Figura 5.28: Vergas sobre portas adjacentes

Figura 5.29: Planta esquemática de interseção em "L" entre paredes 116

Figura 5.30: Elevação de paredes que se interceptam 116

Figura 5.31:Vergas sobre portas adjacentes em "L"

Figura 5.32: Verga com chanfro de $45^{\circ}$ na extremidade para uso sobre portas adjacentes em "L"

Figura 5.33: Régua de ajuste 
Figura 5.34: Representação da régua de ajuste na elevação da alvenaria

Figura 5.35: Abertura no canto da parede na cinta à meia altura propiciando a passagem da armadura

Figura 5.36: Assentamento de contramarco pré-moldado (Giassetti, 2000)

Figura 5.37: Vista frontal e cortes de esquadria composta por contramarco pré-moldado

Figura 5.38: Etapas para o assentamento do contramarco pré-moldado adotado pela ENCOL (FRANCO et alii, 1991c)

Figura 5.39: Contramarco formado por travessas e montantes produzidos isolados (WINBLOCK, 1999)

Figura 5.40: Detalhe de encaixe entre as travessas pré-moldadas do contramarco (WINBLOCK, 1999)

Figura 5.41: Caixa para ar condicionado

Figura 5.42: Forma para caixa suporte de ar condicionado - produção no canteiro da obra [a]; e aspecto da caixa de ar condicionado assentada na alvenaria [b]

Figura 5.43: Foto da fachada de um edifício em alvenaria estrutural com aplicação de elementos vazados modulares de concreto

Figura 5.44: Ajuste na dimensão do vão da porta com rapadura [a]; e ajuste com régua parafusada [b]

Figura 5.45: Elevação da alvenaria da região da escada com solução usando enchimentos [a]; e solução com pré-moldados [b]

Figura 6.1: Figura de carro porta palete transportando bloco

Figura 6.2: Fluxograma das atividades de produção de pré-moldados leves

Figura 6.3: Divisão do controle de qualidade (RODRIGUES, 1989)

Figura 6.4: Ilustração de vergas com bolhas superficiais

Figura 6.5: Contramarcos pré-moldados empilhados em forma de paletes

Figura 6.6: Moinho de reciclagem de resíduos no canteiro da obra

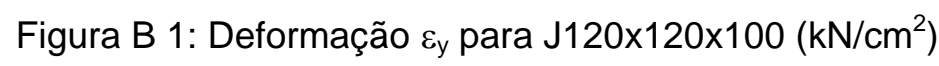

Figura B 2: Deformação $\varepsilon_{y}$ para JE120x120x100 (kN/cm²)

Figura B 3: Tensões $\sigma_{y}$ para JE120x120x100 $\left(\mathrm{kN} / \mathrm{cm}^{2}\right)$

Figura B 4: Tensões $\sigma_{x}$ para JE120x120x100 $\left(\mathrm{kN} / \mathrm{cm}^{2}\right)$

Figura B 5: Tensões $\tau_{x y}$ para JE120x120x100 $\left(\mathrm{kN} / \mathrm{cm}^{2}\right)$

Figura B 6: Tensões principais $\sigma_{1}$ para $J 120 \times 120 \times 100\left(\mathrm{kN} / \mathrm{cm}^{2}\right)$

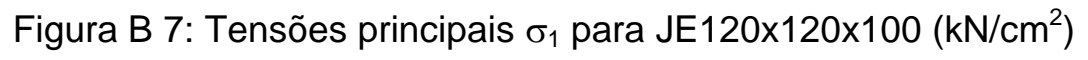




\section{LISTA DE TABELAS}

Tabela 2.1: Apresentação dos pré-moldados propostos para o estudo.

Tabela 3.1: Dimensões reais dos blocos modulares e submodulares de concreto segundo a NBR 6136.

30

Tabela 3.2: Dimensões reais dos blocos cerâmicos segundo a NBR 7171. 30

Tabela 3.3: Dimensões usuais de mercado para blocos de concreto M-15 e M-20. 31

Tabela 3.4: Dimensões usuais de mercado para blocos cerâmicos M -15 e M-20. 31

Tabela 3.5: Tabela das alturas usuais dos aparelhos da edificação segundo ROSSO (1976).

Tabela 5.1: Altura $(\mathrm{cm})$ de portas padronizadas e ajustes com relação à modulação da alvenaria estrutural.

Tabela 5.2: Quadro comparativo de vantagens e desvantagens entre portas com batentes metálicos e de madeira.

Tabela 5.3: Quadro comparativo de vantagens e desvantagens dos procedimentos executivos das janelas.

Tabela 5.4: Análise do levantamento dos valores usuais de aberturas de portas e janelas de edifícios de alvenaria estrutural com alvenaria modular BL-15.

Tabela 5.5: Análise do levantamento dos valores usuais de aberturas de portas e janelas de edifícios de alvenaria estrutural com alvenaria modular BL-20.

Tabela 5.6: Valores das tensões admissíveis na alvenaria não armada.

Tabela 5.7: Pesos de vergas pré-moldadas em função do comprimento do vão da abertura.

Tabela 5.8: Cálculo da armadura longitudinal e transversal das vergas pré-moldadas em função do vão da abertura e verificação da tensão de cisalhamento e da tensão de contato na alvenaria. 
Tabela 5.9: Parâmetros característicos e dosagem de argamassas e suas propriedades, baseados na experiência do grupo de São Carlos (HANAI, 1992).

Tabela 6.1: Limites de cargas (em kg) segundo indicações da Organização Internacional do Trabalho (OIT), 1969.

Tabela 6.2: Ocorrência de problemas em elementos pré-moldados leves e suas causas mais comuns (adaptada de BENTES, 1993).

Tabela 6.3: Número de reutilizações de formas em função do tipo de material adotado (ORDOÑEZ apud EL DEBS, 2000).

Tabela 6.4: Requisitos das formas a serem verificados antes da liberação para concretagem.

Tabela 6.5: Ocorrências de problemas em peças pré-moldadas causadas por adensamento inadequado e suas causas mais comuns.

Tabela 6.6: Propriedades do concreto leve estrutural.

Tabela 6.7: Coeficientes de ralação recomendados pelo Rilem 


\section{LISTA DE SÍMBOLOS}

$A_{p} \quad$ Área da seção bruta do parafuso

$A_{S} \quad$ Área de seção transversal da armadura longitudinal tracionada

$\mathrm{A}_{\mathrm{SW}}$ Área da seção transversal das barras da armadura de cisalhamento

$E_{\mathrm{s}} \quad$ Módulo de deformação longitudinal do aço

$E_{p a} \quad$ Módulo de deformação longitudinal da parede

$F_{d, f r e q}$ Combinação freqüente das ações em serviço

$\mathrm{F}_{\mathrm{g}, \mathrm{k}} \quad$ Ações variáveis característico

$F_{g, k} \quad$ Ações permanente característico

Frara Combinação rara das ações em serviço

$\mathrm{F}_{\mathrm{u}} \quad$ Força última

M Valor básico do módulo

$M_{\text {at }} \quad$ Momento fletor atuante

$\mathrm{M}_{\mathrm{cr}} \quad$ Momento fletor de fissuração

$M_{d}$,rara Momento fletor calculado para combinação rara das ações

$M_{\text {freq }} \quad$ Momento fletor calculado para combinação freqüente das ações

$\mathrm{M}_{\mathrm{k}} \quad$ Momento fletor característico

$\mathrm{R}_{\mathrm{n}} \quad$ Resistência nominal

$\mathrm{R}_{\mathrm{V}} \quad$ Resistência de cálculo à força cortante

$\mathrm{V}_{\mathrm{d}} \quad$ Força cortante de cálculo 
$V_{\text {du }} \quad$ Força cortante última de cálculo

$\mathrm{V}_{\mathrm{k}} \quad$ Força cortante característica

$\mathrm{a}_{\text {is }} \quad$ Flecha imediata para ação suplementar

$\mathrm{a}_{\mathrm{t}} \quad$ Flecha total para todas a ações

$\mathrm{a}_{\mathrm{tl}} \quad$ Flecha total para ações de longa duração

$\mathrm{f}_{\mathrm{bk}} \quad$ Resistência característica à compressão do bloco

$f_{\text {ck }}$ Resistência característica do concreto à compressão

$f_{\text {ctk }}$ Resistência característica do concreto à tração na flexão

$f_{\text {con }} \quad$ Tensão de contato

$\mathrm{f}_{\mathrm{tk}} \quad$ Resistência característica do concreto à tração

$\mathrm{f}_{\mathrm{yk}} \quad$ Resistência característica do aço à tração

$f_{u} \quad$ Limite de resistência à tração do aço, valor nominal especificado

$\phi \quad$ Diâmetro das barras da armaduras

$\phi_{\mathrm{V}} \quad$ Coeficiente de resistência à força cortante

$\tau$ wd Tensão convencional de cisalhamento de cálculo

$\tau_{\text {wu }} \quad$ Tensão última de cisalhamento

$\tau_{\text {xy }} \quad$ Tensão tangencial

E y Deformação no plano horizontal

$\eta_{b} \quad$ Coeficiente de conformação superficial das barras da armadura

$\rho_{\mathrm{r}} \quad$ Taxa geométrica da armadura em relação à $A_{c r}$

$\sigma_{\mathrm{S}} \quad$ Tensão normal de tração na armadura

$\sigma_{\mathrm{X}} \quad$ Tensão normal no plano horizontal

$\sigma_{y} \quad$ Tensão normal no plano vertical 
MAMEDE, F.C. (2001). Utilização de pré-moldados em edifícios de alvenaria estrutural. São Carlos, 2001, 187p. Dissertação (Mestrado) - Escola de Engenharia de São Carlos, Universidade de São Paulo.

Elementos pré-moldados são uma opção para aumentar a racionalização no processo construtivo em alvenaria estrutural. Eles associam-se a particularidades desse processo com relação à rapidez de execução, rígido controle de qualidade, coordenação modular e alto nível organizacional da produção.

Este trabalho pesquisou os pré-moldados freqüentemente utilizados em edifícios de alvenaria estrutural, tais como: blocos, escadas, contramarcos, vergas e peças de ajuste dimensional.

Os pré-moldados foram analisados em seus aspectos estruturais, dimensionais e geométricos, respeitando-se as características que os tornam viáveis no aspecto construtivo, como a facilidade de produção, de manuseio e de transporte. Considerou-se, sempre, a coordenação modular e a compatibilização dimensional entre os componentes e subsistemas. Quando necessário, foram apresentados roteiro e exemplo de projeto, assim como quadros comparativos de vantagens e desvantagens.

Palavras-chave: pré-moldados leves; alvenaria estrutural; racionalização; edifícios. 


\section{ABSTRACT}

MAMEDE, F.C. (2001). Precast concrete elements in structural masonry buildings. São Carlos, 2001, 187p. Dissertação (Mestrado) - Escola de Engenharia de São Carlos, Universidade de São Paulo.

Precast concrete elements are a good option to improving the rationalization in structural masonry building process. They are related to the following features of this process: reduction of building times consumption, strict quality control, modular coordination and high level of manufacturing organization.

This work deals with precast concrete elements commonly used in structural masonry buildings, such as: blocks, stairs, window's frames, lintels and pieces for dimensional adjustment.

Structural, dimensional and geometrical characteristcs of precast concrete elements are analysed, considering the viability of production, transporting and handling the pieces. Modular coordination and the dimensional compatibility are always taken in account. Guidelines, design examples and comparative tables with pros and cons are inserted when convenient.

Keywords: structural masonry; lightweight precast concrete elements; rationalization; buildings. 


\section{INTRODUÇÃO}

processo construtivo em alvenaria estrutural foi introduzido no Brasil
na década de 60 e consolidou-se nos anos procedentes com a evolução técnica e o desenvolvimento de normas brasileiras.

Este processo construtivo atendeu, e ainda atende, com sucesso, ao desafio de construir-se no prazo, com qualidade e com baixo custo, as casas e os edifícios habitacionais. O aperfeiçoamento dos métodos de cálculo, ao longo dos anos, tornou possível desenvolver edifícios de diversos padrões e estruturas cada vez mais altas.

A grande vantagem do uso da alvenaria estrutural está no alto potencial de racionalização dos materiais e dos métodos construtivos utilizados na construção de edifícios.

A racionalização e a industrialização caminham juntas. A aplicação de medidas racionalizadas aumenta o nível organizacional dos processos, que é a base da industrialização. Entende-se por industrialização da construção o "processo evolutivo que, através de ações organizacionais e da implementação de inovações tecnológicas, métodos de trabalho, técnicas de planejamento e controle objetiva incrementar a produtividade e o nível de produção e aprimorar o desempenho da atividade construtiva" (FRANCO, 1992). 
A industrialização apresenta caráter repetitivo; bem representado pela pré-moldagem que reduz os desperdícios e reflete diretamente na produtividade da mão-de-obra. No entanto, antes de se tornarem muito repetitivas, os procedimentos e os processos devem ser altamente coerentes, para não se correr o risco de reproduzirem em larga escala, também os erros.

Os pré-moldados leves, tema principal deste trabalho, são meios para se incrementar o nível de racionalização que a alvenaria estrutural é capaz de atingir, com a industrialização da construção.

Os elementos pré-moldados são inseridos no processo construtivo sem que haja mudanças bruscas da base produtiva que caracteriza o setor. Notadamente na alvenaria estrutural, eles irão associar-se às particularidades deste processo construtivo, com relação à rapidez de execução, ao controle de qualidade, à coordenação modular e à diminuição das improvisações e dos desperdícios.

\subsection{Objetivos}

\subsubsection{Objetivo geral}

O objetivo da presente pesquisa é estudar os mais importantes tipos de pré-moldados leves que possam ser utilizados em edifícios de alvenaria estrutural. Pretende-se analisar, sob o ponto de vista estrutural, tais elementos, respeitando-se sempre as características que os tornam viáveis no aspecto construtivo, tais como: facilidade de produção, de manuseio e de transporte; compatibilidade com os outros subsistemas; e respeito às modulações planimétrica e altimétrica da edificação. Serão priorizadas as alternativas mais adequadas à prática corrente de construção no Brasil. 


\subsubsection{Objetivos específicos}

Os objetivos específicos da pesquisa são:

- Formação de base teórica sobre conceitos de racionalização, produtividade, padronização, organização da produção e coordenação dimensional, que servirão de respaldo teórico para a concepção dos prémoldados.

- Obtenção de experiências práticas com visitas às obras para auxiliar a análise e a seleção dos pré-moldados leves, viáveis de serem empregados em edifícios de alvenaria estrutural.

- Estudo da coordenação modular e aplicação dos conceitos adquiridos na modulação altimétrica e planimétrica da alvenaria.

- Análise dos elementos pré-moldados leves sob aspectos estruturais; quando necessário, apresentação de modelo de dimensionamento, detalhamento da armadura e indicações de considerações no projeto.

- Análise dos elementos pré-moldados sob aspectos executivos, como facilidade de produção e de transporte e interferências com outros subsistemas, listando-se vantagens e desvantagens em comparação com outros procedimentos executivos.

- Caracterização da produção dos pré-moldados, baseada na redação de diversos autores especialistas no tema.

\subsection{Justificativas}

Atualmente, tem havido uma progressiva busca de racionalização dos processos construtivos, visando ao aumento da produtividade e à redução dos custos de construção, resultando em uma demanda crescente por projetos de edifícios em alvenaria estrutural racionalizada. 
A grande competitividade do mercado atual, no entanto, demanda soluções que, associadas ao processo construtivo em alvenaria estrutural, melhorem a eficiência do processo, eliminando etapas construtivas, minimizando interferências entre os subsistemas e elevando a qualidade do produto final. Adotar soluções voltadas à industrialização, principalmente com a pré-moldagem, pode ser um caminho para melhorar a eficiência do processo.

A presente pesquisa pretende estudar os pré-moldados compatíveis com os edifícios de alvenaria estrutural, para favorecer a industrialização e a racionalização do processo, bem como a redução do prazo de execução da obra e com isso, elevar a produtividade e os lucros da empresa construtora.

\subsection{Apresentação do Trabalho}

No capítulo inicial, é feita uma abordagem sumária do trabalho para que o leitor se situe no contexto da pesquisa e no tema abordado.

No capítulo 2, intitulado "Aspectos Gerais", são descritos alguns conceitos primordiais para o desenvolvimento da pesquisa. Os conceitos relacionados ao setor da Construção Civil abordam: racionalização, produtividade, padronização, organização do canteiro de obra, sob a ótica de autores especializados no assunto. Também, neste capítulo, são apresentados os pré-moldados escolhidos para serem objeto de estudo.

O capítulo seguinte é destinado ao estudo da coordenação modular baseado nas especificações da normalização brasileira (hoje desatualizada), porém, estendendo-se às particularidades da modulação altimétrica e planimétrica da alvenaria estrutural. São demonstrados exemplos de modulação com amarração direta e descritas algumas peculiaridades da coordenação dimensional entre subsistemas.

No capítulo 4, são tratadas as escadas pré-moldadas, divididas em escadas compostas por peças de grandes dimensões e compostas por vários 
elementos de pequena espessura, passíveis de manuseio sem equipamentos especiais de içamento. O enfoque principal, no entanto, está voltado ao último tipo, em especial às escadas jacaré. Será apresentado um roteiro de projeto de escada jacaré, contendo: definições preliminares, concepção dos elementos pré-moldados, dimensionamento e detalhamento da armadura. O roteiro de projeto discutido terá completo entendimento com a aplicação em um exemplo.

O capítulo 5, sobre aberturas na alvenaria, traz discussões a respeito de alguns procedimentos executivos que visem à racionalização para instalação de portas e janelas. Com relação às portas, será proposta a execução de vergas pré-moldadas de concreto, com apresentação de dimensionamento e considerações específicas do projeto. Com relação às janelas, serão apresentados os caixilhos e os contramarcos pré-moldados.

Inserida ainda no capítulo 5, uma análise teórica em elementos finitos do comportamento das aberturas de portas e janelas em painéis isolados de alvenaria com função estrutural, com o objetivo de saber como ocorre o fluxo de tensões ao redor das aberturas. O capítulo finaliza com a breve exposição de caixas suporte de aparelhos de ar condicionado, elementos vazados modulares e peças compensadoras de ajuste dimensional.

A produção de elementos pré-moldados, visando à qualidade do produto é abordada no capítulo 6 que apresenta uma coletânea de informações extraídas da bibliografia existente sobre processo de produção de elementos pré-moldados. Os assuntos incluídos são: transporte e manuseio, aspectos ergonômicos; fluxograma da produção; equipamentos de transporte e materiais alternativos para a execução do concreto.

As conclusões finais deste trabalho são apresentadas no capítulo 7. 


\title{
2. ASPECTOS GERAIS
}

\author{
tualmente, torna-se cada vez mais importante a Construção Civil \\ ser analisada sob aspectos referentes à industrialização por
} emprego racionalizado de técnicas construtivas que viabilizem o aumento da produtividade e a redução de custos.

A Construção Civil tem sido considerada uma indústria atrasada quando comparada a outros ramos industriais, por apresentar, de maneira geral, baixa produtividade, grande desperdício de materiais, morosidade e baixo controle de qualidade (EL DEBS, 2000).

Uma das formas de reduzir esse atraso é empregar técnicas associadas à utilização de elementos pré-moldados de concreto.

É preciso, então, que as novas propostas de racionalização do processo construtivo tradicional incorporem nas suas soluções, as técnicas tradicionais. Dentro dessa diretriz, a pré-fabricação leve em sistemas abertos é, sem dúvida, uma das principais opções, como sugerido por MASSONI (1996).

A aplicação de pré-moldados leves nos processos construtivos tem como objetivo proporcionar um aumento da racionalização construtiva e com isso, elevar a produtividade e reduzir desperdícios e custos.

Nas edificações em que o processo construtivo é em alvenaria estrutural, os pré-moldados leves desempenham papel fundamental, associando-se 
a particularidades deste processo, em relação à rapidez de execução, rígido controle de qualidade e coordenação modular.

FRANCO \& AGOPYAN (1994) afirmam que "na alvenaria estrutural em particular, encontram-se boas condições de implementação de uma ação organizacional em obra. Isto se explica pelo maior detalhamento do projeto em relação às obras convencionais, pela maior padronização na execução dos procedimentos construtivos, bem como pela maior simplicidade inerente ao processo. Assim, pode-se utilizar a organização da produção como ferramenta para se atingir um grau mais elevado de industrialização do processo, aumentando a sua produtividade, o controle na execução dos procedimentos e conseqüentemente a qualidade".

\subsection{Definição de Pré-Moldado Leve}

A Associação Brasileira de Normas Técnicas (1985), NBR 9062, define elemento pré-moldado como aquele que é executado fora do local de utilização definitivo na estrutura, com controle de qualidade especificado nesta mesma norma.

Segundo EL DEBS (2000), pré-moldado leve é aquele que não necessita de equipamentos especiais para transporte e montagem, podendo-se improvisar os equipamentos ou até mesmo atingir a situação em que a montagem possa ser manual.

RODRIGUES (1989) define os pré-moldados leves como aqueles que podem ser manuseados com facilidade, não necessitando de equipamento mecânico para a sua movimentação, como por exemplo, os blocos de alvenaria, placas de vedação, lajes mistas, etc.

Dentre os pré-moldados leves, há uma linha de pesquisa na área da Engenharia Civil que trata de elementos de pequena espessura feitos com matriz à base de cimento, denominando-os de elementos em argamassa armada . 
A argamassa armada, segundo a definição de HANAI (1992), "é um tipo particular de concreto armado, composto por argamassa de cimento e agregado miúdo e armadura difusa, em geral constituída de telas de aço de malhas de pequena abertura, distribuídas em toda a seção transversal da peça".

Neste trabalho, adota-se para a definição de pré-moldados leves, os elementos que podem ser manuseados sem equipamentos especiais de içamento; portanto, são compatíveis com o esforço físico do operário da construção. Em alguns casos, sugerir-se-á uso da tecnologia da argamassa armada para a confecção dos elementos leves.

A capacidade máxima para levantamento de cargas por um operário, segundo as recomendações da Organização Internacional do Trabalho de 1969, é de $50 \mathrm{~kg}$ (GRANDJEAN, 1991).

\subsection{Racionalização}

A nova mentalidade voltada para a produção racionalizada com qualidade, é muito mais que um modismo; é uma questão de sobrevivência para as empresas. A abertura do Brasil para o mercado competitivo mundial, exige da indústria nacional uma rápida adaptação às rigorosas exigências de um consumidor consciente de seus direitos.

O Instituto de Pesquisas Tecnológicas do Estado de São Paulo (IPT) concluiu durante suas pesquisas que "através do processo de racionalização, as empresas procuram obter ganhos de produtividade e minimizar os custos e os prazos, sem uma ruptura da base produtiva que caracteriza o setor" (IPT apud FRANCO, 1992).

Vários autores definem a racionalização da construção; porém, todos concordam em ser este um instrumento para melhorar a qualidade e a produtividade e reduzir os custos. 
ASPECTOS GERAIS

DEPARTAMENTO DE ENGENHARIA DE ESTRUTURAS -EESC/USP

FRANCO (1992) apresenta em sua tese de doutorado, uma coletânea de definições para a racionalização sob a ótica de vários autores, das quais as mais expressivas encontram-se transcritas neste item.

Segundo TRIGO (1978), a racionalização pressupõe a organização, a planificação, a verificação e as técnicas adequadas à melhoria da qualidade e ao acréscimo de produtividade.

Para ROSSO (1980), racionalizar a Construção Civil significa "agir contra os desperdícios de materiais e mão-de-obra e utilizar mais eficientemente o capital" e completa explicando que isso se faz por meio da aplicação de princípios de planejamento e gerenciamento, com objetivo de eliminar a casualidade das decisões.

SABBATINI (1989) propõe sua definição sobre o tema, a qual foi aceita e adotada por vários autores, inclusive neste trabalho. Esta definição prescreve que a "racionalização da construção é o processo dinâmico que torna possível a otimização do uso dos recursos humanos, materiais, organizacionais, tecnológicos e financeiros, visando atingir objetivos fixados nos planos de desenvolvimento de cada país e de acordo com a realidade sócio-econômica própria".

A racionalização deve estar presente em todas as fases do processo, desde as concepções iniciais, passando pelo desenvolvimento do projeto, até atingir a etapa de produção.

Baseado nos estudos de DORNELLES \& SABBATINI (1993), FRANCO (1992), FRANCO \& AGOPYAN (1994), HEINECK \& ANDRADE (1994), dentre outros, são apresentadas algumas diretrizes para a racionalização nas fases de concepção inicial e desenvolvimento de projeto.

Durante a concepção inicial de um projeto, os requisitos do produto devem estar claramente definidos, deve-se direcionar a escolha dos processos construtivos adequados e das tecnologias viáveis, fundamentada nas 
ASPECTOS GERAIS

DEPARTAMENTO DE ENGENHARIA DE ESTRUTURAS -EESC/USP

especificações regionais, nos condicionantes físicos e legais do local em que se situa o empreendimento, no desempenho, na durabilidade, no tempo de execução, na expectativa do empreendedor quanto ao produto e à necessidade do usuário.

O desenvolvimento do projeto é a situação crítica para a implantação de soluções que visem à racionalização, pois, nesta fase, as decisões trazem maior repercussão nos custos, na velocidade e na qualidade dos empreendimentos. As alterações implementadas nesta fase apresentam, de maneira geral, um custo muitas vezes menor que as implementadas nas fases posteriores. As diretrizes para um projeto racionalizado residem em diversos fatores dentre os quais:

- implantação de um sistema de coordenação de projetos;

- integração das equipes de projetistas;

- controle de qualidade do projeto;

- aplicação dos princípios de construtibilidade através da integração do conhecimento e experiência construtiva durante as fases de concepção, planejamento, projeto e execução da obra, visando à simplificação das operações construtivas;

- simplificação e padronização das soluções;

- pré-moldagem de elementos complexos;

- adoção de sistemas de coordenação dimensional, e

- detalhamentos melhorados dos projetos.

A fase de execução da obra, apesar de mais difícil, por implicar em mudanças no setor produtivo, também deve incorporar soluções racionalizadas com a organização da produção que engloba a organização do canteiro de obra, a padronização das técnicas e dos métodos produtivos, o gerenciamento da produção (planejamento e programação), o treinamento e a motivação da mão-de-obra, o uso racional de ferramentas e equipamentos e a aplicação de controle da qualidade na produção. 
Para que a racionalização das técnicas executivas, que são um conjunto de operações empregadas pela mão-de-obra para executar parte de uma edificação, intervenham na construtibilidade, é preciso que as especificações sejam revistas em detalhes por clientes, projetistas e construtores, buscando simplificar as operações de construção.

A elaboração de procedimentos de execução, ou procedimentos operacionais, tem como objetivo procurar aumentar a eficiência da execução das atividades. Devem ser elaborados com detalhes, de forma clara e compreensível, para que se evitem equívocos por parte da mão-de-obra. Estes documentos devem estar facilmente disponíveis a todos os envolvidos no processo, devem estar afixados em cartilhas ou manuais de procedimentos, presentes nos canteiros de obra, assim como nos escritórios.

É importante ressaltar que haver coerência entre as medidas adotadas e a política da empresa já representa um grande avanço para a racionalização.

Algumas diretrizes a serem seguidas para a racionalização das técnicas executivas em alvenaria estrutural se encontram discriminadas baseadas em estudos desenvolvidos por FRANCO \& AGOPYAN (1994), HEINECK \& ANDRADE (1994) e OLIVEIRA (1994). Dentre elas ressaltam-se:

- simplificar as atividades ligadas à execução, através da redução do número de operações, no que concerne a tarefas, equipamentos e materiais;

- executar uma atividade coerentemente, em termos de racionalização e nível tecnológico, com o projeto do edifício;

- procurar desenvolver as atividades sem interrupções delas e dos demais serviços;

- garantir adequação ao acesso e aos espaços de trabalho, como por exemplo, a realização dos serviços de pavimentação de térreos, a 


\section{ASPECTOS GERAIS
DEPARTAMENTO DE ENGENHARIA DE ESTRUTURAS -EESC/USP}

construção de escadas e plataformas de acesso definitivas, o mais cedo possível;

- proporcionar condições adequadas ao transporte e ao manuseio pela mão-de-obra especializada, de peças, componentes e ferramentas no que se refere ao peso e ao formato;

- cuidar para que não ocorram possíveis interferências entre a atividade executada e as demais atividades ligadas a ela;

- preconizar a pré-moldagem e a repetição de atividades na forma de linhas de produção mais organizadas, tanto no canteiro, como fora dele;

- empregar procedimentos coerentes com o nível de profissionalização e treinamento dos operários, e

- padronizar as tarefas para um mesmo sistema, visando à simplificação das atividades, como por exemplo, ter uma única forma de executar a alvenaria para todo o edifício.

A aplicação das diretrizes de racionalização em processos construtivos em alvenaria estrutural, por uma equipe de pesquisadores do $\mathrm{CPqDCC}^{1}$, em parceria com empresas privadas, possibilitou o desenvolvimento de processos com alto nível organizacional, e como resultado, a redução dos desperdícios e custos. As conclusões publicadas por FRANCO \& AGOPYAN (1994) foram baseadas em levantamentos de dados de produtividade da mão-de-obra para a execução de alvenaria estrutural não armada. O valor de produtividade da mão-de-obra obtido com o processo racionalizado, equivale a 0,82 homem hora por metro quadrado $\left(\mathrm{Hh} / \mathrm{m}^{2}\right)$ e é comparado a $1,60 \mathrm{Hh} / \mathrm{m}^{2}$, segundo Tabelas de Composição de Preços para Orçamento.

${ }^{1}$ Centro de Pesquisa e Desenvolvimento em Construção Civil da Escola Politécnica da Universidade de São Paulo. 
No entanto, deve-se ter em mente que, para atingir um alto grau de racionalização, as diretrizes precisam ser concebidas de maneira global, com ações abrangentes e que atinjam todas as pessoas envolvidas no processo construtivo. Para que haja o entendimento destes conceitos, mudanças da postura de "como resolver os problemas" são necessárias; caso contrário, encontrar-se-ão barreiras na implantação de processos racionalizados.

Em sua tese de doutorado, FRANCO (1992) defende a racionalização como "um bom caminho para fazer evoluir os processos construtivos, pois numa situação como a que atravessa o setor construtivo nos últimos anos, o ânimo para grandes investimentos e a ousadia para grandes mudanças são cada vez menores; portanto, as soluções devem contar mais com "investimento intelectual" do que com investimentos financeiros".

Nesse contexto, este trabalho proporá algumas soluções para aumentar o nível de racionalização de edifícios em alvenaria estrutural, com enfoque voltado à fase de desenvolvimento do projeto, porém, sempre analisando as viabilidades de implantação das soluções racionalizadas na fase de produção. Estas soluções compreendem o emprego de elementos pré-moldados, muitos dos quais já vêm sendo aplicados com eficiência comprovada por empresas do setor.

\subsection{Os Pré-moldados e o Aumento da Produtividade}

A racionalização construtiva, discutida no item 2.2 , caracteriza-se pela introdução de alterações que têm por objetivo um melhor aproveitamento dos recursos disponíveis em todas as fases dos empreendimentos, sem uma mudança radical na base tecnológica. Embora apresente uma definição clara, torna-se difícil encontrar um parâmetro para quantificar "o grau ou nível de racionalização". À primeira vista, uma possibilidade é a utilização do conceito de produtividade como proposto por FRANCO (1992).

Estudos sobre aumento de produtividade concluem que o efeito aprendizagem, efeito continuidade e efeito concentração elevam consideravelmente 
a produtividade da mão-de-obra de um serviço. Estes efeitos partem do princípio de que um trabalho executado repetidas vezes, sem interrupções e em grandes quantidades resulta na experiência da mão-de-obra e conseqüentemente na melhoria do seu desempenho.

Segundo HEINECK (1991), "não basta que o canteiro seja repetitivo, há necessidade de que os operários desloquem-se sem interrupção de uma tarefa para outra; ainda mais, dentro da própria tarefa, não podem haver paradas devido a falta de materiais, falta de detalhamento construtivo, interferência com outras tarefas, desbalanceamento e falta de elementos na equipe de trabalho, ou ingerência de causas naturais como chuvas, etc".

Em concordância com estes princípios, os pré-moldados leves preenchem os requisitos para serem considerados instrumentos de melhoria da produtividade na execução da alvenaria estrutural.

Dados extraídos de MEDEIROS \& SABBATINI (1994) apontam que a adoção de alguns pré-moldados tem permitido incrementos significativos na produtividade dos pedreiros assentadores de blocos, representando um aumento de aproximadamente $30 \%$ na produtividade de execução das paredes estruturais.

Os elementos pré-moldados apresentam, segundo os autores, diversas vantagens técnico-econômicas que permitem otimizar tanto a execução da obra, como a qualidade do produto final, principalmente com a diminuição de desperdício de material na execução de detalhes de obra, anteriormente resolvidos de modo artesanal. Com o emprego de alguns pré-moldados, chegou-se à redução de $25 \%$ nos custos da alvenaria com a contribuição das peças para os acabamentos e arremates posteriores. 


\subsection{Padronização}

Uma das maneiras de se obterem ganhos de produtividade é a padronização.

Padronização é definida por ROSSO (1966) como "a aplicação de normas a um ciclo de produção ou a um setor industrial completo com objetivo de estabilizar o produto ou o processo de produção".

Segundo o mesmo autor, ela assume os critérios de simplificação, tipificação, unificação e permutação. É estabelecida para os componentes em concordância com fabricantes e consumidores, de forma a permitir a substituição de um produto por outro de procedência diferente, mas com características idênticas, e nos ciclos produtivos é estabelecida por equipes técnicas aptas a determinarem a melhor maneira de se executar uma tarefa.

Os instrumentos para garantir a padronização é a elaboração de normas e manuais de procedimentos.

No setor de Construção Civil, um dos documentos mais importantes para a padronização dos componentes é o das normas de coordenação modular. No Brasil, a série de normas da ABNT sobre este tema é vasta, porém desatualizada, o que faz com que não seja seguida.

As conseqüências disso são tragicamente percebidas pela incompatibilidade entre as dimensões dos diversos componentes da construção, levando a quebras e conseqüentemente a perdas.

As construtoras, para minimizar este problema nacional, acabam por adaptar procedimentos executivos que compatibilizam as dimensões dos componentes existentes no mercado com o processo construtivo adotado. 


\subsection{Organização do Canteiro de Obra}

Atualmente, o maior desafio da economia é produzir mais com menor custo e em menos tempo, sempre visando à qualidade e um dos pontos críticos que afeta a produção é o ambiente de trabalho.

$\mathrm{Na}$ Construção Civil, a problemática do ambiente de trabalho torna-se mais acentuada, pois a fábrica se movimenta e não o produto, o edifício; sem contar com a elevada rotatividade da mão-de-obra que dificulta o planejamento das áreas de vivência.

Na opinião de SOUZA (2000), "não há sentido em se falar em qualidade na obra ou produtividade no processo construtivo quando não se tem planejado o local onde os serviços da construção acontecem".

Portanto, o canteiro de obra deve ser organizado de forma a otimizar, com segurança, o fluxo de suprimentos e de pessoas e, conseqüentemente, o fluxograma da produção.

O investimento no planejamento e elaboração de um canteiro de obra trará resultados positivos para a empresa, tanto no sentido quantitativo, como qualitativo. A correta estocagem de materiais e componentes reduzirá as perdas, a determinação de linhas de fluxo afetará a produtividade e a melhoria das condições das áreas de vivência dos trabalhadores será absorvida como forma de motivação. Todos estes fatores levam a uma economia.

Os elementos pré-moldados podem ser industrializados ou produzidos no próprio canteiro. Nas duas situações, é necessário que haja um canteiro organizado, com definições de espaços previamente destinados a estes elementos. 
No primeiro caso, é necessário espaço suficiente para estocagem do elemento até a sua utilização definitiva, com definições de fluxos de transporte otimizados.

A forma de transporte dos pré-moldados já deve estar definida previamente ao planejamento do canteiro, permitindo melhor interação entre o local de armazenamento e equipamentos de içamento. Caso o transporte dos pré-moldados seja feito manualmente pelos próprios operários da obra, a distância entre o estoque e o local de utilização deverá ser a mínima possível, com o que se reduz o risco de avarias nas peças e o risco de acidentes, assim como se diminui o esforço físico do operário.

É interessante também que o cronograma físico da obra esteja pronto, proporcionando a previsão dos quantitativos de materiais e de operários, bem como a previsão do início e duração do serviço. Pela análise do cronograma físico, conseguem-se melhores dados sobre o espaço destinado no canteiro, ao armazenamento dos pré-moldados, assim como o tempo necessário para a estocagem.

Já no caso da produção do elemento ocorrer no próprio canteiro, além da região de armazenamento e transporte, citadas anteriormente, é necessário o planejamento da área destinada às unidades produtivas.

Elementos pré-moldados leves podem ser produzidos em instalações mais simples e mais baratas, com pouca ou nenhuma mecanização, evitando-se grandes investimentos de capital.

Em muitas situações, na visão de HANAI \& EL DEBS (1993), "é possível empregar mão-de-obra não especializada. Entretanto, é conveniente introduzir o treinamento do pessoal, o controle de qualidade rigoroso e o incentivo à maior produtividade". 
Indicações sobre a produção de pré-moldados leves e organização do canteiro de obra são apresentadas com mais detalhes no capítulo 6.

\subsection{Viabilidade do Uso de Pré-Moldados Leves em Conjuntos Habitacionais}

Em 1999, no $3^{\circ}$. SEMINÁRIO DA INDÚSTRIA BRASILEIRA DA CONSTRUÇÃO, foi divulgado pelo Instituto Brasileiro de Geografia e Estatística (IBGE), o déficit habitacional brasileiro estimado em 5 milhões de unidades.

O Sistema Financeiro da Habitação (SFH), originado na década de 70, teve como objetivo manter financiamentos para a aquisição da casa própria pelas famílias de renda baixa e média baixa; porém, com as várias mudanças da política econômica do país, houve a descapitalização do SFH e a redução brusca dos investimentos destinados à habitação popular.

Com a desarticulação do SFH, a construção de grandes conjuntos habitacionais por processos industrializados de ciclo fechado e com tecnologias inovadoras tornou-se economicamente inviável.

Devem ser pensadas em alternativas mais econômicas, eficazes e adequadas aos países com menos recursos, com uso de técnicas de pré-fabricação, novos materiais, produtos e processos construtivos racionalizados e desenvolvidos para este tipo de intervenção.

Exemplos de intervenção com grande sucesso são as construções em regime de mutirão. Num programa chamado de mutirão, as prefeituras oferecem terra e materiais básicos, enquanto o próprio povo constrói a casa numa realização comunitária, convertendo o empreendimento em uma escola de capacitação profissional. 
A alvenaria estrutural surge como uma das alternativas de processo construtivo que atende aos requisitos descritos acima, pois é composta de elementos com dimensões e peso compatíveis ao esforço humano e com técnicas de execução simples, de fácil aprendizado e bem difundidas.

Também é consenso entre os construtores que a economia obtida ao se construir um edifício em alvenaria estrutural, com até 10 pavimentos sem transição em pilotis, pode chegar a $20 \%$ ou a $30 \%$, comparado ao mesmo edifício executado no sistema tradicional (AKASAKI, 1995).

Os elementos pré-moldados leves associados à alvenaria estrutural formam um conjunto harmônico e compatível com o regime de construção em mutirão. Estes elementos caracterizam-se por baixa massa unitária, que proporcionam transporte e montagem manual, dispensando-se equipamentos especiais de içamento.

A pré-moldagem proporciona aumento da produtividade em substituição a diversas etapas da obra, reduzindo o tempo de construção, o consumo de materiais e melhorando a qualidade do produto final.

\subsection{Elementos Propostos para Estudo}

Por meio de análise de projetos e de visita a obras de edifícios de alvenaria estrutural, fez-se um levantamento dos elementos pré-moldados leves usualmente utilizados e os quais mereceriam ser objeto de estudo deste trabalho.

Os aspectos considerados nesta análise referem-se à coordenação modular, facilidade de produção e montagem, viabilidade econômica e compatibilidade com o processo construtivo, que serão discutidos e comentados com mais afinco no desenvolvimento do trabalho. 
Os elementos pré-moldados selecionados foram: os blocos de concreto, as escadas, as vergas, os contramarcos e as peças de ajuste dimensional.

Para alguns elementos, será proposta a execução em argamassa armada devido a características como facilidade de conformação, obtenção de elementos leves, facilidade de obtenção da matéria-prima e assimilação de sua tecnologia pela mão-de-obra.

Os blocos de concreto constam entre os elementos selecionados, pois são considerados pré-moldados leves e desempenham função essencial no processo construtivo em alvenaria estrutural. Eles possuem modo de produção específico, dosagem e equipamentos apropriados.

Com a intenção de não alongar demasiadamente o trabalho e não tratar superficialmente o assunto, optou-se pela exclusão do modo de produção dos blocos. A coordenação modular será analisada, enfocando-se a modulação da alvenaria e as interferências com outros componentes da construção. Informações detalhadas sobre a produção de blocos de concreto podem ser obtidas em FERREIRA JUNIOR (1995) e MEDEIROS et alii (1994).

As lajes pré-fabricadas, em particular as lajes treliçadas, também se enquadrariam na proposta do trabalho sobre utilização de pré-moldados leves em edifícios de alvenaria estrutural; porém, a enorme diversidade do sistema de lajes, existente atualmente, faria com que o trabalho se tornasse muito extenso com a abordagem que o assunto merece. Acha-se conveniente então, que o assunto seja tratado em trabalho específico. Algumas dissertações sobre o dimensionamento e a execução de lajes treliçadas pré-moldadas foram e estão sendo desenvolvidas na Escola de Engenharia de São Carlos, dentre elas: BOCCHI JR (1995); DROPPA JR (1999) e MAGALHÃES (2001).

Os pré-moldados a serem estudados e sua utilização vantajosa estão na tabela 2.1. 
Tabela 2.1: Apresentação dos pré-moldados propostos para o estudo.

\begin{tabular}{|c|c|c|}
\hline $\begin{array}{c}\text { Pré- } \\
\text { moldado }\end{array}$ & Aplicação Vantajosa & Ilustração \\
\hline $\begin{array}{l}\text { Blocos de } \\
\text { concreto }\end{array}$ & $\begin{array}{l}\text { Constituem as paredes estruturais das } \\
\text { edificações em alvenaria estrutural. } \\
\text { Podem reduzir o custo de edificações } \\
\text { de até } 10 \text { pavimentos (sem transição) } \\
\text { em torno de } 20 \text { a } 40 \% \text {. }\end{array}$ & \\
\hline Escadas & $\begin{array}{l}\text { Minimizam os transtornos de execução } \\
\text { de escadas no local, com vantagens } \\
\text { quanto ao manuseio, compatibilidade } \\
\text { com a capacidade do ser humano, } \\
\text { rapidez e simplificação de execução. } \\
\text { As paredes estruturais suportam o } \\
\text { peso das escadas pré-moldadas. }\end{array}$ & \\
\hline Verga & $\begin{array}{l}\text { Além da função estrutural, também } \\
\text { promovem o ajuste dimensional } \\
\text { altimétrico das aberturas de portas. } \\
\text { Permitem o assentamento ininterrupto } \\
\text { dos blocos. }\end{array}$ & \\
\hline $\begin{array}{l}\text { Contra- } \\
\text { marcos }\end{array}$ & $\begin{array}{l}\text { Regulam o vão das aberturas, são } \\
\text { assentados durante a elevação da } \\
\text { alvenaria representando terminalidade } \\
\text { do serviço e melhoram o desempenho } \\
\text { de estanqueidade das esquadrias. }\end{array}$ & \\
\hline $\begin{array}{l}\text { Peças de } \\
\text { ajuste } \\
\text { dimensio- } \\
\text { nal }\end{array}$ & $\begin{array}{l}\text { Promovem a coordenação modular } \\
\text { entre os componentes com dimensões } \\
\text { incompatíveis, sem necessitar de } \\
\text { enchimentos e conseqüentes perdas } \\
\text { de materiais, racionalizando o } \\
\text { processo. }\end{array}$ & \\
\hline
\end{tabular}

Todos os elementos pré-moldados apresentados têm características que preconizam a racionalização do processo construtivo, visando à otimização do 
uso de recursos e à melhoria da qualidade, produtividade e à redução de custos, sem contudo, haver mudanças drásticas na base tecnológica do setor.

A pré-moldagem, de modo geral, implica em linhas de produção mais organizadas, com a repetição das atividades e os elementos pré-moldados acabam por simplificar a execução, eliminar retrabalhos e reduzir o número de etapas construtivas sem interferir na realização de outros serviços ou interrompê-los.

Alguns dos elementos mencionados na tabela 2.1, e que serão analisados com mais detalhes no decorrer do trabalho, foram resultado de um trabalho realizado na USP para uma construtora de grande porte, e com os quais se obteve grande sucesso em edifícios de alvenaria estrutural, como ilustrado nas figuras 2.1 e 2.2 .

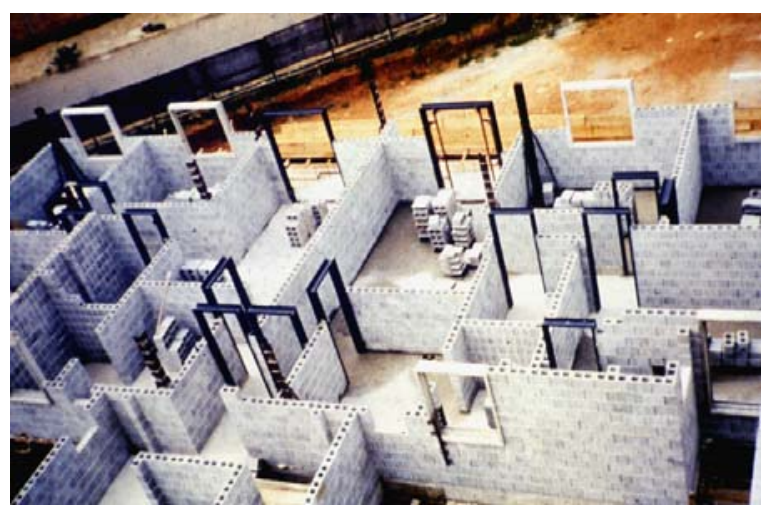

Figura 2.1: Vista superior de um edifício em alvenaria estrutural com incorporação de elementos pré-moldados leves (cortesia do Eng. Márcio S. Faria)

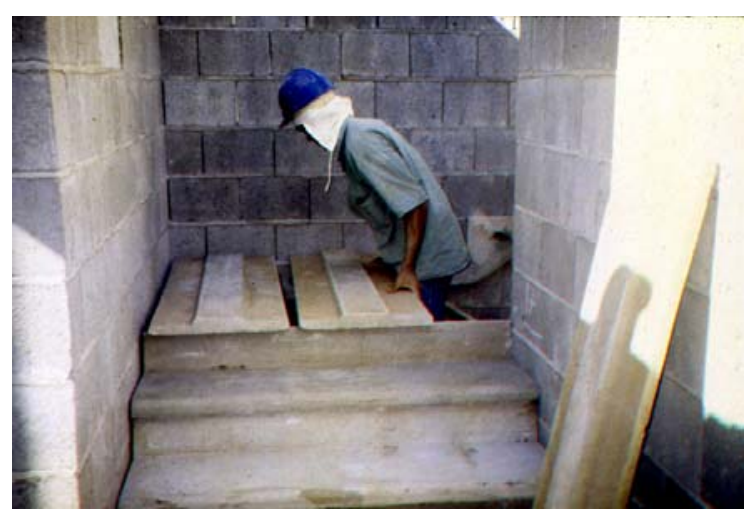

Figura 2.2: Execução de uma escada pré-moldada (cortesia do Eng. Marcio S. Faria) 


\title{
3. COORDENAÇÃO MODULAR
}

\author{
A coordenação modular é um instrumento destinado a organizar
} como unidades independentes, com os projetos arquitetônicos, tendo como objetivo principal a racionalização da construção, do projeto à execução.

É necessário, portanto, haver um sistema capaz de ordenar a construção desde o projeto e fabricação dos componentes até a execução da obra, visando a intercambialidade entre os componentes.

Neste trabalho serão propostos alguns elementos pré-moldados para serem utilizados em edifícios de alvenaria estrutural, que por sua vez, seguem uma modulação. Assim as dimensões dos elementos devem estar coordenadas modularmente com a alvenaria.

As vantagens obtidas através da coordenação modular são várias, dentre as quais :

simplificação da elaboração do projeto;

normalização dos componentes de construção;

otimização das dimensões com redução do número de formato dos componentes da construção;

diminuição de problemas de interface entre componentes e subsistemas;

padronização dos detalhes e precisão dimensional; 
racionalização e simplificação na execução da obra com a facilidade da montagem, e

redução de quebras dos materiais e, conseqüentemente, das perdas.

\subsection{Histórico}

O levantamento histórico apresentado por ROSSO (1966) aponta que os estudos pioneiros da coordenação modular voltados à Construção Civil datam de 1936 com a publicação de uma técnica de coordenação denominada "método modular cúbico", pelo americano Alfred Farewell Bemis. Na mesma época, estudos semelhantes eram desenvolvidos na Europa e desde então não cessaram.

Por todos os países preocupados com a padronização foram surgindo normas que estabeleciam critérios e tabelas com números para a construção coordenada modularmente.

Todos os trabalhos publicados possuíam caráter nacionalista, variando suas especificações conforme o país. Sentiu-se, então, a necessidade de uma padronização internacional e em 1953 a INTERNATIONAL STANDARD ORGANIZATION (ISO) forma uma comissão com objetivo de alcançar esta padronização. Também nesta época, a AGÊNCIA EUROPÉIA DE PRODUTIVIDADE (AEP) organizou um plano especial para o estudo da coordenação modular de caráter internacional.

No Brasil, a ASSOCIAÇÃO BRASILEIRA DE NORMAS TÉCNICAS, elaborou, por volta de 1950, a Norma Brasileira da Coordenação Modular da Construção (NBR 5706), conhecida como NB-25.

Em âmbito Pan-americano, a Comissão Pan-americana de Normas Técnicas (COPANT), promove estudos de normas complementares para que os países pan-americanos possam implantar a coordenação modular. O mesmo ocorre com os trabalhos da ISO em âmbito internacional.

Contudo, a existência das normas não garante o seu uso. EICKHOFF (1997) descreve as causas pelas quais as normas referentes à coordenação dimensional não são seguidas: "Segundo técnicos da ABNT, os 
fabricantes acreditam que seriam necessários grandes investimentos para adequar a sua produção para as dimensões normalizadas, os consumidores não têm organização para cobrar sua aplicação, e o poder público não define regras que a estimulem".

No Brasil, as publicações referentes a este tema estão desatualizadas. Justamente em uma época em que vigoram discussões sobre qualidade total na Construção Civil.

No entanto, este pensamento tende a mudar, estimulado por crescentes preocupações com qualidade e produtividade e pela citação das Normas Técnicas da ABNT no Código de Defesa do Consumidor.

Todas as publicações existentes no mundo só vêm comprovar que para se obter a racionalização da construção é importante haver coordenação modular.

\subsection{Conceitos que Influem na Coordenação Modular}

Para atingir aos objetivos propostos pela coordenação modular e aplicar eficientemente esta técnica, é necessário o conhecimento de alguns conceitos específicos apresentados pela Norma Brasileira de Coordenação Modular da Construção - ABNT (1977), NBR 5706.

A coordenação modular está estruturada em três princípios básicos:

sistema de referência;

módulo, e

ajuste modular.

\subsubsection{Sistema de Referência}

Segundo as definições da NBR 5706, o sistema de referência é formado por pontos, linhas e planos aos quais devem relacionar-se as medidas e posições dos componentes da construção.

Este sistema de referência é definido por planos paralelos, ortogonais dois a dois, constituindo o triedro axonométrico, em relação ao qual a posição de 
um ponto no espaço fica determinada por suas projeções como está mostrado na figura 3.1.

No sistema de referência, fica determinada a posição de cada componente da construção no espaço, permitindo assim sua conjugação racional.

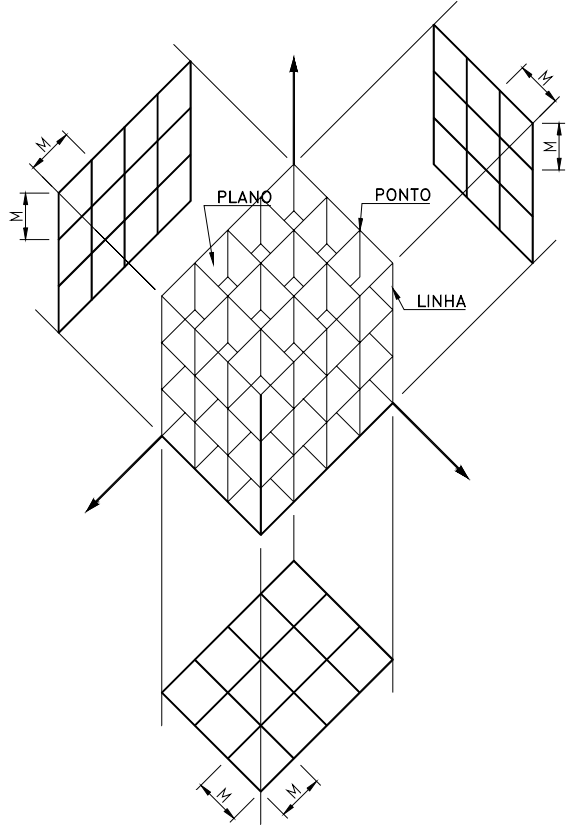

Figura 3.1: Triedro axonométrico e projeções que representam os quadriculados modulares de referência (BNH/IDEG, 1976)

Considerando-se que a representação gráfica dos projetos usualmente é feita em duas dimensões, a posição dos componentes da construção e suas dimensões no desenho ficam facilmente determinadas.

\subsubsection{O Módulo}

O módulo é a unidade de medida padrão de referência. Ele representa o espaçamento entre os planos do sistema de referência ilustrado na figura 3.1.

A ABNT (1977), NBR 5706, define o módulo como a distância entre dois planos consecutivos do sistema que origina o reticulado espacial modular de referência.

ROSSO (1966), define o módulo como "a unidade de medida convencional adotada para estabelecer dimensões, proporções e ordenar a 
construção de elementos de um determinado organismo arquitetônico, passando a desempenhar a função de divisor comum a todas ou algumas dimensões dos elementos industrializados de forma a proporcionar condições para sua atividade e elasticidade de aproveitamento".

$\mathrm{Na}$ arquitetura clássica, o módulo (do latim módulus, diminutivo de modus que significa medida) já era adotado pelos etruscos que desenvolveram um sistema de proporções baseado no diâmetro inferior da coluna. Na arquitetura japonesa, o módulo era função das dimensões do tatami, esteira retangular de palha que reveste os pisos de todos os ambientes.

Porém, muito mais do que efeitos arquitetônicos e estéticos, atualmente, o módulo representa uma forma de padronização e racionalização do projeto, provocando um efeito organizador. ROMANO (1993) acrescenta ao dizer que "um módulo mal pensado pode resultar em verdadeiros desastres, em impasses de projeto, numa enorme quantidade de variantes para o mesmo componente, numa infinidade de casos atípicos. Tudo isto encarece e dificulta a aplicação do sistema, podendo, conforme o caso, até provocar sua inviabilidade".

O espaço modular deve compreender a associação do componente e sua junta.

A junta é a distância prevista no projeto entre os extremos adjacentes de dois componentes.

\subsubsection{O Ajuste Modular}

O ajuste modular (aM) irá compatibilizar a relação entre os componentes com o sistema de referência. Com ele é possível relacionar a medida de projeto $(\mathrm{Mp})$ à medida modular $(\mathrm{nM})$.

\section{$\mathrm{aM}=\mathrm{nM}-\mathrm{Mp}$}

\begin{tabular}{l|l}
\hline Medida modular (nM) & $\begin{array}{l}\text { Medida referente a um módulo ou a um múltiplo inteiro } \\
\text { do módulo. }\end{array}$ \\
\hline Medida de projeto $(\mathrm{Mp})$ & Medida do componente da construção. \\
\hline
\end{tabular}


Para melhor compreensão destes conceitos sugere-se o entendimento da figura 3.2 que representa a relação de uma esquadria com a alvenaria.

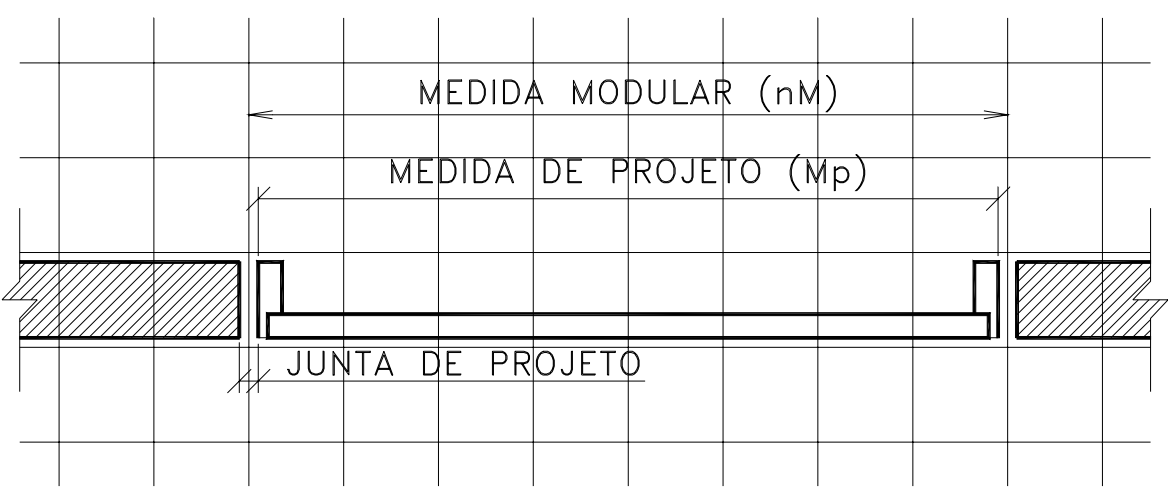

Figura 3.2: Exemplo da medida modular, medida de projeto e junta de projeto para uma esquadria (BNH/IDEG, 1976)

O ajuste modular deverá ser determinado considerando-se as juntas mínimas e máximas admissíveis em conjunto com as tolerâncias de fabricação mínimas e máximas dos componentes.

\subsection{Modulação na Alvenaria Estrutural}

Quando o processo construtivo é em alvenaria estrutural, a coordenação modular torna-se etapa imprescindível de projeto. Os cuidados com relação à modulação devem ser tomados para garantir a racionalização da construção e permitir o alto índice de produtividade que este processo é capaz de atingir, além de reduzir a quantidade de ajustes e a quebra de blocos.

Uma das primeiras etapas a ser efetuada durante o projeto estrutural é a modulação das paredes, baseada nas dimensões arquitetônicas e na definição do tipo de bloco adotado.

Atualmente no Brasil, os tipos de blocos destinados à construção em alvenaria estrutural que mais se destacam dividem-se em blocos de concreto e blocos cerâmicos, porém grande parte dos construtores optam por blocos de concreto. Esta escolha reside no fato de haver normas brasileiras para o cálculo e execução com este tipo de bloco, além de os blocos de concreto atingirem resistências maiores, sendo, portanto, adequados aos edifícios mais altos. 
O bloco cerâmico, apesar de ser usado em escala menor, apresenta algumas vantagens interessantes em relação ao bloco de concreto, como o menor peso e conseqüentemente a facilidade de manuseio em obra, além de apresentarem melhor aspecto estético.

No entanto, o fator decisivo de escolha acaba sendo o custo do produto. Isto implica em condições de fornecimento no mercado, facilidade de obtenção do produto pelos construtores e custos com o transporte.

\subsubsection{Os Blocos}

Para a realização da modulação das paredes de alvenaria, inicialmente é necessário especificar as dimensões dos blocos modulares a qual determinará a medida do módulo.

Nas definições da ABNT (1994), NBR 6136, blocos modulares são aqueles com dimensões coordenadas para a execução de alvenarias modulares, isto é, alvenarias com dimensões múltiplas do módulo $\mathrm{M}=10 \mathrm{~cm}$. Dimensões reais são as dimensões de fabricação dos blocos (largura, altura e comprimento). As dimensões nominais (modulares) equivalem às dimensões reais acrescidas de $1 \mathrm{~cm}$, correspondentes à junta de argamassa, e o mínimo comprimento nominal dos blocos corresponde a $2 \mathrm{M}=20 \mathrm{~cm}$.

Os blocos modulares e submodulares devem atender às dimensões reais constatadas na ABNT (1994), NBR 6136, para blocos estruturais de concreto e ABNT (1992), NBR 7171, para os blocos cerâmicos, os quais se encontram divididos segundo sua largura padrão (20 ou $15 \mathrm{~cm}$ ), apresentadas nas tabelas 3.1 e 3.2 . 
Tabela 3.1: Dimensões reais dos blocos modulares e submodulares de concreto segundo a NBR 6136.

\begin{tabular}{|c|c|c|c|c|}
\hline \multirow{2}{*}{ Dimensão(cm) } & \multirow{2}{*}{ Designação } & \multicolumn{3}{|c|}{ Dimensões coordenadas (mm) } \\
\cline { 3 - 5 } & & Largura & Altura & Comprimento \\
\hline \multirow{2}{*}{20} & \multirow{2}{*}{$\mathrm{M}-20$} & 190 & 190 & 190 \\
\cline { 3 - 5 } & & 190 & 190 & 390 \\
\hline \multirow{2}{*}{15} & \multirow{2}{*}{$\mathrm{M}-15$} & 140 & 190 & 190 \\
\cline { 3 - 5 } & & 140 & 190 & 390 \\
\hline
\end{tabular}

OBS: A ABNT (1982), NBR 5712, ainda considera a dimensão de $90 \mathrm{~mm}$ para o comprimento e para a meia altura dos blocos modulares de concreto.

Tabela 3.2: Dimensões reais dos blocos cerâmicos segundo a NBR 7171.

\begin{tabular}{|c|c|c|c|c|}
\hline Dimensão(cm) & Designação & \multicolumn{3}{|c|}{ Dimensões coordenadas (mm) } \\
\cline { 3 - 5 } & & Largura & Altura & Comprimento \\
\hline \multirow{3}{*}{20} & \multirow{3}{*}{$\mathrm{M}-20$} & 190 & 190 & 190 \\
\cline { 3 - 5 } & & 190 & 190 & 240 \\
\cline { 3 - 5 } & & 190 & 190 & 290 \\
\cline { 3 - 5 } & \multirow{3}{*}{15} & 190 & 190 & 390 \\
\hline \multirow{3}{*}{15} & 140 & 190 & 190 \\
\cline { 3 - 5 } & \multirow{3}{*}{$\mathrm{N}-15$} & 140 & 190 & 240 \\
\cline { 3 - 5 } & & 140 & 190 & 290 \\
\cline { 3 - 5 } & & 140 & 190 & 390 \\
\hline
\end{tabular}

Ressalta-se que a denominação da ABNT de M-15 e M-20 para o bloco está relacionada com a medida modular da espessura e não do comprimento do bloco, como freqüentemente é usado no meio técnico. Neste trabalho, a notação adotada será a mesma da norma para a espessura e BL-15 para blocos com comprimento múltiplo de $15 \mathrm{~cm}$ e BL-20 para múltiplo de $20 \mathrm{~cm}$.

Um levantamento das dimensões dos blocos fornecidos no mercado, no estado de São Paulo, foi feito e é apresentado neste trabalho nas tabelas 3.3 e 3.4. Os dados deste levantamento contemplam apenas os blocos M-15 e M-20, pois a ABNT (1989), NBR 10837, fixa tanto para alvenaria armada como para alvenaria não-armada, espessura mínima de parede de $14 \mathrm{~cm}$. 
Tabela 3.3: Dimensões usuais de mercado para blocos de concreto M-15 e M-20.

\begin{tabular}{|c|c|c|c|c|}
\hline \multirow{2}{*}{$\begin{array}{c}\text { Dimensão } \\
(\mathbf{c m})\end{array}$} & \multirow{2}{*}{ Designação } & \multicolumn{3}{|c|}{ Dimensões coordenadas (mm) } \\
\cline { 3 - 5 } & & Largura & Altura & Comprimento \\
\hline \multirow{2}{*}{20} & \multirow{2}{*}{$\mathrm{M}-20$} & 190 & 190 & 190 \\
\hline \multirow{3}{*}{15} & & 190 & 190 & 390 \\
\hline \multirow{3}{*}{$\mathrm{*}$} & 140 & 190 & 190 \\
\cline { 3 - 5 } & \multirow{3}{*}{$\mathrm{M}-15$} & 140 & 190 & 290 \\
\cline { 3 - 5 } & & 140 & 190 & 340 \\
\cline { 3 - 5 } & & 140 & 190 & 390 \\
\cline { 3 - 5 } & & 140 & 190 & 440 \\
\cline { 3 - 5 } & & 140 & 190 & 540 \\
\hline
\end{tabular}

Tabela 3.4: Dimensões usuais de mercado para blocos cerâmicos M -15 e M-20.

\begin{tabular}{|c|c|c|c|c|}
\hline \multirow{2}{*}{$\begin{array}{c}\text { Dimensão } \\
\text { (cm) }\end{array}$} & \multirow{2}{*}{ Designação } & \multicolumn{3}{|c|}{ Dimensões coordenadas (mm) } \\
\cline { 3 - 5 } & & Largura & Altura & Comprimento \\
\hline \multirow{2}{*}{20} & \multirow{2}{*}{$\mathrm{M}-20$} & 190 & 190 & 190 \\
\hline \multirow{3}{*}{15} & & 190 & 190 & 390 \\
\hline \multirow{3}{*}{$\mathrm{*}$} & 140 & 190 & 140 \\
\cline { 3 - 5 } & \multirow{3}{*}{$\mathrm{M}-15$} & 140 & 190 & 190 \\
\cline { 3 - 5 } & & 140 & 190 & 290 \\
\cline { 3 - 5 } & & 140 & 190 & 390 \\
\cline { 3 - 5 } & & 140 & 190 & 440 \\
\hline
\end{tabular}

Analisando-se as tabelas 3.3 e 3.4 e comparando-as com as tabelas 3.1 e 3.2, extraídas da ABNT (1994), NBR 6136, e ABNT (1992), NBR 7171, respectivamente, percebe-se a necessidade de atualização da norma brasileira em relação aos aspectos dimensionais dos blocos, pois o mercado consumidor começa a exigir produtos que facilitem e harmonizem o processo de modulação, como é o caso dos blocos de concreto M-15 de comprimento $290 \mathrm{~mm}$ e os blocos especiais de $340 \mathrm{~mm}, 440 \mathrm{~mm}$ e $540 \mathrm{~mm}$ de comprimento.

\subsubsection{As Juntas}

O espaço modular deve compreender a associação do componente e sua junta. No caso da alvenaria, este espaço é ocupado pelo bloco associado à espessura de uma junta de argamassa.

Conforme especificado pela ABNT (1985), NBR 8798, os cordões devem ter espessura tal que, após o assentamento dos blocos, as juntas 
resultantes tenham espessura de $10 \pm 3 \mathrm{~mm}$, proibindo-se calços de qualquer natureza.

O mau preenchimento da junta horizontal, segundo FRANCO (1987), pode representar uma diminuição de 30\% na resistência à compressão. A execução de juntas horizontais de 16 a $19 \mathrm{~mm}$ de espessura, também pode levar a uma queda de $30 \%$ na resistência. Baseado nesta afirmação, pode-se comprovar que a modulação na alvenaria deixa de ter apenas caráter dimensional e passa a ter também implicações estruturais.

Para facilitar a execução das juntas de argamassa, durante a elevação das paredes, aconselha-se a utilização de equipamentos desenvolvidos especificamente para esta finalidade, como a bisnaga de assentamento (figura 3.3), a meia-cana e a palheta.

FRANCO et alii (1991) descrevem o funcionamento do equipamento, iniciando pelo preenchimento da bolsa com argamassa por meio de uma colher de pedreiro e prosseguindo com a deposição do filete sobre o bloco por compressão e torção manual desta bolsa, obrigando a extrusão da argamassa pelo bico metálico. Consegue-se, normalmente, um filete com extensão de quatro blocos por operação, o que agiliza a execução da alvenaria.
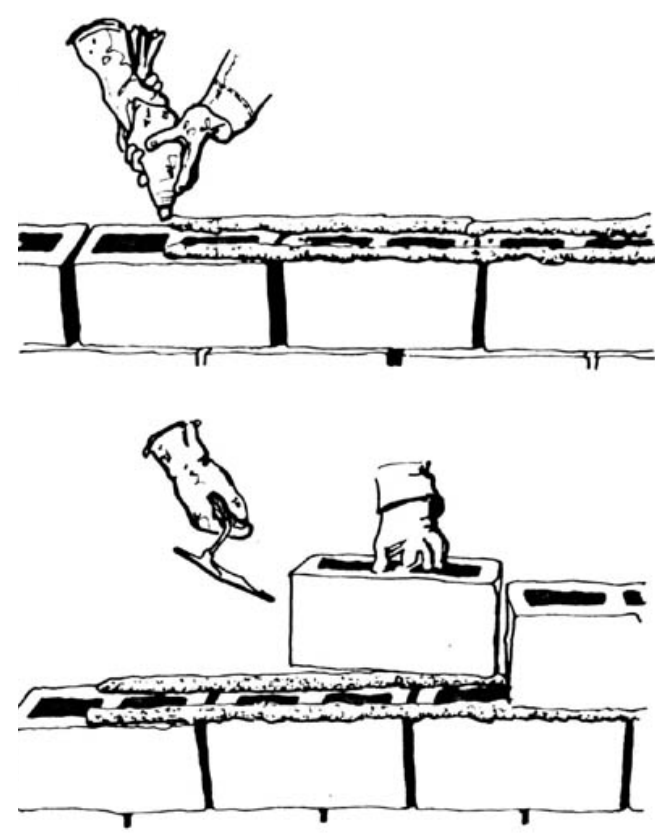

Figura 3.3: Bisnaga de assentamento (FRANCO et alii, 1991) 
Conforme especificado na ABNT (1985), NBR 8798, outras espessuras de juntas poderão estar previstas em projeto, desde que de eficiência comprovada em ensaios de desempenho.

Há projetistas que determinam o não preenchimento das juntas verticais da alvenaria. Esta determinação implica em fatores positivos e negativos.

Os aspectos positivos estão na redução do consumo de materiais juntamente com a maior velocidade de execução.

Como aspecto negativo está a redução em torno de 40\% de resistência ao cisalhamento (ROMAN \& SINHA, 1994). Esta redução traz a possibilidade de agravamento de problemas de fissuração na parede sob a laje de cobertura, por redução da resistência ao cisalhamento da parede (BASSO et alii, 1997).

A espessura máxima recomendada para o não preenchimento da junta vertical, deve ser de $0,5 \mathrm{~cm}$ para evitar problemas com o revestimento da parede. Assim sendo, a viabilidade deste procedimento ocorre quando se fizer uso de blocos com dimensões especiais compatíveis com juntas de $0,5 \mathrm{~cm}$.

\subsubsection{Os Ajustes}

O ajuste na alvenaria é a diferença entre a dimensão de projeto reservada para a colocação de um componente e a dimensão nominal do correspondente componente e depende do tipo de união e das superfícies dos materiais a unir.

No assentamento da alvenaria, o ajuste é positivo, pois a medida nominal dos componentes de construção é menor que o espaço reservado em projeto.

A incompatibilidade entre as dimensões dos componentes da edificação, muitas vezes, resulta em ajustes dimensionais de grandes espessuras e freqüentemente nos projetos não são especificadas soluções para o preenchimento destes ajustes, que acabam por serem executados de improviso na obra.

Um caso típico desta incompatibilidade são as dimensões das esquadrias com relação às aberturas dos vãos, como ilustrado na figura 3.4. 
Para contornar o impasse do enchimento, os engenheiros estão adotando elementos pré-moldados maciços de pequenas dimensões, conhecidos como "rapaduras" na linguagem coloquial, previstos em projeto e muitas vezes moldados no próprio local da obra, com função apenas de preencher os vazios existentes.

Algumas indústrias fabricantes de blocos já fornecem no mercado os elementos de ajustes ("rapadura"), denominando-os de blocos complementares.

\section{Elevação}

\section{Escala 1:50}
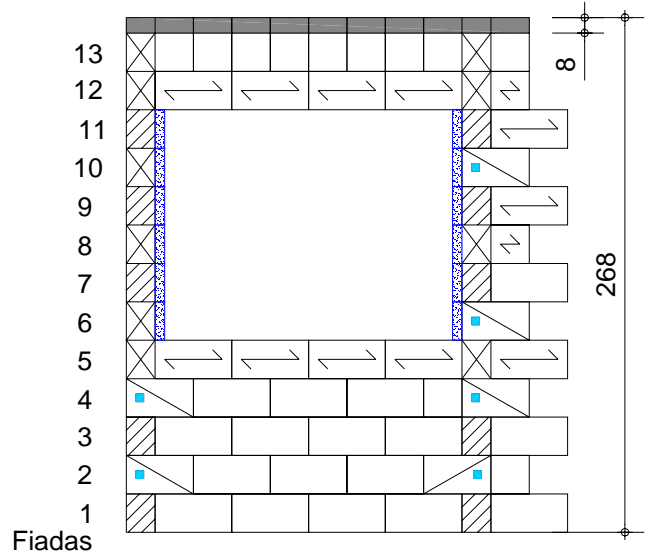

Vão da abertura (em osso): $161 \mathrm{~cm}$

Dimensão da esquadria adotada pela construtora: $150 \mathrm{~cm}$

Pré-moldados de $14 \times 4 \times 19$

Figura 3.4: Enchimento pré-moldado conhecido como "rapadura"

\subsection{Aplicação dos Conceitos de Coordenação Modular na Alvenaria Estrutural}

A modulação da alvenaria é o acerto das dimensões em planta e do pé direito da edificação, em função das dimensões dos blocos, de modo a se evitar cortes ou ajustes na execução das paredes.

Para iniciar o processo de modulação, parte-se da escolha das dimensões do bloco, tendo sempre em mente que a coincidência do módulo longitudinal do bloco com a sua espessura (largura) evita o uso de blocos especiais, os quais encarecem o custo da obra e aumentam o número de componentes utilizados. 
No caso das dimensões do projeto arquitetônico não serem modulares, quanto menor o módulo utilizado mais fácil será o ajuste necessário. Nesse sentido, as dimensões múltiplas de 15 cm são as mais adequadas (ACCETTI, 1998).

Portanto, em projetos modulares, as dimensões finais da edificação são de responsabilidade do profissional que realizará a modulação e não necessariamente do arquiteto que concebeu o projeto.

\subsubsection{Amarração}

Durante a modulação de uma planta deve-se procurar, sempre que possível, amarrar duas ou mais paredes que se encontram.

Amarração direta é o entrosamento alternado de fiadas. Ela permite a interação de paredes por existirem caminhos alternativos para o fluxo de cargas, que começa em uma parede e se espalha por paredes adjacentes. Tal fato pode ser resumido em um conceito: a tendência de uniformização de tensões que ocorre ao longo da altura do edifício. Essa tendência é altamente benéfica ao comportamento estrutural das paredes, pois significa que as mais carregadas servem-se das menos solicitadas para aliviarem os seus excessos (CORRÊA \& RAMALHO, 1994).
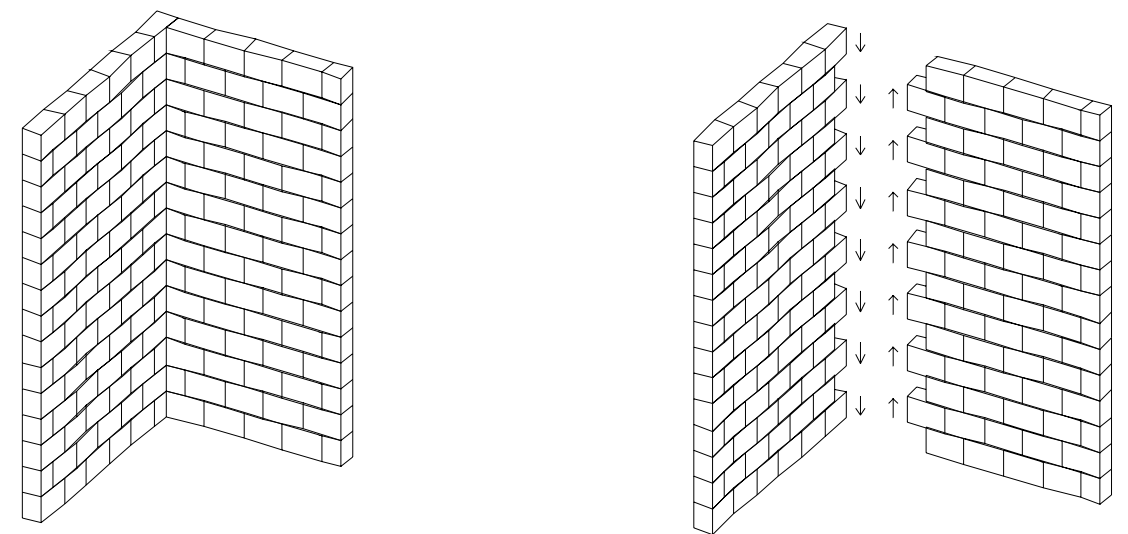

Figura 3.5: Interação entre paredes nos cantos (CORRÊA \& RAMALHO, 1996) ${ }^{1}$

1 CORRÊA, M.R.S.; RAMALHO, M.A. (1996). Alvenaria estrutural. São Carlos, EESCUSP (Notas de aula da disciplina "SET-606 - Alvenaria estrutural"). 
A consideração da interação leva a diferenças apreciáveis nas cargas das paredes, podendo afetar de maneira significativa a segurança e a economia, pois contribui na prevenção do colapso progressivo, melhora o aproveitamento da capacidade resistente das paredes e favorece o contraventamento nas paredes.

Amarração direta, esquematizada na figura 3.5, consiste na disposição dos blocos nas fiadas desde que 50\% deles penetre alternadamente na parede interceptada, enquanto que a amarração indireta é obtida com o auxílio de barras ou telas metálicas.

A amarração direta das paredes está intimamente ligada à modulação da alvenaria, pois relaciona a espessura do bloco com o seu comprimento.

O ideal é que a dimensão do comprimento do bloco seja múltipla da espessura, com isto evita-se o uso de blocos especiais e facilita-se a amarração das paredes. Entretanto, nem sempre esta multiplicidade ocorre. Neste caso, recorre-se a procedimentos alternativos para prover a alvenaria de amarração eficiente, como por exemplo, com emprego de blocos especiais, os quais não possuem dimensões normalizadas.

Um detalhe importante com relação à amarração das paredes consiste em evitar as juntas a prumo; desta forma, a uniformização do fluxo de tensões entre as paredes fica garantida, proporcionando um melhor aproveitamento da capacidade resistente.

\subsubsection{Exemplo de Modulação com Amarração Direta}

A partir da planta de arquitetura apresentada na figura 3.6, a amarração da alvenaria será analisada para alguns casos de modulação de parede com $15 \mathrm{~cm}$ de espessura (M-15), abordando-se as facilidades e desvantagens obtidas com uso de blocos especiais. 


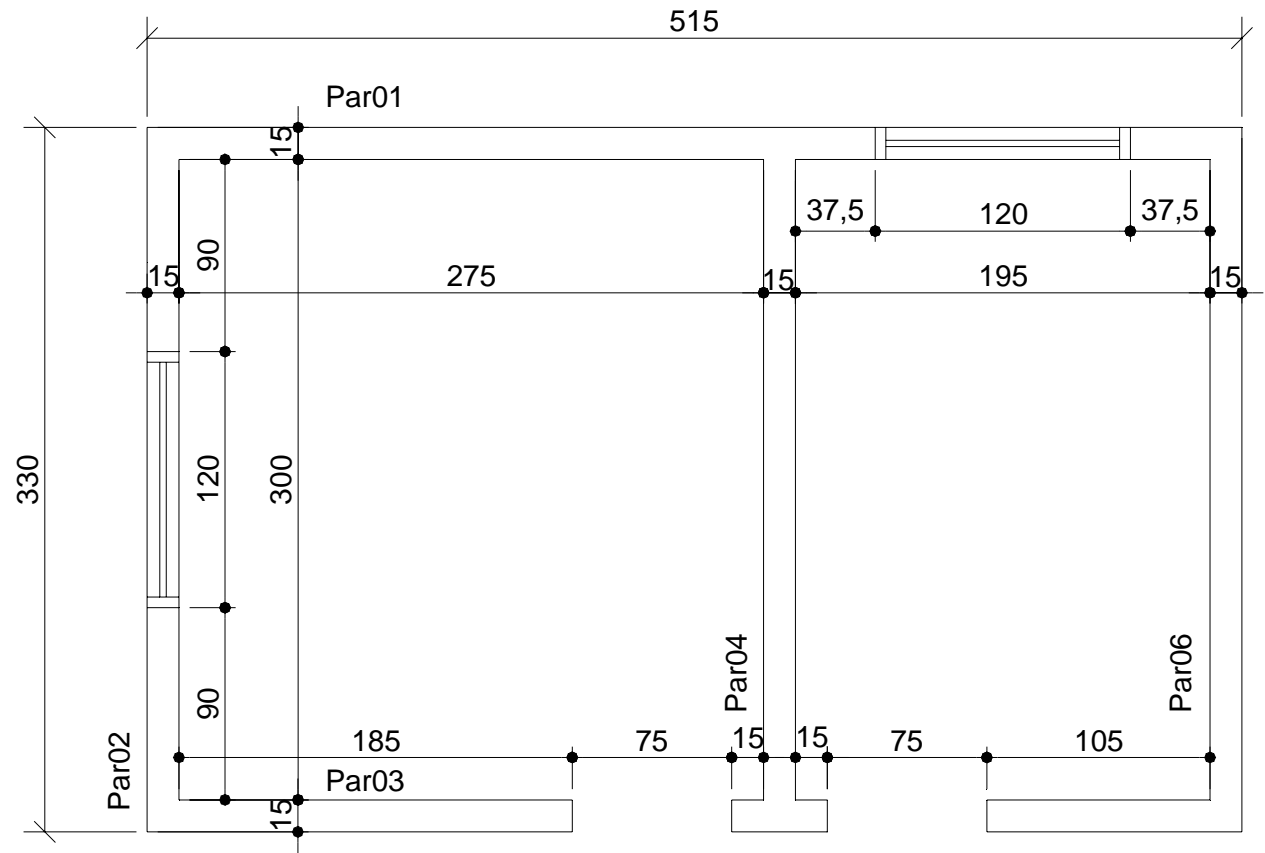

Arquitetura

Figura 3.6: Planta de arquitetura

A modulação da planta de arquitetura apresentada na figura 3.6, feita com blocos BL-15, está ilustrada na figura 3.7.

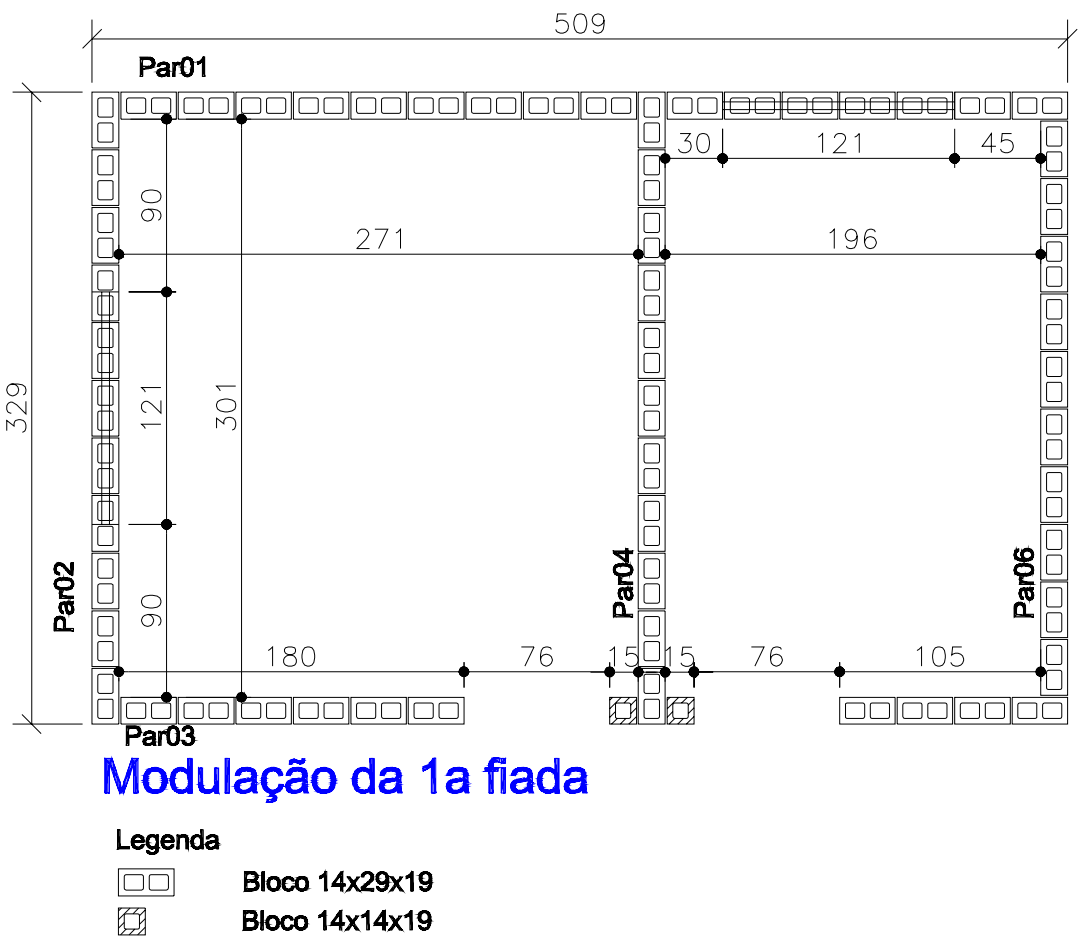

Figura 3.7: Planta de modulação $M-15$ da $1^{a}$ fiada com blocos BL-15 
Ressalta-se que houve necessidade de adequar as dimensões arquitetônicas (não modulares) às dimensões do módulo de $15 \mathrm{~cm}$. Como conseqüência desta adequação está a redução de $6 \mathrm{~cm}$ do comprimento horizontal que passou de $515 \mathrm{~cm}$ para $509 \mathrm{~cm}$.

Os cantos e as bordas são regiões que podem trazer conflitos, pois é onde deve haver o entrosamento alternado de fiadas que garantirá o perfeito funcionamento da amarração direta.

A amarração de canto das paredes com blocos BL-15, traz facilidades de projeto e de execução. A figura 3.8a demonstra tal situação.

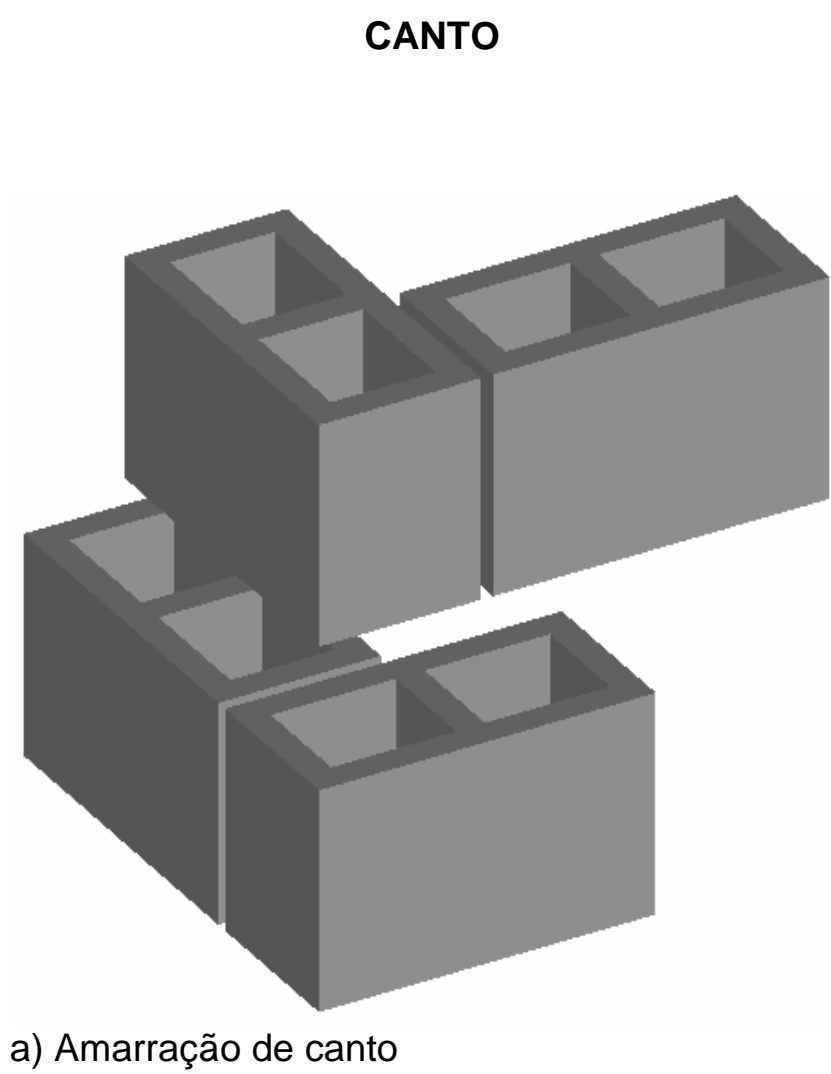

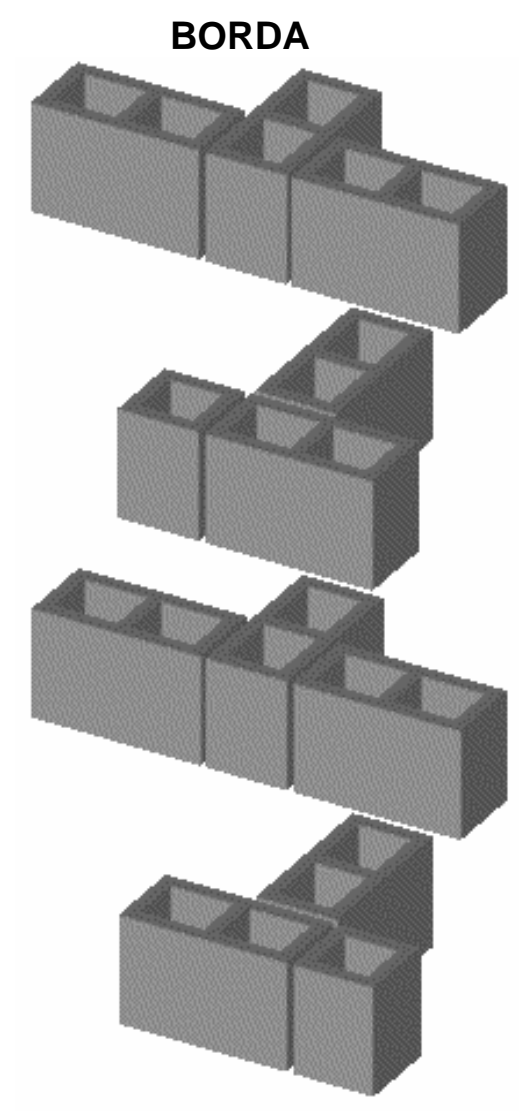

b) Amarração de borda com bloco em trânsito

Figura 3.8: Amarração de canto e de borda com modulação M-15 e blocos BL-15

Assim como nos cantos, as soluções de amarração para bordas quando se usa blocos BL-15, são viáveis sem uso de blocos especiais, como esquematizada na figura $3.8 \mathrm{~b}$. 
Este tipo de amarração é conhecido como amarração de bloco em trânsito, onde a junta a prumo não deve persistir por mais que três fiadas consecutivas.

Na figura 3.7, o encontro entre as paredes Par01 e Par04 é um exemplo de amarração de borda com bloco em trânsito. Recomenda-se que o detalhe de amarração com bloco em trânsito seja mostrado até a quarta fiada.

Apesar da possibilidade da não utilização de blocos especiais para a amarração das paredes de blocos BL-15, o seu uso otimiza a execução das paredes por simplificar o processo, contando apenas com duas fiadas diferentes e não quatro. O bloco necessário para esta amarração é o bloco de $45 \mathrm{~cm}$ de comprimento modular, conhecido como bloco e meio. O esquema ilustrativo de assentamento dos blocos se encontra na figura 3.9.

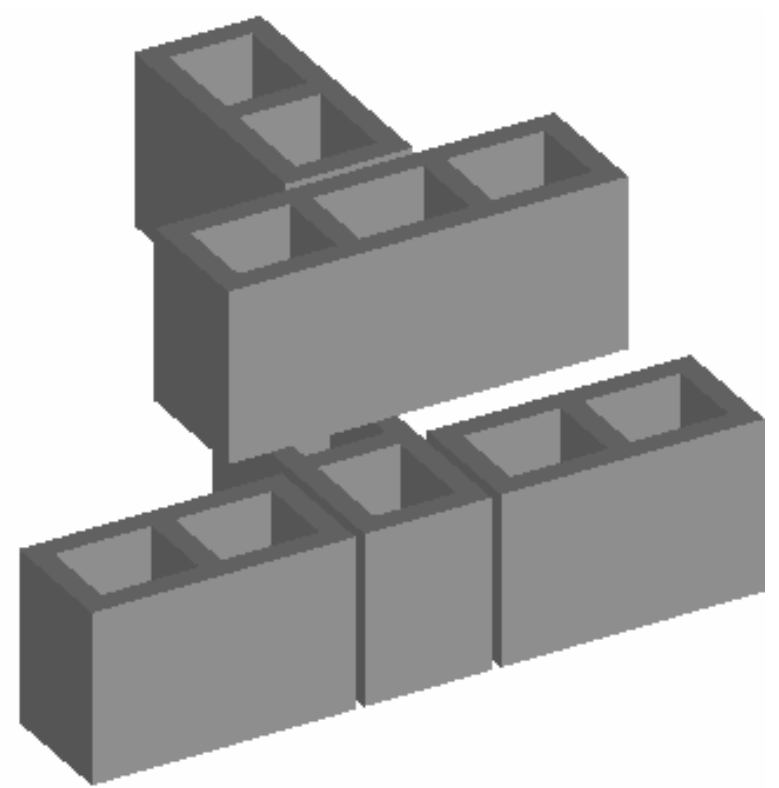

Figura 3.9: Amarração M-15 de borda com blocos BL-15 e com blocos especiais de $45 \mathrm{~cm}$ de comprimento modular

Na figura 3.10, será mostrada a mesma modulação da figura 3.7, com blocos BL-15, porém com auxílio do bloco especial de $35 \mathrm{~cm}$ de comprimento modular. 


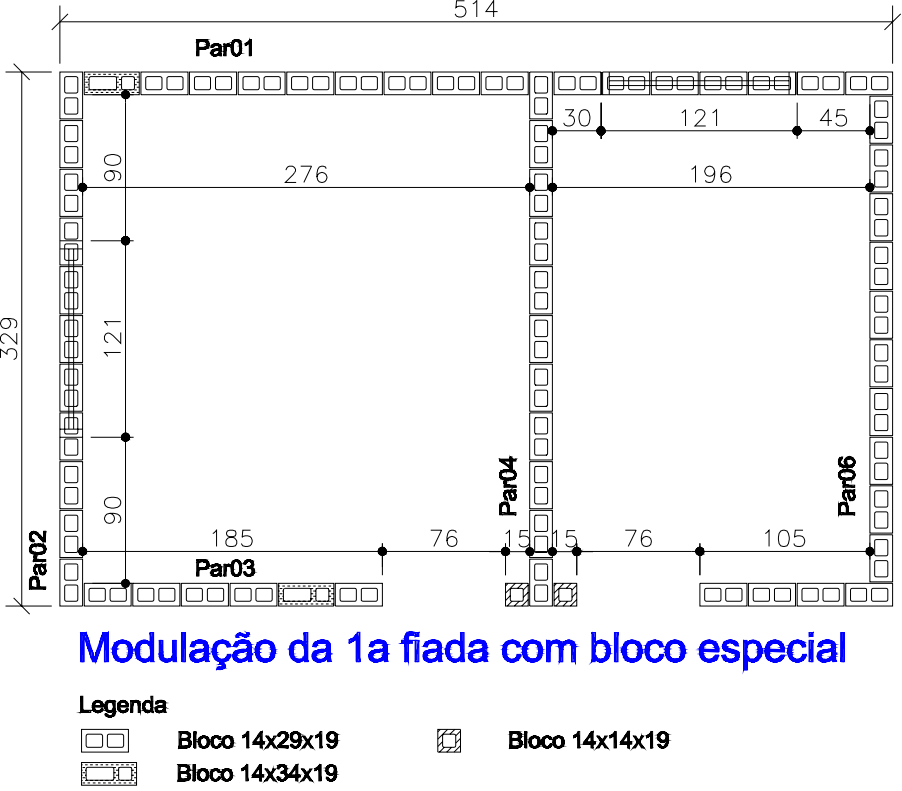

Figura 3.10: Modulação M-15 da $1^{\mathrm{a}}$ fiada de blocos BL-15 com emprego do bloco especial de $35 \mathrm{~cm}$ de comprimento modular

Quando é feito uso do bloco especial de $35 \mathrm{~cm}$ de comprimento modular, as medidas finais após a modulação se assemelham às medidas da planta arquitetônica. Este bloco proporciona maior versatilidade dimensional; a variação dimensional que antes era apenas de $15 \mathrm{~cm}$, passa agora a $5 \mathrm{~cm}$.

Cuidados devem ser tomados quanto à modulação da $2^{\mathrm{a}}$ fiada para que os septos intermediários do bloco especial de $35 \mathrm{~cm}$ sejam coincidentes, como é ilustrado na figura 3.11.

A adoção do bloco especial de $35 \mathrm{~cm}$ de comprimento modular deverá ser atentamente discutida, pois ao mesmo tempo proporciona vantagens e desvantagens. Como vantagem está a versatilidade que o bloco traz à modulação da alvenaria e como desvantagem está a adoção de um bloco diferente e de maior custo na obra, o qual requer cuidados especiais na etapa de execução, de forma que os espaços vazios de mesma dimensão entre os septos sejam assentados coincidentemente; também não são encontrados no mercado blocos canaleta de $34 \mathrm{~cm}$ de comprimento o que, fatalmente, acarretará em enchimentos localizados em vergas, contravergas e cintas. 


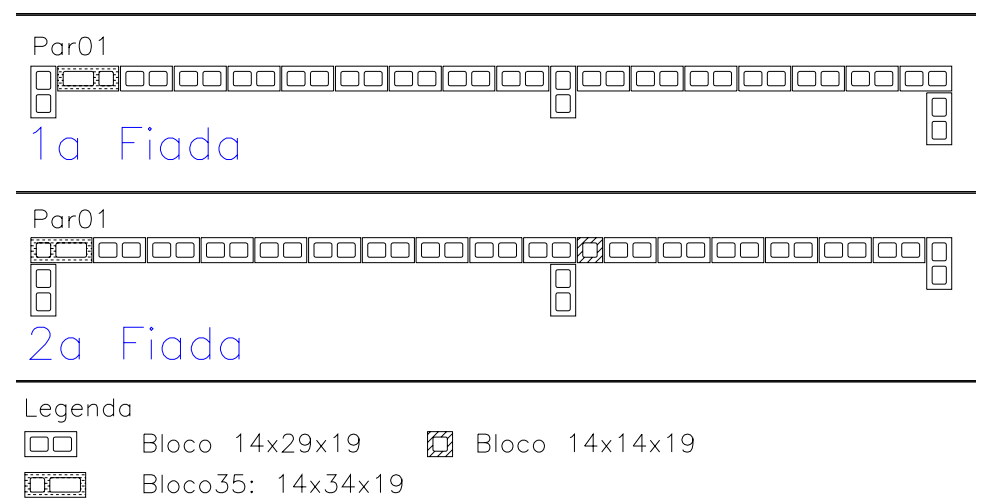

Figura 3.11: Modulação M-15 de $1^{\mathrm{a}}$ e $2^{\mathrm{a}}$ fiada da Parede Par01 com auxílio do bloco especial de $35 \mathrm{~cm}$ de comprimento modular

Apesar de não se recomendar o uso de blocos de dimensões que não tenham multiplicidade entre a espessura e o comprimento, muitos construtores, na pretensão de economizar e pela facilidade em adquirir o produto no mercado, acabam optando pela modulação M-15, com blocos BL-20. Desta forma, é apresentada nas figuras 3.12 e 3.13, a modulação para blocos BL-20.

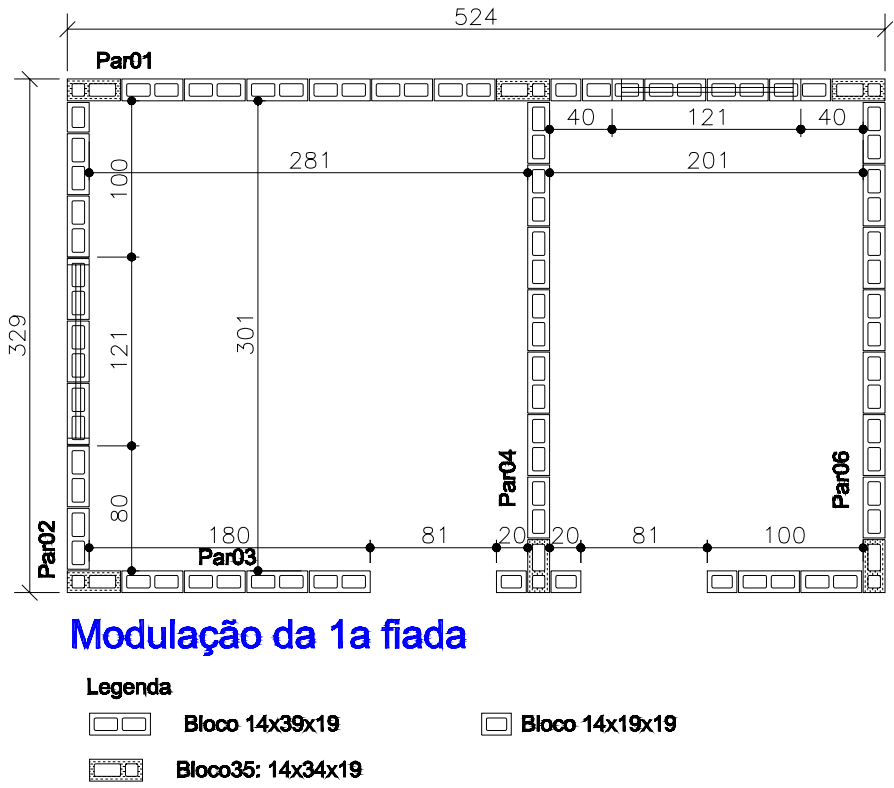

Figura 3.12: Modulação M-15 da $1^{\mathrm{a}}$ fiada de blocos BL-20 


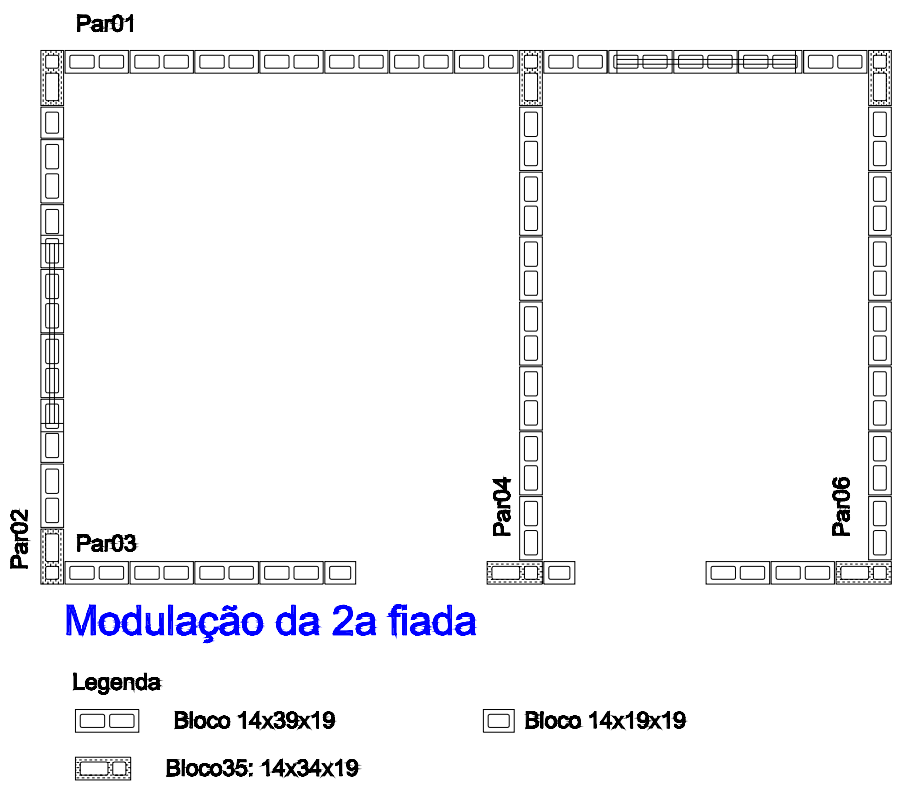

Figura 3.13: Modulação M-15 da $2^{\mathrm{a}}$ fiada de blocos BL-20

A amarração direta das paredes nos cantos e nas bordas nas figuras 3.12 e 3.13, só foi viável com uso do bloco especial de $35 \mathrm{~cm}$.

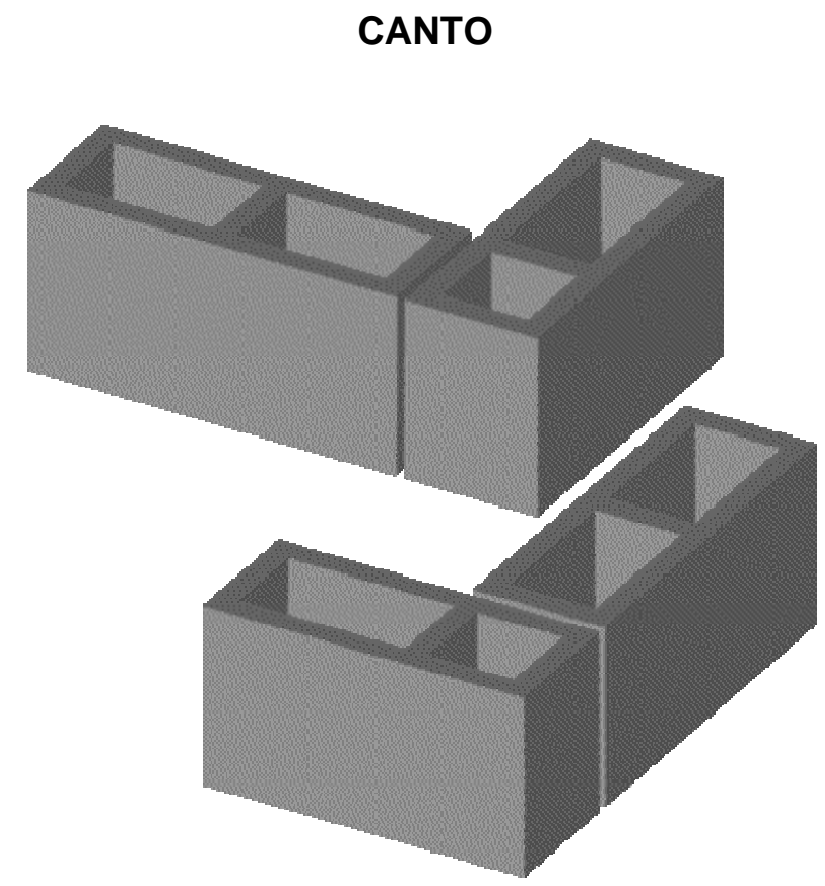

a) Amarração de canto
BORDA

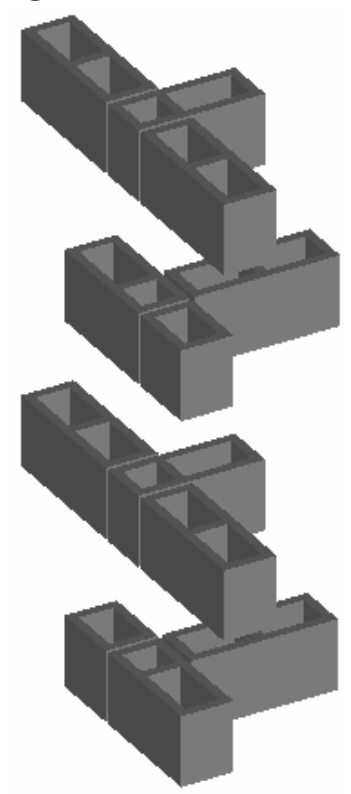

b) Amarração de borda com bloco em trânsito

Figura 3.14: Amarração (M-15) de canto e borda com blocos BL-20 e bloco especial de $35 \mathrm{~cm}$ de comprimento modular 
O bloco especial de $34 \mathrm{~cm}$ de comprimento substitui o bloco de $39 \mathrm{~cm}$ com grande eficiência, pois garante que os espaços vazios entre os septos estejam livres para a operação de grauteamento, fato este que não é possível quando se usa apenas blocos M-15 de $39 \mathrm{~cm}$.

Cuidados devem ser tomados quanto à modulação da $2^{\mathrm{a}}$ fiada para que os menores espaços vazios do bloco especial de $35 \mathrm{~cm}$ sejam coincidentes, como é ilustrado na figura 3.14a.

Nas amarrações de bordas, duas soluções são possíveis. A primeira delas com auxílio do bloco especial de $34 \mathrm{~cm}$, como mostrado na figura 3.14b. A junta a prumo não deve permanecer por mais que três fiadas consecutivas.

A segunda solução para amarração de borda (BL-20) refere-se ao emprego do bloco especial de $55 \mathrm{~cm}$ de comprimento modular (bloco e meio), ilustrado na figura 3.15. Porém, o bloco de $55 \mathrm{~cm}$ apresenta inconvenientes, como a dificuldade de encontrá-lo no mercado, e o peso maior, comparado aos outros blocos, que dificulta seu assentamento.

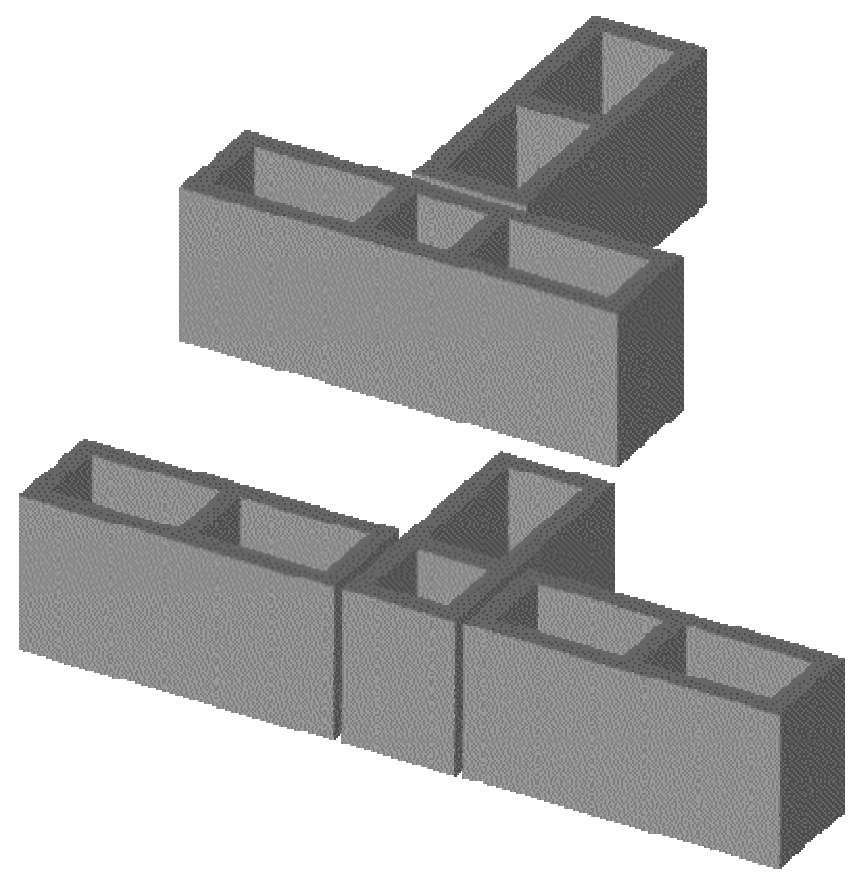

Figura 3.15: Amarração M-15 de borda com blocos BL-20 com bloco especial de $55 \mathrm{~cm}$ de comprimento modular 


\subsection{Modulação Altimétrica}

$\mathrm{Na}$ coordenação modular altimétrica, as alturas dos componentes de construção devem ser compatíveis e se relacionar com as alturas dos demais subsistemas. No caso da alvenaria, o componente que definirá a altura modular é o bloco.

A modulação altimétrica não exige detalhes de amarração. Neste caso, a determinação do pé direito fica definida pela altura dos blocos, pela espessura das juntas e pelas exigências das leis municipais.

O valor do módulo mais adequado para a modulação altimétrica é $20 \mathrm{~cm}$. Esta afirmação é baseada nos dados apresentados por ROSSO (1976), sobre as dimensões usuais dos aparelhos de habitação, como mostrado na tabela 3.5 .

Tabela 3.5: Tabela das alturas usuais dos aparelhos da edificação segundo ROSSO (1976).

\begin{tabular}{|l|c|}
\hline Aparelhos da habitação & $\begin{array}{c}\text { Alturas usuais } \\
\text { (cm) }\end{array}$ \\
\hline Bacia sanitária & 40 \\
\hline Mesa & $70-80$ \\
\hline Pia de banheiro & 80 \\
\hline Chuveiro & $200-220$ \\
\hline Banheira & 40 \\
\hline Armário embutido c/ espelho & 140 \\
\hline Peitoril de janela & $80,90,100$ \\
\hline Maçaneta & $100-110$ \\
\hline Pia de cozinha & $80-90$ \\
\hline
\end{tabular}

Analisando-se os dados da tabela 3.5, conclui-se que o módulo de $20 \mathrm{~cm}$ permite maior flexibilidade e a modulação altimétrica da alvenaria estrutural se enquadra nesses princípios, pois em geral é constituída por $19 \mathrm{~cm}$ de altura do bloco acrescida de $1 \mathrm{~cm}$ da junta de assentamento. 
A modulação altimétrica engloba as interferências com os demais componentes e subsistemas. As situações críticas de interferências estão nas regiões de interface com as paredes, como ocorre com as aberturas das esquadrias e as lajes.

As esquadrias devem ser compatíveis com os vãos das aberturas previstos nas paredes. Esta compatibilidade compreende as dimensões das esquadrias e o ajuste suficiente para o procedimento de assentamento.

Segundo a ABNT 1981 (NBR 5722 e NBR 5728), esquadrias modulares - portas e janelas com suas guarnições - são aquelas projetadas e executadas para ocupar vãos modulares. No entanto, a espessura destes componentes não precisa ser modular.

O estudo aprofundado sobre aspectos da compatibilidade entre as esquadrias e a modulação da alvenaria se encontra detalhado no capítulo 5, Aberturas.

As lajes constituem-se um subsistema inteiramente ligado às paredes estruturais, porém as diretrizes apontadas pela coordenação modular altimétrica nem sempre são seguidas na determinação da espessura da laje. Seria uma contradição pretender obter a coordenação modular entre os subsistemas e, no entanto, dimensionar exageradamente os pavimentos.

Para manter a modulação altimétrica da parede e ao mesmo tempo facilitar a execução das lajes e cintas de amarração, foram desenvolvidos blocos que proporcionam, conforme a espessura das lajes, perfeito entrosamento entre os subsistemas. Estes blocos são conhecidos como jota "J", jotão, canaleta e compensador, conforme ilustrações nas figuras 3.16 e 3.17 . 


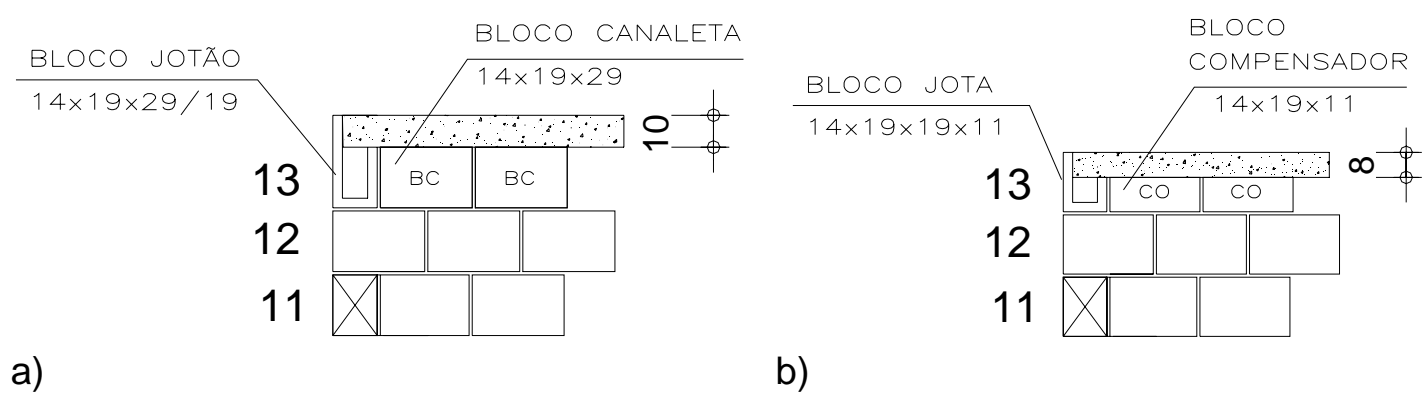

Figura 3.16: Esquema de elevação das paredes com blocos jotão e canaleta [a] e blocos jota e compensador [b]

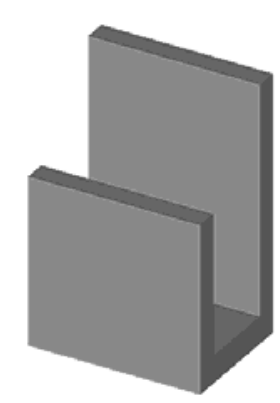

a) Bloco jota

Figura 3.17: Bloco jota e bloco compensador

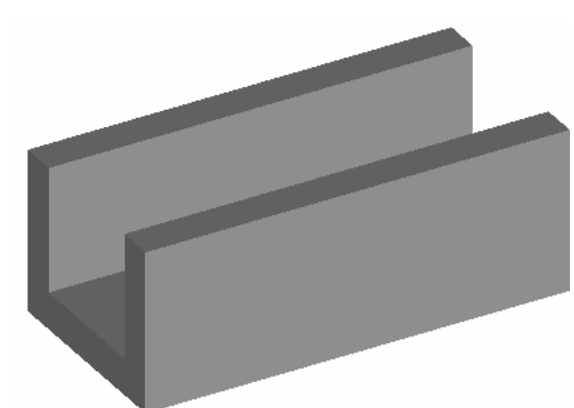

b) bloco compensador

Os blocos jota são usados na extremidade das paredes estruturais externas. O lado maior da parede do bloco, localizado na parte externa das paredes estruturais, garante a continuidade da modulação enquanto, o lado menor permite que a laje seja executada na dimensão desejada.

Os blocos canaleta e compensador têm a mesma função dos blocos jota, porém são assentados sob as lajes em paredes estruturais internas.

Estes blocos permitem que sejam executadas tanto lajes maciças como lajes pré-moldadas.

No entanto, nem todos os fabricantes de blocos fornecem o bloco jota com as dimensões segundo as necessidades dos construtores, principalmente quando a altura da laje ultrapassa $8 \mathrm{~cm}$. Neste caso, pode-se fazer adaptações do bloco jota, colocando-se formas de madeira com altura correspondente à espessura das lajes no perímetro da edificação, ou adotar blocos canaleta também com as formas de madeira dispostas no perímetro da edificação. 
O bloco $\mathrm{J}$ ainda permite que sejam feitos pequenos desníveis de piso ou degraus nas lajes, como mostrado na figura 3.18.

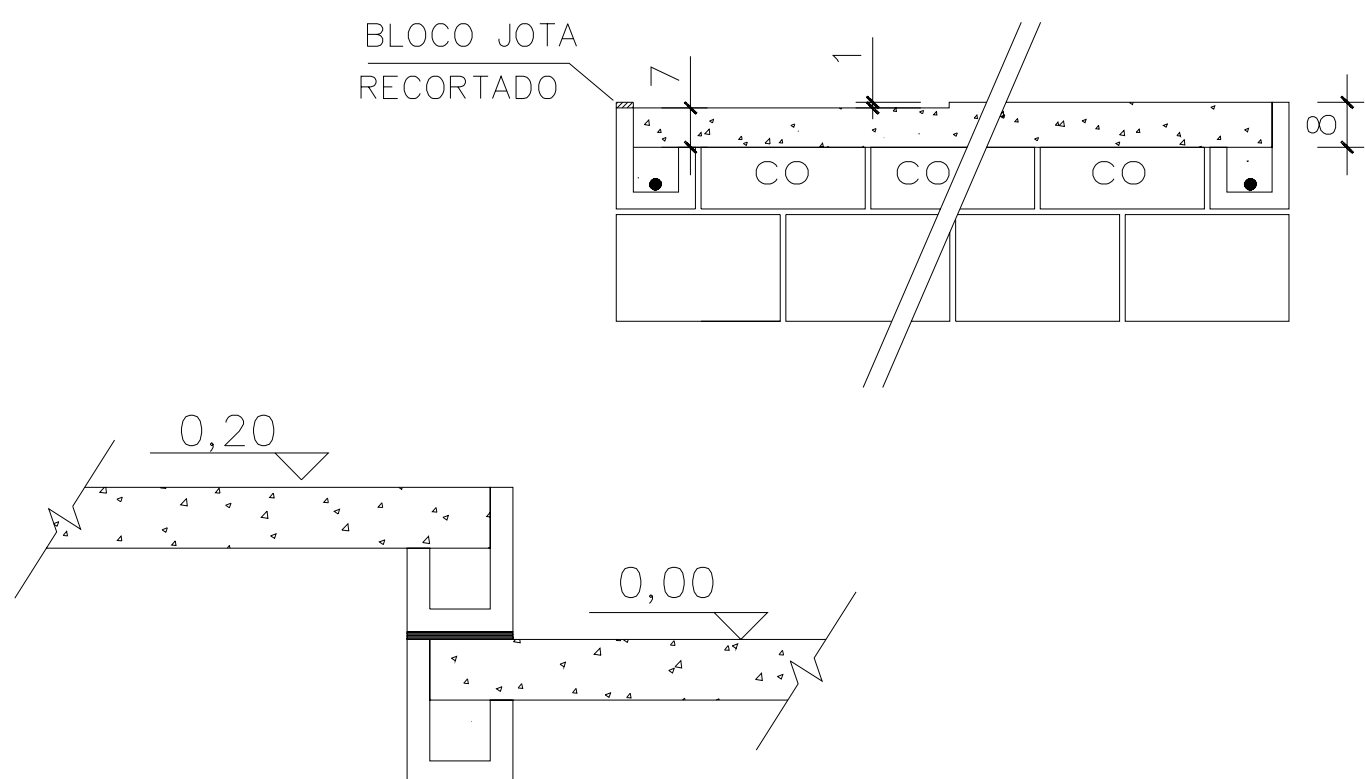

Figura 3.18: Desnível e degrau obtidos com o bloco "jota" (medidas em centímetros e níveis em metros)

É desejável para a racionalização do processo que subsistemas ligados diretamente às paredes estruturais guardem coordenação modular compatíveis com as mesmas. Assim deve ser para lajes, vergas, contravergas e escadas prémoldadas.

Ao adotar este procedimento, evita-se o corte dos componentes e os enchimentos dos ajustes, que são causadores de perdas de materiais, diminuição da produtividade e, conseqüentemente, aumento de custos.

Alguns subsistemas citados neste item serão analisados em capítulos posteriores, onde serão enfocados aspectos específicos ligados à coordenação dimensional. 


\subsection{Considerações Finais}

É imprescindível haver coordenação modular para se obter a racionalização da construção em edificações de alvenaria estrutural.

Os conceitos referentes à coordenação modular são de fácil compreensão e trazem grandes benefícios à construção.

A alvenaria estrutural, por sua vez, apresenta várias especificidades relacionadas à modulação, notadamente quando possui amarradas, as paredes. No entanto procurou-se, neste capítulo, analisar várias alternativas de modulações com indicações de vantagens e desvantagens, para melhores esclarecimentos.

Ressalta-se ainda que a definição adequada do valor do módulo, baseada nas dimensões do bloco, é o primeiro passo para se obter harmonia no sistema como um todo.

Apesar de mais simples, a modulação altimétrica também precisa ser discutida e analisada com os devidos cuidados. E os subsistemas devem guardar compatibilidade dos componentes entre si e entre os componentes de outros subsistemas.

A importância da coordenação dimensional será sentida no decorrer do trabalho, à medida que forem analisados os elementos pré-moldados. Este tema não está definitivamente encerrado, e nem era este o objetivo do trabalho, mas sim trazer informações suficientes para tornar de fácil compreensão posteriores definições dimensionais e executivas pertinentes aos pré-moldados leves. 


\section{ESCADAS PRÉ-MOLDADAS}

Ecadas são elementos da edificação projetados para que o ser
humano, com pequeno dispêndio de energia, consiga ir andando de um nível a outro.

A sua geometria irregular, caracterizada por planos inclinados e dentes, traz transtornos de montagem das formas e da armação e complicações para a concretagem. Por todas as dificuldades que a geometria irregular proporciona, a escada requer um tempo considerável de execução em obra.

Visando minimizar os transtornos provenientes da moldagem das escadas no local, surgem, como alternativa, as escadas pré-moldadas.

O uso de escadas pré-moldadas é muito comum quando a estrutura também é pré-moldada; porém, as vantagens deste componente já se faz sentir em outros sistemas construtivos e, mesmo quando a laje do pavimento for moldada no local, elas não deixam de ser uma solução a se considerar.

Uma das principais vantagens dessas escadas é que, após a sua montagem, os acessos definitivos para o transporte vertical são liberados.

As soluções construtivas ideais para a racionalização do processo são aquelas em que determinados serviços não interferem no andamento dos outros, buscando-se sempre minimizar as operações de grande duração. Baseando-se nesta afirmação, pode-se dizer que a escada pré-moldada ajuda a racionalização do processo. 
As escadas pré-moldadas estão divididas neste trabalho em: escadas compostas por peças de grandes dimensões, e escadas compostas por vários elementos de pequena espessura, passíveis de manuseio sem equipamentos especiais.

Os dois tipos apresentados serão abordados neste trabalho, porém, com o enfoque principal voltado às escadas compostas por elementos leves que melhor se enquadram aos edifícios de alvenaria estrutural e aos objetivos específicos deste trabalho.

\subsection{Escada Pré-moldada Composta por Peças de Grandes Dimensões}

Este tipo de escada pré-moldada é composto por elemento único de grandes dimensões, apoiado diretamente em vigas ou lajes, podendo ter ou não o patamar incorporado, como indicado na figura 4.1.
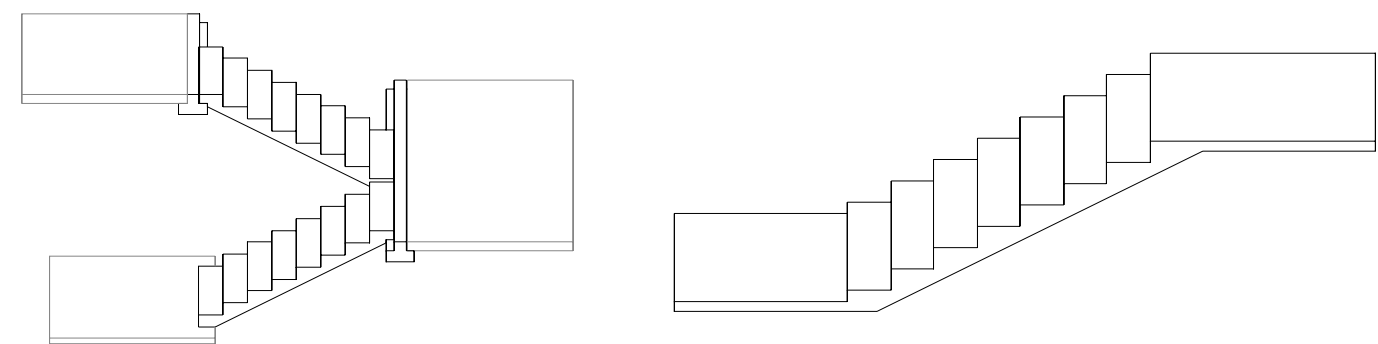

Figura 4.1: Escadas pré-moldadas compostas por peças de grandes dimensões

O peso dos elementos impossibilita-os de serem transportados manualmente, impondo o uso de equipamentos especiais de içamento. Portanto, a adoção deste tipo de escada depende basicamente do equipamento de montagem disponível na obra.

A produção industrial é feita por formas especais metálicas, às quais é permitida alguma liberdade para a regulagem da inclinação, da largura (passo) e da altura (espelho) dos degraus, do comprimento dos patamares e da largura total da escada, possibilitando a uma mesma forma a produção de escadas com várias dimensões, como ilustrado na figura 4.2. 


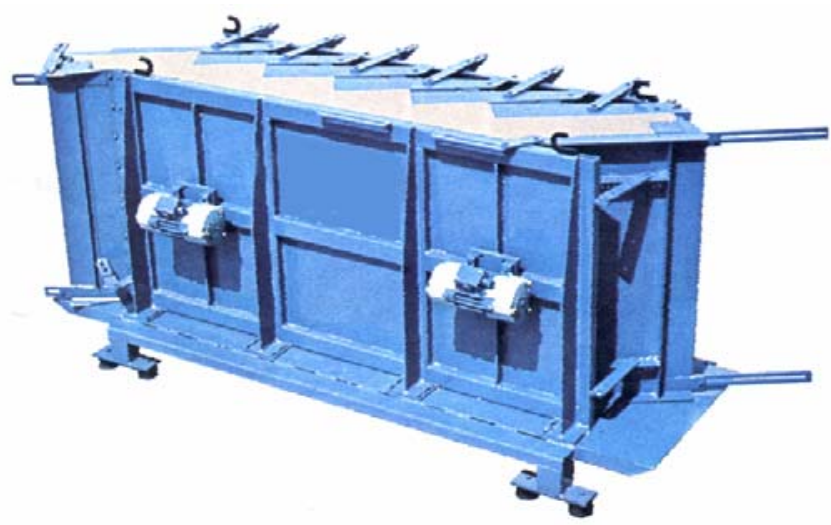

Figura 4.2: Forma metálica de escada composta por peças de grandes dimensões

As formas metálicas permitem alguma flexibilidade de dimensão; porém, apenas de alguns centímetros, significando que, ao se adquirirem escadas pré-moldadas industrializadas, ainda se está sujeito às condições impostas pelos fabricantes quanto às variações dimensionais e sobrecargas máximas.

A norma sobre espaço modular para escadas da ABNT (1982), NBR 5717, prescreve que o passo e o espelho dos degraus devem ser escolhidos de acordo com as exigências do projeto e não são, necessariamente, modulares. No entanto, recomenda que os comprimentos dos degraus sejam.

Atualmente, não há conhecimento de indústrias brasileiras de pré-moldados que atuem no mercado fornecendo escadas compostas por grandes dimensões pelo sistema de industrialização de ciclo aberto; portanto, este tipo de escada fica restrito à industrialização de ciclo fechado, onde não há intercambialidade dos elementos, ou à produção no próprio canteiro de obra, como ilustrado na figura 4.3 .

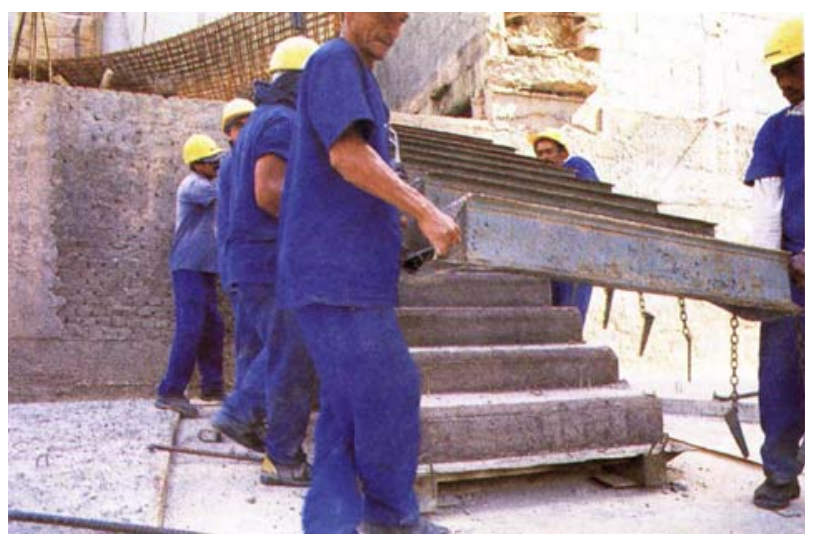

Figura 4.3: Escada pré-moldada produzida no canteiro de obra (KISS, 1998) 
O dimensionamento destes elementos segue o mesmo procedimento usado para as escadas de concreto armado moldadas no local, com o acréscimo das considerações referentes às situações transitórias, em que são freqüentes ocorrerem solicitações diferentes das que ocorrem na situação final.

O transporte por içamento das escadas compostas por elementos de grandes dimensões é um exemplo de situação transitória com solicitações diferentes das que ocorrem na situação final e que devem ser previstas em projeto.

\subsection{Escada Pré-moldada Composta por Vários Elementos}

Este tipo de escada é constituído por vários elementos pré-moldados de concreto armado, de tal forma que cada elemento possa ser manuseado sem o auxílio de equipamentos especiais de içamento.

Usualmente, emprega-se a escada jacaré ou a nervurada, mas há o conhecimento de escadas pré-moldadas espirais.

Nas escadas espirais, os degraus em balanço são ancorados em uma coluna, por uma de suas extremidades, como apresentado na figura 4.4. O próprio degrau, contendo um elemento vazado em sua extremidade, fará o papel de forma para a conformação da coluna. Este tipo de escada, no entanto, apenas será citado neste trabalho, pois não é normalmente usada em edifícios residenciais.
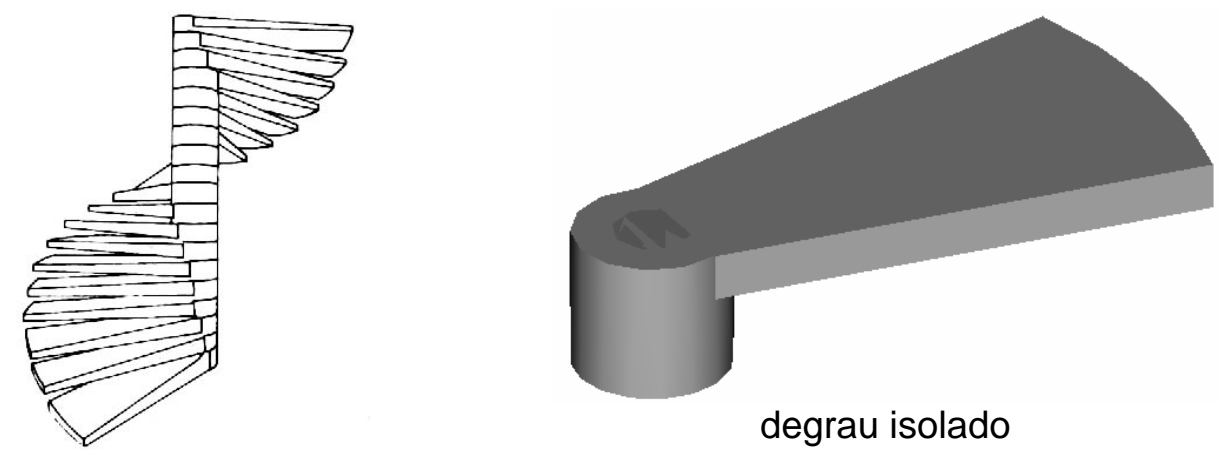

Figura 4.4: Escada pré-moldada espiral (FIP, 1994) 
As vantagens quanto ao manuseio, rapidez de execução, simplificação e a economia são particulares às escadas pré-moldadas compostas por vários elementos:

- $\quad$ o transporte, como anteriormente apresentado, pode ser manual, pois o peso dos componentes o permite, eliminando gastos com equipamentos especiais de içamento;

- a execução em obra resume-se em fixar os componentes no local previsto, favorecendo a rapidez e a simplificação, sendo estas duas características compatíveis com edifícios em alvenaria estrutural, e

- a redução do peso proporcionada pela espessura reduzida traz economia da armadura.

\subsubsection{Escada Nervurada}

As escadas nervuradas assemelham-se às lajes pré-fabricadas nervuradas compostas por: vigotas pré-moldadas (geralmente treliçadas), elemento de enchimento como blocos vazados ou de poliestireno expandido, capeamento de concreto moldado no local e, eventualmente, armadura na capa de concreto, como ilustrado na figura 4.5 .
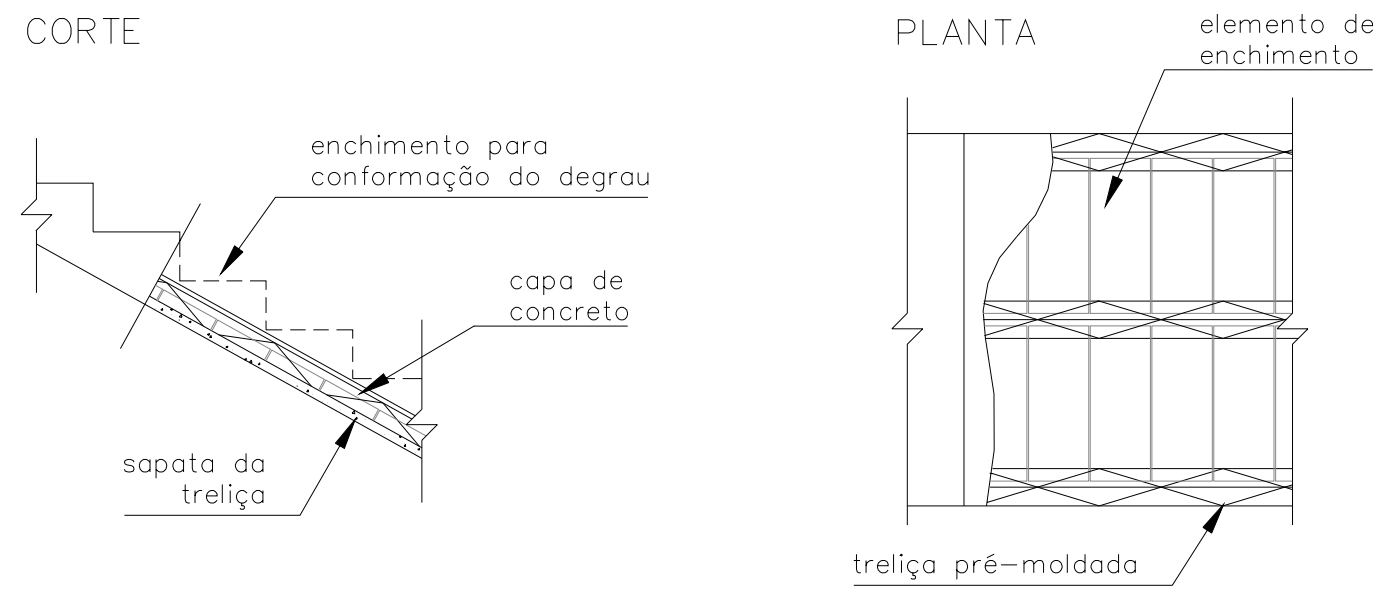

Figura 4.5: Escada nervurada

A execução das escadas inicia-se com a disposição inclinada das nervuras e com o enchimento sobre o vão; segue, quando necessário, com a 
disposição da armadura, com o capeamento de concreto e finaliza com a conformação dos degraus.

Os elementos pré-moldados utilizados para a execução deste tipo de escada são apropriados ao manuseio do operário, eliminando a necessidade do uso de equipamentos especiais de içamento.

Apesar da aparente simplicidade do sistema, a etapa de conformação dos degraus exige que formas sejam executadas nas dimensões exatas e cuidados com a cura do concreto devem ser tomados. Portanto, a vantagem adquirida com a rapidez da adoção de nervuras pré-moldadas pode ser perdida na fase de conformação dos degraus moldados no local.

\subsubsection{Escada Jacaré}

A escada jacaré é um expressivo exemplo do uso de elementos pré-moldados de pequena espessura compatíveis com o manuseio do operário da construção e plenamente aplicáveis em edifícios de alvenaria estrutural.

A afinidade entre o processo construtivo em alvenaria estrutural e as escadas jacaré está na presença de paredes portantes capazes de suportarem as cargas provenientes do chumbamento de peças pré-moldadas e pelo fato de os elementos pré-moldados da escada chegarem ao local de execução já prontos, restando apenas a montagem no devido local.

Em geral, a escada jacaré é composta por:

- $\quad$ duas vigas denteadas ou vigas jacaré;

- $\quad$ degraus em "L";

- $\quad$ patamares pré-moldados;

- peças de apoio do patamar, e

- peças complementares de ajuste.

Os elementos principais que compõem a escada estão ilustrados na figura 4.6. 
A escada jacaré é assim denominada pois os dentes da viga de sustentação assemelham-se à cauda de um jacaré.

O peso máximo dos elementos pré-moldados é de $50 \mathrm{~kg}$ por operário (GRANDJEAN, 1991), o que leva o projetista à redução das dimensões das peças. Há a possibilidade das peças serem manuseadas por dois operários, elevando-se o limite de peso para $100 \mathrm{~kg}$.
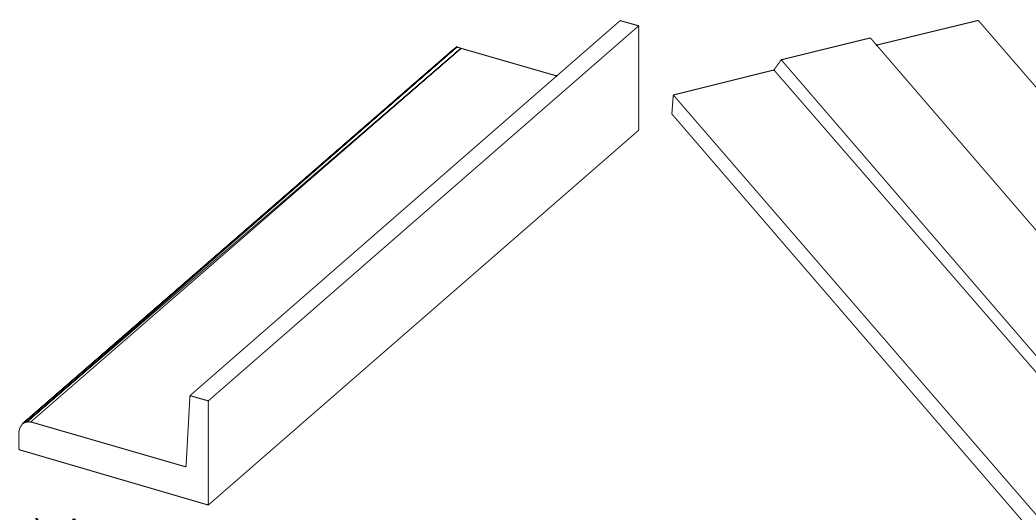

a) degrau

b) patamar

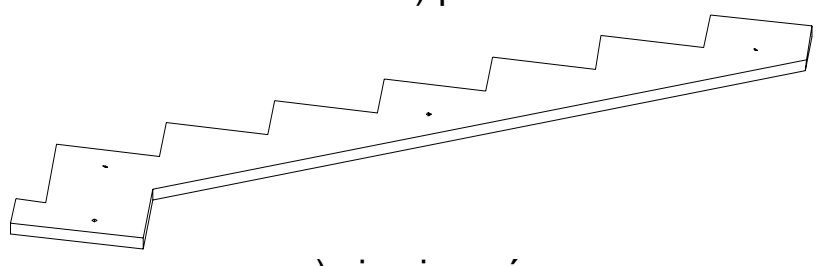

c) viga jacaré

Figura 4.6: Elementos constituintes da escada jacaré: degrau [a]; patamar [b] e viga denteada ou viga jacaré [c]

Uma opção para trabalhar-se com pequenas espessuras é o uso de concretos de granulometria fina, cobrimento da armadura de $1 \mathrm{~cm}$ e diâmetro das barras de aço de, no máximo, $6,3 \mathrm{~mm}$.

Neste tipo de escada, os ajustes referentes aos elementos pré-moldados devem ser considerados na fase de projeto.

Ajuste é a diferença entre a medida nominal de dimensão de projeto reservada para a colocação de um elemento e a medida nominal da dimensão correspondente do elemento (ABNT, 1985 - NBR 9062). A partir do valor do ajuste, são determinadas as dimensões nominais de fabricação. O valor do ajuste engloba: 
folga, tolerância e variação do comprimento (alongamentos ou encurtamentos), causados pela retração, fluência ou variação da temperatura. É usual adotar ajustes de $5 \mathrm{~mm}$ para elementos pré-fabricados de pequena espessura.

A tolerância é o valor máximo aceito para a diferença entre a dimensão estabelecida no projeto do elemento e a correspondente executada, e é constituída por parcelas de execução, montagem e locação das peças. Os valores a se considerarem para cada parcela encontram-se tabelados pela ABNT (1985), NBR 9062.

Folga para ajuste positivo é a diferença entre a medida mínima de dimensão de projeto reservada para a colocação de um elemento e a medida máxima da dimensão correspondente do elemento.

A terminologia "folga", comumente, é aplicada pelo meio técnico para designar ajustes; porém, a NBR 9062 especifica claramente a função de cada terminologia.

Para garantir o comportamento eficaz dos elementos, cuidados devem ser tomados na fase de execução, principalmente com relação às dimensões, ao cobrimento da armadura e ao acabamento final. As pequenas espessuras e o cobrimento mínimo exigem técnicas apuradas de execução. São bem aceitas as técnicas aplicadas à argamassa armada, juntamente com um controle de execução. Os ajustes dimensionais precisam ser rigorosamente respeitados e o acabamento final da superfície das peças deve apresentar boa aparência, pois, muitas vezes, não se fará uso de revestimentos.

Sugere-se o uso de formas metálicas para atender aos cuidados propostos, porém, esta é uma decisão a ser tomada pelo construtor, que analisará a relação custo/benefício que o investimento trará para seu empreendimento.

A conformação da escada começa pelo chumbamento das vigas denteadas na alvenaria. O chumbamento é feito com buchas e parafusos ou com chumbadores; para tanto, é recomendável preestabelecer os furos nas vigas e preferencialmente, preencher os blocos que receberão os parafusos com graute. 
Imediatamente após a fixação dos elementos, a escada é liberada para o uso, servindo, desse modo, como meio para o transporte vertical de pessoas e materiais durante a etapa de construção.

O dimensionamento da viga jacaré é simples, pois considera-se a viga apoiada nos locais correspondentes à fixação do parafuso. O carregamento a que deve estar submetida corresponde ao peso próprio, à contribuição do peso do degrau e ao carregamento de utilização. Os degraus são biapoiados nas vigas pelas suas extremidades.

O projeto das escadas pré-moldadas deve ser executado com rigores de detalhes, com todos os elementos desenhados separadamente e com escalas ampliadas. Compatibilizar o processo como um todo, e não apenas o subsistema de escadas, é fundamental, durante a etapa do projeto.

Para o completo entendimento da escada jacaré, dos seus componentes pré-moldados e das interferências entre eles, será apresentado um roteiro de projeto e a seguir, um exemplo de dimensionamento dos elementos da escada pré-moldada para um edifício em alvenaria estrutural. O exemplo é um estudo de caso baseado no projeto gentilmente cedido pela TecSof Engenharia de Estruturas S/C Ltda.

\subsubsection{Roteiro de Projeto}

O roteiro apresentado para elaboração do projeto de uma escada pré-moldada jacaré engloba diretrizes para as definições preliminares, para a concepção e o dimensionamento dos elementos, para o detalhamento das armaduras e para a apresentação final do projeto.

É importante haver compatibilidade entre a escada e outros subsistemas, como por exemplo, prever as paredes de apoio com larguras suficientes para a fixação das vigas jacaré; observar a possível interferência de janelas comumente encontradas na caixa de escada; analisar eventuais aberturas nos patamares das escadas destinadas à localização de shafts para a passagem das tubulações. 


\section{A. Definições preliminares}

A partir do projeto arquitetônico modulado extrair-se-ão: os valores da altura de piso a piso, da largura do vão total da escada e a forma geométrica (escadas em L, em $\mathrm{U}$, patamares adjacentes etc); com os quais será possível definir as dimensões e a geometria dos elementos pré-moldados da escada.

O vão vertical a ser vencido, que depende do pé direito da edificação, é um parâmetro para determinar o valor da altura do degrau (espelho). A espessura de regularização da laje e os revestimentos devem ser considerados.

Outro parâmetro para definição das dimensões dos degraus é a indicação da bibliografia, de valores limites para o passo (s) e para o espelho (e).

$$
\begin{aligned}
& \mathrm{s} \geq 25 \mathrm{~cm} \\
& \mathrm{e} \leq 19 \mathrm{~cm}
\end{aligned} \quad \mathrm{~s}+2 \times \mathrm{e}=60 \mathrm{a} 64 \mathrm{~cm}
$$

É interessante incluir nas definições preliminares a tecnologia adotada pela empresa para a produção dos elementos pré-moldados, pois, como o peso máximo dos elementos é limitado em $50 \mathrm{~kg}$ por operário, o projetista trabalha com dimensões reduzidas das peças e sendo assim, obter dados como a massa específica do concreto, a resistência à compressão $\left(f_{c k}\right)$ e os cobrimentos da armadura, facilitará a tomada de decisões.

A definição da maneira de produção dos elementos pré-moldados também pode alterar as considerações tomadas durante o projeto dos elementos. Por exemplo, elementos executados em formas metálicas apresentam dimensões precisas e boa aparência; portanto, são capazes de serem usados sem revestimento. Já os elementos produzidos em formas de madeira podem necessitar de maiores ajustes para montagem no local, além de precisarem de uma camada de revestimento, o que aumentaria o carregamento.

Nesta fase, é importante explorar, ao máximo, os recursos já existentes da empresa e atentar para o nível de profissionalização dos operários e para o nível tecnológico da obra. 


\section{Resumo - A definir na etapa de "Definições Preliminares"}

Obter as dimensões moduladas dos vãos da escada

Determinar os valores do passo e do espelho dos degraus

Definir a tecnologia adotada para a produção das peças pré-moldadas: massa específica, fck, cobrimento da armadura.

Definir o modo de produção (definição do material das formas)

\section{B. Concepção dos elementos pré-moldados}

Todos os elementos que constituirão a escada jacaré devem ser estudados e projetados sob os aspectos dimensionais, executivos e estruturais.

Não deve haver tomada de decisões no local de montagem da escada; para tanto, a etapa de concepção do projeto assume papel fundamental no processo, buscando-se soluções simples e facilmente compreensíveis por quem as executa.

Os vãos da escada já foram previamente determinados na etapa de definições preliminares. A partir destes dados, as peças serão desenhadas; ainda assim, a consulta à planta da arquitetura é um auxílio de grande valia que evitará possíveis interferências com outros subsistemas, como as diferenças de níveis ou a localização das janelas.

A interface escada-laje é região com problemas de ajustes dimensionais que podem ser resolvidos com peças pré-moldadas complementares, com a previsão de rebaixos na borda livre das lajes ou avanço da laje no vão da escada.

Recomenda-se adicionar ao projeto de elevação da alvenaria, a locação dos elementos constituintes da escada jacaré. Esta prática facilita o projetista visualizar alterações nas paredes estruturais, como por exemplo, quais blocos serão grauteados para a fixação da viga jacaré na parede e facilita também ao construtor, identificar, com facilidade, a região onde estarão localizadas as peças pré-moldadas.

A padronização dos elementos resulta no aprimoramento da fabricação e na melhoria dos procedimentos de instalação dos elementos, aumentando-se a produtividade. 
Eventualmente, certas especificidades de projeto obrigam a fuga do padrão da concepção dos elementos. Nestes casos, analisa-se a possibilidade de aproveitamento das formas já existentes, fazendo-se adaptações. Por exemplo, quando há diferenças nas alturas de pé direito dos pavimentos térreo e tipo, em vez de conceber uma nova viga jacaré de comprimento maior para o vão de maior altura, tenta-se fazer uso de duas vigas projetadas para o pavimento tipo, fazendo-se pequenas adaptações.

Durante a definição das dimensões das peças, não se esquecer de considerar o ajuste dimensional, referente aos pré-moldados de pequena espessura, que dependerá, dentre outros fatores, do material adotado para a forma.

\section{Resumo - A definir na etapa de "Concepção"}

\begin{tabular}{|c|c|}
\hline \multicolumn{2}{|c|}{$\begin{array}{l}\text { Geometria e dimensões de todos os elem } \\
\text { escada } \\
\text { Eventuais interferências com a arquitetura }\end{array}$} \\
\hline Peças & A definir: \\
\hline egrau & forma, comprimento, passo, espelho e espessura. \\
\hline $\begin{array}{l}\text { 'iga } \\
\text { enteada }\end{array}$ & $\begin{array}{l}\text { espessura, altura e comprimento do dente e da viga, inclinação, furos } \\
\text { para passagem do chumbador, dentes de apoio (para peças de } \\
\text { ajuste). }\end{array}$ \\
\hline atamar & $\begin{array}{l}\text { forma, comprimento, largura e espessura, tipo de solidarização entre } \\
\text { as peças do patamar, caso haja mais de uma. }\end{array}$ \\
\hline $\begin{array}{l}\text { eças de } \\
\text { poio }\end{array}$ & $\begin{array}{l}\text { comprimento, altura, espessura e localizações dos furos para } \\
\text { passagem dos chumbadores. Deve-se respeitar a distância mínima } \\
\text { do furo à extremidade da peça, segundo orientação do fabricante de } \\
\text { chumbadores. }\end{array}$ \\
\hline $\begin{array}{l}\text { eças de } \\
\text { uste }\end{array}$ & $\begin{array}{l}\text { comprimento, altura e espessura, prevendo-se reaprc } \\
\text { formas }\end{array}$ \\
\hline
\end{tabular}

\section{Dimensionamento}

Após a aprovação das peças pré-moldadas pelo construtor, à vista da viabilidade de produção no canteiro de obra e execução da escada pela empresa, o projeto entra na etapa de dimensionamento e detalhamento das armaduras.

Para o dimensionamento, segue-se o convencional para concreto armado: cálculo do carregamento, definição do esquema estático, cálculo das armaduras longitudinais e transversais e verificações do estado limite de utilização. 
Como as peças têm pequenas espessuras, as verificações do cisalhamento, fissuração e deformação têm grande importância; no entanto, como a solicitação é pequena, dificilmente ocorrerão problemas.

Os métodos de cálculo para as verificações, desde que a peça não seja armada com telas soldadas, podem ser os mesmos utilizados para peças em concreto armado, segundo prescrições da ABNT (1978), NBR 6118.

Conforme a ABNT (1980), NBR 6120, uma escada constituída de degraus isolados deve ser dimensionada para um acréscimo de força concentrada de 2,5 kN, aplicada na posição mais desfavorável.

Acha-se conveniente considerar o limite para abertura de fissuras de $0,15 \mathrm{~mm}$, referente a peças de argamassa armada (HANAl, 1992), pois os elementos pré-moldados têm cobrimento de pequena espessura.

Para o valor do módulo de deformação longitudinal de um concreto de granulometria fina, indica-se a especificação da norma soviética de argamassa armada (HANAI, 1992) de 0,80 do módulo determinado para o concreto usual de mesma resistência.

As ligações da viga jacaré e das peças de apoio nas paredes estruturais devem ser dimensionadas coerentemente com o tipo de conector de ligação adotado: parafuso ou chumbador. Os parafusos são dimensionados conforme especificações da ABNT (1986), NBR 8800; os chumbadores, sob consulta a manuais de fabricantes. A capacidade resistente da parede é verificada por adaptações à teoria de introdução de esforços, por meio de pinos em peças de concreto, descritas por LEONHARDT \& MÖNNING (1978), com as devidas adaptações para as condições normativas brasileiras. Há indicação para minorar a força última resistente da parede por um coeficiente de segurança equivalente a 5.

Para a verificação da capacidade resistente da parede, recomenda-se utilizar $\mathrm{f}_{\mathrm{gk}}$ de $9 \mathrm{MPa}$, que é a resistência de um prisma cheio, composto de blocos de 4,5 MPa, resistência mínima permitida para blocos estruturais de concreto segundo a ABNT (1994), NBR 6136. Salienta-se que para os blocos estruturais cerâmicos, a resistência mínima permitida é $6 \mathrm{MPa}$, o que resulta em um $\mathrm{f}_{\mathrm{gk}}$ de $12 \mathrm{MPa}$. 
Inicialmente, é proposto o diâmetro do chumbador de $12,5 \mathrm{~mm}$, porém este valor pode ser alterado dependendo do caso.

\section{Resumo - Atividades a se cumprirem na etapa de "Dimensionamento"}

Calcular: carregamento, esforços, armaduras longitudinais e transversais (estribos)

Verificar: cisalhamento, fissuração, deformação excessiva e capacidade resistente da parede.

Dimensionar a ligação por chumbador ou parafuso

\section{Desenho final - Detalhamento}

A apresentação final do projeto das escadas jacaré pré-moldadas será satisfatória se contiver todas as soluções adotadas com fácil visualização e entendimento.

Recomenda-se apresentar os seguintes itens:

- $\quad$ especificações com clareza;

- desenho de todas as peças em planta, em perfil e com cortes apropriados;

- locação das peças na planta de arquitetura, contendo previsão dos ajustes na interface das peças;

- $\quad$ listagem com quantidades de: peças, armaduras e volume de concreto;

- $\quad$ especificação das paredes e dos blocos grauteados para a fixação dos chumbadores;

- detalhamento de todos os elementos, em escala adequada (recomenda-se 1:20) e,

- $\quad$ projeto para a produção.

O projeto para produção é, resumidamente, definido, baseado em BARROS (apud VILATÓ, 1998), como um conjunto de elementos de projeto elaborado segundo características e recursos da empresa construtora, contendo as definições dos itens essenciais à realização de uma atividade ou serviço para as atividades de produção em obra. 


\subsubsection{Exemplo de projeto}

O exemplo de projeto da escada jacaré, apresentado neste item, é um estudo de caso baseado no projeto cedido pela TecSof Engenharia de Estruturas S/C Ltda, em que será aplicado o roteiro previamente discutido, comentando-se as considerações adotadas.

\section{A. Definições Preliminares}

As peças pré-moldadas da escada serão executadas no próprio canteiro da obra e far-se-á uso de formas metálicas que proporcionam bom acabamento superficial, fazendo com que seja dispensado o revestimento sobre as peças.

Com o uso das formas metálicas, também será possível estimar ajuste de valor equivalente a $0,5 \mathrm{~cm}$ nas dimensões das peças.

Adotou-se um concreto de granulometria fina de resistência característica à compressão $\left(f_{c k}\right)$ aos 28 dias, equivalente a $25 \mathrm{MPa}$. A massa específica adotada é de $2400 \mathrm{Kg} / \mathrm{cm}^{3}$ e o cobrimento da armadura, de $1 \mathrm{~cm}$.

O transporte dos elementos pré-moldados e a montagem no local previsto para a utilização não contarão com equipamentos de içamento; portanto, o peso máximo das peças precisa ser compatível com a capacidade portante dos operários que irão manuseá-las, ou seja, 50 kg por trabalhador.

A figura 4.7 apresenta a planta arquitetônica da região da escada do projeto a ser exemplificado. 


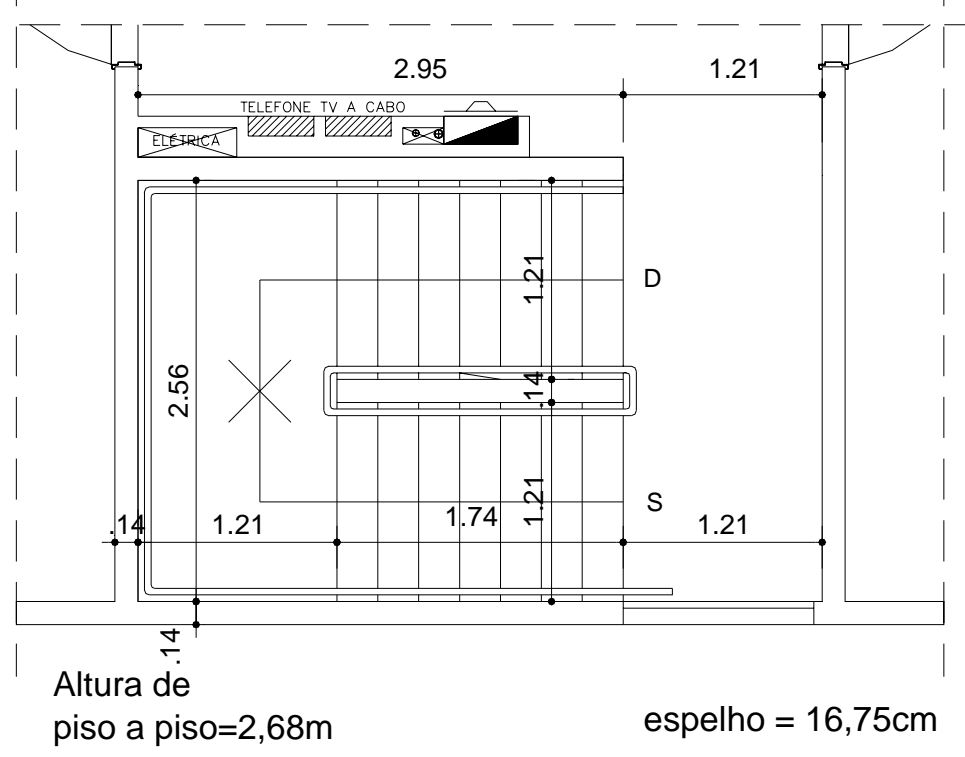

Figura 4.7: Planta da arquitetura da região da escada

\section{B. Concepção dos elementos}

Durante a concepção dos elementos pré-moldados, atentar para todas as interferências possíveis dos elementos entre si e com a estrutura.

Algumas peças para o assentamento adequado contam com alguns recortes, como acontece com módulos do patamar, esquematizado na peça 3 da figura 4.10 .

Para o primeiro espelho (peça 2A) e o último passo (peça 2B), são necessárias peças de ajuste, as quais devem ser previstas e detalhadas em projeto, como pode ser visualizado nos cortes da figura 4.9. Procurou-se racionalizar o sistema, com o reaproveitamento das formas do degrau para a confecção dessas peças.

A laje do pavimento deve ter um avanço de $7,5 \mathrm{~cm}$ no vão da escada, para que haja compatibilidade entre o primeiro lance da escada (peça 1A) e o pavimento tipo, como se observa nos cortes apresentados na figura 4.9. Já na laje do pavimento superior, deve haver um rebaixo de $6,5 \mathrm{~cm}$ para compatibilizar com a chegada do segundo lance da escada. 
A altura da peça 5 (apoio do patamar) foi determinada em função da distância mínima permitida entre o furo, para passagem do chumbador, e a borda externa da peça.

Priorizou-se a geometria reta, durante a concepção dos pré-moldados, o que garantirá facilidade na fabricação e montagem das formas. Não se recomendam cantos com ângulos menores que $90^{\circ}$, pois pode danificar a peça na etapa de desforma.

Previram-se rebaixos nas interfaces entre as peças, onde ocorrerá a solidarização dos patamares com a aplicação do concreto moldado no local (peça 3).

A localização dos furos nas peças pré-moldadas para a fixação de parafusos ou chumbadores é apresentada claramente, contendo as dimensões do furo e a sua localização na peça, como mostrado na figura 4.8.

\section{Detalhe da localizacao da furação}

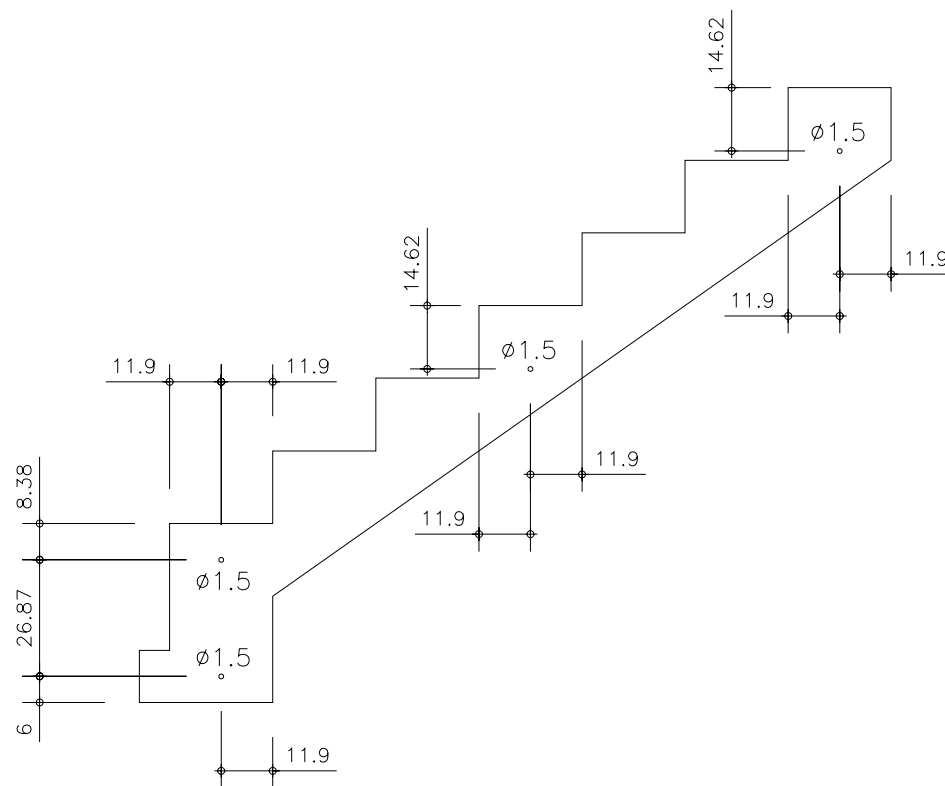

Figura 4.8: Localização e dimensão dos furos na viga jacaré (Dimensões em cm) 


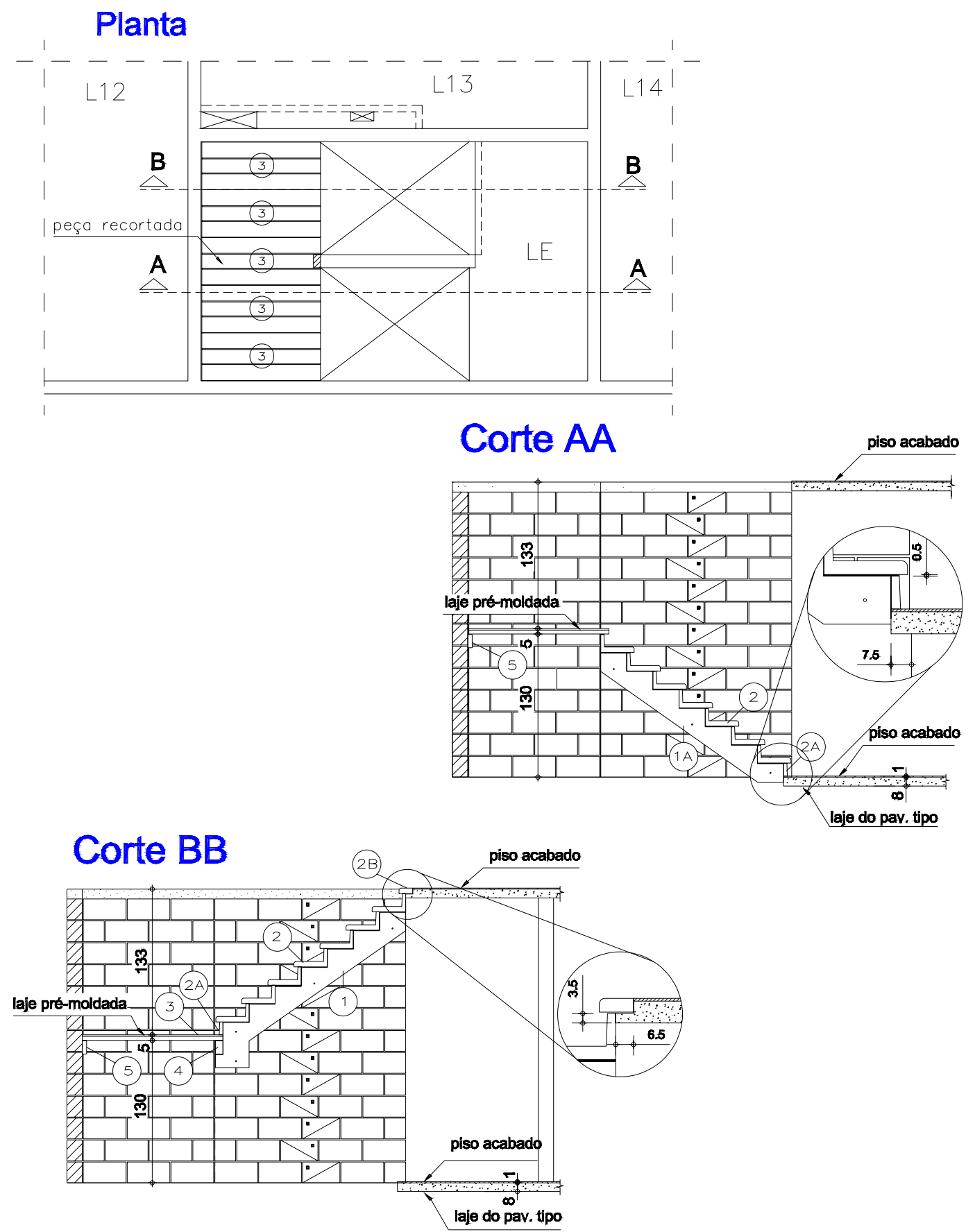

Figura 4.9: Planta e cortes da escada pré-moldada (cortesia da TecSof Engenharia de Estruturas S/C Ltda)

O projeto na íntegra deve conter, em detalhes todos os elementos numerados nos cortes apresentados na figura 4.10. A título de exemplo, são apresentados apenas alguns deles. 


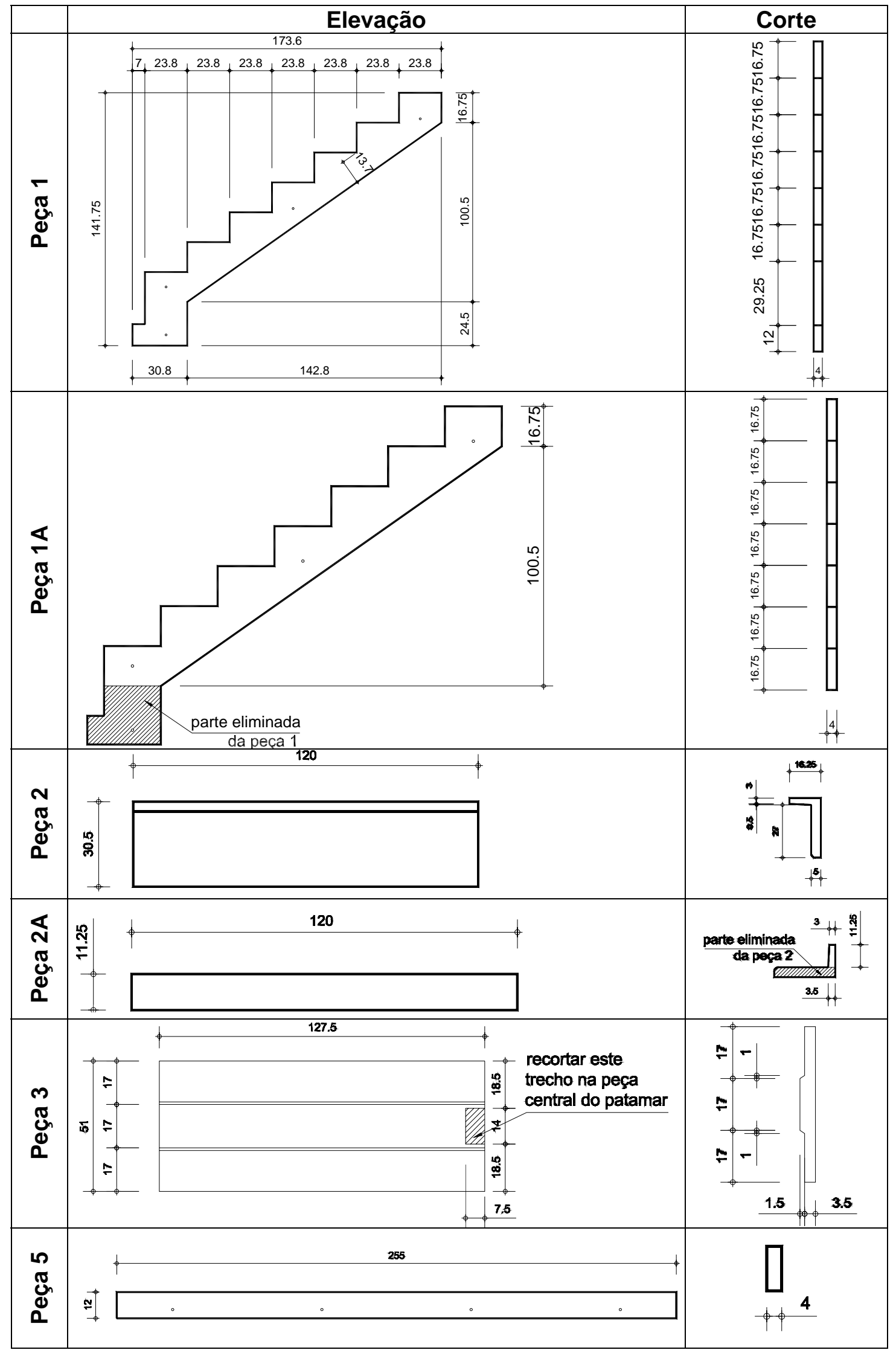

Figura 4.10: Elevação e corte das peças pré-moldadas da escada 


\section{ESCADAS \\ DEPARTAMENTO DE ENGENHARIA DE ESTRUTURA - EESC/USP}

\section{Dimensionamento e detalhamento}

O dimensionamento completo será demonstrado para o degrau, o patamar e a viga denteada; as demais peças serão apresentadas apenas com a armadura detalhada.

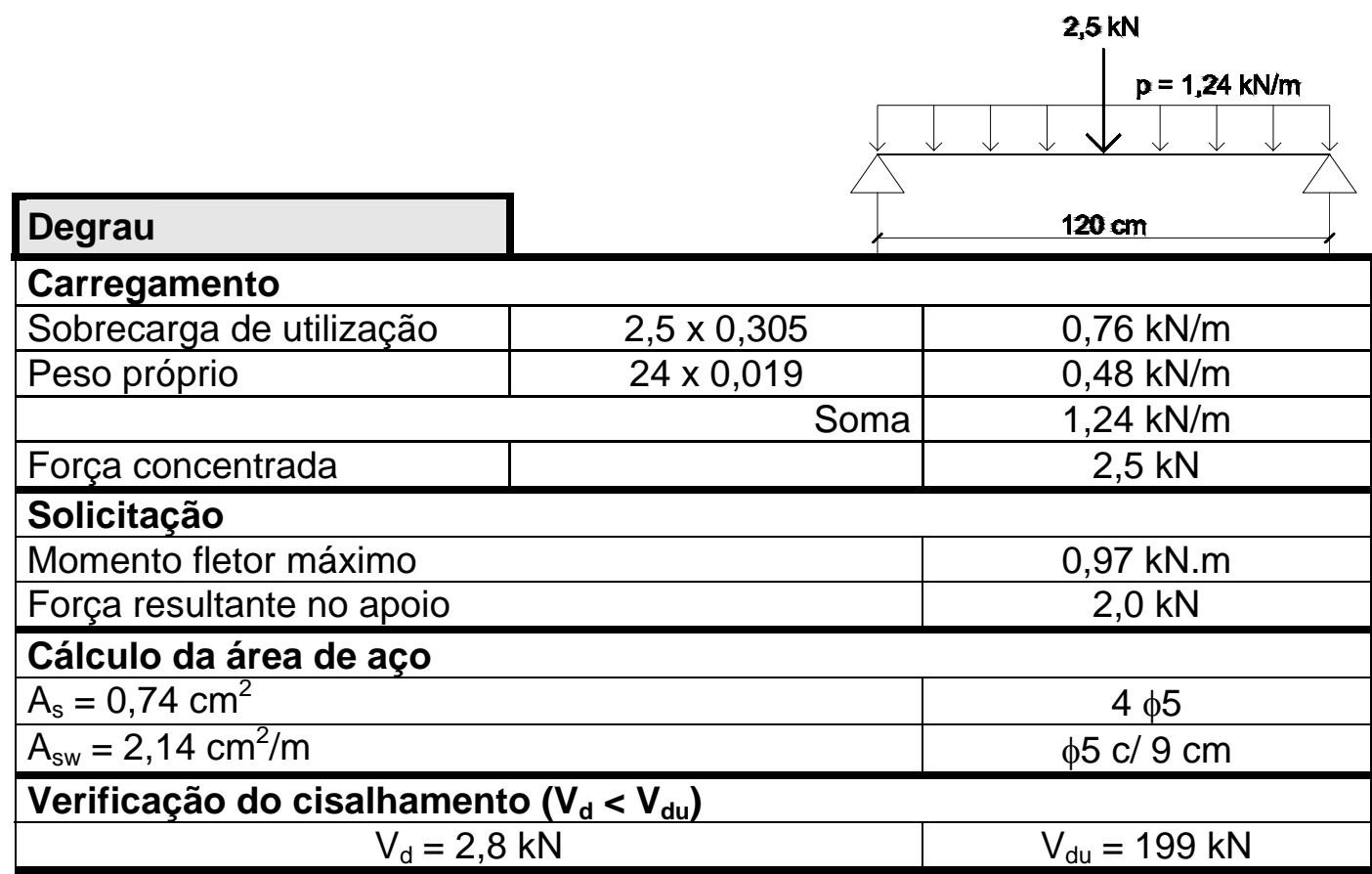

$\mathrm{p}=3,7 \mathrm{kN} / \mathrm{m} 2$

\begin{tabular}{|c|c|c|}
\hline Patamar & \multicolumn{2}{|c|}{$127,5 \mathrm{~cm}$} \\
\hline \multicolumn{3}{|l|}{ Carregamento } \\
\hline Sobrecarga de utilização & 2,5 & $2,5 \mathrm{kN} / \mathrm{m}^{2}$ \\
\hline Peso próprio & $24 \times 0,05$ & $1,2 \mathrm{kN} / \mathrm{m}^{2}$ \\
\hline & Soma & $3,7 \mathrm{kN} / \mathrm{m}^{2}$ \\
\hline \multicolumn{3}{|l|}{ Solicitação } \\
\hline Momento fletor máximo & & $0,75 \mathrm{kNm} / \mathrm{m}$ \\
\hline \multicolumn{3}{|l|}{ Cálculo da armadura } \\
\hline$A_{s}=A_{s, \min }=0,75 \mathrm{~cm}^{2} / \mathrm{m}$ & & $\phi 5 c / 10$ \\
\hline \multicolumn{3}{|c|}{ Verificação da Força Cortante $\left(\tau_{w d}<\tau_{w u}\right)$} \\
\hline$\tau_{\mathrm{wd}}=0,48 \mathrm{MPa}$ & & $\begin{array}{c}\tau_{\mathrm{wu}}=2,7 \mathrm{MPa} \\
\tau_{\mathrm{wu} 1}=1,0 \mathrm{MPa}\end{array}$ \\
\hline
\end{tabular}

Conforme verificações feitas, segundo a ABNT (1978), NBR 6118, para força cortante em lajes, não é necessária a armadura transversal; no entanto, aconselha-se colocá-la por questões construtivas; além de contribuir para absorver os esforços provenientes de situações transitórias (transporte, armazenamento). 


\section{Viga denteada}

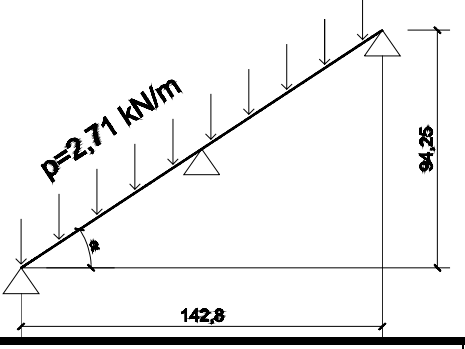

\section{Carregamento}

Peso próprio

Contribuição do degrau

Sobrecarga de utilização

$0,25125 \times 0,04 \times 24$
$55 / 100 \times 2 \times 0,283$

$2,5 \times 1,2 / 2$

Decomposição da força perpendicular ao plano da

escada $-P / \cos \alpha$

\section{Solicitação}

Momento fletor positivo

Momento fletor negativo

Força resultante máxima no apoio

$0,24 \mathrm{kN} / \mathrm{m}$

$0,97 \mathrm{kN} / \mathrm{m}$

$1,5 \mathrm{kN} / \mathrm{m}$

$2,71 \mathrm{kN} / \mathrm{m}$

Cálculo da área de aço

$A_{s}=A_{s, \min }=0,08 \mathrm{~cm}^{2}$
$A_{s w}=0,56 \mathrm{~cm}^{2} / \mathrm{m}$

$3,24 \mathrm{kN} / \mathrm{m}$

Verificação do cisalhamento $\left(\mathrm{V}_{\mathrm{d}}<\mathrm{V}_{\mathrm{du}}\right)$

$$
\mathrm{V}_{\mathrm{d}}=4,8 \mathrm{kN}
$$

$0,164 \mathrm{kN} \cdot \mathrm{m}$

$0,293 \mathrm{kN} . \mathrm{m}$

$3,45 \mathrm{kN}$

Verificação da Situação Provisória: transporte de vigas pré-moldadas

A viga denteada pré-moldada pode ser transportada deitada por dois operários, segurando em suas extremidades. Durante o transporte, portanto, surgem solicitações diferentes daquelas previstas no cálculo da estrutura, podendo resultar em fissuras na peça.

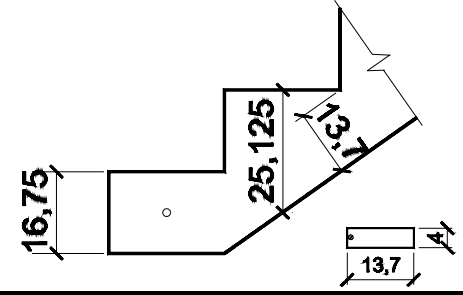

\section{No caso previsto para o transporte, a} viga passa a ter:

base $(\mathrm{bw})=13,7 \mathrm{~cm}$ altura $=4 \mathrm{~cm}$

\begin{tabular}{|l|l|}
\hline \multicolumn{2}{|l|}{ Verificação da Fissuração } \\
\hline Carregamento \\
\hline Peso próprio & $24 \times 0,04 \times 0,26$ \\
\hline Momentos & $0,25 \mathrm{kN} / \mathrm{m}$ \\
\hline Momento atuante $\left(\mathrm{M}_{\mathrm{at}}\right)$ & $9,0 \mathrm{kN} . \mathrm{cm}$ \\
\hline Momento de fissuração $\left(\mathrm{M}_{\mathrm{cr}}\right)$ & $8,4 \mathrm{kN} . \mathrm{cm}$ \\
\hline
\end{tabular}

Como $\mathrm{Mcr}$ < Mat a peça irá fissurar se não tiver armadura para combater o momento atuante. Portanto, devem-se colocar $2 \phi 5 \mathrm{~mm}$, como esquematizado na figura 4.11. 


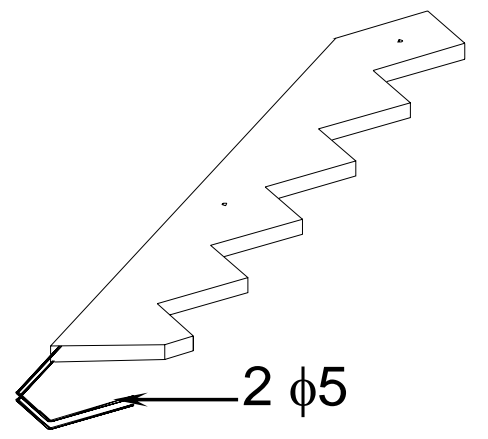

Figura 4.11: Detalhe da armadura longitudinal da viga denteada

$\mathrm{Na}$ figura 4.11, se encontra detalhada apenas a armadura longitudinal, para facilitar a compreensão do desenho; porém, a armadura transversal também é necessária, como pode ser observado na figura 4.12 .

\section{Verificação do dente de apoio da viga jacaré (peça $\left.n^{\circ} 1\right)$}

O comportamento dos dentes pode ser considerado como o dos consolos e as hipóteses de cálculo indicadas pela ABNT (1985), NBR 9062, para consolos, com relação dimensional de $a / d \leq 0,5$ (consolo muito curto), são as do atrito-cisalhamento.

Segundo EL DEBS (2000), o modelo do atrito-cisalhamento assume que "o concreto submetido a tensões de cisalhamento desenvolve uma fissura no plano destas tensões. A integridade das partes separadas por esta fissura potencial é garantida pela colocação de uma armadura cruzando a superfície definida pela fissura, que na tendência de separação das partes, produz força normal a ela. Esta força normal mobiliza força de atrito, de forma a equilibrar o cisalhamento atuante".

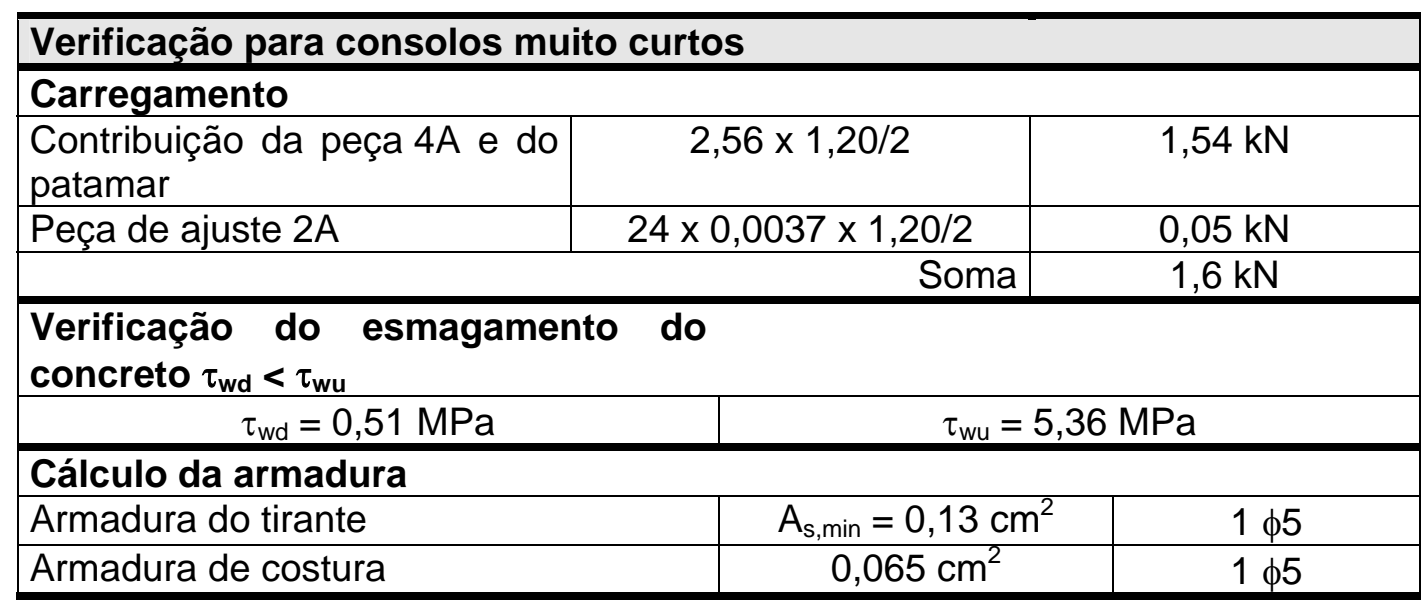




\section{Verificações do Estado Limite de Utilização}

\section{Verificação da Fissuração}

Combinação freqüente de utilização: $F_{\mathrm{d}, \text { freq }}=F_{\mathrm{gk}}+0,3^{*} F_{\mathrm{qk}}$

São 2 as verificações a serem feitas:

a) $\frac{1}{10} * \frac{\phi_{l}}{2 \eta_{b}-0,75} * \frac{\sigma_{s}}{E_{s}}\left(\frac{4}{\rho_{r}}+45\right)<0,15 \mathrm{~mm}$

b) $\frac{1}{10} * \frac{\phi}{2 \eta_{b}-0,75} * \frac{\sigma_{s}}{E_{s}} * \frac{3 * \sigma_{s}}{f_{t k}}<0,15 \mathrm{~mm}$

\begin{tabular}{|l|c|c|}
\hline Peça & Momento $\mathbf{M}_{\text {freq }}(\mathbf{k N . c m})$ & Verificações $(\mathbf{m m})$ \\
\hline Degrau & 35,00 & $\begin{array}{l}\text { a) } 0,042 \\
\text { b) } 0,005\end{array}$ \\
\hline Viga jacaré & 18,06 & $\begin{array}{l}\text { a) } 0,019 \\
\text { b) } 0,007\end{array}$ \\
\hline Patamar & 20,12 & $\begin{array}{l}\text { a) } 0,054 \\
\text { b) } 0,012\end{array}$ \\
\hline
\end{tabular}

$\mathrm{O}$ valor da resistência à tração $\left(\mathrm{f}_{\mathrm{ctk}}\right)$ foi reduzido de 0,75 , como simplificação para considerar o efeito de retração (NBR 6118).

\section{Verificação da Deformação}

Combinação rara : $F_{r a r a}=F_{g k}+F_{q k}$

Combinação quase permanente: $F_{\mathrm{d}, q f}=F_{g k}+0,2$ * $F_{q k}$

Critério de aceitação (NBR 6118):

\begin{tabular}{|c|c|c|c|}
\hline & $a_{t} \leq \frac{l}{300}$ & & $a_{i s} \leq \frac{l}{500}$ \\
\hline \multirow[b]{2}{*}{ Peça } & $M_{d, \text { rara }}(k N . c m)$ & $\begin{array}{l}\text { Estimativa das } \\
\text { flechas }(\mathrm{cm})\end{array}$ & $\begin{array}{c}\text { Critérios de aceitação } \\
(\mathbf{c m})\end{array}$ \\
\hline & $M_{c r}(k N . c m)$ & $\begin{array}{l}\text { Flecha para ações de } \\
\text { longa duração }\left(a_{t 1}\right) \\
\text { Flecha imediata }\left(a_{\text {is }}\right)\end{array}$ & $\begin{array}{l}\text { Flecha total }\left(a_{t}\right)^{*} \\
\text { Flecha imediata }\left(a_{i s}\right)\end{array}$ \\
\hline \multirow{2}{*}{ Degrau } & 22,3 & \multirow{2}{*}{$\begin{array}{l}a_{t \mid}=0,0027 \\
a_{\text {is }}=0,0023\end{array}$} & \multirow{2}{*}{$\begin{array}{l}a_{t}=0,40 \\
a_{i s}=0,24\end{array}$} \\
\hline & 60,5 & & \\
\hline \multirow{2}{*}{$\begin{array}{l}\text { Viga } \\
\text { Jacaré }\end{array}$} & 29,26 & \multirow{2}{*}{$\begin{array}{r}a_{t \mid}=0,010 \\
a_{i s}=0,0011\end{array}$} & \multirow{2}{*}{$\begin{array}{l}a_{t}=0,28 \\
a_{\text {is }}=0,17\end{array}$} \\
\hline & 41,3 & & \\
\hline \multirow{2}{*}{ Patamar } & 38 & \multirow{2}{*}{$\begin{array}{c}a_{t l}=0,06 \\
a_{\text {is }}=0,024\end{array}$} & \multirow{2}{*}{$\begin{array}{l}a_{t 1}=0,43 \\
a_{i s}=0,26\end{array}$} \\
\hline & 69,4 & & \\
\hline
\end{tabular}

Se $M_{d, \text { rara }}<M_{c r}$ a peça não está fissurada (estádio I).

$* a_{t}=a_{t \mid}+a_{\text {is }}$

Os limites aceitáveis para os Estados Limites de Utilização foram verificados também segundo as exigências contidas na proposta de revisão da ABNT (2000), NBR 6118. 


\section{Dimensionamento da ligação}

Segundo LEONHARDT \& MÖNNING (1978), um pino embutido no concreto assemelha-se a uma barra sobre apoio elástico.

\begin{tabular}{|l|c|}
\hline Ligação por Chumbadores & \\
\hline$F_{u}=1,27^{\star} \phi^{*}\left(f_{c k}{ }^{*} f_{\mathrm{yk}}\right)^{1 / 2}$ & $13,3 \mathrm{kN}$ \\
\hline $\mathrm{F}_{\mathrm{u}} / 5$ & $2,66 \mathrm{kN}$ \\
\hline $\mathrm{V}_{\mathrm{k}}$ - peça de apoio $\mathrm{n}^{0} 5$ & $2,24 \mathrm{kN}$ \\
\hline $\mathrm{V}_{\mathrm{k}}$ - viga jacaré & $3,45 \mathrm{kN}$ \\
\hline
\end{tabular}

* A força de cálculo da viga jacaré é maior que a força última permitida na parede; portanto, recomenda-se aumentar o diâmetro do chumbador para $15 \mathrm{~mm}$ (5/8"), ou aumentar o número de furos.

Distância mínima entre chumbadores: 10 申uro

Distância mínima entre chumbador e borda de concreto: 5 कchumbador

Comprimento de embutimento na parede: $10 \mathrm{~cm}$

A ligação parafusada é dimensionada de forma que a resistência de cálculo seja igual ou superior à solicitação, acrescidos os coeficientes de ponderação. O dimensionamento segue os critérios da ABNT (1986), NBR 8800, verificando-se a resistência a esforços de cisalhamento e ao esmagamento do parafuso.

Os coeficientes de resistência foram extraídos da NBR 8800 e são:

$$
\phi_{\mathrm{v}}=0,6 \quad \phi=0,75 \quad \alpha=3
$$

A área bruta do parafuso $\left(A_{p}\right)$ e a área efetiva para pressão de contato $\left(A_{b}\right)$ que serão utilizadas nas verificações, foram calculadas:

$A_{p}=\pi d^{2} / 4=1,26 \mathrm{~cm}^{2}$

$A_{b}=d_{p} * e_{c h}=1,25 * 4=5 \mathrm{~cm}^{2}$

A resistência à tração do aço $\left(\mathrm{f}_{\mathrm{u}}\right)$ do parafuso SAE 1010 equivale a $33 \mathrm{kN} / \mathrm{cm}^{2}$

\begin{tabular}{l}
\hline $\begin{array}{l}\text { Ligação por Parafusos } \\
\text { (NBR 8800/86) }\end{array}$ \\
\hline
\end{tabular}

\section{Ligação por Contato}

Verificação do cisalhamento do parafuso

\begin{tabular}{|l|l|l}
\hline$\phi_{v} \times R_{v}=\phi_{v} \times 0,42 \times A_{p} \times f_{u}$ & $0,6 \times 0,42 \times 1,26 \times 33$ & $10,5 \mathrm{kN} /$ parafuso \\
\hline
\end{tabular}

Verificação ao esmagamento

\begin{tabular}{|l|l|l}
\hline$\phi \times R_{n}=\phi \times \alpha \times A_{b} \times f_{u}$ & $0,75 \times 3 \times 5 \times 33$ & $371 \mathrm{kN}$
\end{tabular}

Diâmetro máximo do furo $=\mathrm{d}+1,5=14 \mathrm{~mm}$

Distância máxima às bordas $=15 \mathrm{~cm}$ 
D. Desenho final - Detalhamento

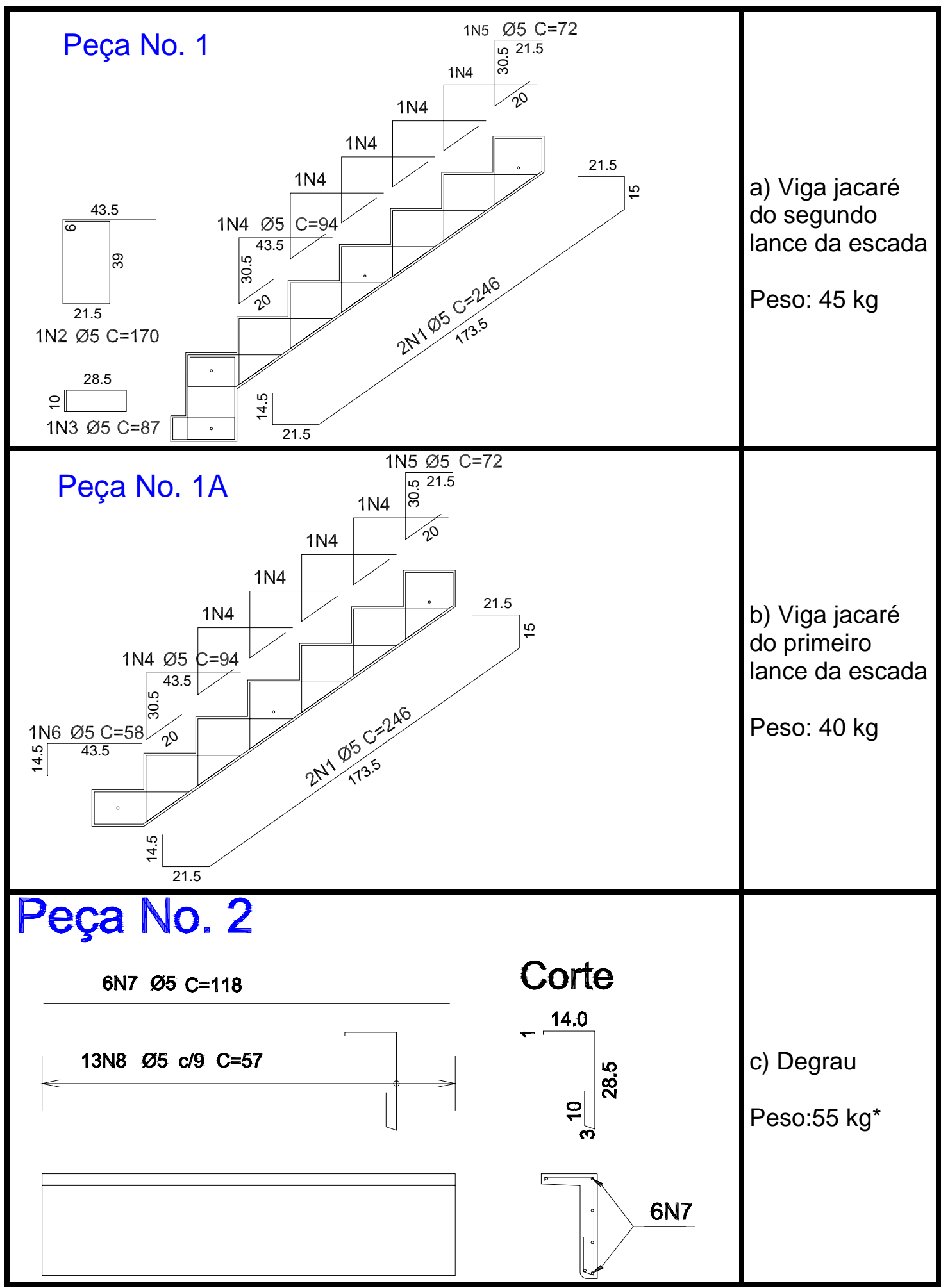

* Peça transportada por dois operários.

Figura 4.12: Vigas denteadas e degrau da escada pré-moldada jacaré (cortesia da TecSof Engenharia de Estruturas S/C Ltda) 


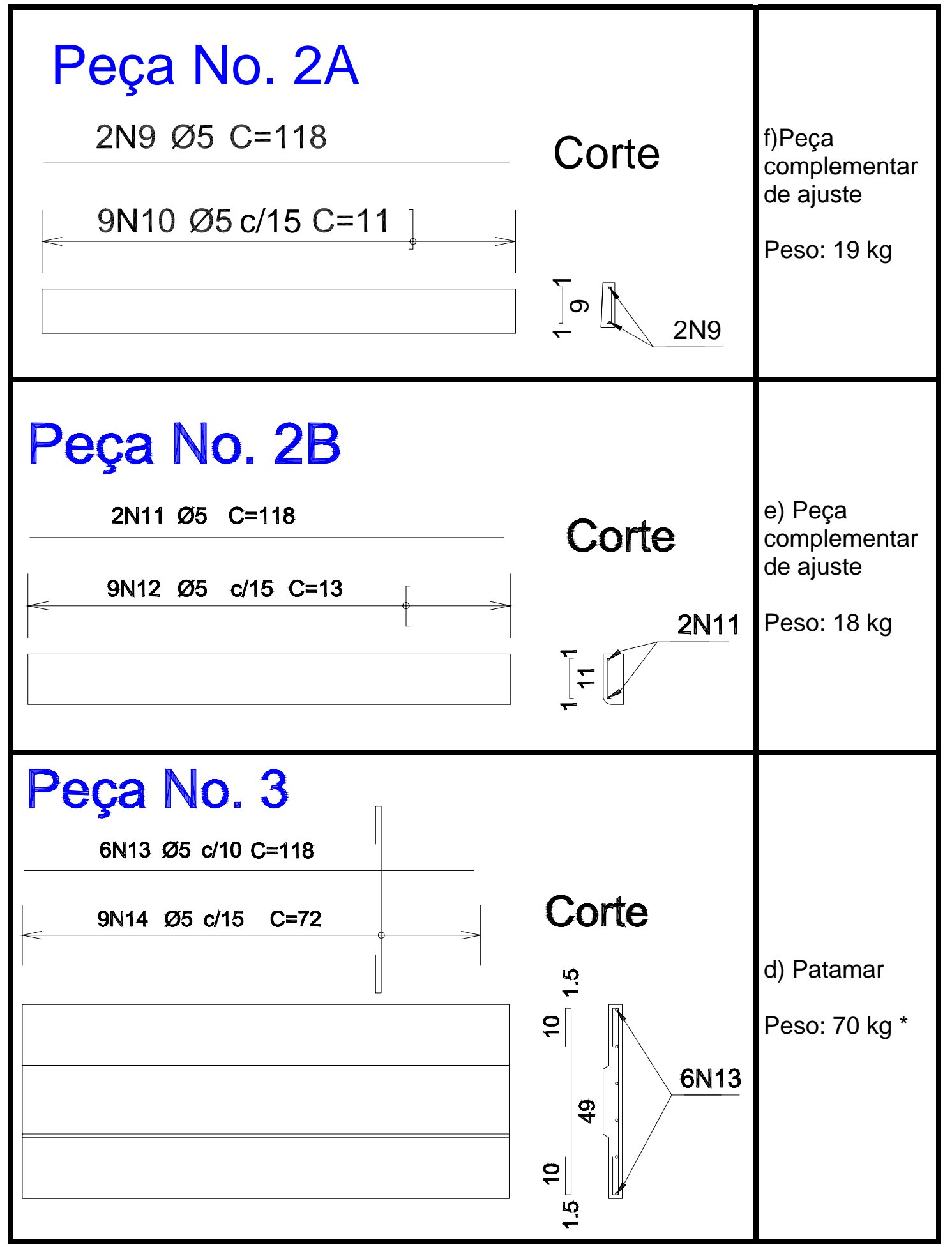

* Peça transportada por dois operários.

Figura 4.13: Patamar e peças complementares de ajuste da escada pré-moldada jacaré (cortesia da TecSof Engenharia de Estruturas S/C Ltda) 


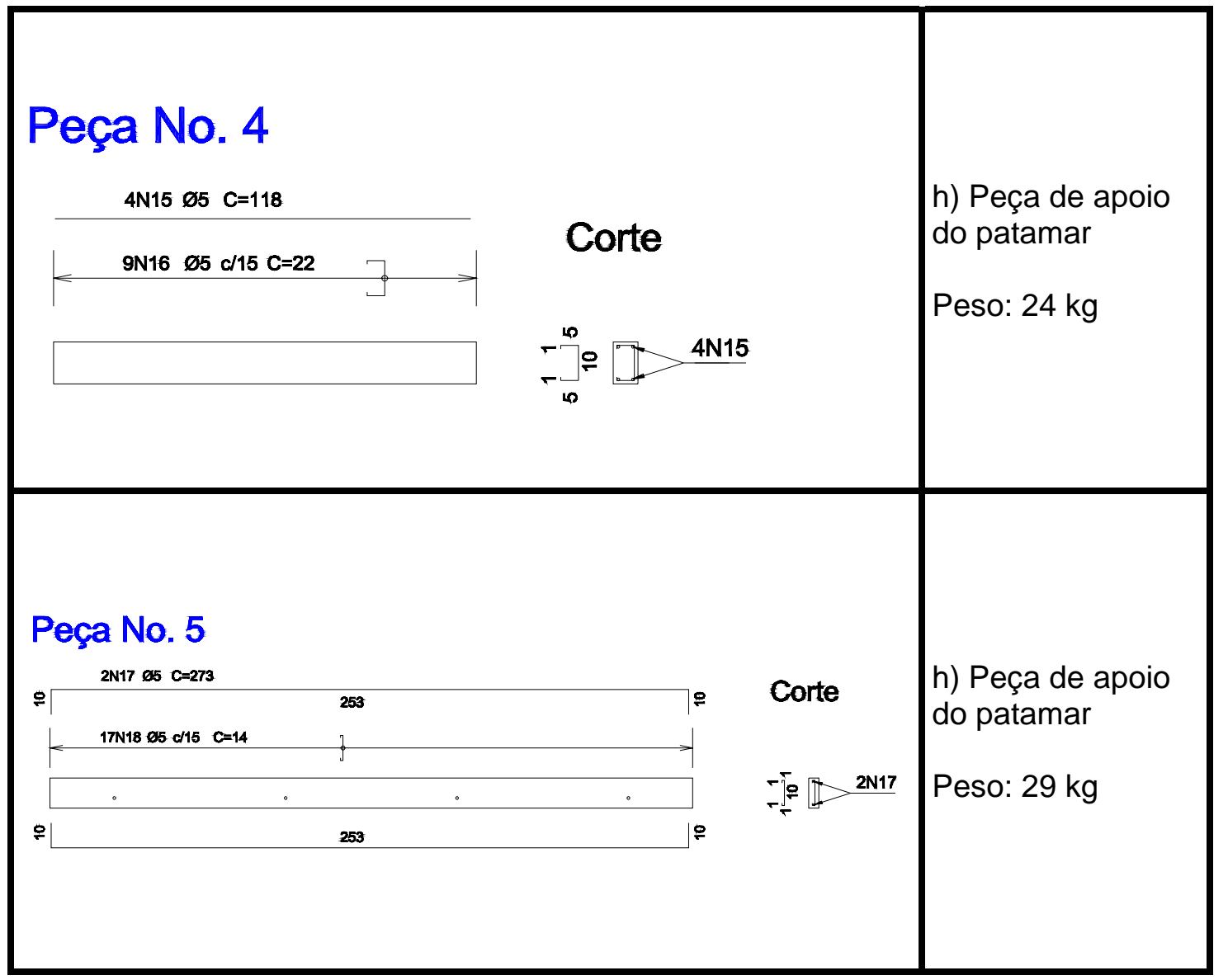

Figura 4.14: Peças de ajuste da escada pré-moldada jacaré (cortesia da TecSof Engenharia de Estruturas S/C Ltda)

As armaduras são simples e de fácil execução, como pode ser visto nas figuras $4.12,4.13$ e 4.14 .

Os critérios aplicados para o dimensionamento do concreto armado são bem aceitos para o cálculo estrutural das peças em argamassa armada. Os arranjos de detalhamento da armadura, no entanto, são particulares à argamassa armada e portanto, não é boa prática adaptar as recomendações estipuladas para o concreto.

O ideal seria a realização do dimensionamento experimental, com provas de cargas das peças em laboratórios especializados ou mesmo no próprio laboratório da obra. Contando com a produção de elevado número de peças, a prova de carga tornar-se-ia um atrativo, resultando na certeza do perfeito funcionamento do sistema. 
A prática vem mostrando que os arranjos apresentados nas figuras 4.12, 4.13 e 4.14 oferecem resultados satisfatórios.

Como pôde ser comprovado, o peso de todas as peças é compatível com a capacidade portante do operário, chegando-se a um máximo de $70 \mathrm{Kg}$ (patamar), e deve ser transportado por dois funcionários.

O exemplo apresentado da escada pré-moldada jacaré foi um estudo de caso; porém, a modulação vertical da alvenaria, com módulo fixo em $20 \mathrm{~cm}$ e a repetição de distâncias usuais de piso a piso, permitirão que, com pequenas adaptações, este exemplo se enquadre em vários projetos de escadas para edifícios em alvenaria estrutural.

A condição ideal para a implantação da escada jacaré está em construtoras que procuram padronizar suas edificações. Com isso, a altura do pavimento e os vãos da escada tornam-se uma constante e os elementos pré-moldados são reaproveitados em todas as edificações.

O exemplo de projeto para produção com ficha de procedimentos de execução está apresentado no Anexo A. 


\section{ABERTURAS}

s aberturas são interrupções na elevação da alvenaria, geralmente
para instalação de portas e janelas e são as causas de grandes interferências no processo de execução da alvenaria e no fluxo das tensões.

A coordenação modular entre as dimensões das aberturas na alvenaria e as dimensões das esquadrias geralmente não é tratada com a devida importância por empresas de pequeno e médio porte. O resultado da falta de compatibilidade entre os componentes é o ajuste dimensional com o preenchimento improvisado dos vazios, comprometendo a racionalização do processo, a qualidade da construção e, em muitos casos, o desempenho estrutural.

No aspecto estrutural, as aberturas desviam o encaminhamento das tensões para as paredes adjacentes, provocando a concentração delas nos cantos.

As vergas e contravergas são os elementos responsáveis por absorverem as tensões concentradas dos cantos; além de, no caso das vergas, desviarem as forças por mecanismo de flexão. Se não consideradas adequadamente no cálculo estrutural, as tensões concentradas e as forças atuantes sobre as aberturas podem resultar em patologias indesejáveis, como as fissuras. 


\subsection{Esquadrias}

As esquadrias constituem uma parcela significativa do custo total da edificação, podendo alcançar uma parcela de $9 \%{ }^{1}$, e no entanto, não são tratadas com a importância que se deveria, resultando em procedimentos executivos não racionalizados, com quebras de blocos e enchimentos posteriores.

Adotar procedimentos executivos racionalizados que compatibilizem o uso das esquadrias padronizadas com a modulação da alvenaria é uma solução para amenizar os custos e melhorar a qualidade.

Esquadrias padronizadas são aquelas comercialmente encontradas no mercado, produzidas em série, com controle de processo, padrão de qualidade definido e economia de escala, o que permite oferecer ao consumidor preços competitivos.

A ABNT (1981), NBR 5722 e NBR 5728 recomenda que as portas e as janelas, com suas guarnições, tenham largura e altura modulares e que os detalhes modulares devem ser projetados para absorver os problemas com erros de execução na obra, como montagem, encaixe ou sobreposições.

No entanto, as normas de dimensões modulares não são seguidas pelos fabricantes dos componentes de vedação. Segundo EICKHOFF (1997), "os fabricantes acreditam que seriam necessários grandes investimentos para adequar a sua produção para as dimensões normalizadas".

Cabe aos construtores, portanto, desenvolverem procedimentos de instalação dos componentes das esquadrias para contornarem de forma racionalizada a falta de compatibilidade entre o subsistema de vedação e de alvenaria.

Para o estudo da coordenação dimensional entre as esquadrias e as aberturas na alvenaria modular, é necessário conhecer em detalhes as esquadrias

\footnotetext{
${ }^{1}$ Informação pessoal obtida pela autora em entrevista a construtoras.
} 
e as técnicas para sua instalação e ter em mente, os fundamentos da modulação da alvenaria, cujos conceitos foram apresentados no capítulo 3 deste trabalho.

Este item tem como objetivo apresentar os materiais constituintes e os procedimentos de instalação das esquadrias em edifícios de alvenaria estrutural. A partir de breve caracterização, será viável uma avaliação da melhor solução a adotar e até prever, quando necessário, ajustes dimensionais, de modo que sejam feitos racionalmente.

Os procedimentos para a instalação das esquadrias aqui descritos estão baseados em análises do que tem sido executado atualmente nas construções e em informações dos fabricantes.

\subsubsection{Portas}

Portas são componentes da edificação formados por batente (marco), guarnição e folha.

O batente pode ser confeccionado em madeira, alumínio ou em chapa dobrada de aço galvanizado e é o elemento fixo que guarnece o vão da parede onde se prende a folha da porta. Ele tem um rebaixo contra o qual a folha da porta se fecha. A guarnição é fixada ao batente e arremata a porta junto à parede. A folha é a parte móvel da porta e pode ser fabricada em madeira, alumínio e aço, entre outros materiais como o vidro, o acrílico, etc.

Nos edifícios habitacionais são comumente empregadas portas com folhas em madeira, variando-se o material constituinte do batente em: madeira, aço e alumínio. Os batentes podem estar chumbados à alvenaria ou envolvendo-a.

Dependendo do material que compõe a folha ou o batente da porta, haverá especificações diferentes quanto à abertura necessária para a fixação da esquadria.

Na tabela 5.1, são mostradas as alturas de portas industrializadas, com as dimensões padrões, usualmente encontradas no mercado brasileiro. Na mesma tabela, é considerada a espessura do piso acabado e é calculado o ajuste existente entre as esquadrias e o vão vertical da parede. 
A espessura total do piso acabado de $3 \mathrm{~cm}$, corresponde ao contrapiso de regularização e revestimento com piso cerâmico.

Tabela 5.1: Altura $(\mathrm{cm})$ de portas padronizadas e ajustes com relação à modulação da alvenaria estrutural.

\begin{tabular}{|l|c|c|c|c|}
\hline Material & $\begin{array}{c}\text { Altura da } \\
\text { Folha } \mathbf{( c m )}\end{array}$ & $\begin{array}{c}\text { Espessura } \\
\text { do piso } \\
\text { acabado } \mathbf{( c m})\end{array}$ & $\begin{array}{c}\text { Espessura do } \\
\text { batente } \mathbf{( c m )}\end{array}$ & $\begin{array}{c}\text { Ajuste } \\
\mathbf{( c m})\end{array}$ \\
\hline Folha e batente de madeira & 211 & 3 & 3 & 4 \\
\hline $\begin{array}{l}\text { Folha de madeira e batente } \\
\text { metálico envolvente }\end{array}$ & 211 & 3 & - & 7 \\
\hline Alumínio & 210 & 3 & - & 8 \\
\hline Aço & $217^{*}$ & - & - & 3 \\
\hline
\end{tabular}

${ }^{*}$ Altura da porta incluindo a espessura do contrapiso.

Para o cálculo do ajuste, considera-se a abertura vertical na alvenaria com altura modular de $220 \mathrm{~cm}$ mais $1 \mathrm{~cm}$ de junta $(221 \mathrm{~cm})$.

As larguras padronizadas das folhas das portas industrializadas são: 60 , $62,70,72,80,82,90$, e $92 \mathrm{~cm}$.

O ideal para reduzir os custos de portas é adotar as esquadrias padronizadas; porém, nem sempre as dimensões apresentadas pelos fabricantes, são compatíveis com a modulação da alvenaria, obrigando a existência de ajustes dimensionais.

O ajuste dimensional dependerá do tipo de esquadria e do procedimento adotado para a instalação das portas, considerando-se as juntas.

\subsubsection{Procedimentos Executivos para Instalação de Portas de Madeira}

Serão descritos três procedimentos executivos para instalação das portas com folhas de madeiras, com soluções de ajustes dimensionais altimétricos e planimétricos para compatibilizar as portas oferecidas no mercado atual com a modulação da alvenaria.

Os procedimentos descritos não prevêem a quebra dos blocos ou o corte das folhas; também não é indicado o assentamento com a argamassa solidarizada (faceando) à madeira, pois segundo indicação do fabricante de portas, a umidade da argamassa pode causar o empenamento da madeira. 
Espuma de Poliuretano: O quadro da porta deve estar alinhado, nivelado, no prumo e encunhado nas laterais em três pontos com espaçamento de aproximadamente $1,5 \mathrm{~cm}$ da alvenaria. Aplicar a espuma de poliuretano, conforme indicações do fabricante, entre a parede e o batente, nos extremos (a $20 \mathrm{~cm}$ da extremidade) e no meio das laterais. Após a cura do poliuretano, cerca de 4 a 8 horas, cortar as sobras, retirar as travas de suporte da porta e as cunhas. Fixar as guarnições para o acabamento (figura 5.1).

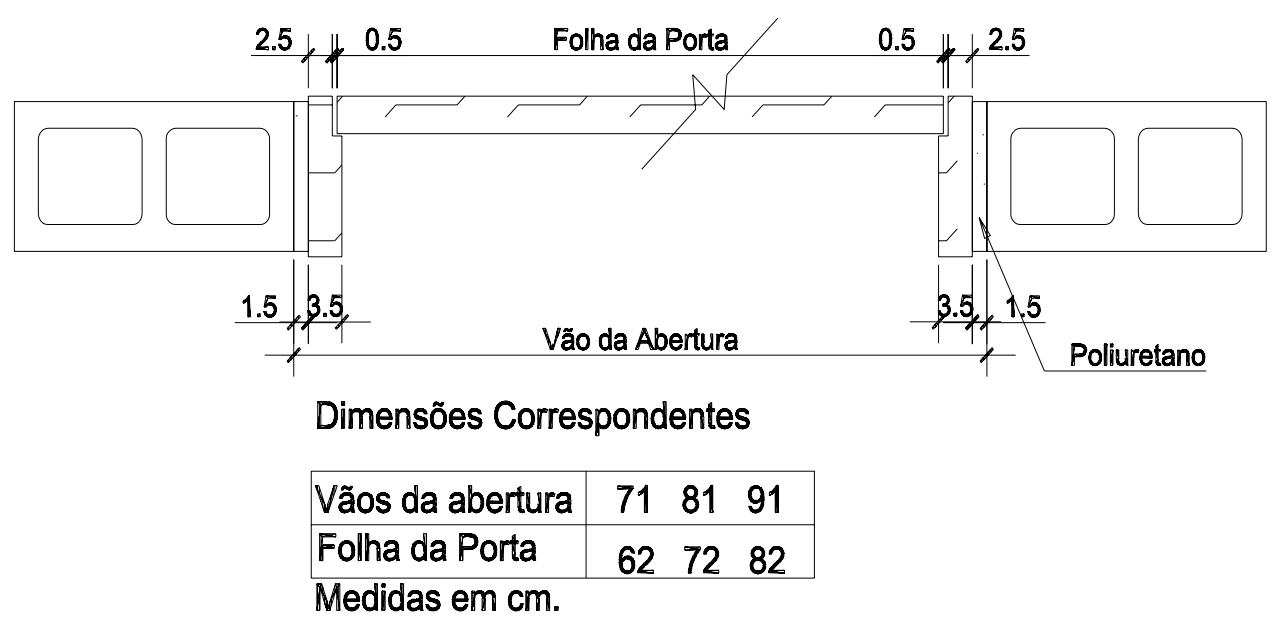

Figura 5.1: Esquema para instalação de portas com batentes de madeira com uso de espuma de poliuretano

Para o ajuste altimétrico, sugere-se o uso de vergas pré-moldadas com altura de $22 \mathrm{~cm}$, como ilustrado na figura 5.2 . 


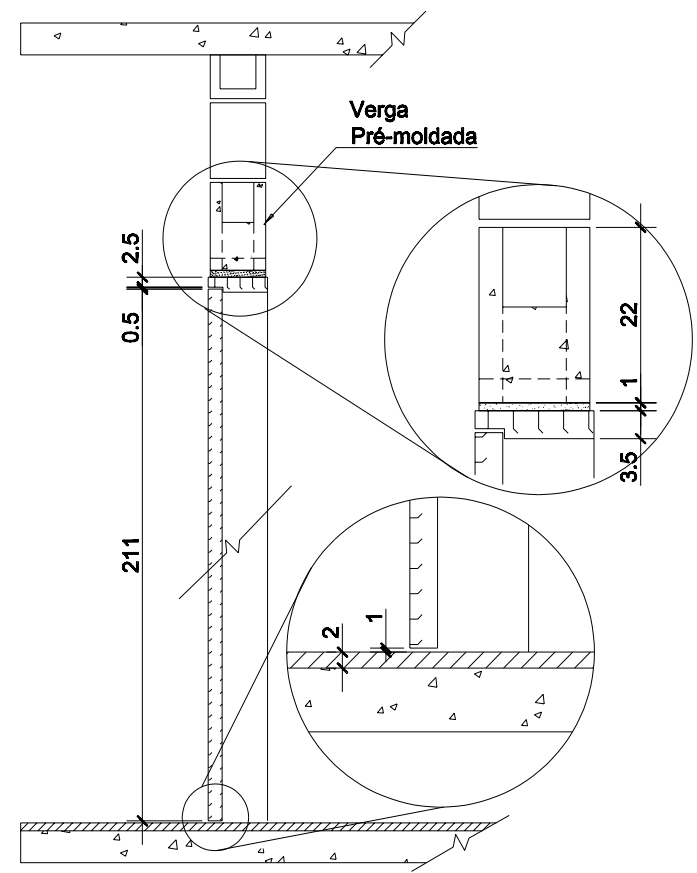

Figura 5.2: Esquema para instalação de portas com batentes de madeira com acerto da modulação altimétrica

Tacos e Parafusos: Chumbar três tacos de madeira na parede de cada lado, distribuídos a $20 \mathrm{~cm}$ da extremidade e ao centro, para receber os parafusos de fixação dos batentes. Deixar espaço entre a parede e o batente de, no mínimo, $1 \mathrm{~cm}$, e no máximo, $1,5 \mathrm{~cm}$, para cada lado. Colocar calços entre os tacos e o batente e fixar o batente com parafusos apenas do lado das dobradiças, mantendo-se prumo, nível e esquadro. É importante que não haja vazio algum entre os calços e o batente. Colocar duas dobradiças a $20 \mathrm{~cm}$ dos extremos e uma no meio da folha da porta e parafusá-la no batente. Deste modo, a folha serve de gabarito na fixação do restante do batente. Parafusar o restante do batente nos calços e tacos (figura 5.3). 


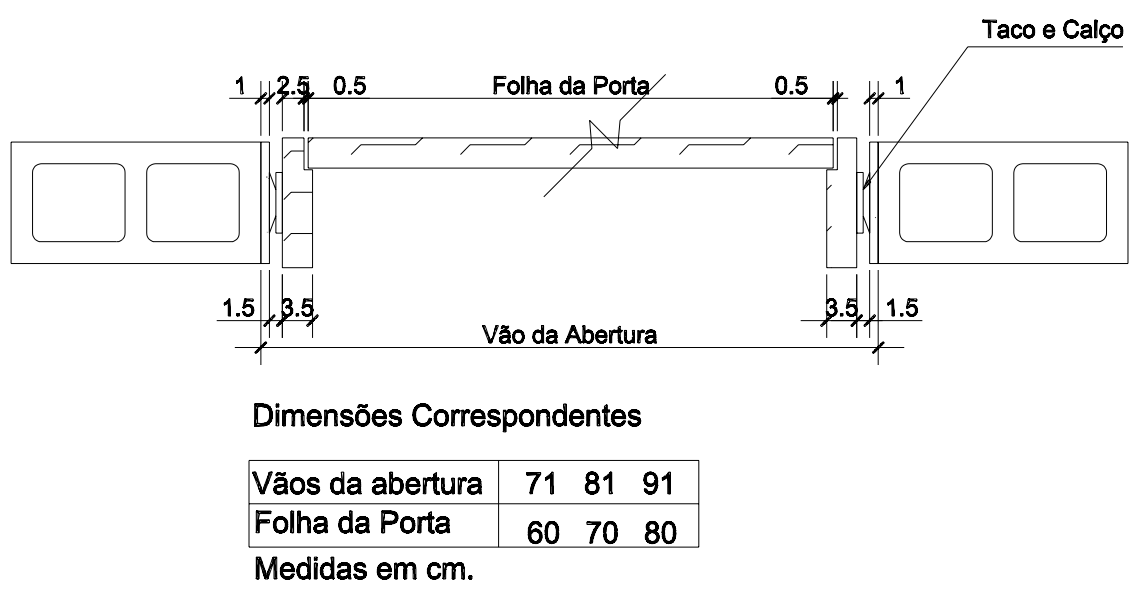

Figura 5.3: Esquema para instalação de portas com batentes de madeira com tacos e parafusos

O ajuste altimétrico sugerido é semelhante ao anterior (figura 5.2), com verga pré-moldada.

Batente metálico envolvente: Elevar castelos de três fiadas de blocos nas posições que delimitam a abertura do vão da porta. Posicionar o pórtico metálico no vão e escorá-lo provisoriamente durante o início da sua fixação. Verificar o acerto geométrico, o nível e o prumo. Chumbar o batente envolvente na alvenaria com argamassa de assentamento aplicada entre a "perna" do batente e a alvenaria, a cada fiada de assentamento de blocos. Retirar o escoramento após 24 horas do preenchimento da argamassa. O batente envolvente, quando devidamente marcado, pode servir de referência de prumo e nível para o assentamento do restante da alvenaria.

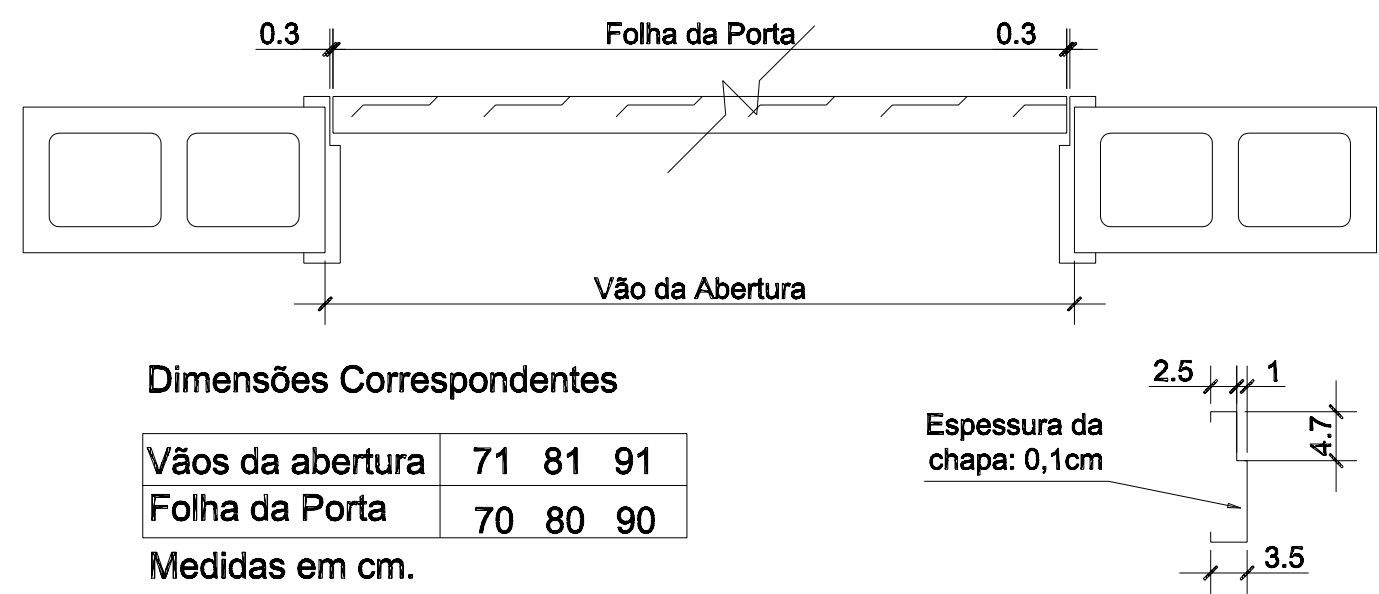

Figura 5.4: Esquema para instalação de batente metálico envolvente 
O contramarco envolvente permite regulagem de $4 \mathrm{~cm}$ no vão horizontal da porta e de $2 \mathrm{~cm}$ no vertical, apenas variando-se o embutimento do bloco na parede.

Figura 5.5: Esquema para instalação de batentes metálicos envolventes com acerto da modulação altimétrica

Batente metálico não envolvente: Posicionar o batente metálico no vão e verificar o acerto geométrico, o nível e o prumo. Parafusar o perfil metálico diretamente na alvenaria com o auxilio de buchas. Para evitar que a atividade de parafusar danifique o perfil metálico, recomenda-se colocar calços limitadores para o aperto do parafuso.

Os batentes metálicos são fornecidos por encomenda, com dimensões estabelecidas pelo comprador, o que permite que o ajuste dimensional planimétrico seja incorporado à própria dimensão do batente.

O ajuste altimétrico sugerido também é com auxílio da verga pré-moldada; porém, com altura da verga definida a partir das dimensões da espessura do batente. 
Os procedimentos executivos são descritos para instalação de portas, a partir do piso acabado. Se o piso estiver no nível da laje, devem-se providenciar calços com a altura do contrapiso para a parte inferior do batente.

A escolha do tipo de batente deve ser feita considerando-se as principais vantagens e desvantagens de cada um, listadas na tabela 5.2. 
Tabela 5.2: Quadro comparativo de vantagens e desvantagens entre portas com batentes metálicos e de madeira.

\begin{tabular}{|c|c|}
\hline \multirow{4}{*}{ 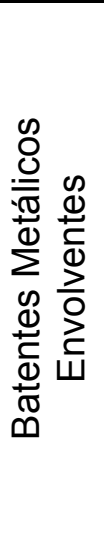 } & Vantagens \\
\hline & $\begin{array}{l}\text { - Rigidez do pórtico (montantes e travessas), facilitando a instalação; } \\
\text { - Colocação anterior à execução da alvenaria; } \\
\text { - Uso dispensável da guarnição; } \\
\text { - Colocação do batente em uma só fase; } \\
\text { - Utilização como guia para execução da alvenaria; } \\
\text { - Possibilidade de ajuste no nível do piso acabado e com isso, o acerto da } \\
\text { modulação altimétrica. }\end{array}$ \\
\hline & Desvantagens \\
\hline & $\begin{array}{l}\text { - Possibilidade de corrosão; } \\
\text { - Necessidade de escoramento provisório durante fixação; } \\
\text { - Fornecimento de batentes por encomenda. }\end{array}$ \\
\hline \multirow{4}{*}{ 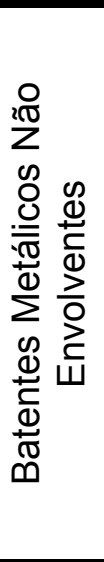 } & Vantagens \\
\hline & $\begin{array}{l}\text { - Facilidade de instalação das folhas (montantes e travessas já montados e } \\
\text { travados); } \\
\text { - Dispensa do uso da guarnição, } \\
\text { - Não interferência da linha do pedreiro durante a execução da alvenaria; } \\
\text { - Possibilidade do ajuste dimensional na espessura do batente. }\end{array}$ \\
\hline & Desvantagens \\
\hline & $\begin{array}{l}\text { - Impossibilidade de utilização como guia para a execução da alvenaria; } \\
\text { - Colocação após a execução da alvenaria, dificultando a fixação de maneira } \\
\text { racionalizada; } \\
\text { - Possibilidade de corrosão; } \\
\text { - Fornecimento por encomenda. }\end{array}$ \\
\hline \multirow{4}{*}{ 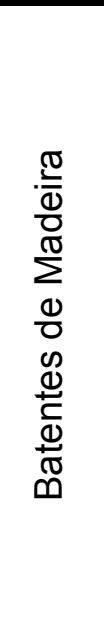 } & Vantagens \\
\hline & $\begin{array}{l}\text { - Facilidade de ajuste na obra; } \\
\text { - Aceitação já tradicional do uso; } \\
\text { - Utilização como guia para execução dos revestimentos; } \\
\text { - Facilidade de adaptação aos modelos fornecidos comercialmente para a } \\
\text { modulação da alvenaria. }\end{array}$ \\
\hline & Desvantagens \\
\hline & $\begin{array}{l}\text { - Não modular à altura da alvenaria; } \\
\text { - Suscetível a empenamentos; } \\
\text { - Dependente de intensa verificação do esquadro do conjunto; } \\
\text { - Facilidade de danos por choques durante a construção; } \\
\text { - Necessidade de emprego das guarnições; } \\
\text { - Complexidade maior no assentamento quando comparado com os batentes } \\
\text { envolventes. }\end{array}$ \\
\hline
\end{tabular}




\subsubsection{Janelas}

Janela é uma classe de esquadria, geralmente envidraçada, destinada a preencher um vão, em fachadas ou não. Ela é um componente da edificação composto por batente (marco) e folhas que controlam o fechamento de um vão à iluminação e à ventilação (YAZIGI, 1998).

São encontradas janelas de madeira, PVC, aço ou alumínio. Nos edifícios habitacionais, são comumente empregadas as de alumínio e de aço, esta última em menor proporção. Elas podem ser adquiridas prontas no mercado consumidor, conhecidas como padronizadas, ou por encomenda.

As padronizadas encontradas no mercado saem da fábrica com o acabamento final, inclusive com a presença do vidro e envolvidas por uma embalagem rígida, de eucatex, que as protege contra danos ou respingos de argamassa ou tinta. $O$ produto chega na obra, pronto para a instalação, sem o contramarco.

As esquadrias feitas por encomenda geralmente são compostas por marco e contramarco e devem ter dimensões compatíveis com as aberturas na alvenaria e com o procedimento executivo adotado. Dependendo da quantidade de unidades necessárias, elas podem vir a ser fabricadas pelas indústrias de esquadrias.

As dimensões das esquadrias devem ser especificadas a partir do procedimento executivo adotado; porém, sempre respeitando-se as delimitações impostas pela modulação na alvenaria.

O vão das aberturas, em concordância com os conceitos da modulação, possui dimensão equivalente a:

$$
\begin{gathered}
n \times M+1 \mathrm{~cm} \\
\mathrm{n}=\mathrm{n}^{\text {o. }} \text { múltiplo de módulos } \\
\mathrm{M}=\text { valor do módulo adotado }
\end{gathered}
$$




\subsubsection{Procedimentos Executivos para Instalação de Janelas de Alumínio}

Seguindo o mesmo raciocínio feito para as portas, tentar-se-á descrever alguns procedimentos executivos racionalizados para instalação de janelas de alumínio, sem a quebra de blocos e visando eliminar enchimentos posteriores.

\section{Instalação Sem Contramarco}

A instalação sem o contramarco pode ser feita com aplicação da espuma de poliuretano ou por intermédio das esquadrias padronizadas.

A instalação com espuma de poliuretano requer também uma fixação mecânica, com parafuso e bucha. A fixação com parafuso, diretamente na alvenaria, manterá a esquadria posicionada até a cura do poliuretano e garantirá a segurança contra a queda em caso de incêndio, quando a espuma desapareceria na presença das primeiras chamas.

Para a instalação da esquadria sem o contramarco, o vão da alvenaria precisa ser regular, com planicidade e prumo. Para tanto, é boa prática realizar o requadro do vão. A execução do requadro é facilitada com auxílio de um gabarito metálico, ilustrado na figura 5.6. O gabarito, envolvente à parede, também facilita a execução dos revestimentos internos e externos, além de possibilitar a moldagem da pingadeira na região do peitoril.

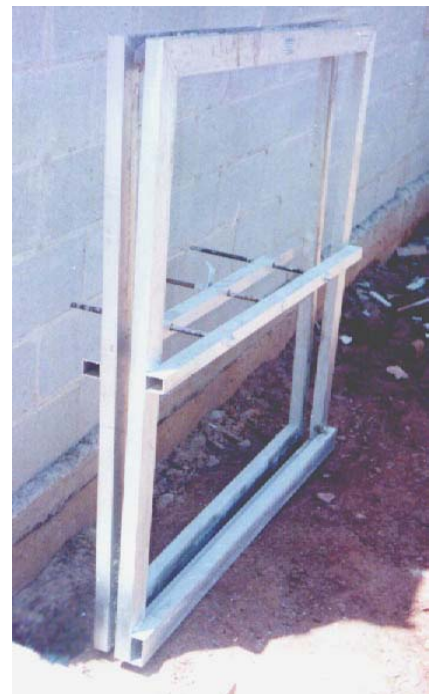

Figura 5.6: Gabarito metálico usado para o requadro do vão da alvenaria 
Na fase final da obra, após a execução dos revestimentos, o gabarito é retirado e a esquadria é nivelada, aprumada e fixada com parafuso e espuma de poliuretano, aplicada pela face externa da parede.

Recomenda-se prever uma distância entre a janela e a parede de $1 \mathrm{~cm}$.

O poliuretano requer mão-de-obra qualificada para sua aplicação, pois a expansão demasiada chega a danificar o perfil de alumínio.

Após a cura da espuma, cerca de 4 a 8 horas, é necessário cortar o excesso e fixar uma guarnição de proteção aos raios UV, que degradam o poliuretano. Uma proteção de borracha é suficiente.
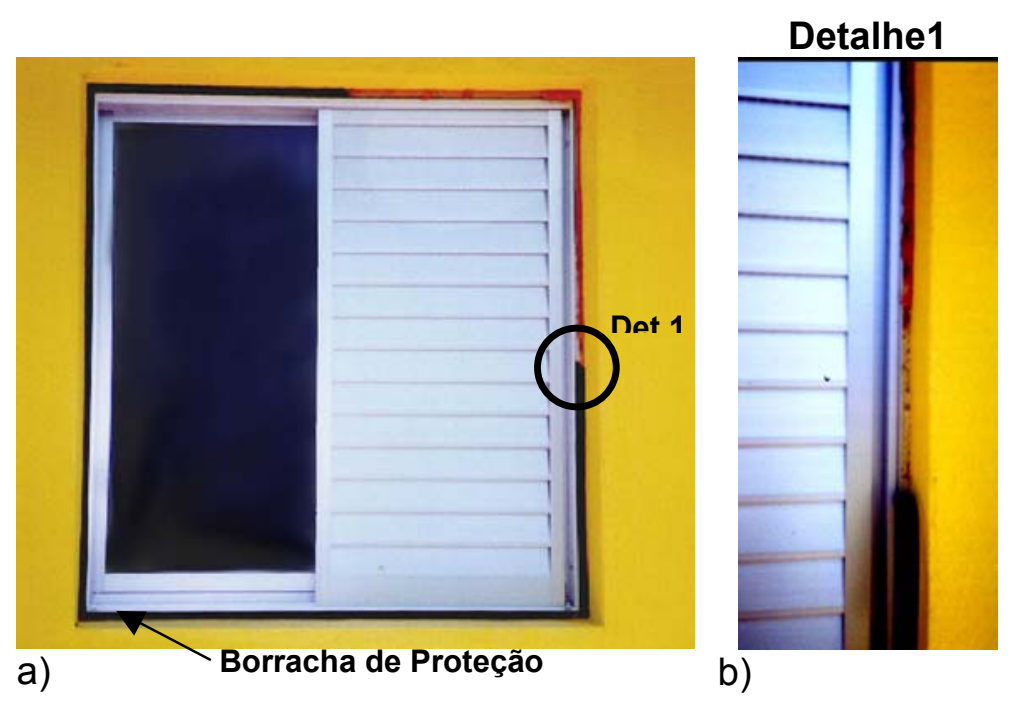

Figura 5.7: Borracha de proteção da espuma de poliuretano [a]; e degradação do poliuretano exposto aos raios UV [b] (cortesia de eng. Marson-YKK do Brasil Itda)

Outro procedimento de instalação sem o contramarco, é com o emprego das esquadrias padronizadas, ilustradas na figura 5.8 .

O fabricante recomenda: abrir as grapas que serão chumbadas; posicionar a peça no lugar observando as indicações do lado correto (interno e externo); verificar o prumo e o nível da peça, chumbar as grapas embutidas nos blocos e preencher os vazios com argamassa.

No entanto, este procedimento é condenado neste trabalho por exigir a quebra de blocos e prejudicar a racionalização do processo. 
Foi observado que os construtores contornam o problema da quebra dos blocos com o uso de grapas metálicas independentes, parafusadas por uma de suas extremidades ao perfil da janela. A outra extremidade é fixada por parafuso diretamente na alvenaria externa ou por pino, utilizando revólver de pressão. Fica por conta do revestimento externo, cuja espessura mínima é de $2,5 \mathrm{~cm}$, encobrir as grapas metálicas, protegendo-as. Se o revestimento interno possuir espessura suficiente para encobri-las, as grapas também poderão fixar-se internamente.

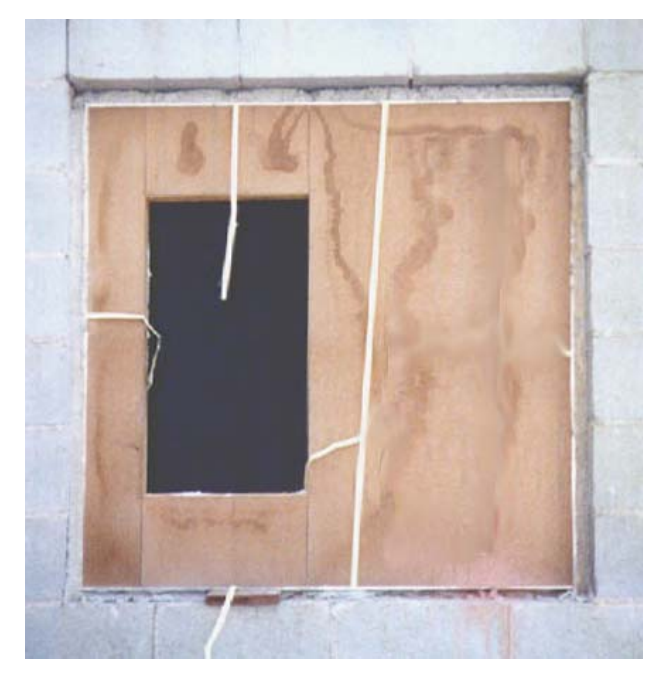

\section{Detalhe de fixação da grapa}

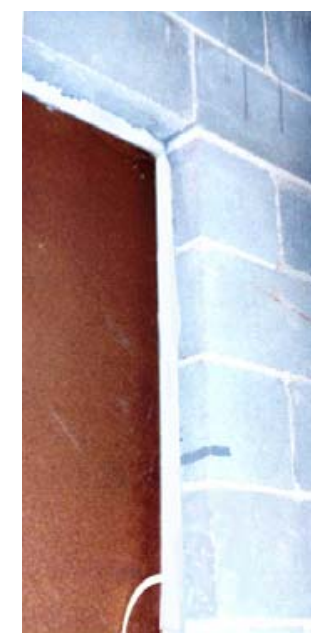

Figura 5.8: Foto da esquadria padronizada instalada vista externamente à edificação [a]; e detalhe do chumbamento da grapa [b]

As dimensões de caixilhos de alumínio padronizados apresentam valores dimensionais exatos, por exemplo, $120 \mathrm{~cm}$ de altura por $120 \mathrm{~cm}$ de largura. Considerando-se a abertura do vão da alvenaria (121 cm em osso), chega-se a um ajuste dimensional de $1 \mathrm{~cm}$ que, segundo técnicos especializados, é o suficiente para a instalação da esquadria. Para casos como este, o enchimento dos vazios em argamassa terá espessura de $0,5 \mathrm{~cm}$ de cada lado.

Com janelas cujas dimensões não são modulares com a alvenaria, como por exemplo, $150 \mathrm{~cm}$ de largura, podem-se adotar soluções alternativas, como o uso de peças compensadoras pré-moldadas de ajuste dimensional. Estes casos especiais serão tratados no item 5.5.3. 
A proteção rígida de eucatex das esquadrias padronizadas só será retirada após a execução do acabamento final (pintura das paredes ou assentamento de revestimento cerâmico).

A iluminação dos ambientes em que as janelas padronizadas já se encontram instaladas é garantida por aberturas na proteção rígida que permitem a passagem dos raios solares. No entanto, em tipos de janelas, como as basculantes ou maxim-ar, que não possuem essas aberturas falta iluminação que se agrava em determinados ambientes como em banheiros e cozinhas, onde a claridade é fundamental para a finalização do chamado acabamento fino (revestimento cerâmico).

\section{Instalação com Contramarco de Alumínio}

A função básica do contramarco é garantir que os vãos das aberturas tenham dimensões confiáveis, dentro das tolerâncias dimensionais do marco da janela.

As esquadrias padronizadas encontradas no mercado não possuem o contramarco; portanto, apenas aquelas feitas por encomenda se enquadram neste procedimento executivo.

Os contramarcos de alumínio podem ser chumbados com grapas ou parafusados diretamente na alvenaria.

O procedimento para chumbar com grapas é muito parecido com o previamente descrito para a fixação das esquadrias padronizadas. Inicialmente, as grapas são abertas e o contramarco é posicionado no vão; verifica-se o prumo e o nível da peça e fixam-se as grapas na alvenaria com parafuso ou revólver de pressão; a seguir, os vazios de interface contramarco-alvenaria são preenchidos com argamassa.

Também nesse caso, o revestimento externo, ou interno, deverá encobrir as grapas, protegendo-as e ajudando na fixação. 
Depois do acabamento final das paredes, com pintura ou revestimentos cerâmicos, instalam-se as janelas, parafusando-as ou apenas encaixando-as no perfil do contramarco.

Outra possibilidade de fixação do contramarco metálico é parafusando-o diretamente na alvenaria, como ilustrado na figura 5.9. No entanto, as dimensões do contramarco e do vão da abertura devem possuir o mínimo valor de ajuste.

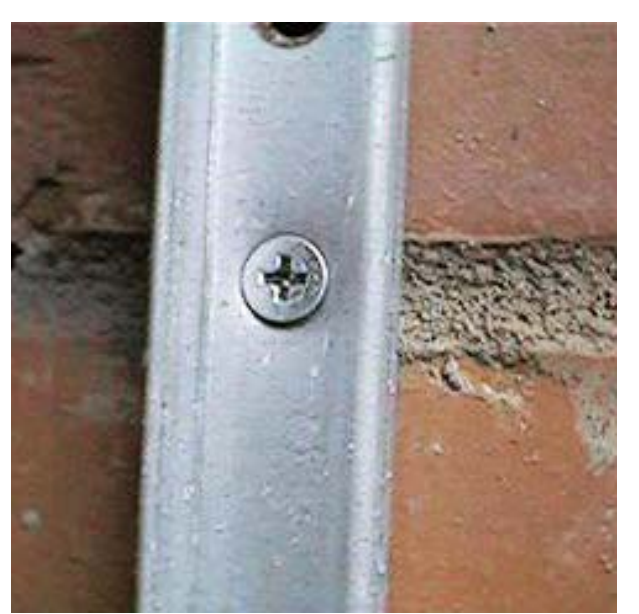

a) contramarco parafusado na alvenaria

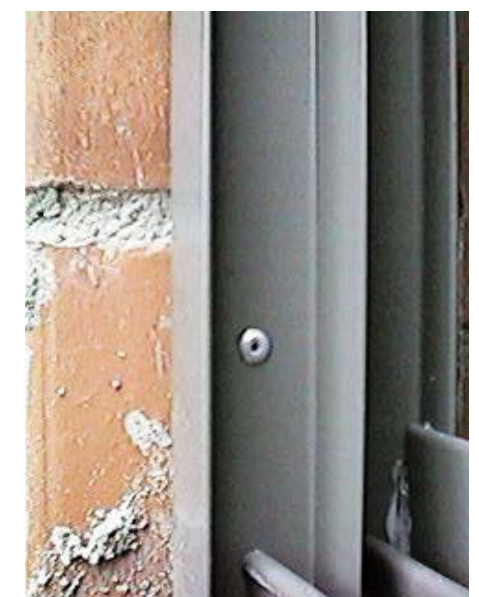

b) marco rebitado ao contramarco

Figura 5.9: Contramarco parafusado diretamente na alvenaria [a]; e marco rebitado ao contramarco [b]

O parafuso deve ser rosqueado com cautela para não entortar o perfil do contramarco. É recomendável o auxílio de um calço limitador.

A instalação da janela por parafuso diretamente na alvenaria, mantém a interface bloco-esquadria sem vedação, o que propicia a infiltração de água e vento. Esta vedação pode ser realizada com filme de silicone neutro ou com mastique.

Para melhorar o desempenho na estanqueidade das esquadrias, pingadeiras pré-moldadas surgem como uma solução alternativa, como ilustrado na figura 5.10. As pingadeiras contam com rebaixos, frisos, saliências e inclinações na seção transversal; seu uso é previsto em conjunto com blocos compensadores, de modo que o ajuste modular altimétrico seja garantido. 


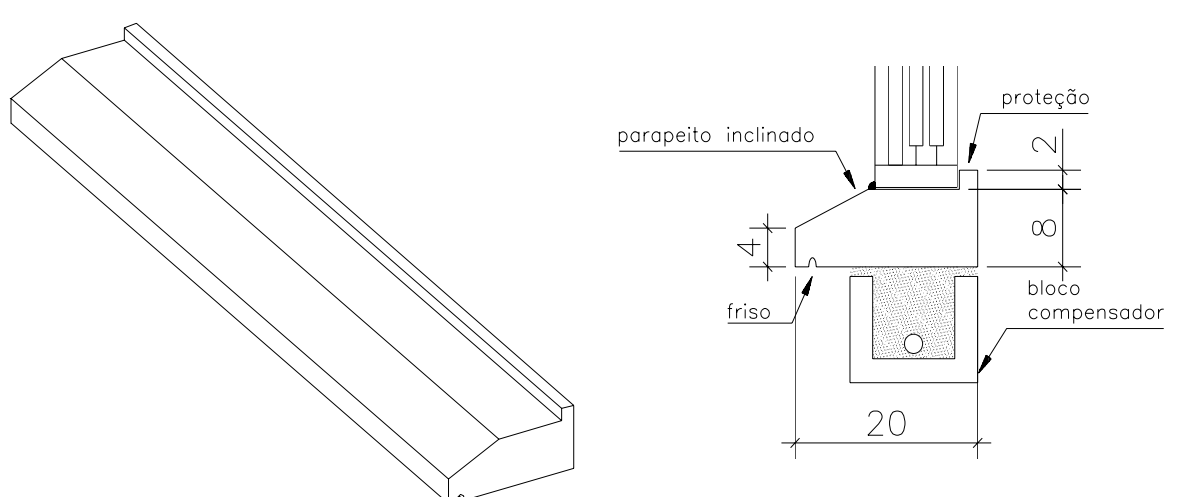

Figura 5.10: Pingadeira pré-moldada

\section{Instalação com Contramarco Pré-moldado}

O contramarco pré-moldado é um elemento delgado formado por concreto de granulometria fina que constituirá um quadro rígido envolvente à parede, no qual é fixada a janela.

Assim como os blocos, o contramarco é assentado durante a elevação da alvenaria com juntas de argamassa, não interrompendo o serviço e, se devidamente escorado, serve de apoio para o assentamento dos blocos constituintes da verga.

Os contramarcos exercem a função de requadrar o vão e de melhorar a estanqueidade das esquadrias; portanto, devem ter dimensões regulares e seções transversais com detalhes de pingadeira, rebaixos e saliências.

As janelas podem ser fixadas ao contramarco com poliuretano ou com parafuso, sentido de dentro para fora da edificação.

A instalação da janela com espuma de poliuretano requer também uma fixação mecânica com parafuso. A proteção da espuma contra os raios UV é garantida pelo próprio perfil do contramarco.

Como o próprio contramarco melhora a estanqueidade do sistema de vedação, as janelas podem estar apenas parafusadas, no entanto, para a garantia de total vedação é recomendável aplicar uma película impermeabilizante na interface do concreto com a janela metálica, que pode ser de silicone neutro. 
Por apresentar detalhes específicos, tanto de produção como de instalação, os contramarcos pré-moldados serão discutidos com mais detalhes em um item próprio neste mesmo capítulo (item 5.4).

Um resumo esquemático dos procedimentos executivos de instalação de esquadrias de alumínio, descritos no decorrer do texto, é apresentado na figura 5.11 .

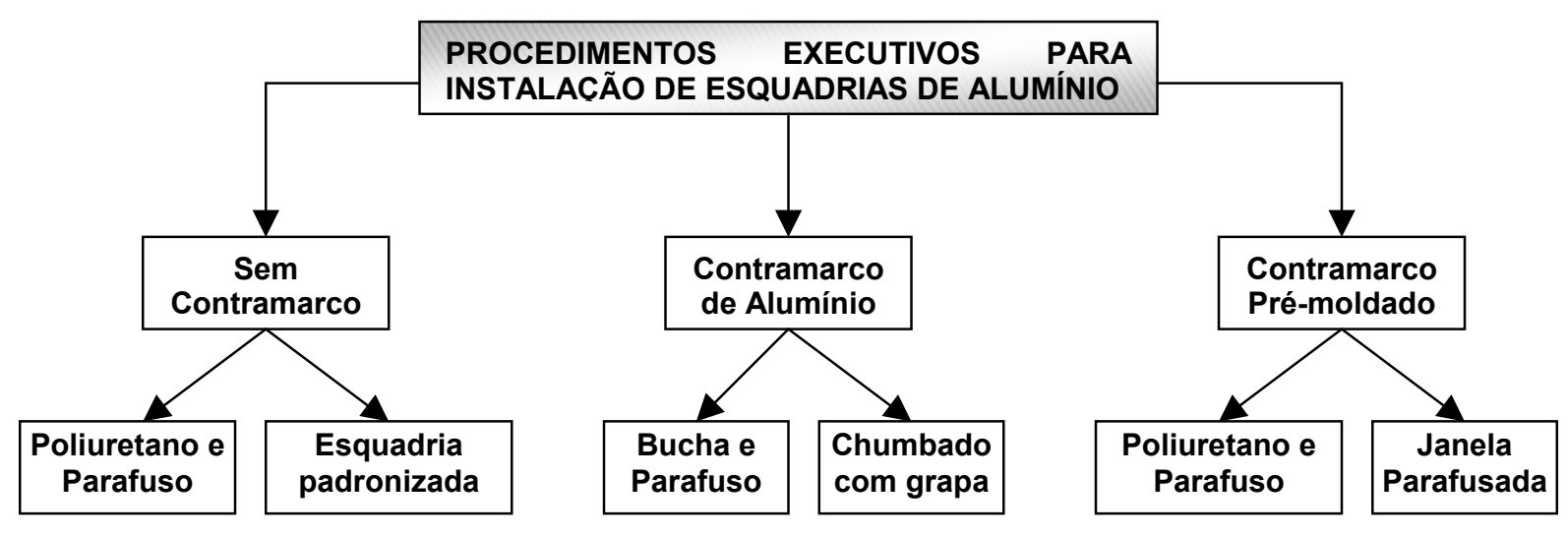

Figura 5.11: Resumo esquemático dos procedimentos executivos para instalação de esquadrias de alumínio

A escolha do procedimento executivo para a instalação das janelas de alumínio deve ser feita considerando-se as principais vantagens e desvantagens, listadas na tabela 5.3. 
Tabela 5.3: Quadro comparativo de vantagens e desvantagens dos procedimentos executivos das janelas.

\begin{tabular}{|c|c|c|}
\hline \multirow{8}{*}{ 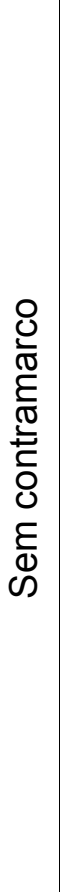 } & \multirow{4}{*}{ 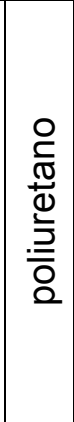 } & Vantagens \\
\hline & & $\begin{array}{l}\text { - Serviço de colocação da janela é realizado em uma só fase; } \\
\text { - Eliminação da etapa de assentamento do contramarco; } \\
\text {-Fixação das esquadrias em etapa posterior à execução dos } \\
\text { revestimentos. }\end{array}$ \\
\hline & & Desvantagens \\
\hline & & $\begin{array}{l}\text { - Necessidade de requadro dos vãos; } \\
\text { - Proteção contra os raios de sol; } \\
\text { - Treinamento da mão-de-obra para uso da espuma de poliuretano. }\end{array}$ \\
\hline & \multirow{4}{*}{ 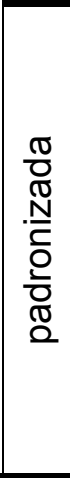 } & Vantagens \\
\hline & & $\begin{array}{l}\text { - Colocação da janela em uma só fase; } \\
\text { - Eliminação da etapa de assentamento do contramarco; } \\
\text { - Industrialização e padronização das esquadrias. }\end{array}$ \\
\hline & & Desvantagens \\
\hline & & $\begin{array}{l}\text { - Verificação da qualidade do perfil da esquadria possível após os } \\
\text { acabamentos finais, com a retirada do eucatex, dificultando eventuais } \\
\text { reparos; } \\
\text { - Possibilidade de prejuízo da iluminação natural, dependendo do tipo de } \\
\text { janela. }\end{array}$ \\
\hline \multirow{4}{*}{\multicolumn{2}{|c|}{ 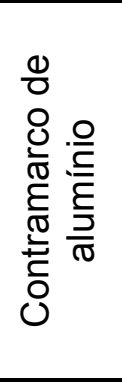 }} & Vantagens \\
\hline & & $\begin{array}{l}\text { - Fixação em etapa posterior à execução dos revestimentos; } \\
\text { - Facilidade de manuseio. }\end{array}$ \\
\hline & & Desvantagens \\
\hline & & $\begin{array}{l}\text { - Possibilidade de danos no perfil metálico do contramarco; } \\
\text { - Instalação da esquadria em duas etapas distintas; } \\
\text { - Preenchimento de vazios com argamassa; } \\
\text { - Necessidade de requadramento dos vãos da janela. }\end{array}$ \\
\hline \multirow{4}{*}{\multicolumn{2}{|c|}{ 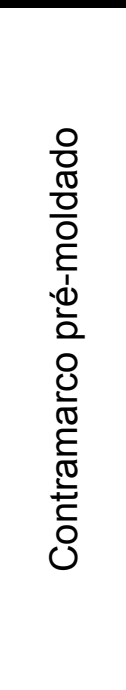 }} & Vantagens \\
\hline & & $\begin{array}{l}\text { - Fixação junto com a elevação da alvenaria. Terminalidade do serviço; } \\
\text { - Eliminação do preenchimento posterior de ajustes; } \\
\text { - Eliminação dos requadros junto aos vãos das janelas; } \\
\text { - Facilidade de execução de revestimentos, constituindo-se referências; } \\
\text { - Referência para assentamento de fiadas de blocos posteriores à sua } \\
\text { fixação; } \\
\text { - Apoio para assentamento de blocos canaleta, constituintes das vergas; } \\
\text { - Fixação das janelas em etapa posterior à execução dos revestimentos. }\end{array}$ \\
\hline & & Desvantagens \\
\hline & & $\begin{array}{l}\text { - Necessidade de instalação de unidades produtivas para fabricá-los; } \\
\text { - Uso de formas metálicas para moldagem das peças; } \\
\text { - Controle rigoroso da produção; } \\
\text { - Detalhamento do projeto e planejamento antecipado e criterioso do } \\
\text { empreendimento. }\end{array}$ \\
\hline
\end{tabular}




\subsubsection{Caixilhos Pré-moldados}

O sistema de caixilho pré-moldado é adquirido da fábrica pronto para ser instalado na obra. É constituído por um módulo vazado de concreto, onde está fixada a esquadria metálica ou de madeira ou diretamente o vidro, como está esquematizado na figura 5.12. Ele soluciona o problema de contramarco, esquadria, parapeito, vidro e bloqueador solar.

Os tipos de janelas que podem ser adquiridos com o sistema de caixilho pré-moldado são: maxim-ar, pivotante, fixa, fixa quadriculada e basculante.

O fabricante oferece uma linha de produtos complementares para serem utilizados em conjunto com o sistema, como: tela mosquiteira, grade inibitória e peças de acabamento.
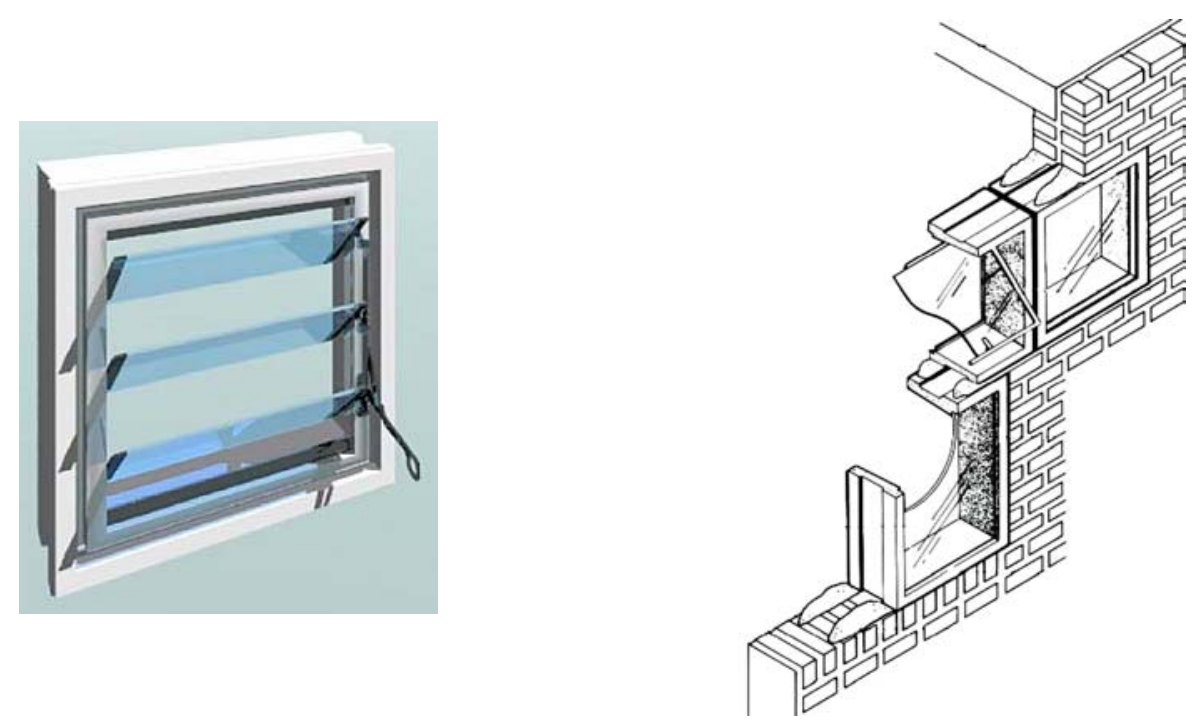

Figura 5.12: Esquema de caixilho pré-moldado acabado (WINBLOCK, 1999)

A grande vantagem deste sistema está em fixá-lo conjuntamente com a elevação da alvenaria, fazendo uso da técnica de assentamento de blocos e não necessitando de mão-de-obra especializada.

Outro fator relevante está em adquirir um produto de qualidade garantida, por ter sido executado em uma indústria especializada.

A desvantagem é encontrar dimensões modulares de, no máximo, $80 \mathrm{~cm}$, como conseqüência da limitação de peso. 
As dimensões limitadas trazem restrições ao uso, principalmente com relação à função de ventilação e iluminação, essenciais em alguns cômodos, como os dormitórios.

Segundo indicações do fabricante, o sistema suporta carregamento, dispensando-se uso da verga, de até $40 \mathrm{kN} / \mathrm{m}$.

O elemento pré-moldado não é armado; é constituído por matriz de concreto reforçada com fibras de nylon, que reduzem a fissuração e aumentam a resistência ao impacto. A resistência à compressão aos 28 dias do concreto, especificada pelo fabricante, é de $30 \mathrm{MPa}$.

Forças concentradas não devem estar aplicadas diretamente sobre o quadro do pré-moldado; no caso de serem inevitáveis, fazer reforço estrutural com inserção de armadura na região de vazio entre os módulos, ou prever a execução de uma verga que distribua as ações presentes.

Apesar do reforço das fibras, é inevitável que cantos e bordas lasquem durante o transporte, manuseio ou assentamento; portanto, antes da pintura, deve-se fazer o reparo, retoque ou fechamento de eventuais orifícios causados por bolhas de ar. Recomenda-se pintar o módulo após a fixação dos acessórios.

O fabricante especifica o silicone estrutural (silicone adesivo de cura neutra não acético) para a fixação do vidro ou da esquadria no pré-moldado de concreto, o que garante total vedação contra intempéries.

A composição dos módulos regula a passagem da luz solar e proporciona um efeito arquitetônico, como ilustrado na figura 5.13.
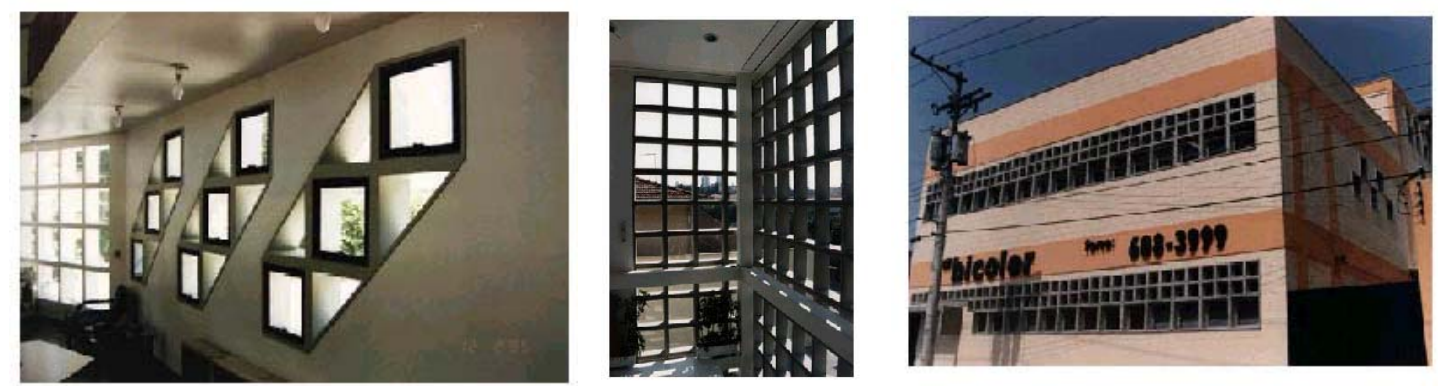

Figura 5.13: Efeito arquitetônico obtido com uso do caixilho pré-moldado (WINBLOCK, 1999) 


\subsection{Simulação do Comportamento das Aberturas nas Alvenarias Estruturais}

Com o objetivo de estudar o fluxo de tensões ao redor das aberturas, procurou-se fazer, neste trabalho, uma simulação teórica do comportamento das aberturas de portas e janelas em painéis isolados de alvenaria com função estrutural. A importância desta etapa do estudo está em determinar por quanto devem estender-se as vergas e contravergas (um bloco, dois blocos, etc) na parede adjacente à abertura.

Atualmente, utilizam-se indicações empíricas do comprimento de vergas e contravergas, como descrito por VILATÓ (1998), em que o apoio mínimo para vergas é de $20 \mathrm{~cm}$ e $30 \mathrm{~cm}$ para contravergas.

A simulação teórica será feita por modelagem numérica com elementos finitos, realizada no ANSYS ${ }^{\circledR 2}$, programa disponível no laboratório computacional do Departamento de Engenharia de Estruturas da Escola de Engenharia de São Carlos, e que vem apresentando resultados satisfatórios em pesquisas com a alvenaria estrutural com comportamento elástico-linear.

\subsubsection{Coleta de Dados da Freqüência das Aberturas em Edifícios Habitacionais}

O levantamento de dados teve por objetivo obter os valores usuais de aberturas referentes a portas e janelas de edifícios habitacionais em alvenaria estrutural, para que sirvam como parâmetros dimensionais na simulação teórica e no dimensionamento de vergas pré-moldadas.

Foram estudados trinta e oito (38) projetos realizados por um escritório de cálculo estrutural localizado na cidade de São Carlos.

Todos os projetos pesquisados apresentavam paredes estruturais com espessura de $14 \mathrm{~cm}$. Dezessete (17) deles eram modulados com blocos BL-20,

\footnotetext{
${ }^{2}$ ANSYS $^{\circledR}$ Analysis System - Release 5.4 (1997).
} 
enquanto os vinte e um (21) restantes possuíam modulação múltipla de $15 \mathrm{~cm}$ (BL-15).

A análise do levantamento foi feita para duas situações. Na primeira, foi considerada a quantidade total de aberturas iguais por pavimento. Já na segunda análise, foi considerada a quantidade de aberturas iguais por apartamento tipo e por dependência. Esta segunda análise foi feita para retirar a influência da repetição do apartamento tipo por pavimento e a repetição de cômodos por apartamento.

Tabela 5.4: Análise do levantamento dos valores usuais de aberturas de portas e janelas de edifícios de alvenaria estrutural com alvenaria modular BL-15.

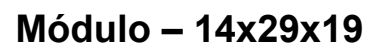

472 portas analisadas

\begin{tabular}{|c|c|c|c|}
\hline \multirow{6}{*}{$\begin{array}{l}\stackrel{9}{\mathbb{E}} \\
\stackrel{0}{0} \\
0\end{array}$} & \multicolumn{3}{|c|}{ Situação 1} \\
\hline & Vão & Quantidade & $\%$ \\
\hline & 90 & 262 & 55,3 \\
\hline & 75 & 96 & 20,3 \\
\hline & 150 & 28 & 5,9 \\
\hline & Total & 386 & 81,8 \\
\hline
\end{tabular}

102 portas analisadas

\begin{tabular}{|c|c|c|}
\hline \multicolumn{3}{|c|}{ Situação 2 } \\
\hline Vão & Quantidade & $\%$ \\
\hline 90 & 55 & 53,9 \\
\hline 75 & 17 & 16,7 \\
\hline 150 & 5 & 4,9 \\
\hline Total & 77 & 75,5 \\
\hline
\end{tabular}

396 janelas analisadas

\begin{tabular}{|c|c|c|c|}
\hline \multirow{6}{*}{ 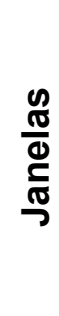 } & \multicolumn{3}{|c|}{ Situação 1} \\
\hline & $\begin{array}{c}\text { Larg } \times \text { Alt } \\
\text { Peitoril }\end{array}$ & Quantidade & $\%$ \\
\hline & $120 \times 120100$ & 136 & 34,3 \\
\hline & $150 \times 120100$ & 30 & 7,6 \\
\hline & $60 \times 60100$ & 29 & 7,3 \\
\hline & Total & 195 & 49,2 \\
\hline
\end{tabular}

91 janelas analisadas

\begin{tabular}{|c|c|c|}
\hline \multicolumn{3}{|c|}{ Situação 2 } \\
\hline $\begin{array}{c}\text { Larg } \times \text { Alt } \\
\text { Peitoril }\end{array}$ & Quantidade & $\%$ \\
\hline $120 \times 120100$ & 21 & 19,1 \\
\hline $60 \times 60160$ & 8 & 7,3 \\
\hline $140 \times 120100$ & 6 & 5,5 \\
\hline Total & 35 & 31,9 \\
\hline
\end{tabular}

*Obs: Estão tabeladas as dimensões de portas e janelas que apareceram com maior freqüência. As demais dimensões, omitidas, completam os $100 \%$ do total. 
Tabela 5.5: Análise do levantamento dos valores usuais de aberturas de portas e janelas de edifícios de alvenaria estrutural com alvenaria modular BL-20.

Módulo - 14×39x19

436 portas analisadas

\begin{tabular}{|c|c|c|c|}
\hline \multirow{6}{*}{ 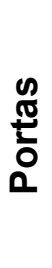 } & \multicolumn{3}{|c|}{ Situação 1} \\
\hline & Vão & Quantidade & $\%$ \\
\hline & 80 & 192 & 41,7 \\
\hline & 85 & 72 & 15,5 \\
\hline & 90 & 26 & 7,8 \\
\hline & Total & 301 & 65 \\
\hline
\end{tabular}

379 janelas analisadas

\begin{tabular}{|c|c|c|c|}
\hline \multirow{6}{*}{ 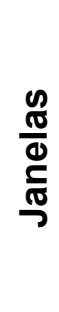 } & \multicolumn{3}{|c|}{ Situação 1} \\
\hline & $\begin{array}{c}\text { Larg } \times \text { Alt } \\
\text { Peitoril }\end{array}$ & Quantidade & $\%$ \\
\hline & $120 \times 120100$ & 127 & 33,5 \\
\hline & $60 \times 60100$ & 56 & 14,8 \\
\hline & $140 \times 120100$ & 48 & 12,7 \\
\hline & Total & 231 & 61 \\
\hline
\end{tabular}

88 portas analisadas

\begin{tabular}{|c|c|c|}
\hline \multicolumn{3}{|c|}{ Situação 2 } \\
\hline Vão & Quantidade & $\%$ \\
\hline 80 & 27 & 30,7 \\
\hline 100 & 11 & 12,5 \\
\hline 85 e 90 & 9 & 10,2 \\
\hline Total & 47 & 53,4 \\
\hline
\end{tabular}

61 janelas analisadas

\begin{tabular}{|c|c|c|}
\hline \multicolumn{3}{|c|}{ Situação 2 } \\
\hline $\begin{array}{c}\text { Larg } \times \text { Alt } \\
\text { Peitoril }\end{array}$ & Quantidade & $\%$ \\
\hline $120 \times 120100$ & 14 & 23 \\
\hline $60 \times 60160$ & 10 & 16,4 \\
\hline $140 \times 120100$ & 5 & 8,2 \\
\hline Total & 29 & 47,6 \\
\hline
\end{tabular}

*Obs: Estão tabeladas as dimensões de portas e janelas que apareceram com maior freqüência. As demais dimensões, omitidas, completam os $100 \%$ do total.

Para todas as aberturas referentes às portas, a altura encontrada foi de $221 \mathrm{~cm}$

Percebe-se, ao observar as tabelas 5.4 e 5.5, baixa freqüência de repetição das aberturas de janelas, porque as janelas podem diferenciar-se tanto na largura, quanto na altura e no peitoril, enquanto que as portas somente apresentaram variação no vão horizontal da abertura.

\subsubsection{Metodologia Empregada para a Entrada de Dados}

As informações preliminares fornecidas pelo usuário ao programa computacional são de extrema importância para a representação fiel do comportamento da estrutura.

Adotaram-se propriedades dos materiais, dimensões de panos de alvenaria, carregamentos e características de elementos para a modelagem que representassem com eficiência e simplicidade o fluxo de tensões nas alvenarias estruturais. 
O material constituinte da alvenaria foi considerado isotrópico, composto por bloco de concreto em associação à argamassa de assentamento; porém, não houve divisão, na discretização, entre o bloco e a argamassa, considerando-se o conjunto como um todo, com propriedades:

Resistência característica de blocos de concreto Módulo de deformação longitudinal da alvenaria Coeficiente de Poisson

$$
\begin{gathered}
\mathrm{f}_{\mathrm{bk}}=4,5 \mathrm{MPa} \\
\mathrm{E}_{\mathrm{PA}}=800 \times \mathrm{f}_{\mathrm{bk}}=3600 \mathrm{MPa} \\
0,20
\end{gathered}
$$

O valor adotado para o módulo de deformação longitudinal da alvenaria $\left(E_{P A}\right)$ é padrão e foi baseado nos ensaios realizados por JUSTE $(2001)^{3}$ nos laboratórios da Escola de Engenharia de São Carlos.

A resistência característica do bloco $\left(f_{b k}\right)$ de $4,5 \mathrm{MPa}$ representa um valor usual para edifícios de alvenaria estrutural com quatro pavimentos, além de ser a resistência mínima estabelecida pela ABNT (1994), NBR-6136, para blocos de concreto para alvenaria estrutural.

Para efeito de simplificação, não foi considerada a não-linearidade física do material no processamento.

As dimensões utilizadas para a modelagem dos panos de alvenaria foram baseadas na coleta de dados de aberturas usuais de portas e janelas em edifícios habitacionais, em alvenaria estrutural, anteriormente apresentados nas tabelas 5.4 e 5.5 .

A classificação dos modelos é dada por uma letra que representa porta $(P)$ ou janela $(\mathrm{J})$, seguida por um número que equivale à dimensão do vão da

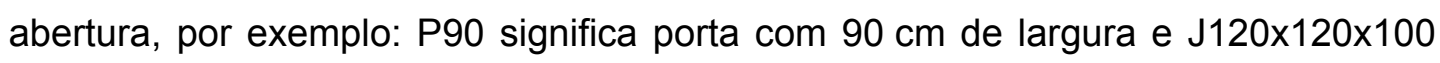
significa janela com $120 \mathrm{~cm}$ de largura, $120 \mathrm{~cm}$ de altura e $100 \mathrm{~cm}$ de peitoril.

As paredes têm espessura de $14 \mathrm{~cm}$ e altura de pé direito de $272 \mathrm{~cm}$, valor este também extraído da coleta de dados. Cabe notar que a variação do pé-direito de $240 \mathrm{~cm}$ a $280 \mathrm{~cm}$ não tem influência significativa na análise aqui realizada. Adjacentes às aberturas, são encontradas paredes com $120 \mathrm{~cm}$ para

\footnotetext{
3 JUSTE, A.E. (2000). (USP. Escola de Engenharia de São Carlos. Departamento de Engenharia de Estruturas)./ Trabalho em andamento /
} 
cada lado, largura suficiente para que as tensões concentradas nos cantos das aberturas se estabilizem.

Para a simulação do carregamento, considerou-se um edifício de quatro pavimentos, cuja parede inferior (analisada) é solicitada pelo peso das paredes dos pavimentos superiores e pela contribuição das reações das lajes; o seu peso próprio foi desconsiderado.

A contribuição do carregamento do pavimento foi calculada com base em lajes maciças de concreto de $8 \mathrm{~cm}$ de espessura, vãos típicos de $3 \mathrm{~m}$, armadas em uma única direção (situação crítica), o que resultou no valor da reação de $6 \mathrm{kN} / \mathrm{m}$.

As paredes externas receberam carregamento equivalente a $34 \mathrm{kN} / \mathrm{m}$ e as paredes internas $52 \mathrm{kN} / \mathrm{m}$.

O elemento utilizado para o processamento foi o Plane 42, quadrilateral, com quatro nós e dois graus de liberdade por nó, para estado plano de tensão.

A estrutura foi discretizada por elementos espaçados de $10 \mathrm{~cm}$. Todos os nós localizados na base da estrutura foram definidos como totalmente restritos.

\subsubsection{Resultados Obtidos}

Os resultados obtidos com a discretização das aberturas nas alvenarias são apresentados e discutidos apenas para os casos críticos: P100, J120×120×100 e JE120x120x100. A designação JE significa janela com elementos enrijecidos nas regiões de vergas e contravergas, ou seja, o valor do módulo de elasticidade destes elementos é dobrado para simular o grauteamento das vergas e contravergas.

O critério para análise dos resultados das tensões foi extraído da norma brasileira (ABNT,1989) e da norma britânica (BS, 1992) e está esquematizado na tabela 5.6. 
Tabela 5.6: Valores das tensões admissíveis na alvenaria não armada.

\begin{tabular}{|l|c|}
\hline Tipo de solicitação & Tensões admissíveis (MPa) \\
\hline Cisalhamento & 0,15 \\
\hline Compressão Concentrada & $2 \times \mathrm{f}_{\mathrm{Mk}}{ }^{*}$ \\
\hline
\end{tabular}

* Resistência à compressão média atuante na parede adjacente à abertura.

O valor admissível para a concentração de tensões nos cantos das aberturas foi adaptado da norma britânica, que especifica indicações sobre carregamento concentrado, as quais foram adaptadas para tensões concentradas, utilizadas neste trabalho.

O resultado do processamento da modelagem em elementos finitos está esquematizado em figuras que representam o fluxo de tensões (figuras 5.14 a 5.18) e as deformações (anexo B):

- $\quad$ tensões no plano vertical $\left(\sigma_{y}\right)$

- $\quad$ tensões no plano horizontal $\left(\sigma_{\mathrm{x}}\right)$;

- tensões de cisalhamento $\left(\tau_{x y}\right), \mathrm{e}$

- $\quad$ deformações no plano horizontal $\left(\varepsilon_{y}\right)$.

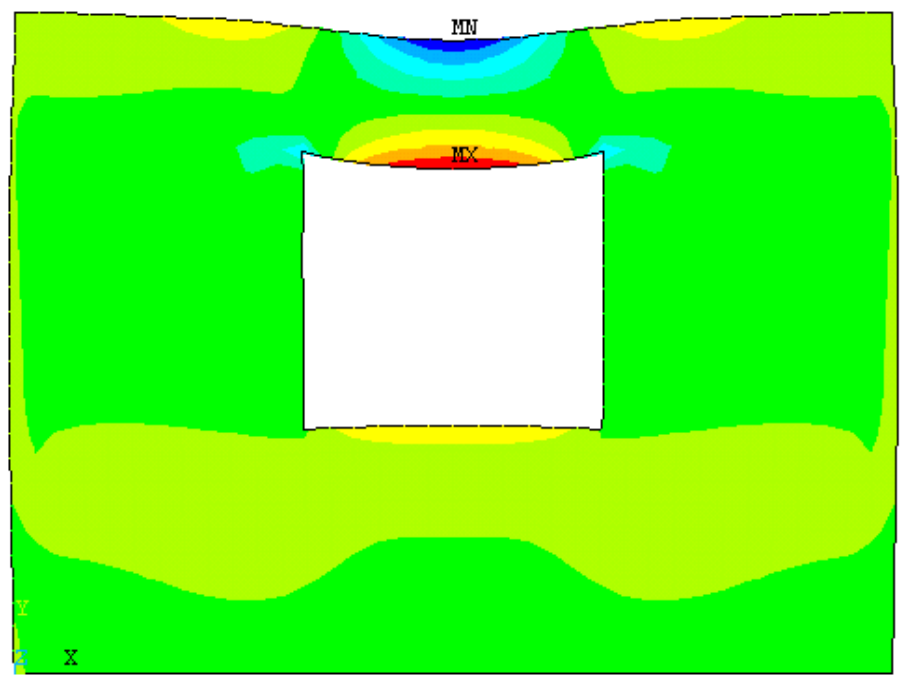

Figura 5.14: Tensões $\sigma_{x}$ para J120x120x100 $\left(\mathrm{kN} / \mathrm{cm}^{2}\right)$ 
Analisando-se a figura 5.14, conclui-se que é necessária a presença da verga e contraverga para evitar o surgimento de fissuras sobre/sob as aberturas de janelas, pois a alvenaria não suportaria as tensões de tração atuantes.
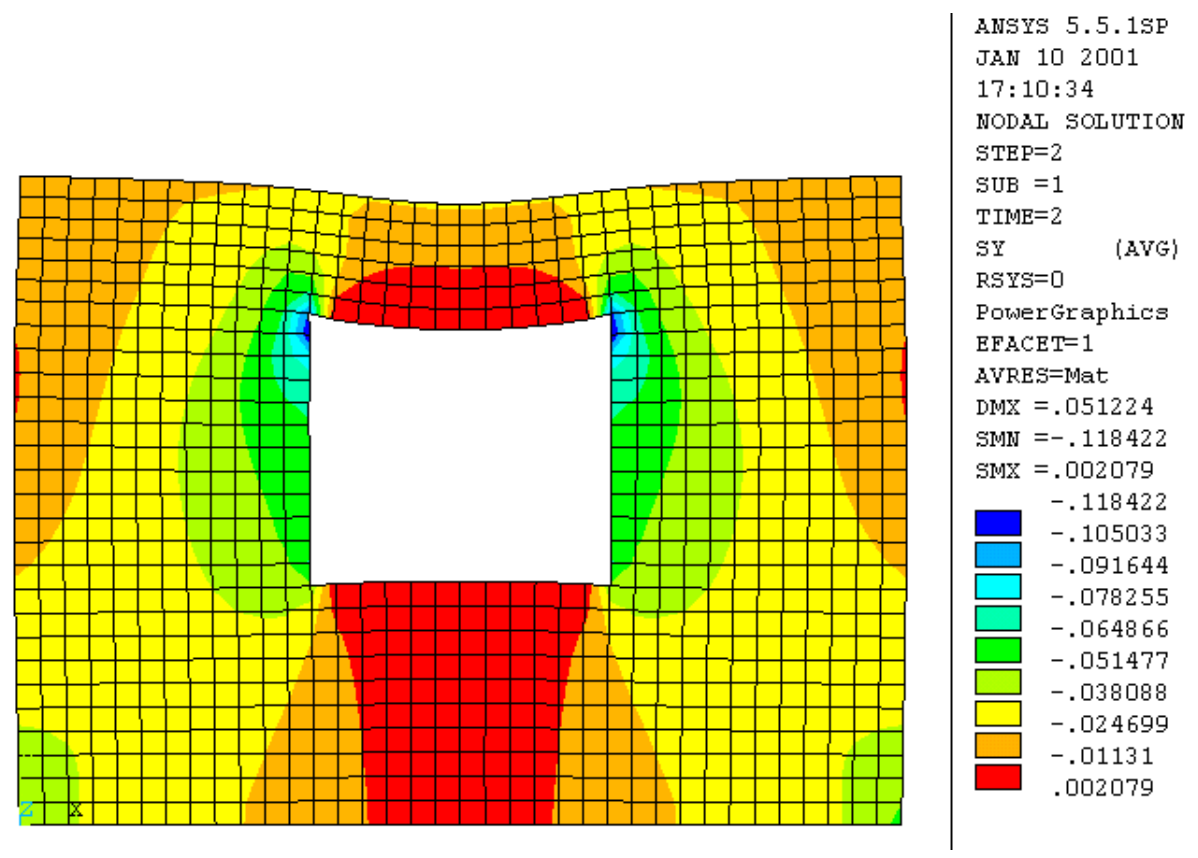

Figura 5.15: Tensões $\sigma_{y}$ para J120x120x100 $\left(\mathrm{kN} / \mathrm{cm}^{2}\right)$

A malha quadriculada tem espaçamento de $10 \mathrm{~cm}$. O valor da tensão média de compressão atuante nas paredes adjacentes é de: $0,036 \mathrm{kN} / \mathrm{cm}^{2}$.

Nos cantos superiores das aberturas, há uma concentração de tensões de compressão, como ilustrado na figura 5.15. O valor desta tensão concentrada ultrapassa o valor admissível, adotado como o dobro da tensão média de compressão atuante nas paredes adjacentes $\left(2 \mathrm{x}_{\mathrm{Mk}}\right)$.

Para absorver as tensões concentradas dos cantos, as vergas devem estender-se além do vão da abertura. Um bloco de cada lado dos vãos é uma medida razoável, pois aproveita-se a modulação da alvenaria, simplificando a execução. Na realidade, seria necessária distância inferior a um bloco.

Os cantos inferiores das aberturas não apresentam concentração de tensões, não necessitando, "a priori", que as contravergas se alonguem além do vão da abertura. No entanto, para esta modelagem não foi considerada a retração 
da parede; portanto, recomenda-se também estender a contraverga um bloco de cada lado do vão da abertura.

A prática de aproveitar a cinta à meia altura para exercer também a função de contraverga traz benefícios estruturais; portanto, é bem aceita e recomendada.

Pode-se comprovar, ao observar a figura 5.15, que o grauteamento vertical da parede na região adjacente à abertura tem fundamentos teóricos. $\mathrm{Na}$ prática, o graute é colocado ao longo do pé direito da parede; no entanto, ele apresenta funcionalidade, para o carregamento vertical, apenas na região entre a verga e a contraverga.
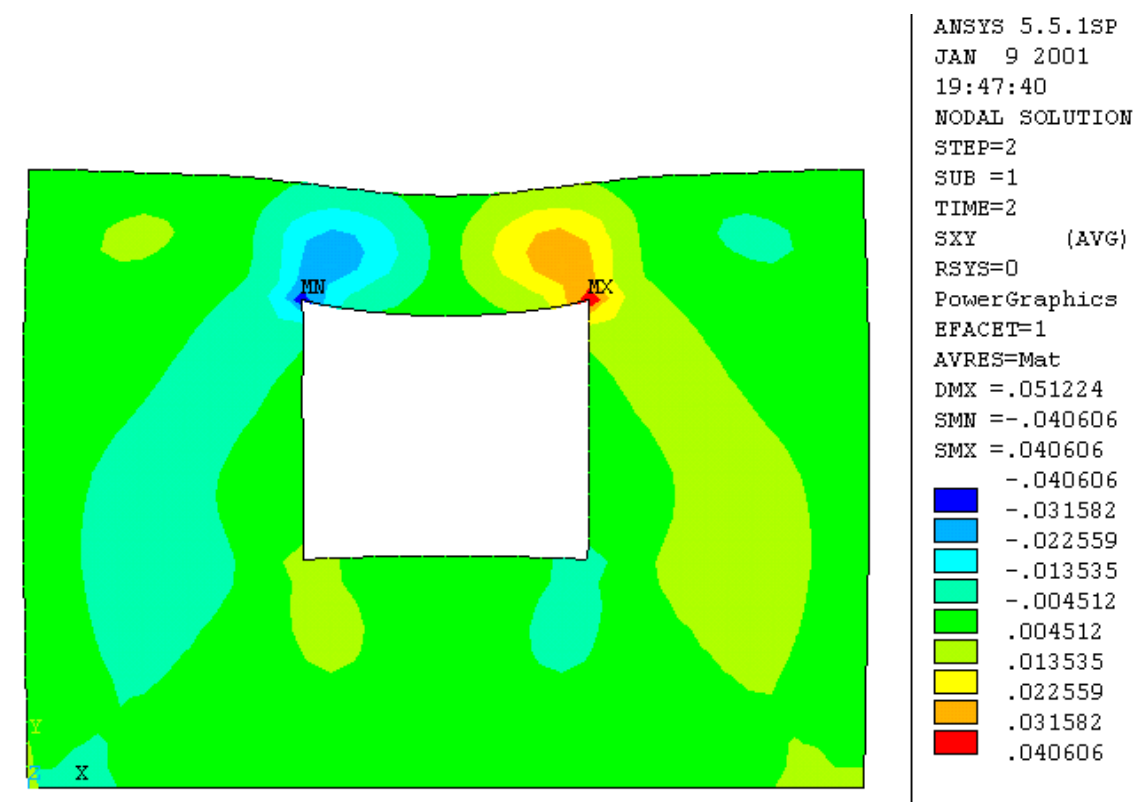

Figura 5.16: Tensões $\tau_{\mathrm{xy}}$ para J120x120x100 $\left(\mathrm{kN} / \mathrm{cm}^{2}\right)$

O valor da tensão de cisalhamento atuando nos cantos superiores das aberturas é superior ao valor admissível especificado pela ABNT (0,15 MPa), comprovando a necessidade de armadura nessa região.

Ao considerar a alvenaria armada, o limite admissível para tensões de cisalhamento, segundo a ABNT (1989), elevar-se-ia para 0,27MPa. Ainda assim, os valores de tensões atuantes concentrados nos cantos superiores ultrapassam os admissíveis. No entanto, não é abuso extrapolar o critério convencionado para o 
limite da concentração de tensões de compressão para as tensões de cisalhamento, o que dobraria o seu valor.

As figuras ilustrando os resultados obtidos pelos modelos de panos de alvenarias com simulação de vergas e contravergas por enrijecimento de elementos sobre e sob o vão da abertura encontram-se anexados a este trabalho (anexo B). A deformação para os modelos enrijecidos foi aproximadamente metade da deformação para os modelos sem enrijecimento, o que já era esperado, pois foi utilizada a modelagem elástica-linear $(\sigma=\mathrm{E} . \varepsilon)$. No entanto, houve pouca alteração no valor das tensões.

Análise semelhante à que foi feita para aberturas de janelas é feita para as portas e os resultados dos modelos de P100 são apresentados nas figuras 5.17 e 5.18 .
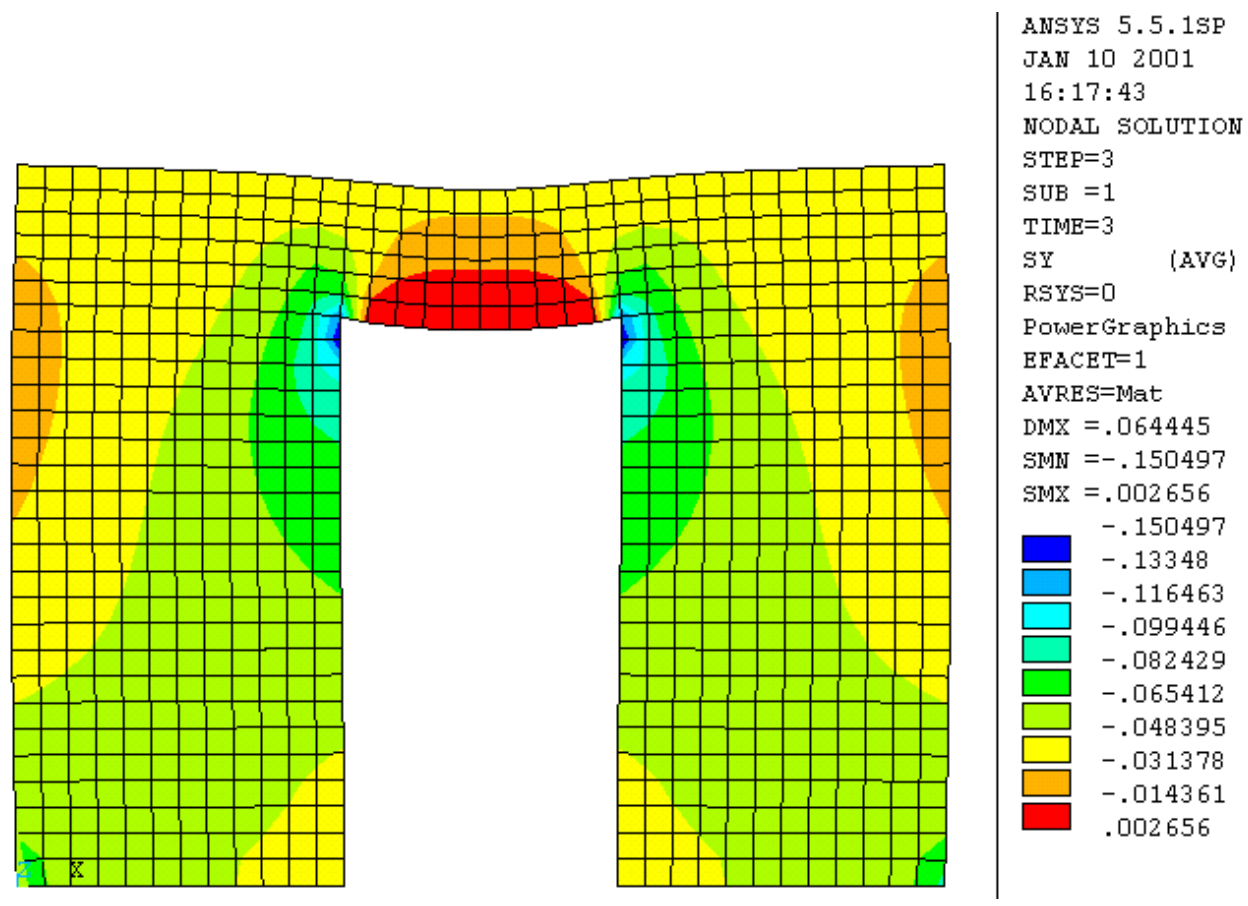

Figura 5.17: Tensões $\sigma_{y}$ para $\mathrm{P} 100\left(\mathrm{kN} / \mathrm{cm}^{2}\right)$

A malha quadriculada tem espaçamento de $10 \mathrm{~cm}$. O valor da tensão média de compressão atuante nas paredes adjacentes é de: $0,0526 \mathrm{kN} / \mathrm{cm}^{2}$ 


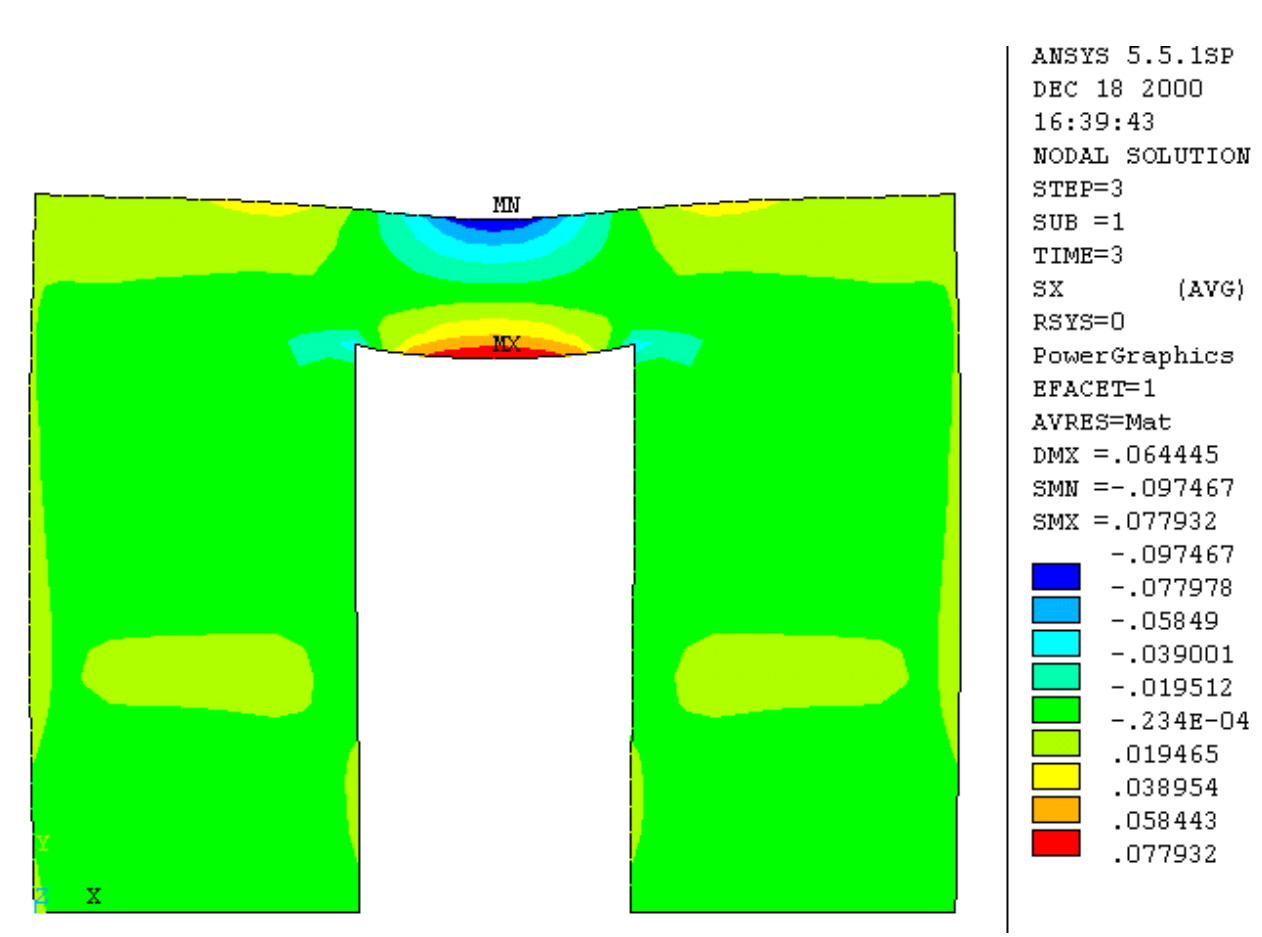

Figura 5.18: Tensões $\sigma_{x}$ para $\mathrm{P} 100\left(\mathrm{kN} / \mathrm{cm}^{2}\right)$

Assim como para as janelas, há a necessidade da presença da verga sobre o vão da porta e esta deve estender-se além do vão da abertura para absorver as tensões concentradas nos cantos.

A malha quadriculada do gráfico de fluxo de tensões na vertical $\left(\sigma_{y}\right)$ mostra que $10 \mathrm{~cm}$ além do vão da abertura são suficientes para dissipar as tensões concentradas. Quando a verga é executada por blocos canaleta, certamente o valor $10 \mathrm{~cm}$ é superado, pois geralmente a verga se estende por um bloco; no entanto, quando se faz uso de vergas pré-moldadas, a extensão mínima é fator importante, imposta por limitações no apoio das vergas, melhor compreendidas no próximo item. 


\subsection{Vergas e Contravergas}

As vergas e contravergas são elementos estruturais essenciais em uma edificação para se evitar o surgimento de patologias indesejáveis, como as fissuras em regiões próximas às aberturas.

Elas são localizadas sobre (verga) ou sob (contraverga) os vãos das aberturas nas edificações e promovem a distribuição das tensões concentradas nos cantos e a absorção de trações horizontais nessas aberturas.

Considerando-se a quantidade de aberturas referentes a portas e janelas que uma edificação residencial apresenta, pode-se dizer que as vergas e contravergas merecem ser estudadas e analisadas com bastante atenção.

\subsubsection{As Vergas em Edifícios de Alvenaria Estrutural}

A ABNT (1989), NBR 10837 define como verga o elemento estrutural colocado sobre vãos de aberturas não maiores que $1,20 \mathrm{~m}$, a fim de transmitir cargas verticais para as paredes adjacentes aos vãos.

Para o cálculo da verga adota-se como carregamento, o peso da parede compreendida no triângulo isósceles definido sobre o vão da abertura. A carga uniformemente distribuída de um pavimento acima do triângulo referido não é considerada, como esquematizado na figura 5.19. Da carga uniformemente distribuída do pavimento que atue dentro do triângulo isósceles, só é considerada a parte compreendida dentro do triângulo.
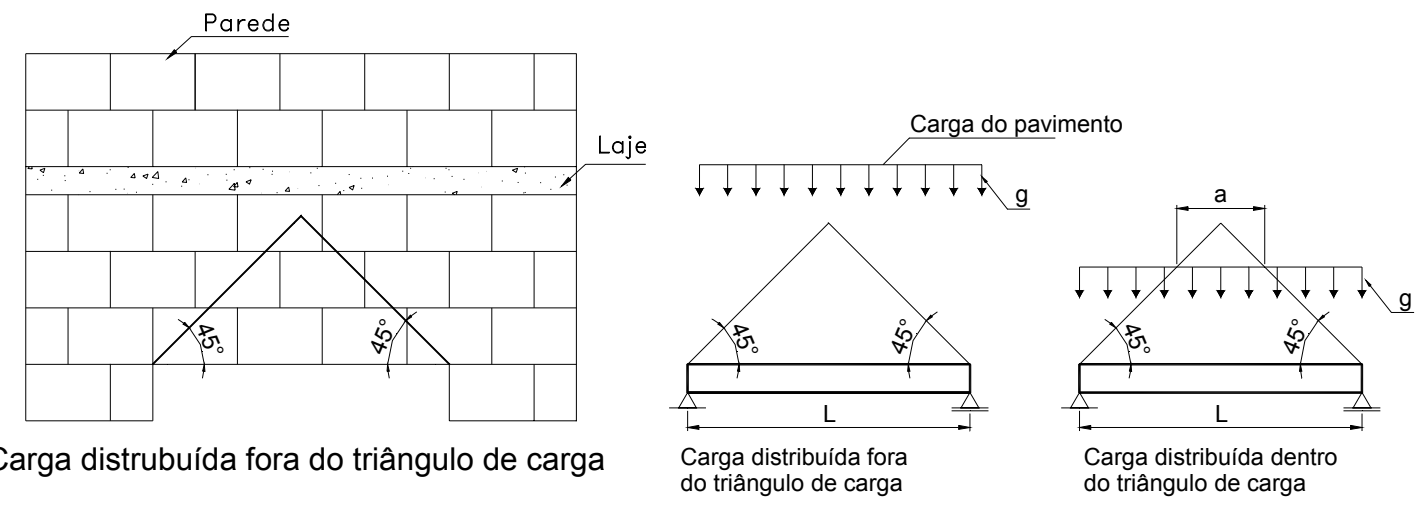

Figura 5.19: Esquema de distribuição do carregamento vertical para o dimensionamento de vergas segundo especificações da ABNT (1989) 
Para cargas concentradas aplicadas no interior ou na proximidade do triângulo de carga, é adotada uma distribuição a $60^{\circ}$. Se a carga concentrada ficar fora do triângulo de carga, só deve ser considerada a uniformemente distribuída (g) dentro do vão da verga, conforme ilustrado na figura 5.20; à carga uniformemente distribuída há que se acrescentar o peso da alvenaria, situada no interior do triângulo sobre a verga.

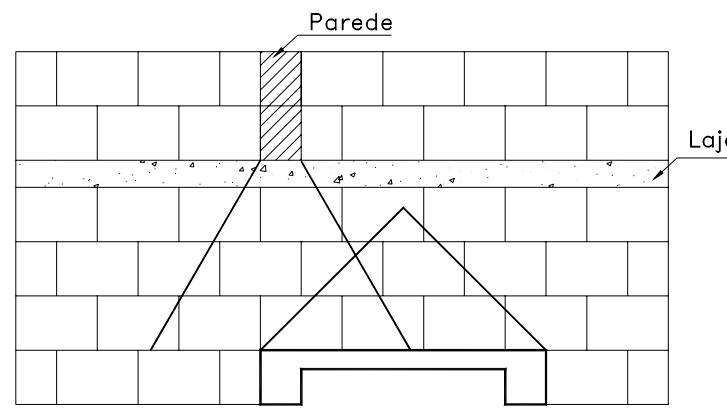

Carga concentrada fora do triângulo de carga

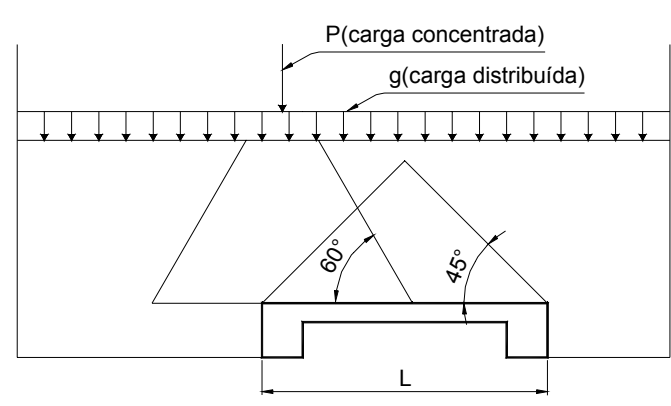

Figura 5.20: Esquema de distribuição de cargas concentradas verticais para o dimensionamento de vergas segundo especificações da ABNT (1989)

Ao analisar o esquema de distribuição de cargas verticais para o dimensionamento de vergas, pode-se afirmar que o carregamento dependerá do vão da abertura, da reação da laje e de eventuais interferências de cargas concentradas.

O modo usual de execução de vergas em edifícios de alvenaria estrutural é por assentamento de blocos canaleta sobre um gabarito metálico ou de madeira que servirá de apoio, distribuição da armadura e posterior grauteamento.

A solução de execução das vergas a partir de blocos canaleta, no entanto, exige que o operário interrompa a elevação da parede para o posicionamento do gabarito de apoio, colocação da armadura, seguido de grauteamento, quebrando o ritmo de produção.

HEINECK (1991) afirma que "cada interrupção causa um desaprendizado, um retorno a um patamar de produtividade inferior" e complementa ao dizer que há necessidade de deslocamento de operários sem interrupção de uma tarefa para outra ou dentro da própria tarefa, não podendo haver parada devido à falta de materiais, detalhamento construtivo ou interferências 
com outras tarefas. A conclusão a que este autor chega é de um aumento de produtividade da mão-de-obra em torno de $50 \%$ na execução da alvenaria sobre o efeito de continuidade do trabalho.

Em comparação ao procedimento tradicional de execução de vergas por blocos canaleta, as vergas pré-moldadas não interrompem o ritmo da produção. Além do ganho da produtividade na execução da alvenaria, as vergas pré-moldadas permitem que haja um ajuste dimensional existente entre a altura da esquadria e abertura na alvenaria, como esquematizado na figura 5.21 .

Considerando-se que a modulação altimétrica da alvenaria estrutural é realizada com módulo de 20, percebe-se pelos dados apresentados na tabela 5.1, sobre alturas de portas padronizadas encontradas no mercado brasileiro, que, para a maioria dos modelos, há um ajuste na altura entre a abertura na parede e a esquadria. Este ajuste é calculado na mesma tabela e pode ser visualizado na figura 5.21 .
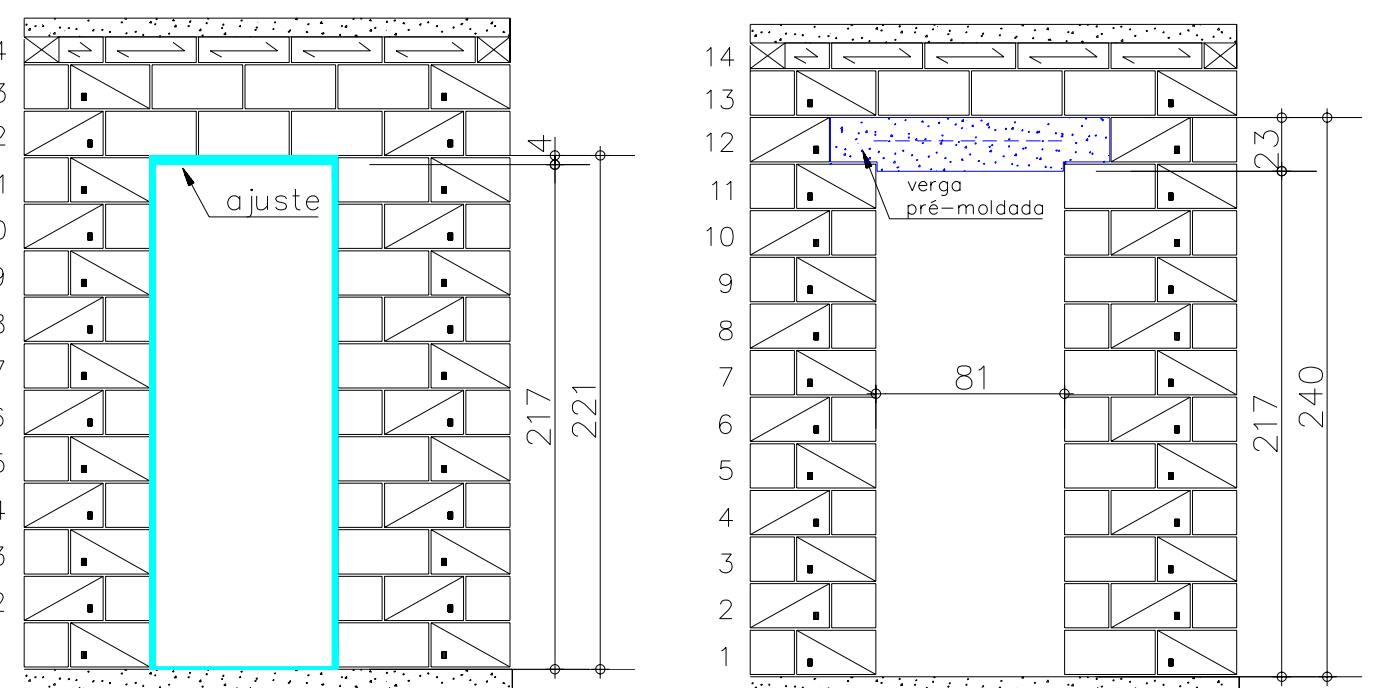

Figura 5.21: Visualização do ajuste dimensional, proporcionado pela verga prémoldada, para portas com batentes de madeira

As vergas pré-moldadas em concreto armado podem ser executadas pela construtora no próprio canteiro de obra, com as dimensões e armaduras necessárias para cada vão de abertura e são simplesmente assentadas na alvenaria assim como os blocos. 
O peso é um fator limitante para a concepção da geometria das vergas pré-moldadas, pois elas deverão ser compatíveis com a capacidade portante dos operários. A recomendação da Organização Internacional do Trabalho é de, no máximo, $50 \mathrm{~kg}$ por operário (GRANDJEAN, 1991).

A limitação do peso faz com que a seção transversal das vergas pré-moldadas tenha forma de "U", conforme ilustrado nas figuras 5.22 e 5.23.

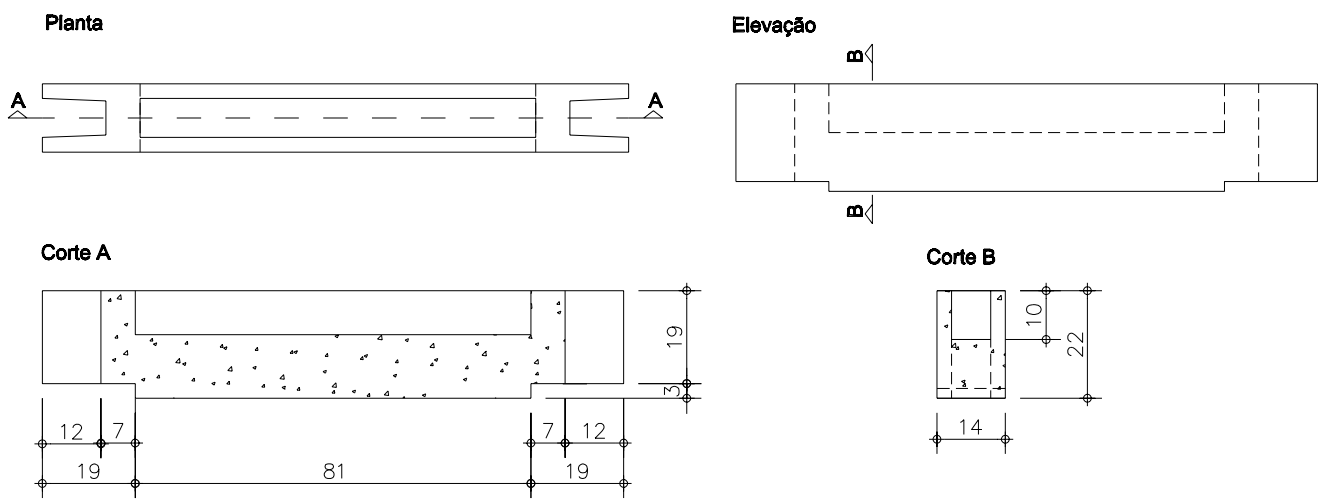

Figura 5.22: Verga pré-moldada sobre portas padronizadas com folhas e batentes de madeira, para ajuste de $3 \mathrm{~cm}$ na altura

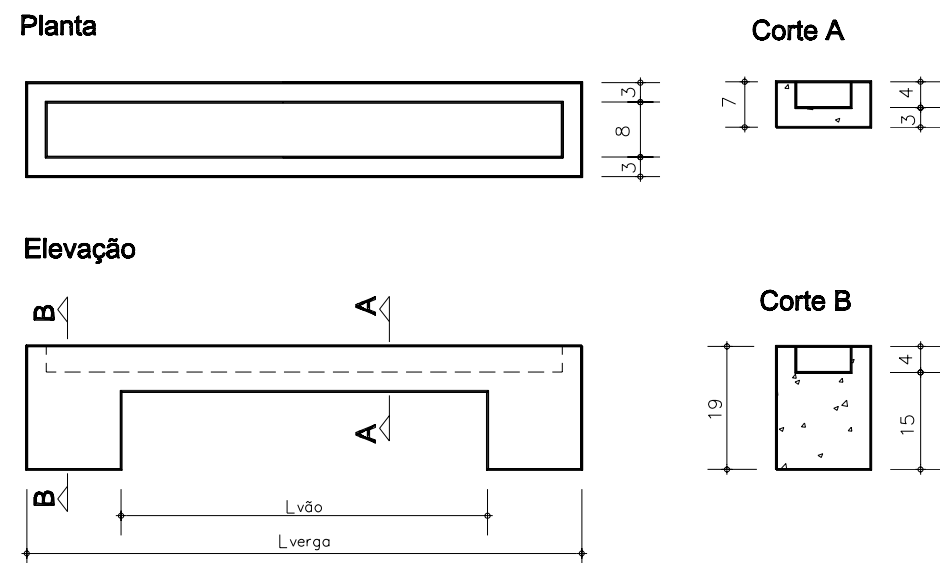

Figura 5.23: Geometria e dimensões de uma verga pré-moldada sobre portas com folha de madeira e batente metálico envolvente para ajuste de $7 \mathrm{~cm}$ na altura

Os pesos das vergas pré-moldadas ilustradas nas figuras 5.22 e 5.23 foram calculados para diversos vãos de aberturas e são apresentados na tabela 5.7. O cálculo foi feito para concreto armado, cujo peso equivale a $25 \mathrm{kN} / \mathrm{m}^{3}$. 
Tabela 5.7: Pesos de vergas pré-moldadas em função do comprimento do vão da abertura.

\begin{tabular}{|c|c|}
\hline \multicolumn{2}{|c|}{$\begin{array}{c}\text { Verga p/ajuste de } \\
3 \mathrm{~cm} \text { (fig. } 5.22 \text { ) }\end{array}$} \\
\hline Vão (cm) & Peso (kg) \\
\hline 1) 60 & 51,0 \\
\hline 2) 70 & 57,0 \\
\hline 3) 80 & 62,5 \\
\hline 4) 90 & 68,0 \\
\hline 5) 100 & 74,0 \\
\hline 6) 120 & 85,0 \\
\hline
\end{tabular}

\begin{tabular}{lc}
\hline \multicolumn{2}{c}{$\begin{array}{c}\text { Verga p/ ajuste de } \\
\mathbf{7} \mathbf{~ c m ~ ( f i g . ~ 5 . 2 3 ) ~}\end{array}$} \\
\hline \multicolumn{1}{c}{ Vão (cm) } & Peso (kg) \\
\hline 1) 60 & 31,0 \\
2) 70 & 32,5 \\
3) 80 & 34,0 \\
4) 90 & 36,0 \\
5) 100 & 37,5 \\
6) 120 & 41,0 \\
\hline
\end{tabular}

Como pode ser constatado na tabela 5.7 , todas as vergas pré-moldadas com geometria equivalente à apresentada na figura 5.23 são apropriadas ao manuseio de um operário e para as vergas com geometria da figura 5.22, apropriadas ao manuseio de 2 operários (limite de $100 \mathrm{~kg}$ ). O peso dos elementos pré-moldados pode ainda ser reduzido com uso de concretos especiais ou adições.

Tendo como referência o levantamento dos dados das medidas usuais de aberturas, apresentado no item 5.2.1, as vergas pré-moldadas foram dimensionadas para diferentes vãos. O carregamento, os esforços, os valores das armaduras longitudinal e transversal e a verificação da tensão de cisalhamento e de contato estão apresentados na tabela 5.8.

O carregamento ao qual a verga está submetida engloba o peso da parede situada dentro do triângulo isósceles sobre a verga, como especificado pela ABNT (1989), NBR 10837. Não houve contribuição da reação da laje do pavimento, pois o triângulo isósceles definido sobre as aberturas não atingiu o nível do pé-direito.

\begin{tabular}{|l|}
\hline MODELO DE DIMENSIONAMENTO \\
\hline Carregamento \\
Reação da laje $(\mathrm{h}=8 \mathrm{~cm}): 12 \mathrm{kN} / \mathrm{m}$. \\
Peso da parede: $\left[0,14 \times \mathrm{L}_{\text {vão }} / 4 \times 24\right] / \mathrm{L}_{\text {vão }}=0,84 \times \mathrm{L}_{\text {vão }}[\mathrm{kN} / \mathrm{m}]$ \\
Peso próprio: $25 \times 0,0066=0,165 \mathrm{Kn} / \mathrm{m}$ \\
\hline Cálculo da posição da $\mathrm{LN}$ \\
$\mathrm{x}=4 \mathrm{~cm}$
\end{tabular}


Tabela 5.8: Cálculo da armadura longitudinal e transversal das vergas pré-moldadas em função do vão da abertura e verificação da tensão de cisalhamento e da tensão de contato na alvenaria.

\begin{tabular}{|c|c|c|c|c|c|c|c|c|c|}
\hline $\begin{array}{l}\text { Vão } \\
\mathrm{cm}\end{array}$ & $\begin{array}{c}\text { Carrega } \\
\text { mento } \\
\mathrm{kN} / \mathrm{m}\end{array}$ & $\begin{array}{c}\mathbf{M}_{\mathbf{k}} \\
\mathrm{kN} \cdot \mathrm{m}\end{array}$ & $\begin{array}{l}\mathbf{R} \\
\mathrm{kN} \\
\end{array}$ & $\begin{array}{c}A_{\mathbf{s}} \\
\mathrm{cm}^{2}\end{array}$ & $\phi$ & $\begin{array}{l}\mathbf{V}_{\mathbf{d}} \\
\mathrm{kN}\end{array}$ & $\mathbf{V}_{\mathrm{d}}<\mathbf{v}_{\mathrm{k}}$ & $\begin{array}{l}A_{S_{w}} / \phi \\
\mathrm{cm}^{2} / \mathrm{m}\end{array}$ & $\begin{array}{l}f_{\text {con }} \\
M P a\end{array}$ \\
\hline 60 & 0,67 & 0,054 & 0,27 & 0,15 & $2 \phi 5$ & 0,28 & OK & $\phi 5 \mathrm{c} / 20$ & 0,010 \\
\hline 65 & 0,71 & 0,064 & 0,30 & 0,15 & $2 \phi 5$ & 0,32 & OK & $\phi 5 \mathrm{c} / 20$ & 0,011 \\
\hline 75 & 0,80 & 0,09 & 0,38 & 0,15 & $2 \phi 5$ & 0,42 & OK & $\phi 5 \mathrm{c} / 20$ & 0,014 \\
\hline 80 & 0,84 & 0,105 & 0,42 & 0,15 & $2 \phi 5$ & 0,47 & $\mathrm{OK}$ & $\phi 5 \mathrm{c} / 20$ & 0,015 \\
\hline 85 & 0,88 & 0,12 & 0,46 & 0,15 & $2 \phi 5$ & 0,52 & OK & $\phi 5 \mathrm{c} / 20$ & 0,016 \\
\hline 90 & 0,92 & 0,14 & 0,51 & 0,15 & $2 \phi 5$ & 0,59 & $\mathrm{OK}$ & $\phi 5 \mathrm{c} / 20$ & 0,018 \\
\hline 100 & 1,01 & 0,18 & 0,61 & 0,15 & $2 \phi 5$ & 0,71 & OK & $\phi 5 \mathrm{c} / 20$ & 0,022 \\
\hline 105 & 1,10 & 0,21 & 0,69 & 0,15 & $2 \phi 5$ & 0,82 & OK & $\phi 5 \mathrm{c} / 20$ & 0,025 \\
\hline
\end{tabular}

A verificação do cisalhamento (sétima e oitava coluna da tabela 5.8) foi feita para a situação esquematizada na figura 5.24.

\section{Cálcullo de Vo}

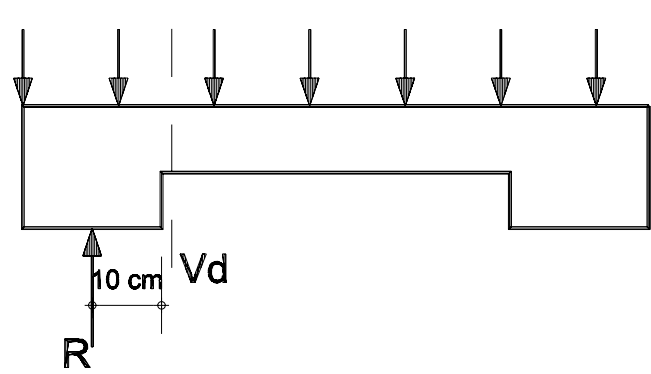

Cisalhamento

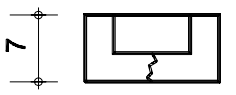

14 $\begin{array}{ll}\therefore & b=14 \mathrm{~cm} \\ \rightarrow & d=2 \mathrm{~cm}\end{array}$

Figura 5.24: Situação de cálculo da tensão de cisalhamento da verga

A última coluna da tabela 5.8 representa o valor da tensão de contato no apoio da viga sobre a parede. O valor admissível especificado por norma (NBR 10837) equivale a 0,25 da resistência do prisma (fp). Considerou-se a resistência do prisma $80 \%$ da resistência do bloco. O cálculo deve ser efetuado para a mínima resistência do bloco usado, ou seja, 4,5 $\mathrm{MPa}$, no caso de blocos de concreto, o que resulta em uma tensão máxima de contato igual a 0,9 MPa.

Como pode ser comprovado na tabela 5.8 , nenhuma tensão de contato atuante $\left(f_{\text {con }}\right)$ superou o valor admissível. 
A solicitação a que está submetida a verga é muito pequena, resultando nas armaduras longitudinal e transversal mínimas para todos os vãos. Uma possível disposição da armadura na peça de concreto é apresentada na figura 5.25.

A opção dos estribos abertos para absorver as forças cortantes soluciona o problema de falta de espaço na seção transversal da peça para o detalhamento da armadura transversal e segundo FUSCO (1995), eles são tão eficientes quanto os estribos fechados.

A armadura é de fácil execução; porém, atenta-se para o cuidado de respeitar o cobrimento de $1 \mathrm{~cm}$.

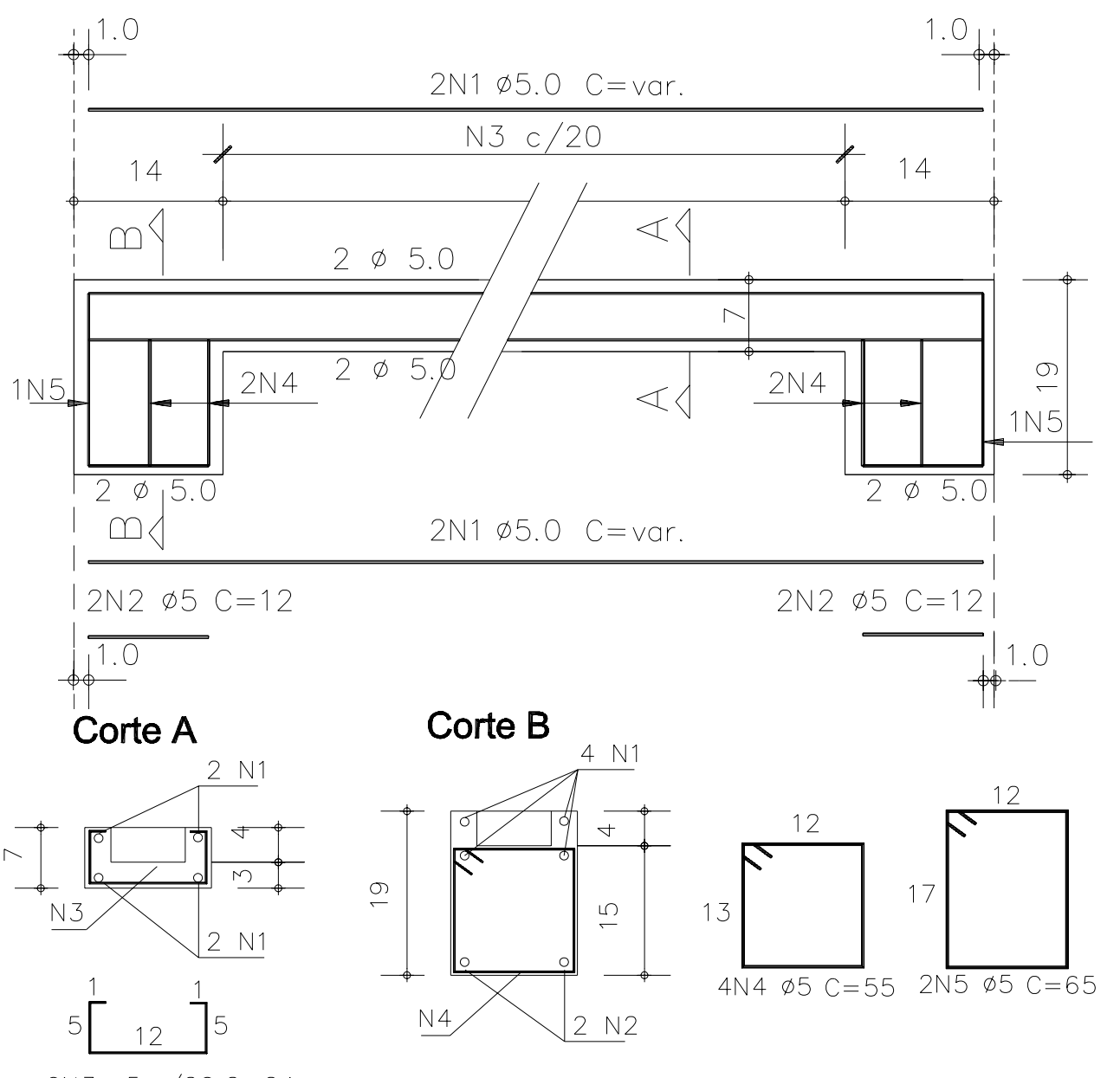

Figura 5.25: Detalhamento das armaduras da verga pré-moldada

O comprimento variável das armaduras longitudinais (N1) da figura 5.25 indica que o detalhamento pode ser adaptado para vergas de vários comprimentos, desde que sejam solicitadas como analisado neste item. 
É muito comum encontrar ao lado das portas, a passagem de conduites ou de armadura vertical. As vergas pré-moldadas, neste caso, não podem se tornar um obstáculo impedindo a passagem vertical; portanto, prever aberturas nos apoios das vergas pode ser necessário, como apresentado na figura 5.26.

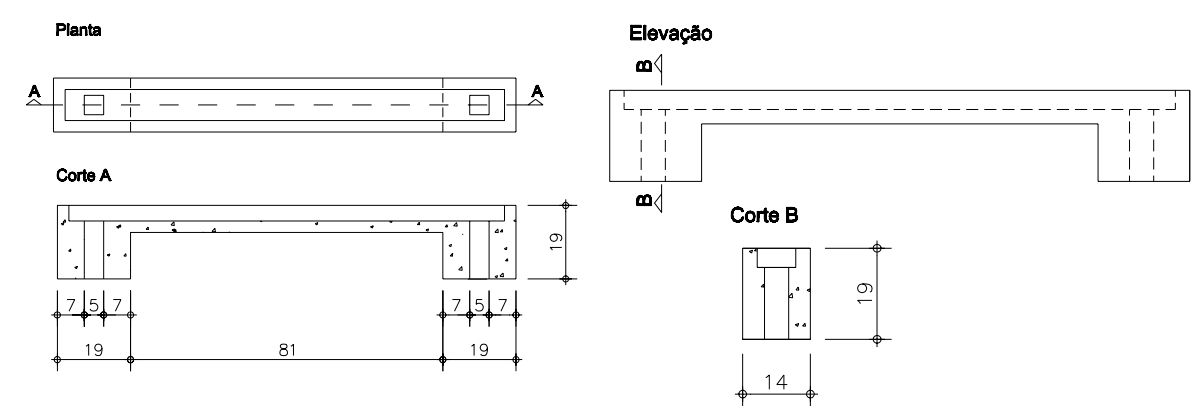

Figura 5.26: Verga com abertura nos apoios para passagem vertical

Haverá problemas também em projetos com portas adjacentes, em que um só bloco de apoio suporta duas vergas, como ilustrado na figura 5.27. A sugestão para resolver este problema é adaptar a dimensão de um dos apoios das vergas para meio bloco, como mostra a figura 5.28 .

\section{Elevação}

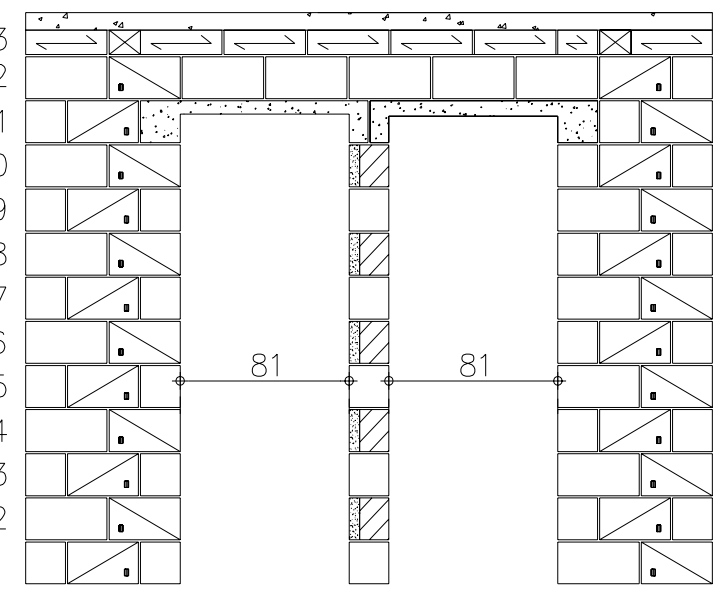

Figura 5.27: Elevação com portas adjacentes 


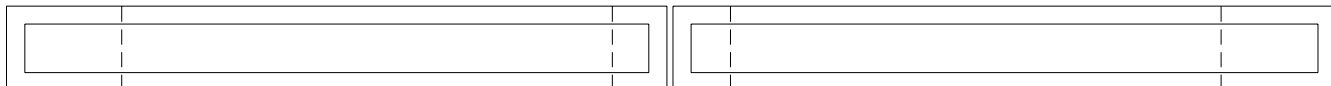

Elevação

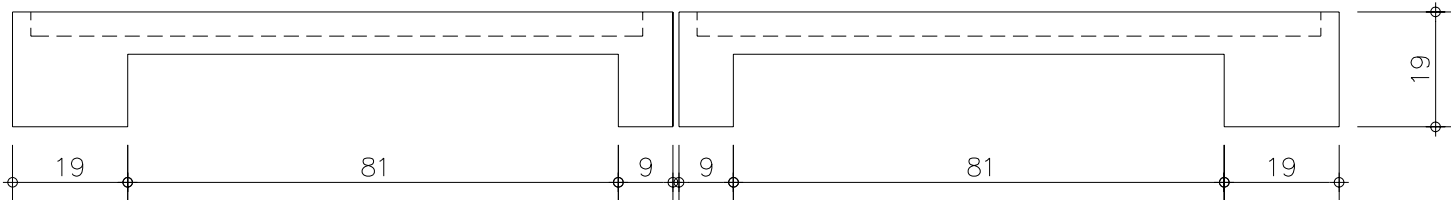

Figura 5.28: Vergas sobre portas adjacentes

As vergas pré-moldadas sobre portas adjacentes dispostas em interseções de paredes em "L" e em "T" (figuras 5.29 e 5.30) também precisam ter adaptações geométricas. Dois procedimentos são recomendados. O primeiro consiste em fazer um dente em uma das vergas e reduzir o apoio da outra, de modo que haja um encaixe (figura 5.31). A segunda solução é chanfrar a $45^{\circ}$ a extremidade das duas vergas (figura 5.32).

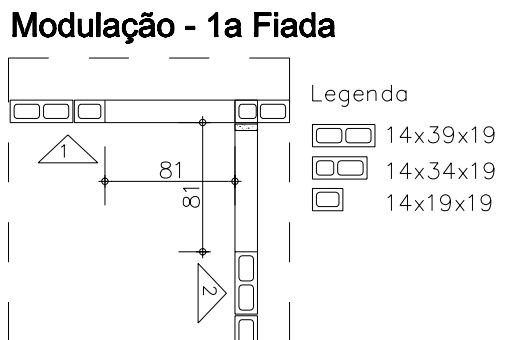

Figura 5.29: Planta esquemática de interseção em "L" entre paredes

Elevação 1

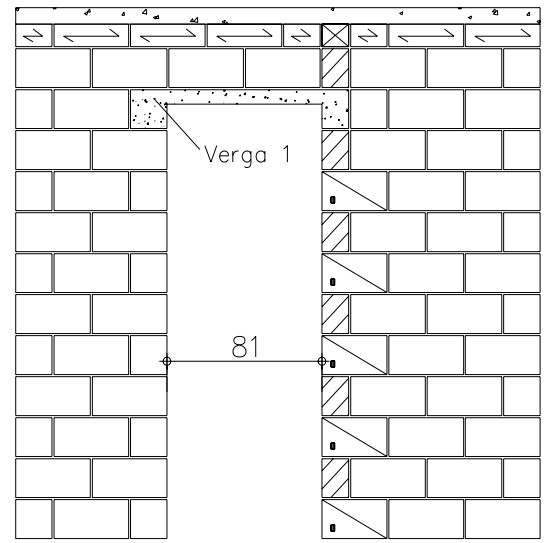

Elevação 2

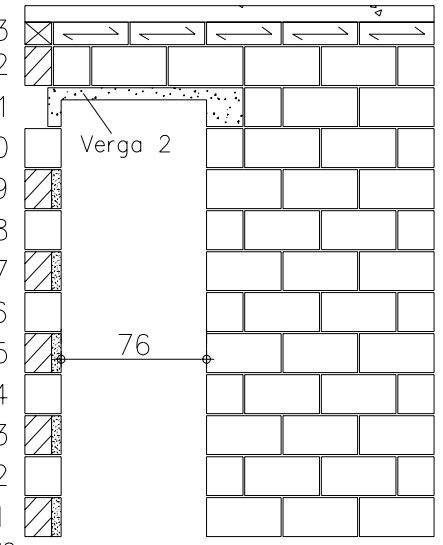

Figura 5.30: Elevação de paredes que se interceptam 


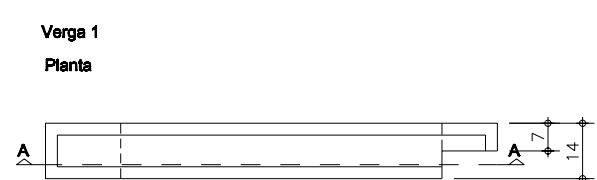

Corte A

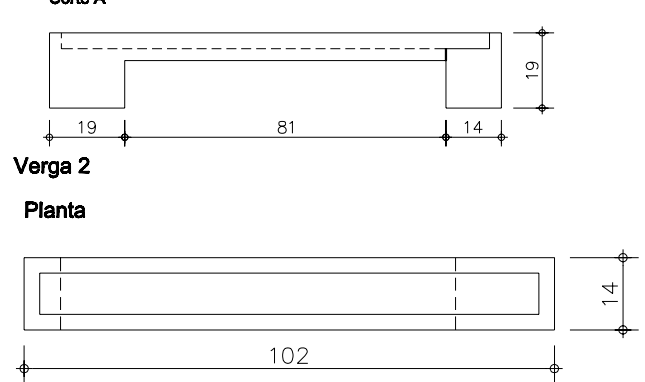

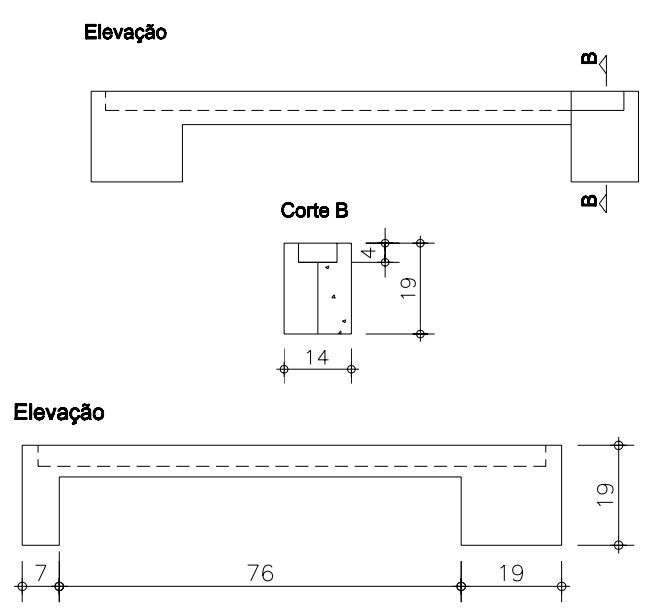

Figura 5.31:Vergas sobre portas adjacentes em "L" (ver figura 5.29)

Figura 5.32: Verga com chanfro de $45^{\circ}$ na extremidade para uso sobre portas adjacentes em "L"

Nos casos de vergas especiais com redução da área do apoio sobre os blocos, é recomendável verificar se a tensão de contato atuante não ultrapassa a admissível, como feito anteriormente na tabela 5.8. Para as geometrias de vergas especiais apresentadas neste trabalho, não foi constatado problema com a tensão atuante.

Apesar das vantagens obtidas com o emprego de vergas pré-moldadas, comentadas e analisadas anteriormente, muitos construtores ainda se mostram apreensivos quanto à sua adoção e preferem optar pelo procedimento tradicional de execução de verga, com o assentamento de blocos canaleta, seguido pelo posicionamento da armadura e grauteamento.

A execução de vergas com blocos canaleta em associação a portas padronizadas, como mostrado previamente na tabela 5.1, demanda ajustes altimétricos, que poderão ser feitos com elementos pré-moldados.

Os pré-moldados, aqui denominados de réguas de ajuste, são retangulares e contêm espessura equivalente ao valor de ajuste entre a altura da 
porta e a modulação da alvenaria, como ilustrado nas figuras 5.33 e 5.34 . A régua de ajuste é assentada quando a elevação da alvenaria atingir o nível da altura da porta.

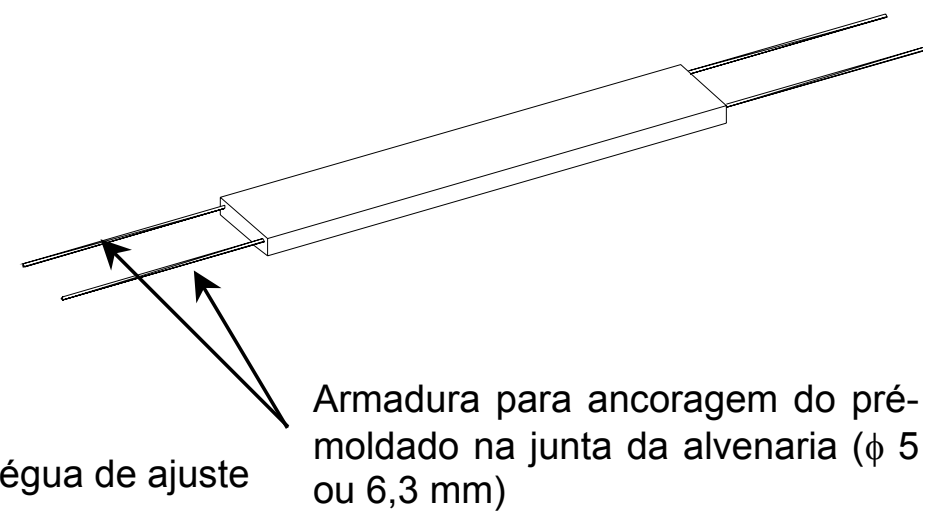

Figura 5.33: Régua de ajuste ou $6,3 \mathrm{~mm}$ )

As réguas de ajuste também podem funcionar como apoio para o assentamento dos blocos canaleta da verga, bastando um escoramento provisório no centro do vão.

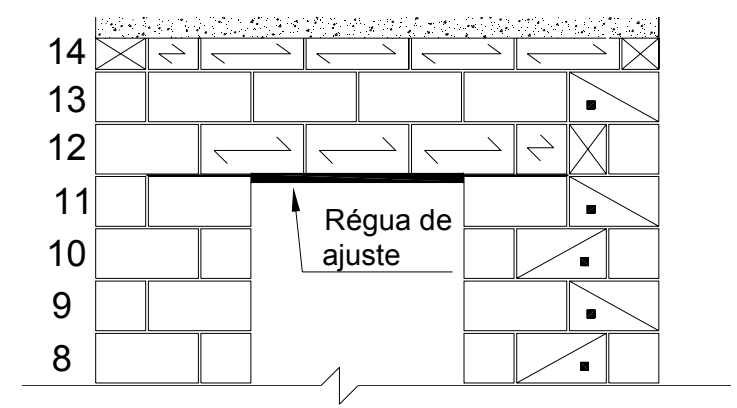

Figura 5.34: Representação da régua de ajuste na elevação da alvenaria

\subsubsection{Contraverga}

Contraverga é o componente estrutural colocado sob os vãos de aberturas das paredes, com a finalidade de absorver as tensões de tração cantos inferiores das aberturas.

O procedimento usual para a execução da contraverga em edifícios de alvenaria estrutural é o assentamento de blocos canaleta na fiada do peitoril da janela, posicionamento da armadura e grauteamento.

Muitas vezes, aproveita-se a existência de cintas à meia altura na alvenaria na quinta ou sexta fiada para a função de contraverga. 
Ressalta-se o cuidado em prever vazios nos cantos e bordas de intersecções de paredes para a correta passagem da armadura, conforme indicado na figura 5.35. Para o grauteamento dos blocos canaleta, os cantos deverão ser fechados com forma de madeira.

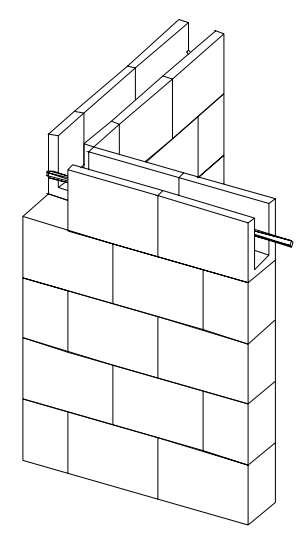

Figura 5.35: Abertura no canto da parede na cinta à meia altura propiciando a passagem da armadura

Outra opção para a consolidação de aberturas no encontro de paredes é o uso de blocos com entalhes, que facilitam o corte com a colher do pedreiro

\subsection{Contramarco Pré-moldado}

O contramarco pré-moldado é um quadro rígido delgado, que envolve o vão da abertura e a espessura da parede, e juntamente com a janela compõem a esquadria.

Ele é fixado na alvenaria com argamassa de assentamento por dois pedreiros, conforme mostrado na figura 5.36, durante a etapa de elevação da alvenaria, o que permite a conclusão total do serviço sem que haja quebras e enchimentos. 


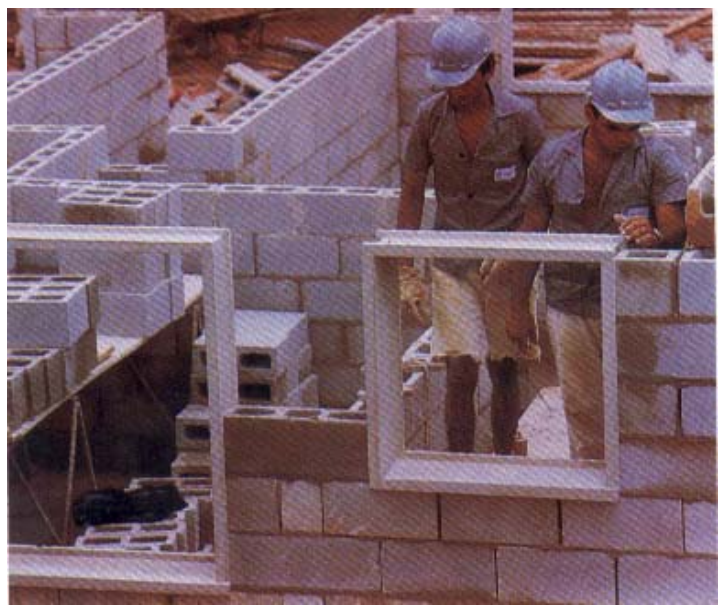

Figura 5.36: Assentamento de contramarco pré-moldado (Giassetti, 2000)

As dimensões de contramarcos para edifícios em alvenaria estrutural devem obedecer à modulação da alvenaria e concordar dimensionalmente com os componentes da edificação de interface.

Para atender à modulação, empregando-se blocos disponíveis no mercado, a dimensão externa dos contramarcos será de:

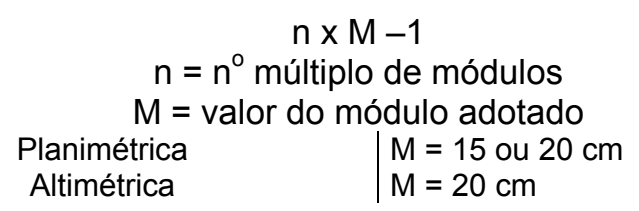

Há uma perda do vão livre da janela, em relação ao vão modular, causada pela espessura do contramarco. O valor da espessura é de aproximadamente $2 \mathrm{~cm}$, limitado pelo peso da peça.

Com o objetivo de melhorar a estanqueidade da janela, pode-se acrescentar à geometria do contramarco detalhes de pingadeiras, frisos, rebaixos, inclinações e saliências, como por exemplo, os contramarcos envolverem a alvenaria, estando salientes aos revestimentos externos, com avanço mínimo de $5 \mathrm{~mm}$, como esquematizado nos cortes da figura 5.37 .

O projeto do contramarco pré-moldado deve atentar para detalhes da seção transversal, considerando-se o tipo de janela a ser utilizada (fixa, basculante, de correr) e o valor do revestimento da parede executado pela construtora. Alguns valores usuais, como referência, são: $25 \mathrm{~mm}$ para revestimento com argamassa em 
paredes externas e $10 \mathrm{~mm}$ em paredes internas; e $15 \mathrm{~mm}$ para revestimentos internos cerâmicos.

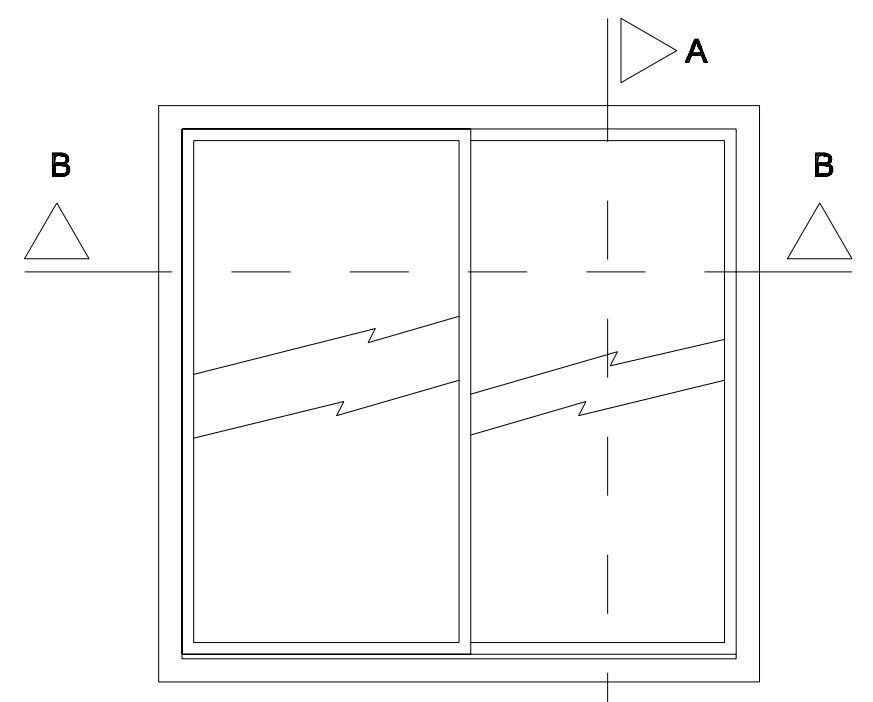

A

Vista frontal

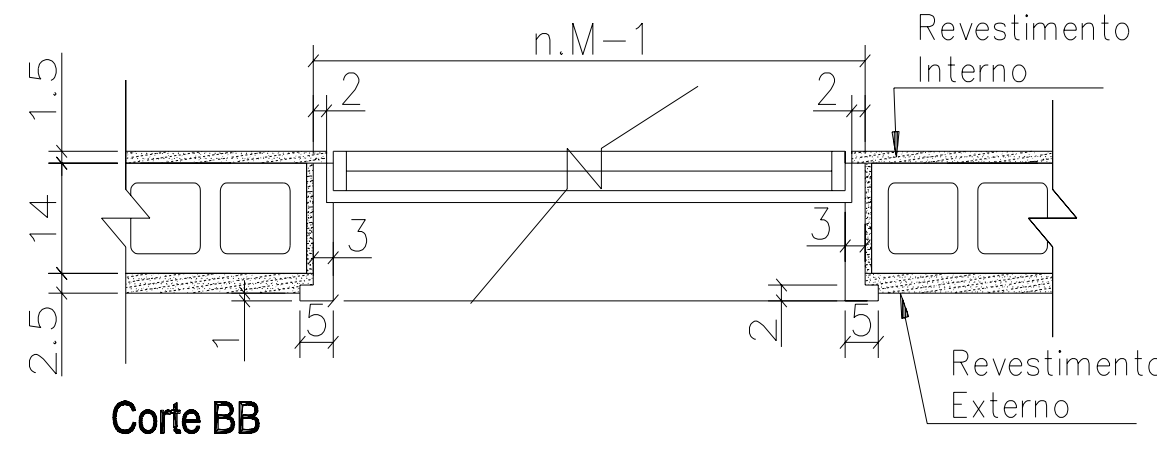

Figura 5.37: Vista frontal e cortes de esquadria composta por contramarco pré-moldado

Obs: No corte $A A$, o rebaixo do contramarco mede $5 \mathrm{~cm}$; no entanto, para venezianas de correr com 3 folhas, o rebaixo deve ser maior que $10 \mathrm{~cm}$.

As deformações excessivas dos contramarcos podem comprometer o funcionamento adequado das janelas metálicas. A ABNT (2000), "Caixilhos para edificações", limita a deflexão máxima instantânea para as esquadrias em L/175 do vão, sendo L o comprimento livre do perfil, não podendo exceder a $2 \mathrm{~cm}$. 
A norma de projeto e execução de concreto armado (ABNT, 1978) restringe o valor da flecha total em L/300 e o valor da flecha causada por ação de curta duração em L/500, sendo L o comprimento do vão teórico.

Para verificar se as dimensões internas dos pré-moldados estão em concordância com as tolerâncias dimensionais das janelas metálicas, sugere-se a utilização de um gabarito metálico.

Antes de prosseguir o assentamento dos blocos das fiadas superiores ao contramarco, é recomendado escorar a peça pré-moldada.

Os contramarcos podem ser armados com armadura discreta (barras e fios) ou armadura difusa (telas). As telas são fornecidas em rolos; portanto, a realização de um plano de corte otimiza sua utilização e proporciona redução dos desperdícios.

A colocação de espaçadores é fundamental para garantir o cobrimento especificado, principalmente em regiões com concentração de armadura e nos cantos, onde há tendência de deslocamento.

A incorporação de fibras à matriz de concreto é uma prática consagrada atualmente entre os fabricantes de peças pré-moldadas de pequena espessura. As fibras agem como micro-armaduras ajudando a controlar a fissuração por retração hidráulica.

As telas soldadas, freqüentemente empregadas para reduzir a fissuração, principalmente em elementos de pequena espessura como os contramarcos, podem ser substituídas por adições de fibras, ganhando-se com a redução no peso.

As fibras também propiciam acréscimo de resistência ao impacto, aspecto positivo para peças sujeitas ao transporte. No entanto, elas reduzem a trabalhabilidade da pasta de concreto; portanto, são necessários cuidados na dosagem dos materiais da mistura.

A espessura reduzida dos contramarcos, em torno de $2 \mathrm{~cm}$, propicia o emprego da tecnologia da argamassa armada. 
Algumas indicações de parâmetros característicos de dosagem e algumas propriedades da argamassa armada são apresentadas na tabela 5.9, com base na experiência do grupo de São Carlos, extraídos de HANAI (1992).

Tabela 5.9: Parâmetros característicos e dosagem de argamassas e suas propriedades, baseados na experiência do grupo de São Carlos (HANAI, 1992).

\begin{tabular}{|c|c|c|}
\hline & Parâmetros característicos & Valores sugeridos \\
\hline \multirow{3}{*}{ 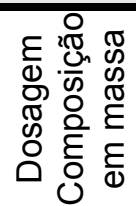 } & consumo de cimento & 500 a $680 \mathrm{~kg} / \mathrm{m}^{3}$ \\
\hline & relação água/cimento & 0,35 a 0,45 \\
\hline & relação agregado miúdo/cimento & 2 a 3,2 \\
\hline \multirow{3}{*}{ 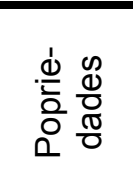 } & consistência: índice "flow-table" & 160 a $220 \mathrm{~mm}$ \\
\hline & resistência à compressão* & $25 \mathrm{MPa}$ a $50 \mathrm{MPa}$ \\
\hline & peso específico & 2200 a $2400 \mathrm{~kg} / \mathrm{m}^{3}$ \\
\hline
\end{tabular}

* Avaliada por meio de ensaio à compressão simples de corpos-de-prova cilíndricos de $50 \mathrm{~mm}$ de diâmetro e $100 \mathrm{~mm}$ de altura.

"Em geral, deseja-se uma argamassa de consistência plástica, com baixa relação água/cimento, de tal maneira que a permeabilidade seja a mais baixa possível, para se assegurar adequada proteção das armaduras e durabilidade; deseja-se também menor retração hidráulica e fluência e resistência mecânica elevada, sobretudo na tração" (HANAl, 1992).

Como uma sugestão inicial de caráter prático, indica-se a composição do traço de referência em massa:

- 1 parte de cimento;

- $\quad$ 1,6 parte de areia média;

- $\quad$ 1,2 parte de pedrisco (diâmetro máximo característico 4,8 a 6,3 mm);

- $\quad$ relação água/cimento: 0,432 (sem aditivo plastificante).

Esta composição é utilizável em grande parte dos casos, mas está sujeita aos fundamentais ajustes, em função dos materiais disponíveis.

Os contramarcos também exercem a função de acabamento das janelas, além de comporem a estética da fachada; portanto, devem apresentar aparência satisfatória. Após a desmoldagem, as peças devem receber um acabamento superficial para preencher os vazios causados por bolhas de superfícies ou reparar pequenas quebras. 
Em ambientes agressivos, prever maior proteção das peças, como por exemplo com pinturas especiais.

O processo de instalação do contramarco é simples e pode ser executado por um pedreiro e um ajudante e é constituído das etapas:

- $\quad$ elevação da alvenaria até a fiada acima do parapeito;

- posicionamento manual do contramarco e fixação provisória;

- alinhamento, nivelamento e verificação do prumo, e

- $\quad$ preenchimento das juntas com argamassa de assentamento.

É recomendado identificar a correta posição de assentamento dos contramarcos, principalmente, com indicações da face externa e interna, evitando-se a troca (equívoco) pelo pedreiro.

O sistema de contramarco pré-moldado em argamassa armada era adotado pela construtora ENCOL, cujo processo de instalação está descrito no relatório técnico do Manual do Processo Construtivo POLI-ENCOL (FRANCO et alii, 1991c), esquematizado na figura 5.38 .

O processo é similar ao descrito acima; porém, a alvenaria era executada até a sétima fiada, pois nesta etapa, o serviço deveria ser interrompido para o posicionamento de andaimes; a seguir, o contramarco era posicionado na abertura e fixado provisoriamente com auxílio de uma ferramenta especial de sustentação denominada "sargento" (figura 5.38b).

Os sargentos permitiam acertos geométricos do pré-moldado com segurança contra queda.

Feita a fixação provisória, prosseguia-se com alinhamento, nivelamento e verificação do prumo, enchimento das frestas entre o contramarco e a alvenaria, com argamassa, retirada dos sargentos e continuação da elevação da alvenaria. As etapas estão ilustradas na figura 5.38 . 


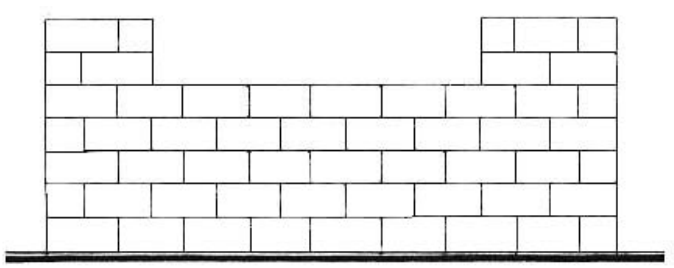

a) elevação da alvenaria até a sétima fiada

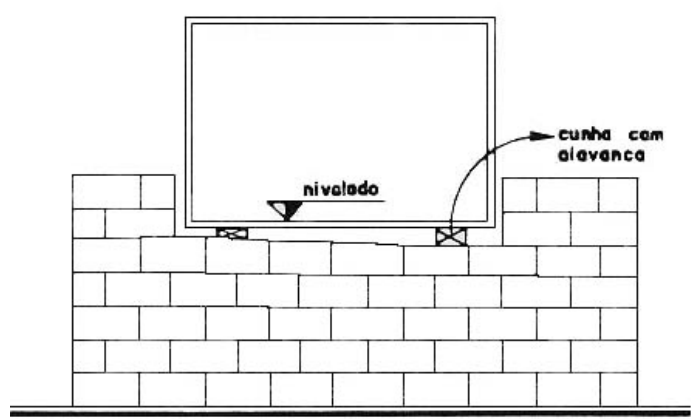

c) nivelamento por encunhamento

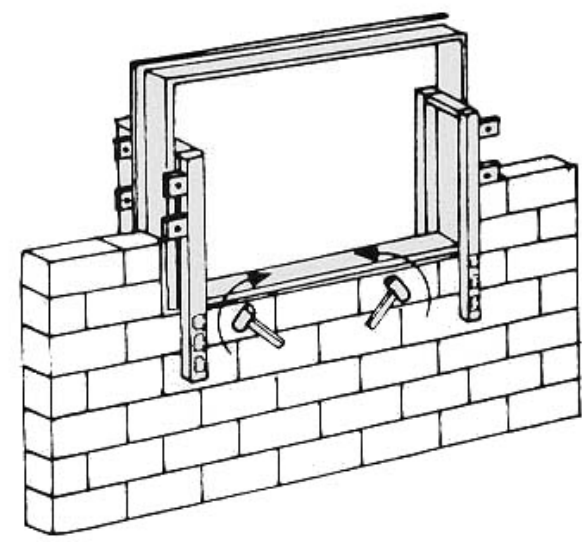

b) posicionamento do sargentos $\mathrm{e}$ alinhamento da travessa inferior

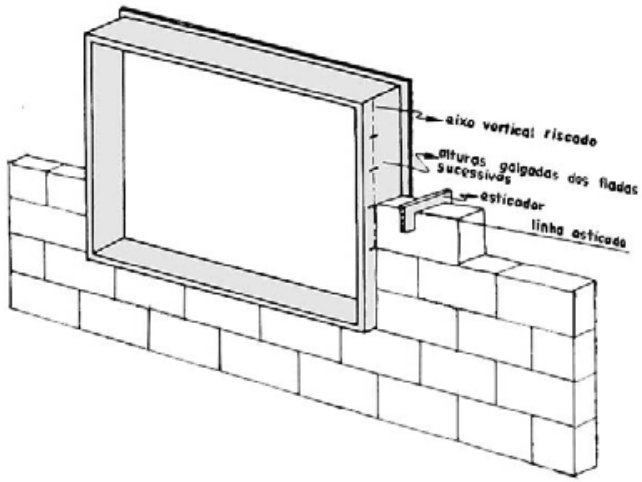

d) prosseguimento do assentamento da alvenaria usando o contramarco como referência

Figura 5.38: Etapas para o assentamento do contramarco pré-moldado adotado pela ENCOL (FRANCO et alii, 1991c)

As fases de projeto e planejamento são de vital importância para o sucesso da aplicação dos contramarcos pré-moldados. As dimensões dos vãos das aberturas devem ser preferencialmente padronizadas, com pouca variação, de modo que haja o menor número de formas e detalhamentos diferentes. O ritmo de produção dos elementos deve estar em concordância com a demanda de peças a serem instaladas durante a elevação da alvenaria.

Após a fixação, o contramarco ainda pode servir de gabarito para o assentamento das fiadas posteriores de blocos, como na figura $5.38 \mathrm{~d}$.

As janelas podem ser instaladas no contramarco com buchas plásticas e parafusos ou com poliuretano, em uma etapa posterior à finalização dos revestimentos, evitando, com isto, que sejam danificadas. 
A janela parafusada deve ter dimensões compatíveis com as dimensões internas do contramarco, com o mínimo ajuste.

A geometria do contramarco ajuda no sistema de vedação; no entanto, é recomendável que uma película de vedação seja aplicada na interface entre a janela e o contramarco.

O silicone de cura neutra adere à maioria das superfícies, inclusive de alumínio, vidro e concreto, faz vedação à prova d'água, é flexível e não se altera na presença de radiação ultravioleta. Para a movimentação da esquadria, deve-se cumprir o prazo de espera de 7 dias para a cura do silicone.

A janela instalada com espuma de poliuretano também deve estar parafusada no contramarco.

$\mathrm{Na}$ fase final da obra, após a execução do acabamento, a janela é nivelada, aprumada, fixada com parafuso e espuma de poliuretano. Os parafusos manterão a janela posicionada corretamente até a cura do poliuretano (cerca de 4 a 8 horas). Após a cura, retirar com uma espátula, o excesso de espuma e colocar a guarnição interna à esquadria.

Deve ser deixada uma distância entre a janela e o contramarco pré-moldado de $1 \mathrm{~cm}$ de cada lado para a aplicação do poliuretano.

A proteção da espuma contra os raios UV é garantida por um rebaixo no próprio perfil do contramarco (figura 5.37).

Atualmente, já são encontrados comercialmente os contramarcos pré-moldados.

Uma opção oferecida por um dos fabricantes é a produção isolada de travessas e montantes que, após a solidarização, constituirão o contramarco, como ilustrado na figura 5.39. 


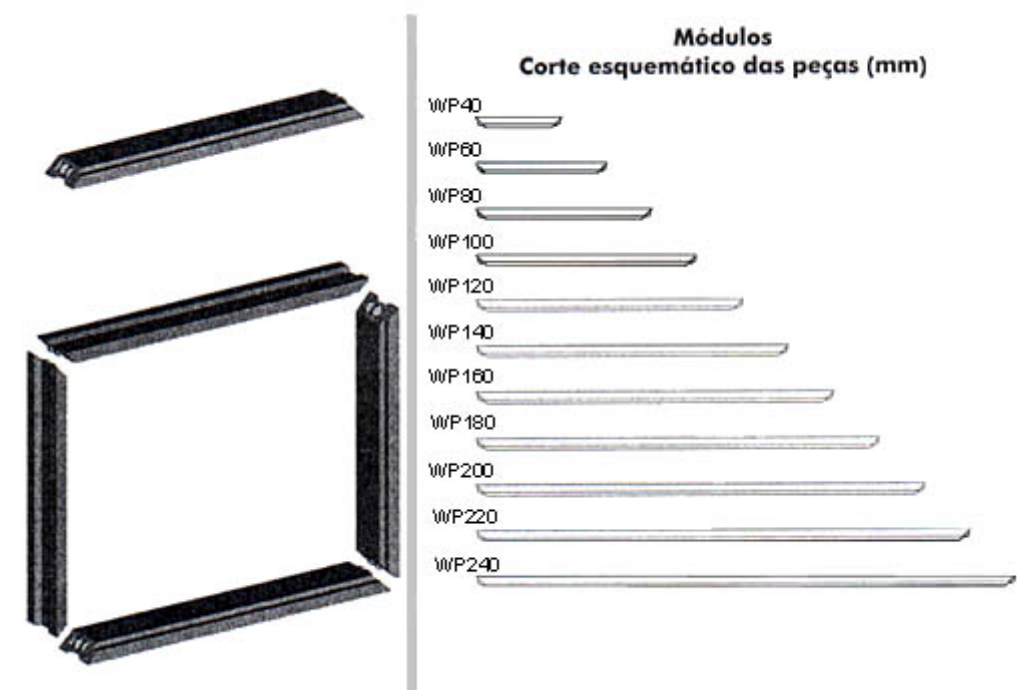

Figura 5.39: Contramarco formado por travessas e montantes produzidos isolados (WINBLOCK, 1999)

O contramarco, formado a partir de peças pré-moldadas independentes, permite a formação de diversos módulos com melhor aproveitamento das formas.

A solidarização entre as travessas e os montantes, garantida pelo fabricante, é por meio de silicone para juntas de dilatação em conjunto com um pino de encaixe, como detalhado na figura 5.40 .

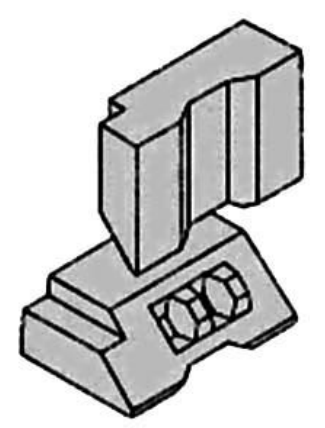

Figura 5.40: Detalhe de encaixe entre as travessas pré-moldadas do contramarco (WINBLOCK, 1999) 


\subsection{Ajuste Dimensional}

Neste item, são abordados os elementos pré-moldados leves que não têm função estrutural mas que se tornam fundamentais inseridos no processo construtivo em alvenaria estrutural, ao contribuírem com a racionalização.

\subsubsection{Caixas Suporte de Aparelhos de Ar Condicionado}

No projeto de edifícios habitacionais, principalmente aqueles localizados em regiões de clima quente, há a previsão do local destinado à instalação de aparelhos de ar condicionado.

Geralmente, os aparelhos utilizados em edifícios habitacionais são classificados como do tipo janela, ou seja, são instalados embutidos na parede com o corpo do aparelho externo à edificação, sustentado por um suporte que pode ser uma estrutura metálica ou uma caixa de argamassa armada.

A caixa em argamassa armada, ilustrada na figura 5.41 , além de sustentar o aparelho, também o protege. Comparada com a estrutura metálica, exposta às intempéries, as caixas em argamassa armada apresentam maior durabilidade, sem necessidade de manutenção periódica.

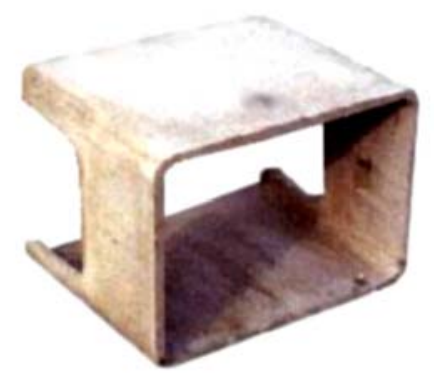

Figura 5.41: Caixa para ar condicionado

Em casas comerciais de artefato à base de cimento ou em fábricas produtoras de pré-moldados leves, são comumente comercializadas as caixas suporte de ar condicionado industrializadas; no entanto, as dimensões disponíveis para este componente são determinadas a partir das dimensões dos aparelhos elétricos, não sendo feita compatibilização com a modulação da alvenaria. 
Portanto, adquirir as caixas suporte de ar condicionado comerciais e destiná-las para uso em edifícios de alvenaria estrutural, implica em enchimentos entre o pré-moldado e a parede, em função da incompatibilidade dimensional das caixas e da modulação da alvenaria.

A alternativa para eliminar os enchimentos é encomendar as peças pré-moldadas para os fabricantes com as dimensões necessárias, o que poderá elevar demasiadamente o custo, ou produzir as caixas suporte no próprio canteiro de obra.

A produção é extremamente simples, pois conta com a geometria retangular do elemento, sem muitos recortes. A figura 5.42 ilustra uma forma metálica da caixa produzida no canteiro de obra e o aspecto da caixa assentada na alvenaria.
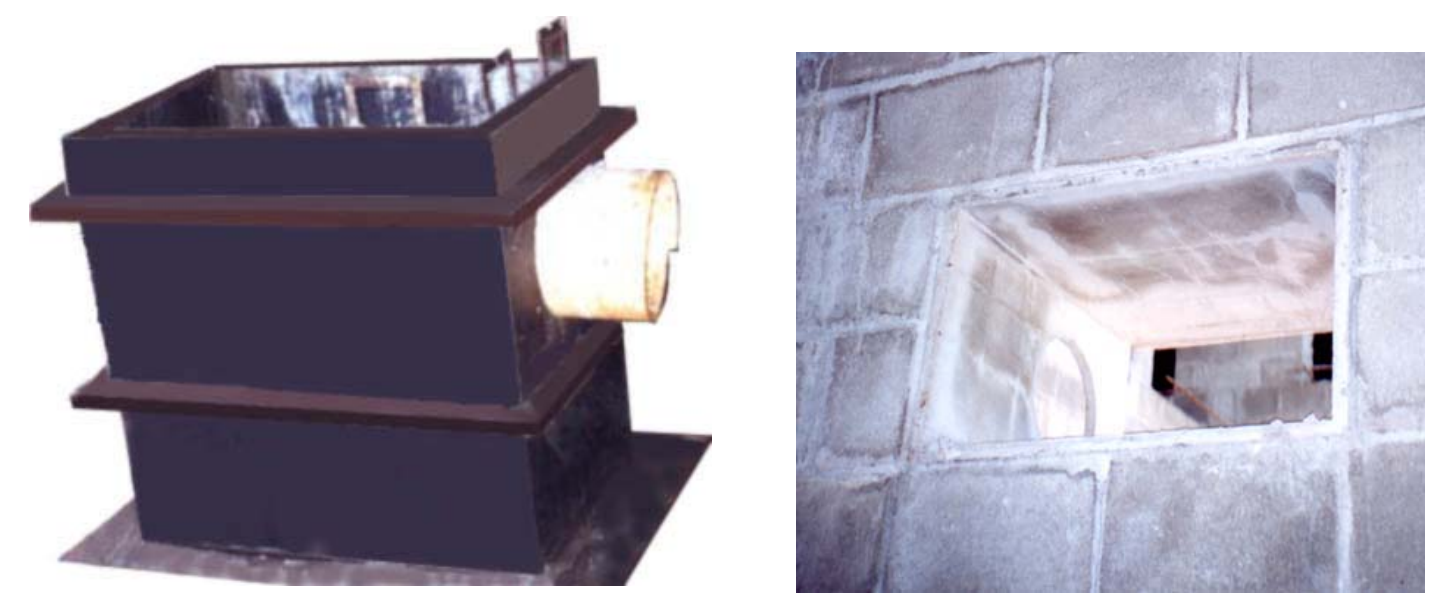

Figura 5.42: Forma para caixa suporte de ar condicionado - produção no canteiro da obra [a]; e aspecto da caixa de ar condicionado assentada na alvenaria [b]

A adoção de forma metálica proporciona aspecto estético com superfícies lisas e regulares, dimensões exatas e grande número de reutilizações.

Para definir as dimensões externas da caixa, prevendo-se assentamento com juntas de argamassa de $1 \mathrm{~cm}$, adotar:

$$
\mathrm{n} \times \mathrm{M}-1 \quad \mid \begin{aligned}
& \mathrm{n}=\mathrm{n}^{\circ} \text { de módulos } \\
& \mathrm{M}=\text { valor do módulo adotado }
\end{aligned}
$$


Ressalta-se que as dimensões internas devem ser suficientes para acomodar os aparelhos. As dimensões usuais dos aparelhos situam-se em uma faixa de:

$$
45 \mathrm{~cm}<\text { largura }<65 \mathrm{~cm} \quad 30 \mathrm{~cm}<\text { altura }<40 \mathrm{~cm}
$$

\subsubsection{Elementos Vazados Modulares de Concreto}

Nas fachadas das edificações, os arquitetos procuram obter um aspecto arquitetônico inovador e agradável, mas geralmente em edifícios de habitação popular, para reduzir os custos, acaba-se restringindo a arquitetura de fachada a pequenos detalhes diferenciais.

Em edifícios de alvenaria estrutural, o problema é agravado, pois a estrutura portante são as próprias paredes do edifício que, por sua vez, devem estar preferencialmente amarradas.

A composição de elementos vazados modulares de concreto nas fachadas de edificações tornam-se diferenciais na arquitetura, como ilustra a figura 5.43 .
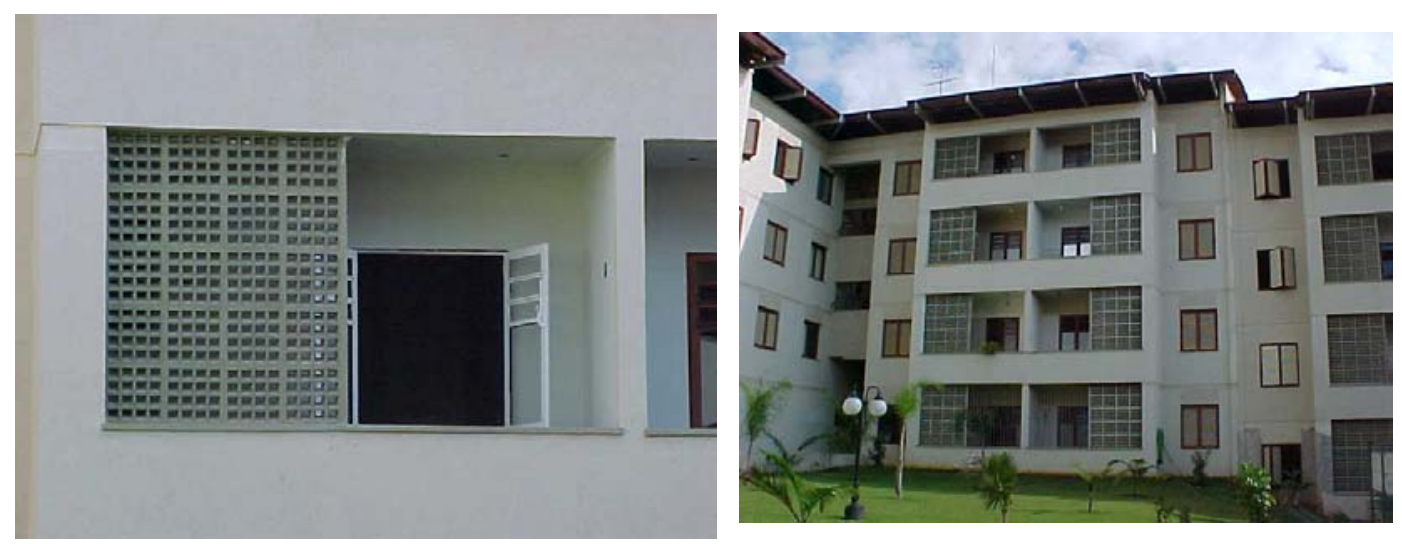

Figura 5.43: Foto da fachada de um edifício em alvenaria estrutural com aplicação de elementos vazados modulares de concreto

Estes elementos de concreto não apresentam função estrutural, apenas função estética; no entanto, têm dimensões modulares em concordância com a modulação da alvenaria, fator importante para a racionalização do processo. São 
produzidos por empresas fabricantes de pré-moldados leves e assentados conjuntamente com os blocos usando o mesmo procedimento.

\subsubsection{Peças Compensadoras de Ajuste Dimensional}

Há casos que, por imposições arquitetônicas, torna-se difícil aplicar os procedimentos executivos para instalação de esquadrias, demonstrados neste trabalho, sem a presença de enchimentos, como por exemplo, para a instalação de portas de madeira:

\begin{tabular}{ll}
\hline módulo adotado & $\mathrm{BL}-20$ \\
dimensão da porta especificada pelo arquiteto & $80 \mathrm{~cm}$ \\
dimensão do vão na alvenaria & $101 \mathrm{~cm}$ \\
dimensão total da esquadria (folha+batente+instalação) & $91 \mathrm{~cm}$ \\
ajuste dimensional & $10 \mathrm{~cm}$ \\
\hline & \\
\hline & $\mathrm{BL}-15$ \\
módulo adotado & $70 \mathrm{~cm}$ \\
dimensão da porta especificada pelo arquiteto & $91 \mathrm{~cm}$ \\
dimensão do vão na alvenaria & $81 \mathrm{~cm}$ \\
dimensão total da esquadria (folha+batente+instalação) & $10 \mathrm{~cm}$ \\
\hline
\end{tabular}

Outro exemplo é de janela com dimensões incompatíveis com a modulação da alvenaria.

Alguns elementos pré-moldados podem ser utilizados para prover a compatibilização das dimensões dos componentes, sem que se recorra aos enchimentos.

Estes elementos são popularmente denominados de "rapaduras" devido ao seu formato, (ver figura 5.44a) e sua utilização é tão visada que até algumas empresas produtoras de blocos já os estão fornecendo; no entanto, a simplicidade de produção permite que sejam moldados no canteiro da obra.

Ressalta-se, no entanto, que as rapaduras assentadas com juntas a prumo na alvenaria, ao longo do tempo, podem descolar-se ou apresentar fissuras nas juntas, pois estão sujeitas ao impacto das portas ou janelas.

Para evitar o mau funcionamento do sistema, pode-se optar por amarrar as rapaduras na alvenaria (figura $5.44 a$ ) ou substituí-las por réguas parafusadas à alvenaria (figura $5.44 \mathrm{~b}$ ). 


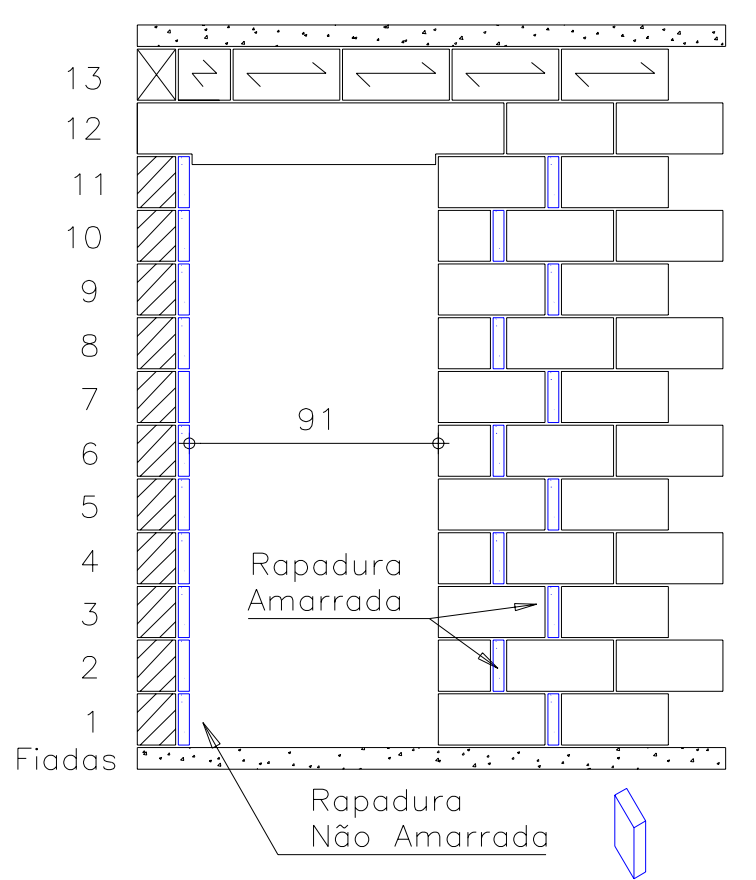

a) Ajuste com rapadura

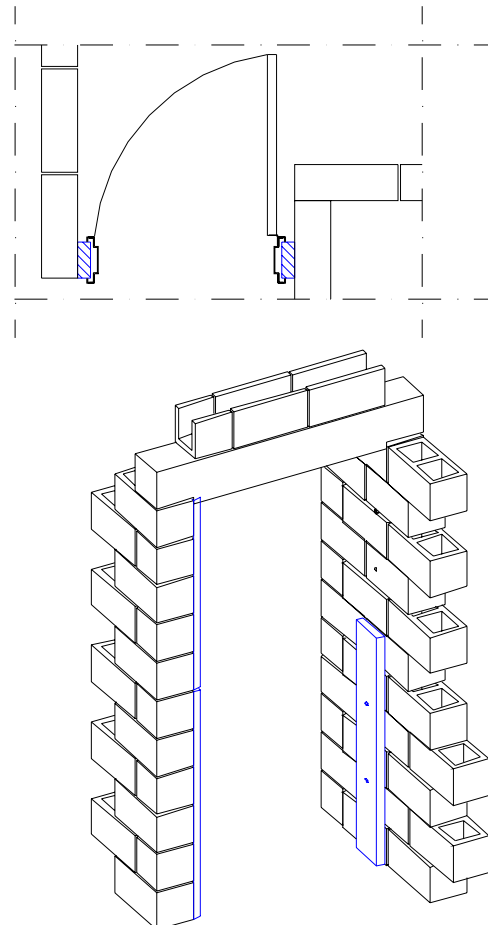

b) ajuste com régua

Figura 5.44: Ajuste na dimensão do vão da porta com rapadura [a]; e ajuste com régua parafusada $[\mathrm{b}]$

Outro exemplo em que podem ser usadas peças compensadoras de ajuste dimensional é dos edifícios com a laje moldada no local sobre bloco canaleta, onde ocorre uma interrupção no valor do módulo altimétrico, pois geralmente as lajes do pavimento em concreto armado têm espessuras inferiores a $20 \mathrm{~cm}$.

A descontinuidade da modulação altimétrica traz problemas nas regiões de escada, que geralmente são resolvidos com enchimentos em graute no local. No entanto, este processo pode tornar-se racionalizado com a adoção de elementos pré-moldados de ajuste.

A figura 5.45 representa elevações da caixa de escada, demonstrando a solução convencional e uma solução com uso de pré-moldados: escada jacaré e elementos de ajuste altimétrico. 


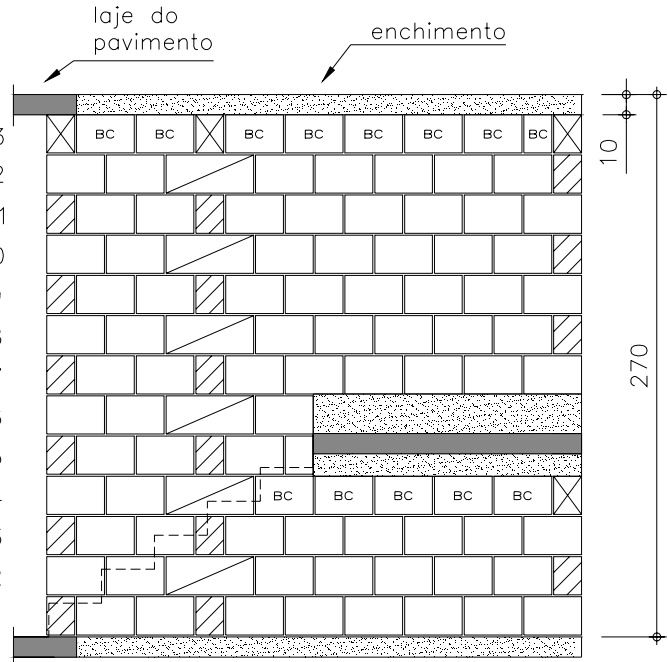

a) Elevação com enchimentos

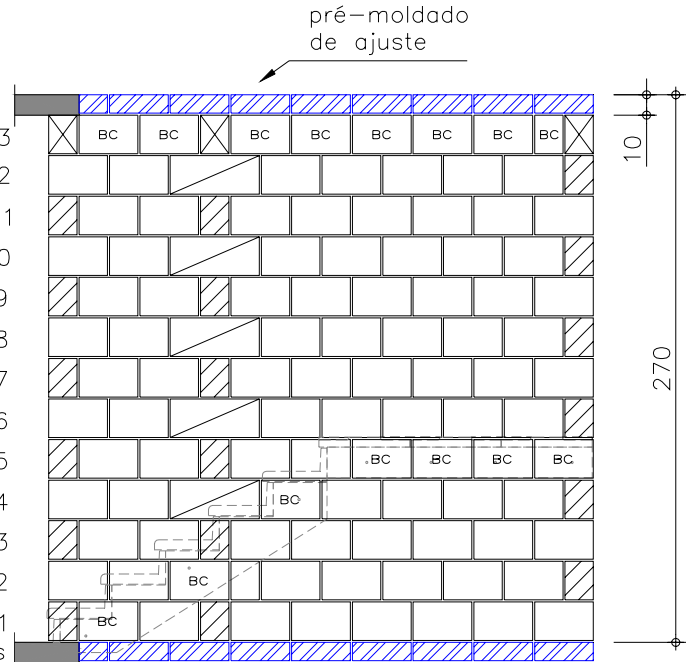

b) Elevação com uso de pré-moldados Legenda

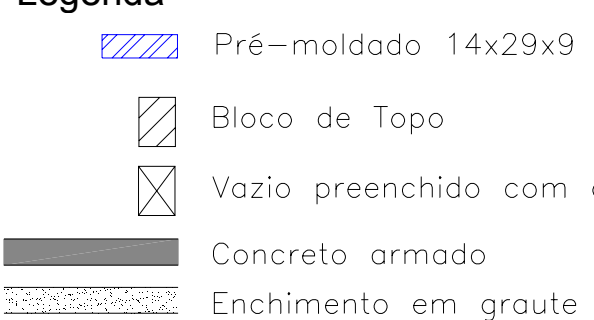

Figura 5.45: Elevação da alvenaria da região da escada com solução usando enchimentos [a]; e solução com pré-moldados [b]

\subsection{Considerações Finais}

Considerando-se a quantidade elevada de aberturas existentes em uma edificação residencial e as inúmeras interferências que elas causam no processo de elevação da alvenaria, pode-se dizer que a coordenação dimensional entre a alvenaria e as aberturas, principalmente para instalação de esquadrias, merecem ser estudadas e analisadas com bastante atenção.

Neste capítulo, foram apresentadas as esquadrias usualmente utilizadas em edifícios habitacionais e os procedimentos executivos racionalizados para sua instalação. Baseando-se nas informações de apresentação, foram elaborados quadros comparativos com as vantagens e desvantagens de cada procedimento executivo, permitindo, desta forma, a análise e a escolha da melhor solução a adotar. 
Dentre as proposições de esquadrias está a janela fixada ao contramarco pré-moldado de argamassa armada. Por se tratar de pré-moldado leve, os contramarcos receberam atenção especial e foram analisados nos aspectos dimensionais, geométricos, de produção e do procedimento de assentamento.

A coordenação dimensional entre as aberturas na alvenaria e as esquadrias foi atentamente discutida e quando necessário, propôs-se uso de elementos pré-moldados, para que os ajustes sejam executados de maneira racionalizada, sem a quebra de blocos ou enchimentos posteriores. Esses elementos são: vergas, pingadeiras, réguas de ajuste e rapaduras.

As vergas são elementos estruturais essenciais à edificação para evitar o surgimento das fissuras, como foi comprovado neste mesmo capítulo, com os resultados da simulação teórica em elementos finitos do comportamento das aberturas em alvenarias estruturais.

A adoção de vergas pré-moldadas, além de promover a distribuição das tensões na alvenaria, possibilita que o ajuste dimensional seja incorporado a sua geometria e aumenta a produtividade de execução da alvenaria, por não quebrar o ritmo da produção.

O estudo das vergas pré-moldadas foi enfatizado à vista dos benefícios por ela trazidos e, portanto, foram analisadas geometrias especiais para portas adjacentes, passagem de conduites e portas em "L". Também apresentou-se um exemplo de dimensionamento, como referência, podendo-se chegar a situações de detalhes padronizados de armaduras, que são de fácil execução.

Visando à racionalização do sistema com a coordenação modular, propôs-se a execução de caixas suporte de ar condicionado com dimensões compatíveis à modulação da alvenaria; e elementos vazados modulares como artifício arquitetônico de fachada. 


\title{
6. PRODUÇÃO DOS PRÉ-MOLDADOS
}

\author{
produção dos pré-moldados merece atenção especial, pois se
realizada sem controle pode pôr a perder todo um projeto bem
} elaborado, trazer patologias à edificação e até comprometer a segurança estrutural do elemento.

Neste capítulo, serão abordados os temas: transporte; fluxograma; controle da qualidade da produção e materiais alternativos.

O controle da produção é analisado por etapas: formas, armação, adensamento, cura, inspeção final, transporte e armazenamento.

O conhecimento de adições, como as fibras, ou materiais alternativos (agregados leves ou reciclados) para a confecção do concreto ou argamassa, são de grande interesse para a produção dos pré-moldados, pois podem melhorar a eficiência do elemento ou obter a redução dos custos.

Os blocos de concreto são classificados como pré-moldados leves; no entanto, suas características de produção são particulares, com dosagens adequadas e equipamentos próprios, merecendo um trabalho específico sobre o tema.

As informações apresentadas a seguir são coletâneas extraídas de trabalhos específicos sobre os temas abordados. 


\subsection{Transporte e Manuseio}

O transporte e o manuseio dos elementos pré-moldados leves podem ser efetuados por processo manual ou por meio de equipamentos auxiliares, como paletes, elevadores e gruas de pequeno porte.

Portanto, uma caracterização do transporte depende do tipo de processo ou dos equipamentos adotados.

Quando a opção for por transporte manual, os apectos mais importantes são os ergonômicos, pois o bem-estar e a capacidade física do operário são os fatores limitantes. Já quando são adotados equipamentos, as especificações e a sua correta operação é que são os fatores importantes, se considerar que os aspectos ergonômicos já foram estudados durante a concepção dos equipamentos.

\subsubsection{Ergonomia}

A ergonomia é definida de forma abreviada por GRANDJEAN (1991), como a "ciência da configuração do trabalho adaptada ao homem". O alvo da ergonomia é o desenvolvimento de bases científicas para a adequação das condições de trabalho às capacidades e realidades da pessoa que trabalha.

Segundo IIDA (1973), "a ergonomia parte do conhecimento do homem para fazer o projeto do trabalho, ajustando-o às capacidades e limitações humanas" e os objetivos práticos da ergonomia são a segurança, a satisfação e o bem-estar dos trabalhadores no seu relacionamento com sistemas produtivos; a eficiência virá como resultado.

O campo de aplicação de estudos ergonômicos na Construção Civil é extremamente vasto e engloba os postos de trabalho, as condições posturais dos operários perante uma atividade, a capacidade física do trabalhador, dentre outros.

Neste trabalho, por se estar priorizando o uso de elementos pré-moldados leves manuseados sem o auxílio de equipamentos de içamento, dar-se-á maior ênfase aos aspectos ergonômicos relacionados ao levantamento de peso. 
A capacidade física do homem é um problema complexo, em conseqüência da variação dos seres humanos. As pesquisas relacionadas a este tema fornecem princípios gerais e medidas básicas do desempenho humano, que devem ser adaptados para cada situação em particular, para produzirem resultados satisfatórios.

A norma regulamentadora de segurança e saúde do trabalhador (MINISTÉRIO DO TRABALHO, 1999), restringe o peso máximo carregado por um homem adulto em 60 quilos, por uma distância máxima de 60 metros.

O pesquisador de ergonomia, GRANDJEAN (1991), publicou várias referências sobre os limites de levantamento de cargas, dentre as quais duas se destacaram pelas vantagens de serem relativamente simples e de fácil aplicação prática: a do Instituto Nacional de Saúde e Segurança Ocupacional (NIOSH National Institute of Occupational Safety and Health) e a da Organização Internacional do Trabalho.

O NIOSH baseou-se nos valores limites para a força de compressão dos discos intervertebrais, chegando-se a cargas máximas de 40 a 50 kg, conforme a distância das mãos para o corpo.

As recomendações da Organização Internacional do Trabalho de 1969 prescrevem valores limites para levantamento de cargas, segundo a tabela 6.1.

Tabela 6.1: Limites de cargas (em $\mathrm{kg}$ ) segundo indicações da Organização Internacional do Trabalho (OIT), 1969.

\begin{tabular}{|l|c|c|c|c|}
\hline & \multicolumn{2}{|c|}{ Adultos } & \multicolumn{2}{c|}{ Jovens } \\
\cline { 2 - 5 } & Homens & Mulheres & Estudantes & Meninas \\
\hline Eventualmente & 50 & 20 & 20 & 15 \\
\hline Freqüentemente & 18 & 12 & $11-16$ & $7-11$ \\
\hline
\end{tabular}

Fonte: GRANDJEAN, 1991.

GRANDJEAN (1991) acrescenta, ao afirmar que "todos os valores limites até agora apresentados para o levantamento de cargas devem ser tomados apenas como orientação geral, e não oferecem, sob nenhuma condição, uma segurança absoluta de evitar complicações de coluna". 
Neste trabalho, baseado na bibliografia técnica apresentada e em entrevistas a especialistas de segurança do trabalho ${ }^{1}$, será adotado o valor de 50 kg para a carga máxima de levantamento de um operário.

A implantação de condições ergonomicamente favoráveis ao trabalho é extremamente vantajosa para a Construção Civil, apesar de ser de difícil mensuração, pois, ao proporcionar segurança e bem-estar ao operário, indiretamente, estar-se-á motivando o trabalhador a atingir a satisfação pessoal e com isso ganha-se no aumento da produtividade.

\subsubsection{Equipamentos de Transporte}

A escolha do sistema de transporte adequado para as diversas etapas de construção integra a racionalização do processo. A partir da quantificação dos materiais, do cronograma da obra e do anteprojeto do canteiro, com o estabelecimento dos locais de descarga, estocagem, manipulação e utilização dos materiais e componentes, escolhe-se e dimensiona-se o sistema de transporte adequado (LICHTENSTEIN, 1987).

Quanto maior a autonomia da linha de produção em relação a equipamentos para efetuar os transportes, melhor para 0 andamento $e$ planejamento da produção (FRANCO et alii, 1991b).

Na etapa de produção dos pré-moldados leves, o transporte horizontal predomina e pode ser:

- manual, ou por meio de carrinho de duas rodas ("jericas") ou carros porta palete (figura 6.1);

- empilhadeira, e

- pórtico móvel.

Para o transporte do concreto ou argamassa frescos até seu lançamento nas formas, em distâncias reduzidas e volume de concreto pequeno, a "jerica" torna-se uma opção eficiente.

1 SILVA, L.C. (2000). (USP. Escola de Engenharia de São Carlos). Comunicação pessoal. 


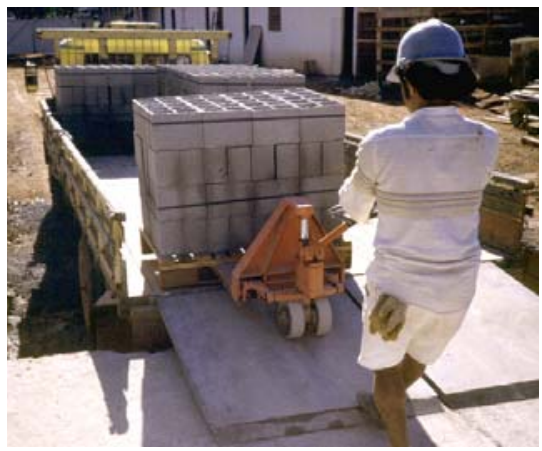

Figura 6.1: Figura de carro porta palete transportando bloco (cortesia do Eng. Marcio S. Faria)

Segundo LICHTENSTEIN (1987), "o emprego do carro porta palete para a movimentação horizontal tem seu uso restringido basicamente pela qualidade da via por onde deve transitar o carro. Em vias de má qualidade (sobre solo, por exemplo) é praticamente inviável a sua locomoção carregado".

O transporte de peças em conjunto promove a redução do manuseio de cada peça individualmente e diminui as chances de possíveis danos.

A etapa de transporte das peças pré-moldadas prontas do local de estocagem ou de produção até o local de utilização na edificação requer, em sua grande maioria, transporte vertical, o qual pode ser feito por guindastes ou elevadores. Os guindastes empregados na Construção Civil classificam-se em: móveis ou de torre (gruas).

A utilização da grua demanda que plataformas se projetem para fora do corpo da obra para introdução dos paletes no pavimento (LICHTENSTEIN, 1987).

CARRARO (1998) publicou resultados de uma pesquisa sobre tecnologia construtiva na grande São Paulo, em que se observaram os equipamentos de transporte vertical de cargas preferidos. A conclusão a que se chegou é que $67 \%$ das obras usavam somente elevador de carga, enquanto apenas $11 \%$ usavam somente grua e $22 \%$ usavam os dois tipos.

Há casos em que os pré-moldados devem ser transportados do equipamento que realizou o transporte vertical até o local de instalação; portanto, é acrescentada mais uma etapa de transporte, que pode ser feita manualmente ou por carro porta palete. 


\subsection{Fluxograma da Produção}

O fluxograma da produção, ilustrado na figura 6.2, representa as etapas que compõem a produção dos pré-moldados.

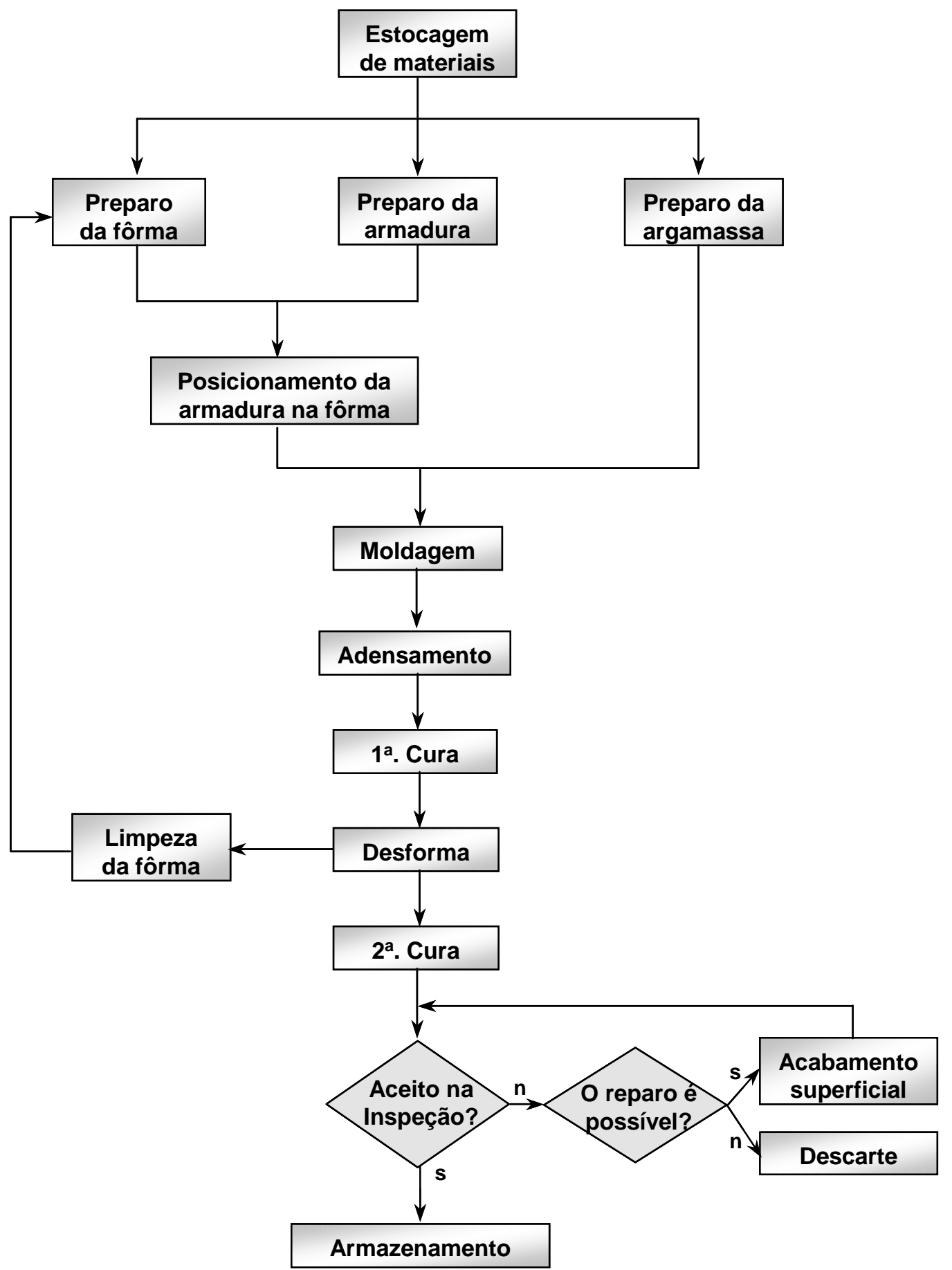

Figura 6.2: Fluxograma das atividades de produção de pré-moldados leves 


\subsection{Controle de Qualidade de Produção dos Pré-Moldados}

A indústria da Construção Civil no Brasil encontra-se em estágios de evolução da qualidade. A mentalidade dos envolvidos neste setor está mudando, impulsionada pelas exigências competitivas do mercado e exigências dos usuários. Pensar em sistemas de qualidade nos dias de hoje é uma questão de garantir a sobrevivência da empresa no mercado do futuro.

O controle de qualidade, segundo definição da ABNT (NBR ISO 8402 apud MEKBEKIAN, 1997), são técnicas e atividades operacionais usadas para atender aos requisitos para a qualidade.

A utilização de uma metodologia para o controle da qualidade de execução irá proporcionar, além da garantia de atendimento às especificações, um ganho de produtividade com a redução de perdas e de retrabalho pela equipe de produção (FERREIRA et alii, 1994).

Os procedimentos de controle utilizados devem ser definidos com base no processo construtivo e ajustados à cultura construtiva da empresa. Definem-se, assim, as especificações e tolerâncias que nortearão a execução, o controle e a aceitação do processo.

Na opinião de RODRIGUES (1989), aqui compartilhada, as indústrias de pré-moldados, por produzirem elementos fora do local definitivo de utilização, têm condições favoráveis para o estabelecimento de programas de controle de qualidade eficazes que se dividem em controle de produção e controle de aceitação, como mostra o esquema da figura 6.3.
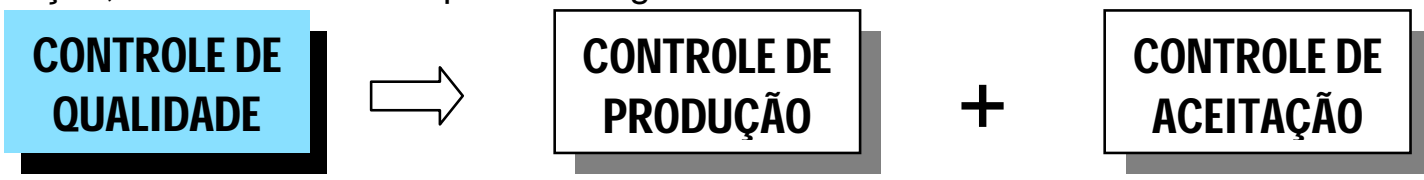

Figura 6.3: Divisão do controle de qualidade (RODRIGUES, 1989)

O controle de produção, como a própria denominação esclarece, é realizado durante o processo de fabricação da peça e o de aceitação é a última etapa do controle da qualidade feito pelo consumidor e dela depende a aceitação da peça. 
Nas indústrias de pré-moldados de concreto e argamassa armada, as maiores preocupações relativas ao controle e garantia da qualidade das peças, segundo BENTES (1993), consistem em:

- $\quad$ falhas de adensamento;

- $\quad$ bolhas nas superfícies em contato com as formas (figura 6.4);

- $\quad$ cobrimentos fora de especificações, e

- $\quad$ quebras e fissuras nas peças.

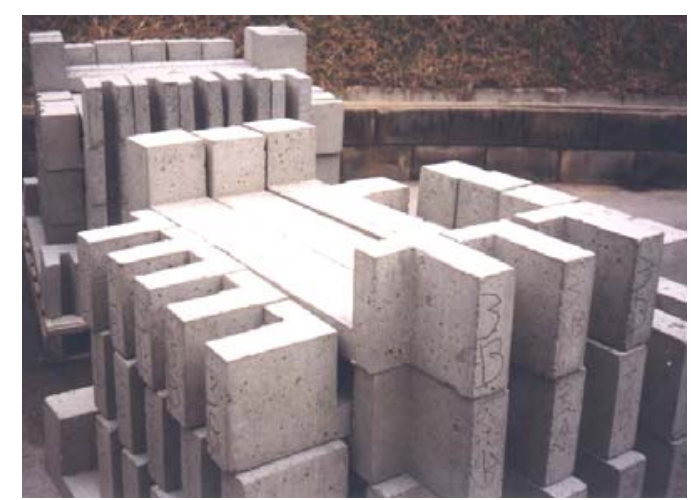

Figura 6.4: Ilustração de vergas com bolhas superficiais

Os problemas mais comuns em elementos pré-moldados, baseando-se na pesquisa de BENTES (1993), sobre pré-moldados leves, estão listados na tabela 6.2.

Tabela 6.2: Ocorrência de problemas em elementos pré-moldados leves e suas causas mais comuns (adaptada de BENTES, 1993).

\begin{tabular}{|c|c|}
\hline Problema & Causas \\
\hline $\begin{array}{l}\text { Possibilidade de falhas no adensamento da mistura, } \\
\text { como nichos de concretagem, defeitos superficiais } \\
\text { ou porosidade em níveis acima do permitido. }\end{array}$ & $\begin{array}{l}\text { Detalhes excessivos na } \\
\text { forma e preenchimento } \\
\text { inadequado }\end{array}$ \\
\hline $\begin{array}{l}\text { Formação de nichos de concretagem ou exposição } \\
\text { de armadura. }\end{array}$ & $\begin{array}{l}\text { Alta densidade (localizada) } \\
\text { de armadura }\end{array}$ \\
\hline $\begin{array}{l}\text { Perda de consistência e tempo de manutenção de } \\
\text { trabalhabilidade insuficiente. }\end{array}$ & $\begin{array}{l}\text { Traço inadequado utilizado } \\
\text { na mistura }\end{array}$ \\
\hline Aparecimento de bolhas na superfície da peça. & \multirow{2}{*}{$\begin{array}{l}\text { Tipo impróprio de } \\
\text { desmoldante }\end{array}$} \\
\hline $\begin{array}{l}\text { Avarias em regiões em contato com a forma pela } \\
\text { dificuldade da retirada da peça. }\end{array}$ & \\
\hline
\end{tabular}


FERREIRA (1991) ainda acrescenta que é comum ocorrerem vazamentos da nata de cimento, causados por abertura excessiva ou pela não utilização de elementos de vedação nas juntas das formas.

\subsubsection{Controle de Materiais}

O controle dos materiais utilizados na produção do concreto é o primeiro passo para a garantia da qualidade das peças pré-moldadas. Os insumos devem ser constantemente verificados, segundo prescrições de normas específicas.

O tema adquire grandes proporções e torna-se complexo quando se trata da avaliação dos fornecedores, do recebimento e da inspeção, do armazenamento e da qualificação: do cimento, dos agregados, da água, do aditivo e do aço, além de ensaios de garantia das propriedades da mistura fresca e endurecida.

Nesta linha de pesquisa, há trabalhos que abordam o tema com rigor: FERREIRA (1991); RODRIGUES (1989) e SOUZA \& MEKBEKIAN (1996).

\subsubsection{Controle de Formas}

As formas são estruturas provisórias cujas funções principais são conformar o concreto, proporcionar à superfície do concreto a textura requerida e suportar o concreto fresco até que ele adquira capacidade de auto-suporte.

Nenhuma superfície da peça de concreto poderá ser melhor do que a forma que Ihe deu origem; qualquer defeito será transferido com riqueza de detalhes, a ponto de ficarem mais evidentes na peça concretada do que na própria forma. 
Para chegar-se à qualidade final da peça de concreto, é preciso que as formas atendam a certos requisitos, tais como:

- resistência suficiente para suportar esforços provenientes de seu próprio peso, do peso e empuxo lateral do concreto, do adensamento e de eventuais equipamentos;

_ $\quad$ rigidez para manter as dimensões e formas previstas no projeto;

- estanqueidade para evitar perda de água e finos durante a concretagem;

- $\quad$ possibilidade do correto posicionamento da armadura;

- $\quad$ ancoragem correta de formas internas, destinadas à formação de vazios no interior dos elementos, evitando a flutuação ou o deslocamento durante a concretagem;

- $\quad$ possibilidade de desforma sem danos para o concreto;

- $\quad$ propiciação do correto lançamento e adensamento do concreto.

- textura conforme as exigências de cada projeto, especialmente nas estruturas de concreto aparente;

- $\quad$ projeto e construção visando à simplicidade, permitindo fácil desforma e reaproveitamento, e

- aderência menor possível da forma ao concreto para facilitar a desforma.

A conformação final do elemento pré-moldado ficará condicionada ao material utilizado na confecção da forma. A escolha do material depende do atendimento a requisitos: dimensões finais; tolerâncias; acabamento superficial; tipo de adensamento; tipo de cura e número de reutilizações.

Os materiais mais empregados nas formas são a madeira e o aço. A madeira é o material mais barato; porém, o custo das formas deve ser composto, considerando-se o número de reutilizações, pois a durabilidade da forma de madeira é sensivelmente inferior à da metálica, como pode ser comprovado na tabela 6.3. 
Tabela 6.3: Número de reutilizações de formas em função do tipo de material adotado (ORDOÑEZ apud EL DEBS, 2000).

\begin{tabular}{l|c}
\hline Material utilizado & $\begin{array}{c}\text { Número de } \\
\text { reutilizações }\end{array}$ \\
\hline Madeira s/ tratamento & 20 a 80 \\
\hline Madeira tratada & 30 a 120 \\
\hline Madeira revestida c/ aço & 30 a 150 \\
\hline Concreto/argamassa & 100 a 300 \\
\hline Plástico reforçados c/ fibra de vidro & 80 a 400 \\
\hline Aço (forma desmontável) & 500 a 800 \\
\hline Aço (forma não desmontável) & 800 a 1200 \\
\hline
\end{tabular}

Salienta-se, também, que as formas de madeira não podem ficar em contato com a água, nem com o vapor, situação contrária ao que é recomendado para a cura de pré-moldados. Estão sujeitas ao inchamento dos compensados de madeira e sua rápida deterioração. Uma solução para a cura de formas de madeira são sacos de aniagem úmidos, dispostos sobre a superfície exposta da peça.

Antes da liberação das formas para a concretagem, recomendam-se as verificações da tabela 6.4 .

Tabela 6.4: Requisitos das formas a serem verificados antes da liberação para concretagem.

\section{Dimensões}

Devem estar em concordância com o projeto e com as tolerâncias permitidas.

Cuidados especiais com: posição de furos, recortes e saliências.

Verificar: alinhamento, nivelamento, prumo e esquadro.

\section{Estanqueidade}

Correta montagem e fechamento das partes componentes da forma.

Vedação eficiente nas juntas.

\section{Superfícies}

Devem estar absolutamente limpas, sem apresentar incrustações de concreto, pontos de solda ou qualquer outro produto estranho à forma.

As marcas de vibrador, os buracos de prego ou outra depressão qualquer devem ser preenchidos com massa plástica e convenientemente lixadas.

$O$ revestimento da forma, quando houver, deve estar bem colado e sem ondulações.

\section{Desmoldantes}

Aplicar uma fina película na superfície da forma; remover os excessos com estopa ou pano seco. 
A rotina de verificações apresentada traz requisitos gerais que devem ser revisados conforme as especificidades de cada caso.

Um tipo de verificação utilizado no Centro de Desenvolvimento de Equipamentos Urbanos e Comunitários de São Paulo (CEDEC) para conferir a estanqueidade das formas, descrito em BENTES (1992), consiste em iluminar a parte interna da forma, verificando a existência de fachos de luz na sua parte externa, os quais denunciam as regiões com boa probabilidade de vazamento de nata.

Sugere-se que cada forma receba uma identificação a qual deve ser transferida para a peça pré-moldada, ao ser desformada. Este processo facilita a rastreabilidade de moldes defeituosos.

FRANCO et alii (1991b) recomendam utilizar espátula, limalha de ferro e estopa para a limpeza e pincel, trincha e estopa para aplicar o desmoldante.

Os desmoldantes são constituídos por substâncias oleosas tensoativas que podem causar bolhas na superfície das peças. Como a cera desmoldante não é material tensoativo, soluciona o problema das bolhas superficiais, mas segundo BENTES (1992), demanda maior tempo de limpeza.

É recomendada fazer a limpeza das formas logo após a desforma, quando a remoção dos resíduos é facilitada e em seguida, aplicar o desmoldante que protegerá contra corrosão, no caso de formas metálicas.

\subsubsection{Controle das Armaduras}

Em elementos pré-moldados, é comum encontrar dois tipos de armaduras: a ativa e a passiva. No presente trabalho, são referenciadas apenas as armaduras ativas: discreta (barras e fios) e difusa (telas); portanto, as descrições apresentadas neste item se referem somente a elas.

As armaduras pré-montadas devem ser armazenadas, manuseadas e transportadas com meios e dispositivos que garantam a sua integridade $\mathrm{e}$ mantenham a sua posição relativa, bem como o alinhamento de suas barras, 
protegendo-as contra deformações e ruptura dos vínculos de posicionamento (ABNT, 1985 - NBR 9062).

Recomenda-se o uso de bancadas para a confecção das armaduras; porém, estas apenas são viáveis para peças de pequenas dimensões, da ordem de $250 \mathrm{~cm}$.

Também pode-se optar pela montagem das armaduras diretamente na forma, que passa a ter função de gabarito, desde que este procedimento não interfira no fluxo normal da produção. Com isto, podem-se reduzir erros dos armadores.

É interessante otimizar o corte das telas, com estudos de plano de corte, o que resulta na redução das perdas.

A inspeção da armadura e da sua posição da armadura na forma, antes da liberação para a concretagem, é de fundamental importância para a garantia da qualidade dos elementos produzidos; para tanto, recomendam-se as verificações propostas:

- $\quad$ bitolas, quantidades e tipos de aço idênticos aos do projeto;

- locação de espaçadores em números e posições adequadas;

- tolerância do comprimento da armadura longitudinal de $\pm 20 \mathrm{~mm}$, e de espaçamento entre estribos de $\pm 10 \%$, em relação ao projeto;

- $\quad$ espaçamento entre barras suficiente para permitir a entrada do vibrador de imersão (caso este seja adotado);

- alças de manuseio constituídas por aços CA-25, cordoalhas de protensão ou cabos de aço;

- emendas em telas soldadas para armaduras principais, com fios de diâmetro até $8 \mathrm{~mm}$, sobrepor duas malhas e para armadura de distribuição sobrepor apenas uma malha;

- diâmetro interno da curvatura dos ganchos e estribos em concordância com as especificações da ABNT (1978), NBR 6118. Para estribos de bitola inferior a $10 \mathrm{~mm}$, o diâmetro mínimo é $3 \phi$; 
- $\quad$ verificação de deformações e torções das barras no armazenamento e na posição final nas formas, e

- $\quad$ barras isentas de impurezas (ex.: terra ou outros matérias). A oxidação é aceitável, desde que não altere o diâmetro e não existam escamações.

A espessura de cobrimento da armadura em pré-moldados de argamassa armada, situa-se, usualmente, entre $4 \mathrm{~mm}$ e $10 \mathrm{~mm}$; e são os espaçadores que garantirão esta espessura mínima. Os cantos das peças são regiões com maior tendência de deslocamento da posição da armadura, em função das amarrações e das sobreposições; portanto, os espaçadores devem ser colocados nesta região com maior atenção.

Locais de estrangulamento da seção transversal ou com armadura de diâmetros relativamente grandes ou com pequena espessura da peça exigem maior densidade de espaçadores.

Os espaçadores de plásticos são mais confiáveis, comparados aos de argamassa, para o atendimento da espessura do cobrimento especificado (HANAI 1992).

O uso de gabaritos no processo de corte e dobramento da armadura ajuda a diminuir os ajustes na forma.

\subsubsection{Adensamento}

O adensamento é o procedimento que garantirá ao concreto preencher todos os vazios da forma com objetivo de expulsar bolsões de ar retidos.

Os métodos de adensamento mais utilizados em pré-moldados são: a mesa vibratória, a vibração interna por meio de vibradores de imersão e a vibração de forma.

A vibração de forma apenas é aplicada quando as dimensões ou o peso da forma inviabilizam sua movimentação, tal como seu posicionamento sobre uma mesa vibratória (BENTES, 1992). 
Alguns problemas de falhas no adensamento e as provenientes causas são apresentadas na tabela 6.5.

Tabela 6.5: Ocorrências de problemas em peças pré-moldadas causadas por adensamento inadequado e suas causas mais comuns.

\begin{tabular}{|c|c|}
\hline Problemas & Causas mais comuns \\
\hline Bolhas superficiais & Vibração excessiva. \\
\hline Raias de areia & $\begin{array}{l}\text { Exsudação de concretos com teores elevados de água. } \\
\text { Vibração excessiva. } \\
\text { Contato prolongado do vibrador com a forma. }\end{array}$ \\
\hline Linhas de fronteira & $\begin{array}{l}\text { Durante o adensamento da camada superior o vibrador não } \\
\text { penetrou na camada inferior. }\end{array}$ \\
\hline $\begin{array}{l}\text { Nichos de } \\
\text { concretagem }\end{array}$ & Ausência de vibração. \\
\hline $\begin{array}{l}\text { Camadas de cores } \\
\text { diferentes }\end{array}$ & $\begin{array}{l}\text { Demora entre o adensamento da camada superior e o } \\
\text { lançamento da camada seguinte. }\end{array}$ \\
\hline
\end{tabular}

Alguns pesquisadores qualificaram o processo de vibração com relação ao tempo, ao posicionamento do vibrador e à quantidade de concreto, dentre as quais:

- colocar uma grande quantidade de concreto sobre a forma para, só então, acionar a vibração. O concreto adensar-se-á mais rapidamente, mesmo porque haverá maior quantidade de concreto colocado, que ajudará no seu escoamento (BENTES, 1993);

- posicionar o vibrador de imersão o mais próximo possível da forma, sem contudo tocá-la (RODRIGUES, 1989);

- $\quad$ para vibradores de imersão, distanciar as inserções em torno de 1,25 vezes o raio de ação do vibrador;

- $\quad$ duração da vibração em torno de 5 a 25 segundos;

- altura de cada camada adensada com vibrador de imersão inferior a $40 \mathrm{~cm}$. Para alturas de peças maiores, dividir de modo que seja cumprida essa determinação. Quando são empregados vibradores de forma, admite-se altura da camada até $80 \mathrm{~cm}$ (RODRIGUES, 1989);

- $\quad$ a agulha do vibrador de imersão deve atingir cerca de $15 \mathrm{~cm}$ da camada de concreto subjacente (MATTOS, 1997); 
- na última camada, lançar o concreto em excesso que, após o adensamento será removido (RODRIGUES, 1989);

- $\quad$ retirar a agulha do vibrador de imersão lentamente e com o motor ligado para não formar bolsões de ar (MATTOS, 1997);

- os equipamentos de adensamento devem estar em boas condições e com amplitude e freqüência verificadas periodicamente, e

- traços de concretos mais plásticos devem ser, preferencialmente, adensados com vibradores de alta freqüência. Para misturas mais secas, usar baixa freqüência e alta amplitude (MATTOS, 1997).

Não existe regra única e precisa estipulada para proceder o adensamento; portanto, a eficiência do processo será melhorada com a experiência adquirida e avaliações empíricas.

\subsubsection{Cura}

A etapa de cura do concreto compreende os procedimentos destinados a promover a hidratação do cimento.

Esta etapa merece especial atenção, pois os cuidados aqui dispensados definirão a qualidade da peça no que diz respeito, principalmente, à sua durabilidade.

Há várias maneiras de promover a cura, dentre elas:

- $\quad$ aspersão: as superfícies expostas são permanentemente umedecidas;

- $\quad$ imersão: mergulhar as peças em tanques de água;

- térmica: aumentar a temperatura do concreto, e

- película impermeabilizante: aplicar pinturas que impeçam a saída de água pela superfície exposta.

A escolha do tipo de cura depende de fatores como material constituinte das formas, necessidade de reutilização das formas, espaço disponível para implantação dos processos de cura, produtividade desejada pela empresa e investimento disponível. 
Em elementos pré-moldados, é comum haver a separação da cura em duas fases. A primeira cura ocorre imediatamente após o adensamento e a peça permanece na forma até adquirir resistência suficiente para a desmoldagem. A segunda cura acontece após a desmoldagem do concreto, em que a peça permanece até atingir a resistência de projeto.

EL DEBS (2000) não recomenda a desmoldagem com resistência inferior a $10 \mathrm{MPa}$, enquanto o $\mathrm{ACl}$ (1994) proíbe a desmoldagem até o concreto atingir 70\% da resistência à compressão especificada.

\section{A. Cura por Aspersão}

A cura por aspersão tem características similares à irrigação agrícola. Por intermédio de aspersores e nebulizadores, as superfícies expostas dos pré-moldados permanecem constantemente umedecidas.

Experiências realizadas pelo CEDEC e relatadas por BENTES (1992), comprovaram a eficiência deste processo. Segundo o autor, "aproximadamente 90 minutos após o preenchimento das formas, iniciava-se a aspersão da água, de maneira intermitente, mantendo, durante todo o ciclo de primeira cura, a superfície das peças totalmente úmida. Este ciclo tinha a duração aproximada de 18 a 20 horas". No dia seguinte ao da moldagem, as peças eram desformadas e encaminhadas à área onde se faria a segunda cura. A duração da segunda cura era estimada em três dias, também por aspersão.

\section{B. Cura por Imersão}

A cura por imersão é um processo simples, no qual as formas são colocadas em tanques de água limpa e isentos de produtos químicos, após um período de 60 a 90 minutos, a partir da sua moldagem (BENTES, 1992).

A empresa deve dispor de espaço suficiente para os tanques, de modo que acomodem satisfatoriamente a quantidade de peças pré-moldadas.

Dados extraídos de BENTES (1992) mencionam um período de 48 horas referentes à primeira cura para que se proceda a desforma sem quebras significativas, para a cidade de São Paulo, durante o inverno. Após a 
desmoldagem, os pré-moldados são encaminhados aos tanques de segunda cura, aí permanecendo por um período de 3 a 5 dias, quando então terão atingido resistência suficiente para serem manuseados.

FERREIRA (1991) traz indicações de um período de primeira cura de aproximadamente 12 horas. Para a segunda cura, o autor recomenda um período mínimo de 3 dias.

\section{Cura Térmica}

As formas de se proceder a cura térmica são: vapor atmosférico; autoclave; circulação de água ou óleo em tubos junto às formas e resistência elétrica.

A cura a vapor é a mais difundida entre os produtores de pré-moldados, pois alia eficácia a razoáveis investimentos financeiros.

O processo consiste em saturar o ambiente e elevar a temperatura (da ordem de 65 a $70^{\circ} \mathrm{C}$ ), com o que, as reações químicas são aceleradas ao mesmo tempo que o cimento é hidratado.

Deve haver o controle da elevação da temperatura, assim como da sua redução, segundo curvas de temperatura em função do tempo, que consideram os seguintes parâmetros, como especificado pela ABNT (1985), NBR 9062:

_ $\quad$ incremento máximo de $20^{\circ} \mathrm{C} /$ hora na elevação da temperatura;

- temperatura máxima de $70^{\circ} \mathrm{C}, \mathrm{e}$

- $\quad$ decréscimo de temperatura máximo de $30^{\circ} \mathrm{C} /$ hora.

RODRIGUES (1989) recomenda que, terminada a concretagem, a peça seja mantida em temperatura ambiente por 2 horas, no mínimo, e durante a cura térmica, a temperatura do concreto não atinja $50^{\circ} \mathrm{C}$ antes de 2 horas, a partir do adensamento. A temperatura máxima não deve ser alcançada antes de 6 horas.

$\mathrm{O} \mathrm{ACl}$ (1994) recomenda para peças curadas a temperaturas entre $52 \mathrm{e}$ $85^{\circ} \mathrm{C}$, um período de cura térmica de 12 a 72 horas. 
Uma outra versão de cura a vapor é apresentada no Manual do Processo Construtivo POLI-ENCOL (FRANCO et alii, 1991b), pelo qual as formas são envolvidas por uma lona e recebem o vapor por um gerador, a temperatura é elevada e o ar fica saturado.

\subsubsection{Análise e Inspeção da Peça Concretada}

É nesta fase do controle de qualidade que a verificação comprovará se as peças atendem aos requisitos previamente determinados. As conformidades serão analisadas por uma equipe desvinculada da produção que terá condições de alertar a equipe quanto a possíveis falhas.

Criar listas de verificações (check list) é um caminho racional para garantir eficiência na análise e inspeção das peças.

Se as peças forem aprovadas pela inspeção, são liberadas para o estoque ou para uso na obra; caso contrário, são condenadas ou direcionadas para reparos. A peça apenas será condenada, se a parte danificada comprometer o seu desempenho estrutural.

FRANCO et alii (1991b) sugerem que o tratamento superficial para eliminar defeitos como bolhas e poros seja feito com aplicação de pasta de cimento e resina látex. A argamassa com areia de granulometria fina em conjunto com adesivo à base de acrílico ou PVA (acetato de polivinila) garantirá melhor aderência entre o material antigo com o material fresco, em pequenas reconstituições de regiões quebradas da peça como cantos e arestas.

Antes de liberar a peça para a estocagem ou para o uso, é importante verificar:

- $\quad$ atendimento às condições especificadas para levantamento, manuseio e armazenamento dos elementos;

- dimensões dos elementos, insertos, recortes, saliências e respectivas tolerâncias;

- $\quad$ defeitos provocados pelas formas;

- $\quad$ falhas ou defeitos do concreto (lançamento, adensamento, etc); 
- $\quad$ presença de fissuras e armaduras expostas;

- aparência quanto a rebarbas, cantos quebrados, lascas, bolhas na superfície, homogeneidade de cor e textura da superfície, e

- tolerâncias quanto a distorções, não linearidade, flechas e contraflechas.

\subsubsection{Transporte e Armazenamento}

A formação de conjuntos de elementos pré-moldados que pode ser em forma de paletes, antes do transporte, é um procedimento recomendável, pois com a diminuição do manuseio de cada uma das peças isoladamente, as possibilidades de ocorrerem avarias se reduzem, como ilustrado na figura 6.5.

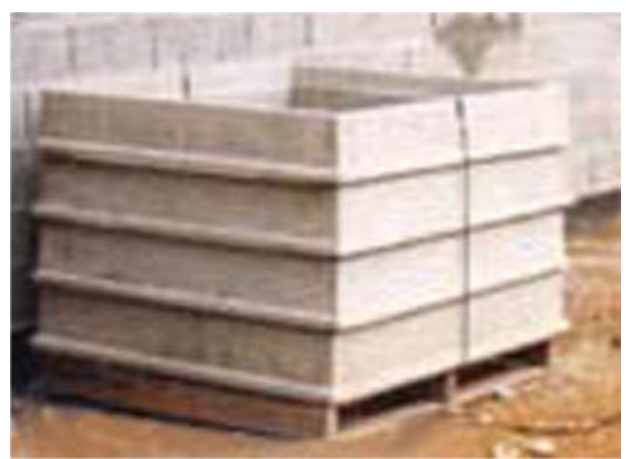

Figura 6.5: Contramarcos pré-moldados empilhados em forma de paletes

Outra recomendação quanto ao transporte, que também se aplica à estocagem, consiste em posicioná-los da maneira como serão usados definitivamente, evitando o aparecimento de esforços não previstos em projeto.

O espaço para estocagem depende da política adotada pela empresa. Se ela encaminhar toda a produção para a obra, o espaço de estoque será mínimo; caso contrário, este espaço dependerá do tamanho do elemento e da produtividade da mão-de-obra.

No caso de usar o empilhamento para estocar os pré-moldados, a estabilidade lateral da pilha deve ser verificada para se evitarem o tombamento e a conseqüente perda dos elementos. Caso haja necessidade de escoramento lateral, este não deve introduzir esforços não previstos no cálculo dos elementos. 


\subsection{Materiais Alternativos}

É comum haver certa relutância na adoção de novos materiais por parte dos construtores. Vários são os motivos da relutância contra novas tecnologias, como a falta de conhecimento sobre os benefícios, a falta de domínio da tecnologia ou o receio de investimentos sem retorno.

Este item tem como objetivo apresentar algumas soluções viáveis para adoção de materiais alternativos ou de adições que melhorem o comportamento dos pré-moldados leves sugeridos, tentando com a apresentação das características de alguns materiais apagar pré-concepções.

Os materiais e adições em destaque são as fibras de polipropileno, o agregado leve e o concreto reciclado.

\subsubsection{Fibras de Polipropileno}

A adição de fibras na matriz de concreto resulta num compósito, denominado concreto reforçado com fibras, resistente ao impacto, resistente à fadiga, tenaz, dútil e com maior deformação de tração na ruptura, comparado ao concreto comum sem adições. Além disso, a presença das fibras inibe a propagação das fissuras através da matriz (MEHTA \& MONTEIRO, 1994).

Na prática, segundo TEZUKA (1989), a máxima quantidade de fibras de polipropileno incorporada à matriz de cimento é de $1 \%$ em volume, mas mesmo com teores bem inferiores de volume de fibra, como 0,5\%, têm-se obtido concretos com considerável melhoria na resistência ao impacto.

Segundo a autora, a resistência à flexão de concreto não é essencialmente alterada pela presença de pequeno volume de fibras curtas de polipropileno. De maior importância é o seu comportamento após fissura e a sua capacidade de continuar absorvendo energia enquanto as fibras são arrancadas.

É comum encontrar nos elementos de concreto de pequena espessura ou elementos em argamassa armada uma armadura em tela com função de controlar a fissuração decorrente da retração hidráulica e das solicitações mecânicas e absorver pequenos impactos. Nestes casos, a substituição das telas 
metálicas por fibras de polipropileno é muito conveniente, pois as fibras além de ajudarem no controle de fissuração, proporcionam redução do peso e do custo do elemento.

Há dados de redução de custo de materiais em torno de 45 a 50\% pela substituição da tela de aço por fibras de polipropileno na produção de painéis divisórios (Bentes, 1992).

Em peças sem armadura, pode-se acelerar o endurecimento do concreto com uso de aditivos à base de cloreto de cálcio, procedimento não recomendado no concreto armado por provocar a corrosão da armadura.

O uso de concreto reforçado com fibras é uma prática estabelecida em muitos países como uma solução para vários problemas de engenharia. A grande potencialidade está em combinar com a armadura convencional para controlar fissuras, reduzir dano local e aumentar o desempenho sob carregamento dinâmico.

Ensaios foram realizados na Escola de Engenharia de São Carlos, segundo BENTES (1992), nas quais se verificou a boa atuação das fibras de polipropileno. No controle da fissuração da argamassa, placas armadas com fios de $4,2 \mathrm{~mm}$ e fibras submetidas à flexão apresentaram melhor desempenho do que placas armadas com tela soldada. 


\subsubsection{Concreto Leve}

O concreto leve, por conter massa específica reduzida, é capaz de produzir um elemento pré-moldado mais leve, melhorando-se o manuseio pela mão-de-obra.

Uma das formas de se obter o concreto leve é substituindo-se o agregado comum por agregado com massa específica reduzida, e é este tipo que será aqui abordado.

A revisão 2000 da NB-1 (ABNT, 1978) define concretos de massa específica normal aqueles que, depois de secos em estufa, têm massa específica compreendida entre 2000 e $2800 \mathrm{~kg} / \mathrm{m}^{3}$.

O ACl (1987) define como concretos estruturais leves aqueles cuja resistência à compressão aos 28 dias está acima de $17 \mathrm{MPa}$ e o peso específico aos 28 dias, seco ao ar, não excede $1850 \mathrm{~kg} / \mathrm{m}^{3}$.

Para ser considerado concreto leve estrutural, a norma ASTM (C 330) especifica relações entre a massa específica seca aos 28 dias, a resistência à compressão e à tração, e ainda considera que a massa específica dos agregados leves miúdos e graúdos não devem exceder no estado solto e seco, os valores de 1120 e $880 \mathrm{~kg} / \mathrm{m}^{3}$, respectivamente (MEHTA \& MONTEIRO, 1994).

Os agregados comumente utilizados são: a escória de alto forno (massa específica entre 1120 e $1360 \mathrm{~kg} / \mathrm{m}^{3}$ ); a cinza volante e a argila expandida.

No concreto leve, os agregados, por serem altamente porosos e fracos, são os limitadores da resistência e muitas vezes, quando o concreto leve é submetido à ruína, a fratura passa através das partículas dos agregados, diferentemente do que acontece com os concretos usuais, cuja zona de transição é a região mais fraca.

Como descrito acima, os concretos leves estruturais apresentam algumas características peculiares, comparadas aos concretos de massa específica comum. Algumas delas estão resumidamente apresentadas na tabela 6.6, baseadas em MEHTA \& MONTEIRO (1994) e AGNESINI \& GOMES NETO (1998). 
Tabela 6.6: Propriedades do concreto leve estrutural.

\begin{tabular}{|c|c|}
\hline 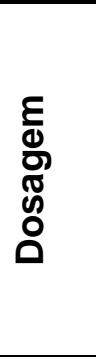 & $\begin{array}{l}\text { Os métodos de dosagem em massa são os mais indicados, no entanto, a } \\
\text { dosagem em volume absoluto pode ser utilizada, desde que se conheça a } \\
\text { absorção do agregado. } \\
\text { Em misturas de alta fluidez, há tendência do agregado leve segregar, } \\
\text { resultando na sua flutuação. Para evitar este efeito, limita-se o abatimento } \\
\text { máximo e recomenda-se a incorporação de } 5 \text { a } 7 \% \text { de ar. } \\
\text { Para a determinação de traços, recomenda-se consulta às especificações do } \\
\text { ACI } 211.2 \text {, sobre concreto leve estrutural. }\end{array}$ \\
\hline 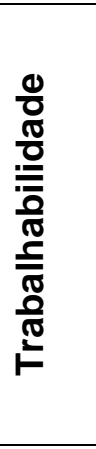 & $\begin{array}{l}\text { Para um mesmo nível de trabalhabilidade, o concreto leve exige abatimento } \\
\text { menor, comparado com o concreto normal, causado pela baixa densidade e } \\
\text { textura áspera do agregado poroso. } \\
\text { O agregado deve ser incorporado à mistura previamente saturado para evitar } \\
\text { a perda do abatimento por continuidade na absorção de água após a mistura. } \\
\text { A ordem da mistura dos materiais na betoneira pode alterar a } \\
\text { trabalhabilidade; assim, sugere-se que o agregado poroso seja adicionado } \\
\text { por último, amenizando o problema da absorção de água. } \\
\text { A substituição de parte dos agregados por areia natural melhora a } \\
\text { trabalhabilidade, diminui a demanda de água e do teor de cimento. }\end{array}$ \\
\hline 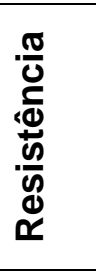 & $\begin{array}{l}\text { Quanto mais poroso for o agregado, mais vazios haverá e menor será sua } \\
\text { resistência. } \\
\text { A relação entre a resistência à tração (por compressão diametral) e à } \\
\text { compressão decresce conforme aumenta a resistência do concreto. } \\
\text { A resistência à abrasão é baixa como conseqüência direta da porosidade dos } \\
\text { agregados. }\end{array}$ \\
\hline 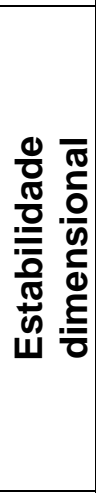 & $\begin{array}{l}\text { Dados experimentais estimam que o módulo de elasticidade é reduzido em } \\
\text { torno de } 15 \text { a } 30 \% \text { em relação ao concreto normal. } \\
\text { Como conseqüência da porosidade e maior absorção de água, os valores de } \\
\text { retração por secagem e fluência são maiores do que em concretos normais, } \\
\text { entre } 5-40 \% \text { e entre } 20-60 \% \text {, respectivamente. } \\
\text { O coeficiente de Poisson pode ser considerado igual ao do concreto } \\
\text { convencional. } \\
\text { Valores típicos: } \\
\text { Retração por secagem: } 8 \times 10^{-4} \mathrm{~cm} / \mathrm{cm} \\
\text { Fluência: } 16 \times 10^{-4} \mathrm{~cm} / \mathrm{cm} \\
\text { Módulo de Elasticidade: } 1,05 \times 10^{4} \text { a } 1,4 \times 10^{4} \mathrm{MPa}\end{array}$ \\
\hline $\begin{array}{l}\frac{0}{0} \\
\frac{\pi}{0} \\
\frac{0}{\overline{0}} \\
\frac{\pi}{\frac{\pi}{2}} \\
\frac{0}{2}\end{array}$ & $\begin{array}{l}\text { A permeabilidade é baixa, o que resulta em melhor durabilidade, em } \\
\text { conseqüência da ausência de microfissuração na zona de transição do } \\
\text { agregado com a pasta. } \\
\text { Apesar dos agregados leves serem mais porosos, esta característica não é } \\
\text { transmitida aos concretos formados por este material, pois análises } \\
\text { microscópicas comprovaram que os poros não são interconectados, } \\
\text { impedindo o fluxo de gases e líquidos. }\end{array}$ \\
\hline
\end{tabular}

A maioria das aplicações de concreto leve em todo o mundo, como afirmado por MEHTA \& MONTEIRO (1994), continua a ser na produção de elementos e painéis pré-fabricados de concreto, em virtude dos menores custos de manuseio, transporte e construção. 
CLARKE (1993) observa que há experiências desastrosas com o manuseio de elementos pré-fabricados porque o concreto com agregado leve recém curado é sensivelmente mais frágil.

No Brasil, há indícios de que o concreto com agregado leve vem sendo utilizado, de maneira restrita, por mais de três décadas.

Há o conhecimento da aplicação de concreto leve de argila expandida, em 1995, na pré-fabricação dos degraus da arquibancada do autódromo Internacional Nelson Piquet. Esta foi uma opção para se contornar o problema do peso próprio dos elementos estruturais que deveriam ser superpostos a uma estrutura metálica já existente no local (ALBUQUERQUE et alii, 1996).

Ressalta-se que estes materiais, assim como qualquer outro, apresentam desvantagens que devem ser bem analisadas; portanto, recomenda-se um estudo mais detalhado sobre as características do concreto a ser empregado.

\subsubsection{Concreto Reciclado}

"A reciclagem pode ser entendida como o reaproveitamento dos produtos ou materiais que resultaram de algum processo produtivo, tornando-os novamente úteis, podendo-se manter ou não as mesmas características do material de origem" (LATTERZA, 1998).

O setor da Construção Civil apresenta grande potencialidade de aproveitar os resíduos provenientes da reciclagem e sob a ótica de JOHN (1996), este já é o principal setor da economia a reciclar resíduos.

O resíduo da construção e da demolição é popularmente denominado entulho.

Há viabilidade do aproveitamento do entulho reciclado em diversos serviços nas edificações e em infra-estrutura urbana, como: agregado miúdo e graúdo para concretos não estruturais e para pré-moldados leves, tais como os blocos de vedação e de pavimentação para tráfego leve; argamassa de revestimento; agregado ensacado para contenção de taludes e canalização de córregos, e leitos de vias públicas e estradas. 
A reciclagem do entulho pode ser realizada em sistemas descentralizados, ou seja, usinas de reciclagem, ou no canteiro da obra. No canteiro, o equipamento necessário é de médio porte, conhecido como moinho. Geralmente, são empregados os moinhos de rolo que são equipamentos simples, cuja função é moer os agregados e misturar as argamassas, como ilustrado na figura 6.6.

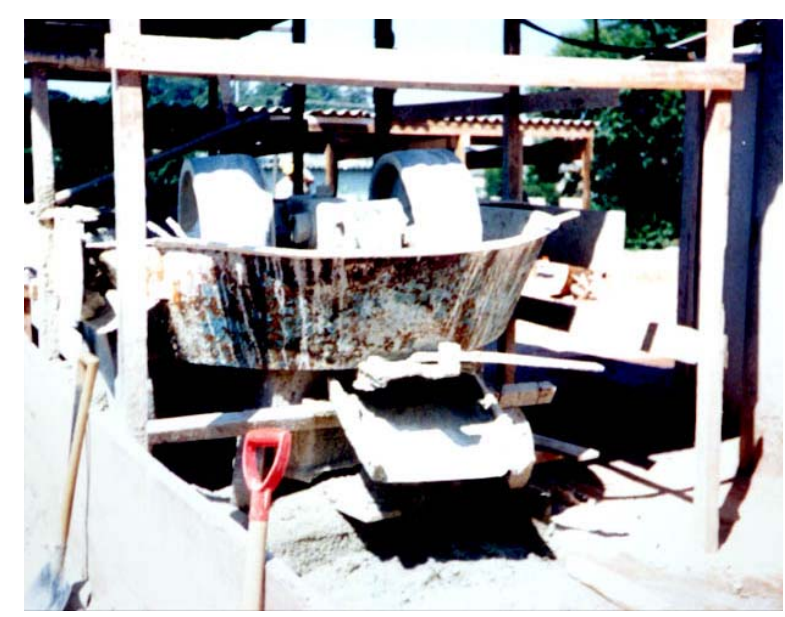

Figura 6.6: Moinho de reciclagem de resíduos no canteiro da obra

A reciclagem de canteiro traz como benefícios a economia com o transporte dos resíduos, "bota-fora", até os locais de aterro, e a possibilidade de haver controle sobre a qualidade do resíduo.

Para o uso do material reciclado como agregado, é importante determinar suas características físicas, tais como, granulometria, massa específica e massa unitária; escolher o traço e verificar a resistência dos concretos ou argamassas, respeitando-se as especificações das normas brasileiras.

LATTERZA (1998), em seus estudos, propôs um modelo de painel leve pré-moldado para construção de habitações populares, utilizando agregado graúdo reciclado, proveniente de usinas de reciclagem de Ribeirão Preto e concluiu ser viável técnica e economicamente a utilização do agregado reciclado, para o preparo de concretos.

Neste mesmo estudo, foi observada a necessidade de acrescentar-se mais água à mistura durante o preparo do concreto, causada pelo índice de vazios do agregado reciclado ser quase três vezes superior ao do agregado natural. 
A absorção e o índice de vazios influem significativamente na trabalhabilidade do concreto preparado com agregado reciclado, pelo aumento da velocidade de perda do abatimento. Em análise dos resultados dos estudos de LATTERZA (1998), pode-se considerar que um concreto permaneça com boa trabalhabilidade durante apenas 60 minutos. "Por outro lado, este fenômeno diminui a água livre da mistura, conferindo com isto um aumento na resistência à compressão, contribuindo ainda para uma "cura interna" do concreto".

$\mathrm{Na}$ ausência de dados experimentais mais apurados, as características do concreto com agregados graúdos reciclados (com $\phi \geq 4 \mathrm{~mm}$ ), podem ser obtidas com a multiplicação dos coeficientes apresentados na tabela 6.7.

Tabela 6.7: Coeficientes de ralação recomendados pelo Rilem¹ ${ }^{1}$ LATTERZA, 1998).

\begin{tabular}{|l|c|c|c|}
\hline \multicolumn{1}{|c|}{ Valores de projeto } & Tipo I & Tipo II & Tipo III \\
\hline Resistência à tração & 1 & 1 & 1 \\
\hline Módulo de elasticidade & 0,65 & 0,8 & 1 \\
\hline Coeficiente de fluência & 1 & 1 & 1 \\
\hline Retração & 2 & 1,5 & 1 \\
\hline
\end{tabular}

Tipo I: agregados reciclados originários principalmente de pedaços de alvenaria; Tipo II: agregados reciclados originários principalmente de pedaços de concreto; Tipo III: agregados que se compõem da mistura de agregados reciclados e naturais.

$$
\text { Em estudos realizados por LEVY \& HELENE (1996), utilizando }
$$
equipamentos de pequeno porte para produção de argamassas para revestimentos no canteiro, foi constatada uma economia em média de $30 \%$ no consumo de cimento comparado às argamassas convencionais.

Analisando-se as informações apresentadas sobre concreto com agregado reciclado, pode-se concluir que a reciclagem é uma opção para a produção dos pré-moldados leves.

No entanto, antes da adoção do agregado reciclado, recomenda-se avaliar o entulho gerado, conforme a fase da obra e se a quantidade de entulho será suficiente para o desenvolvimento da tecnologia.

\footnotetext{
${ }^{1}$ Réuniom International des Laboratoires d'Essais et Matériaux
} 


\section{CONCLUSÃO}

Este trabalho atendeu ao objetivo proposto de pesquisa dos mais importantes tipos de pré-moldados leves utilizados em edifícios de alvenaria estrutural, visando-se à racionalização do processo construtivo, com a otimização do uso de recursos; à melhoria da qualidade; da produtividade e à redução de custos.

Foram analisados aspectos relacionados à coordenação modular, com a aplicação de seus conceitos na modulação da alvenaria; à análise estrutural, com a apresentação de modelos de dimensionamento e exemplos; e à produção dos pré-moldados.

Os pré-moldados leves analisados, conforme proposto, foram os blocos, apenas em seu aspecto modular; as escadas, as vergas, os contramarcos, as pingadeiras e as peças de ajuste dimensional que englobam "rapaduras", réguas de ajuste, caixa suporte para aparelhos de ar condicionado e elementos modulares vazados.

Nos edifícios em alvenaria estrutural, os pré-moldados leves trazem benefícios associando-se a particularidades deste processo, tais como: rapidez de execução, rígido controle de qualidade, coordenação modular, ações organizacionais, padronização e melhor detalhamento de projeto.

Em linhas gerais, os pré-moldados estudados têm características como:

- $\quad$ simplificação das atividades de execução, reduzindo-se o número de operações;

- $\quad$ desenvolvimento de atividades sem interrupções; 
- $\quad$ construção de acessos definitivos e garantia de adequação aos espaços de trabalho;

- $\quad$ minimização das interferências entre a atividade executada e as demais atividades ligadas a ela, e

- $\quad$ padronização das tarefas para um mesmo processo.

No capítulo 3, foram aplicados, na alvenaria estrutural, os conceitos apresentados da coordenação modular, discutindo-se e exemplificando-se pontos específicos desse processo construtivo, como a amarração entre paredes.

A coordenação modular assume papel imprescindível na elaboração do projeto em alvenaria estrutural, com conseqüências futuras na fase de execução da obra, com: a diminuição de problemas de interface entre componentes e subsistemas; a padronização dos componentes e das técnicas executivas; a simplificação da execução da obra e a redução das perdas de materiais.

Como pôde ser observado no terceiro capítulo, para o acerto na modulação, são utilizados blocos com dimensões "especiais", não normalizados pela ABNT, e que são bem aceitos pelos construtores, como é o caso dos blocos múltiplos de $15 \mathrm{~cm}$, blocos de 35 e $45 \mathrm{~cm}$ de comprimento modular. Portanto, é necessário revisar as especificações da ABNT.

As juntas associadas aos blocos delimitam o espaço modular e a sua espessura, recomendada em $1 \mathrm{~cm}$ pela ABNT (1985), NBR 9062, atende aos requisitos dimensionais da modulação e estruturais; portanto, o controle de execução é importante para o perfeito funcionamento do sistema. Neste trabalho, foram citadas algumas ferramentas que auxiliam o preenchimento das juntas, como a bisnaga, a meia-cana e a palheta.

Muitas vezes, nos projetos, não são especificados os ajustes na alvenaria, resultando em improvisos na etapa de execução da obra o que leva às perdas; portanto, é importante atentar sempre para as interfaces dos componentes e para a verificação da existência de eventuais ajustes.

A importância da modulação altimétrica é haver coordenação dimensional entre os demais componentes e subsistemas. As regiões de interface 
com as paredes são críticas, por possíveis interferências, como acontece, principalmente, com as lajes e as esquadrias.

Prever meios de compatibilizar os subsistemas em concordância com a modulação da alvenaria evita o corte dos componentes e reduz os ajustes.

Os pré-moldados destinados para uso em edifícios de alvenaria estrutural devem ter suas dimensões coordenadas com a modulação da alvenaria. Este fato pôde ser comprovado durante o desenvolvimento do trabalho, em que se procurou demonstrar as dimensões em função do módulo a ser adotado.

Conforme apresentado no capítulo 4, as escadas pré-moldadas minimizam as dificuldades provenientes da moldagem das escadas no local. Elas permitem a execução de acessos definitivos aos espaços de trabalho, com a obra ainda na fase de construção, facilitando o transporte vertical de materiais e a movimentação de pessoas.

A escada jacaré, em particular, apresenta afinidade com a alvenaria estrutural, pois é constituída por elementos pré-moldados leves que chegam no local de execução prontos para a montagem, além das paredes serem portantes e capazes de suportarem as cargas provenientes do chumbamento das peças pré-moldadas.

A concepção das peças dessa escada é simples, mas exige rigores de detalhes e compatibilidade com os demais subsistemas. O dimensionamento e o detalhamento não apresentam complicações; porém, devem ser feitas as considerações das situações transitórias, em que é freqüente ocorrerem solicitações diferentes das da situação final, como foi demonstrado no exemplo do item 4.2.4.

$\mathrm{Na}$ fase de produção das peças, recomenda-se fazer o controle de execução, principalmente das dimensões, do cobrimento especificado da armadura e do acabamento final.

O número elevado de aberturas existente em uma edificação e as interferências que elas causam no processo de execução da alvenaria justificam o estudo sobre coordenação dimensional entre as esquadrias e a alvenaria. 
No capítulo 5, procurou-se apresentar as várias soluções para minimizar as interferências entre as esquadrias e a alvenaria, visando aumentar o nível de racionalização do processo. Entre as soluções apresentadas estão o uso de vergas, contramarcos, pingadeiras e caixilhos pré-moldados, e peças de ajuste dimensional, de modo que não ocorram quebras dos componentes já existentes e que sejam eliminados os enchimentos improvisados.

Além dos elementos pré-moldados, são mostradas outras soluções possíveis para a coordenação dimensional entre esquadrias e alvenaria. Foram descritos procedimentos de instalação de portas e janelas, compatíveis com o vão da abertura, tendo-se como referência as dimensões usualmente empregadas em edifícios habitacionais.

Para a escolha da melhor solução a ser adotada, foram desenvolvidos quadros comparativos (tabelas 5.2 e 5.3) de vantagens e desvantagens dos diversos procedimentos executivos apresentados.

A grande vantagem da aplicação dos pré-moldados em aberturas na alvenaria está em fixá-los conjuntamente com sua elevação, com uso da técnica de assentamento de blocos e sem necessidade de mão-de-obra especializada, resultando na terminalidade do serviço e eliminando o preenchimento posterior de ajustes.

As vergas pré-moldadas apresentam o benefício de não quebrarem o ritmo da produção na elevação da alvenaria e possibilitam que o ajuste dimensional seja incorporado na sua geometria.

O dimensionamento apresentado resultou em armaduras mínimas de fácil execução. Assim foi possível adotar detalhamento padrão das armaduras para os diversos vãos, como demonstrado no exemplo do item 5.3. No entanto, ressalta-se que, para outras condições de carregamentos, esta armadura poderá ser alterada, o que não impede de seguir o exemplo do dimensionamento apresentado para calcular com facilidade a armadura necessária.

Como o enfoque do capítulo 5 estava voltado para as aberturas na alvenaria, foi feita uma simulação teórica com modelagem numérica em elementos 
finitos do comportamento de aberturas (portas e janelas) com objetivo de analisar o fluxo de tensões em painéis isolados de parede.

Para a simulação, foram coletados dados usuais de aberturas de edificações habitacionais em alvenaria estrutural e pesquisadas as propriedades dos materiais para uma simulação simples e eficaz.

Conclui-se, com a análise dos resultados, que é necessária a presença de vergas e contravergas em janelas e vergas em portas, para evitar o surgimento de fissuras junto às aberturas. Para absorver as tensões concentradas dos cantos, as vergas devem estender-se além do vão da abertura. Recomenda-se utilizar pelo menos um bloco de cada lado do vão para que seja aproveitada a modulação. Esse comprimento supera os valores teoricamente necessários.

É importante o grauteamento vertical da parede na região adjacente à abertura em janelas. Ele apresenta aproveitamento máximo entre a verga e a contraverga.

Os contramarcos pré-moldados eliminam os requadros junto aos vãos das aberturas e permitem que as janelas sejam fixadas posteriormente à execução dos revestimentos, evitando, com isso, que sejam danificadas. Por estarem envolventes à janela, servem como referência para a execução do revestimento externo da edificação, facilitando este serviço; e se devidamente marcados, servem também como gabarito para a execução da alvenaria, como foi exposto no capítulo 5. Quando escorados, transformam-se em apoio para o assentamento dos blocos constituintes das vergas.

É possível melhorar a estanqueidade da janela, adotando-se contramarcos, a cuja geometria incorporam-se detalhes de pingadeiras, frisos, rebaixos, inclinações e saliências. Na figura 5.37, foi apresentada uma sugestão de geometria em que podem ser identificados rebaixos, saliências e inclinações. Este exemplo foi concebido analisando-se a necessidade de estanqueidade, a facilidade de produção da seção da peça e a simplicidade de instalação da esquadria. Nessa geometria, ainda podem ser acrescidos frisos e pingadeiras, contando-se com formas mais elaboradas. 
Para o sucesso na implantação dos contramarcos pré-moldados, a variação das dimensões dos vãos das janelas da edificação deve ser mínima, de modo que possa haver uma padronização das formas.

As caixas suporte de aparelhos de ar condicionado pré-moldadas com dimensões compatíveis com a modulação da alvenaria eliminam os enchimentos. Para atingir esta situação, há dois caminhos: encomendar as peças pré-moldadas para os fabricantes com as dimensões desejadas; ou fabricar no próprio canteiro, que se torna uma solução interessante, pois as caixas pré-moldadas requerem uma produção simples, decorrente de uma geometria regular e sem recortes.

Os elementos vazados modulares, apesar de serem pré-moldados leves sem função estrutural, proporcionam a elaboração de fachadas com arquiteturas mais elaboradas, dentro de um sistema modular compatível com o da alvenaria.

Peças compensadoras de ajuste tentam substituir os enchimentos quando estes são inevitáveis, decorrentes da impossibilidade de se adotarem procedimentos executivos ou componentes compatíveis com a modulação da alvenaria. Como exemplo, há a rapadura, atualmente industrializada por fabricantes de blocos e a régua de ajuste que pode ser facilmente produzida no canteiro.

O capítulo 6 trata da produção dos pré-moldados, contendo informações baseadas em trabalhos específicos sobre os temas abordados. O objetivo desse capítulo foi direcionar uma correta produção dos pré-moldados, pois como foi citado neste mesmo trabalho, uma produção mal executada pode pôr a perder todo um projeto bem elaborado.

Uma das diretrizes de racionalização das técnicas executivas em alvenaria estrutural é proporcionar condições adequadas ao transporte e ao manuseio pela mão-de-obra. Portanto, a apresentação de valores limites da capacidade portante do ser humano é imprescindível; já que foram propostos elementos para manuseio sem equipamentos especiais de içamento. A partir de várias referências de valores de peso máximo, estipulou-se o valor de $50 \mathrm{~kg}$ por operário.

Inserido no contexto da produção dos pré-moldados, conclui-se que é viável e importante o controle da produção, mesmo que esta ocorra no canteiro de 
obra. O controle pode ser padronizado, a partir da elaboração de lista de verificação. Ele é simples e traz resultados na melhoria da qualidade das peças acabadas e no ganho de produtividade com redução de perdas e de retrabalhos.

Ressalta-se que as indicações do controle da produção apresentadas são estritamente voltadas à produção de pré-moldados leves que, por serem produzidos fora do local definitivo de utilização, apresentam condições favoráveis a um controle eficaz.

Em relação aos materiais alternativos e adições, conclui-se que é viável a utilização de fibras de polipropileno, pois aumentam a resistência ao impacto e ajudam o controle da fissuração na retração hidráulica; de concreto leve, pois apresentam massa específica reduzida, que resulta em um elemento de menor peso; e de concreto reciclado, que utiliza o entulho da construção para a produção de concretos não estruturais.

Os pré-moldados leves aplicados em edifícios de alvenaria estrutural são instrumentos para implementar o nível de racionalização desse processo construtivo e com isso, elevar a produtividade e reduzir desperdícios e custos; no entanto, apenas a adoção destes elementos não traduz um bom nível de racionalização de uma empresa. O conjunto de medidas adotadas no processo todo, por sua vez, traduz a racionalização, pois torna-se possível analisar a otimização de recursos humanos, materiais, organizacionais, tecnológicos e financeiros.

Em resumo, a contribuição pretendida no presente trabalho consiste em apresentar aos construtores a viabilidade de utilização de pré-moldados em edifícios de alvenaria estrutural. Para isso, foram trazidas informações referentes à concepção do projeto, à produção dos elementos e à sua execução na construção, ressaltando-se as possíveis interferências com outros subsistemas. 
As perspectivas para estudos futuros são:

- possibilidade de uso de pré-moldados em subsistemas hidráulicos e elétricos, como por exemplo em shafts e quadros de distribuição;

- modelagem numérica mais complexa, considerando-se a não-linearidade física do material e micro-modelagem com a separação dos materiais em bloco e argamassa;

- $\quad$ pesquisas do comportamento do poliuretano (durabilidade) utilizado nas instalações de janelas;

- estudo sobre instalação de esquadrias nos processos construtivos tradicionais. 


\section{ANEXO A}

\section{FICHA DE PROCEDIMENTO EXECUTIVO}

As fichas de procedimentos executivos têm como objetivo documentar os procedimentos de execução dos serviços, resultando na padronização, e garantindo, desta forma, que sejam realizados de acordo com as diretrizes da empresa. As fichas devem estar dispostas em locais de fácil acesso a todos envolvidos no processo.

Os procedimentos devem ser sucintos e objetivos. Seu desenvolvimento deve estar voltado à aplicação prática, e em conformidade com as normas brasileiras ou com a bibliografia pertinente ao assunto.

As fichas de procedimento executivo, apresentadas neste anexo, são referentes ao serviço de marcação e furação da alvenaria para a montagem e a fixação dos pré-moldados da escada jacaré, e constituem-se um exemplo para a elaboração de fichas dos demais serviços. Elas foram desenvolvidas baseadas em SOUZA \& MEKBEKIAN (1996). 


\begin{tabular}{|l|c|}
\hline $\begin{array}{l}\text { PES - PROCEDIMENTO DE EXECUÇÃO DE } \\
\text { SERVIÇOS }\end{array}$ & PRODUÇÃO \\
\hline PROJETO: MODELO & FOLHA: \\
\hline Edifício em Alvenaria Estrutural & \\
\hline
\end{tabular}

\begin{tabular}{|c|c|}
\hline $\begin{array}{l}\text { ETAPA: } \\
\text { Execução da Escada Pré- } \\
\text { moldada Jacaré }\end{array}$ & $\begin{array}{l}\text { SUB ETAPA: } \\
\text { Execução da Montagem das Peças } \\
\text { Pré-moldadas da Escada Jacaré. }\end{array}$ \\
\hline $\begin{array}{l}\text { SERVIÇo: } \\
\text { Marcação e Furação da Alvenaria; } \\
\text { Fixação dos Pré-moldados da } \\
\text { Escada Jacaré. }\end{array}$ & $\begin{array}{l}\text { EQUIPE: } \\
\text { A ser definida pelo responsável - } \\
\text { mínimo dois operários. }\end{array}$ \\
\hline \multicolumn{2}{|c|}{$\begin{array}{l}\text { DOCUMENTOS DE REFERÊNCIA: } \\
\text { Planta do Pavimento (planta baixa e cortes); } \\
\text { Planta com o Projeto das Peças da Escada. }\end{array}$} \\
\hline \multicolumn{2}{|l|}{$\begin{array}{l}\text { FERRAMENTAS BÁSICAS: } \\
\text { - Furadeira; } \\
\text { - Bisnaga para argamassa; } \\
\text { - Nível de bolha }\end{array}$} \\
\hline $\begin{array}{l}\text { PROCEDIMENTO DE EXECUÇÃo } \\
\text { 1. Marcar os pontos da parede ond } \\
\text { 2. Furar os blocos, previamente g } \\
\text { 3. Fixar a viga jacaré e as peças } \\
\text { 4. Assentar os degraus nos o } \\
\text { assentamento; } \\
\text { 5. Assentar as peças complementar } \\
\text { 6. Posicionar os patamares; } \\
\text { 7. Solidarizar os patamares com g }\end{array}$ & $\begin{array}{l}\text { e serão furados os blocos; } \\
\text { rauteados, com brocas de vídea; } \\
\text { de apoio na alvenaria; } \\
\text { entes da viga, com argamassa de } \\
\text { es de ajuste; } \\
\text { raute. }\end{array}$ \\
\hline $\begin{array}{l}\text { RECOMENDAÇõES } \\
\text { 1. O processo de marcação deve } \\
\text { pavimento; } \\
\text { 2. A fixação do conector deverá s } \\
\text { 3. Respeitar folga de } 5 \mathrm{~mm} \text { no } \\
\text { apoio; } \\
\text { 4. Caso haja quebra nas peças } \\
\text { própria argamassa de assentame }\end{array}$ & $\begin{array}{l}\text { ser iniciado pela laje superior do } \\
\text { guir as recomendações do fabricante; } \\
\text { humbamento dos degraus e peças de } \\
\text { pré-moldadas, regulariza-las com a } \\
\text { to; }\end{array}$ \\
\hline
\end{tabular}




\begin{tabular}{|l|c|}
\hline $\begin{array}{l}\text { PES - PROCEDIMENTO DE EXECUÇÃO DE } \\
\text { SERVIÇOS }\end{array}$ & PRODUÇÃO \\
\hline PROJETO: MODELO & FOLHA: \\
\hline Edifício em Alvenaria Estrutural \\
\hline
\end{tabular}

ETAPA: Execução da Escada Prémoldada Jacaré
SUB ETAPA: Execução da Montagem das Peças Pré-moldadas da Escada Jacaré.

SERVIÇo:Marcação e Furação da
Alvenaria;
$\begin{aligned} & \text { Fixação dos Pré-moldados da } \\ & \text { Escada. }\end{aligned}$

\section{DOCUMENTOS DE REFERÊNCIA:}

Planta do Pavimento (planta baixa e cortes);

Planta com o Projeto das Peças da Escada.

\section{PROCEDIMENTO DE EXECUÇÃO}

As figuras a seguir mostram o encontro entre as lajes e a escada e a locação da viga jacaré em uma das paredes.

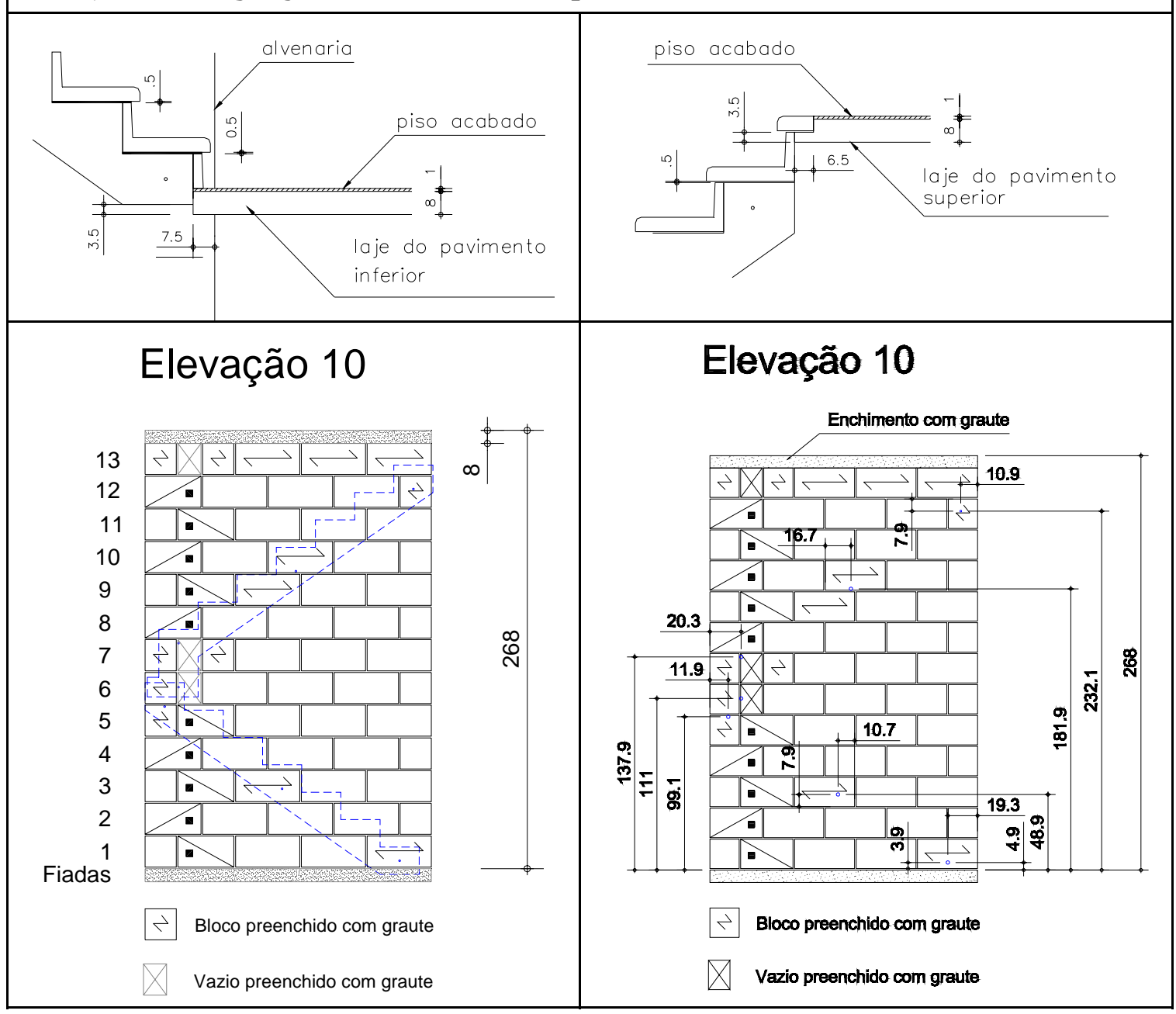




\section{ANEXO B}

\section{RESULTADO DA MODELAGEM NUMÉRICA}

O resultado do processamento da modelagem em elementos finitos para janelas com dimensões $120 \times 120 \mathrm{~cm}$ e $100 \mathrm{~cm}$ de peitoril, e janelas de mesmas dimensões com elementos enrijecidos representando as vergas e contravergas, está esquematizado em figuras que mostram o fluxo de tensões e as deformações (figuras B.1 a B.7):

- tensões no plano vertical $\left(\sigma_{y}\right)$

- tensões no plano horizontal $\left(\sigma_{x}\right)$;

- tensões de cisalhamento $\left(\tau_{x y}\right)$;

- deformações no plano horizontal $\left(\varepsilon_{y}\right)$, e

- tensões principais $\left(\sigma_{1}\right)$. 


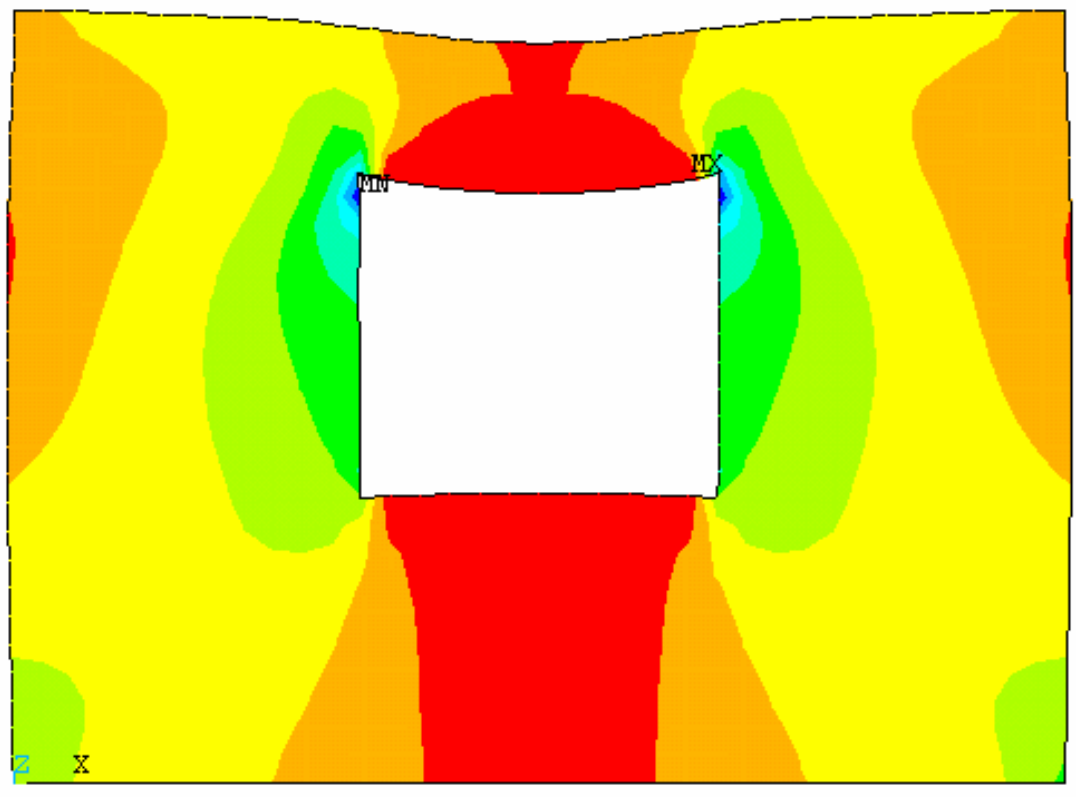

ANSYS 5.5.1SP

DEC 132000

$16: 47: 17$

NODAL SOLUTION

STEP $=2$

SUB $=1$

TIME $=2$

EPTOY

(AVG)

RSYS $=0$

PowerGraphics EFACET $=1$

AVRES=lMat

$\mathrm{DMX}=.051224$

SMN $=-.324 \mathrm{E}-03$

SMX $=.564 \mathrm{E}-0.5$

$-.324 \mathrm{E}-03$

$-.287 \mathrm{E}-03$

$-.251 \mathrm{E}-03$

$-.214 \mathrm{E}-03$

$-.178 \mathrm{E}-03$

$-.141 \mathrm{E}-03$

$-.104 \mathrm{E}-03$

$-.676 \mathrm{E}-04$

$-.310 \mathrm{E}-04$

$.564 \mathrm{E}-0.5$

Figura B 1: Deformação $\varepsilon_{y}$ para J120x120x100 (kN/cm²)

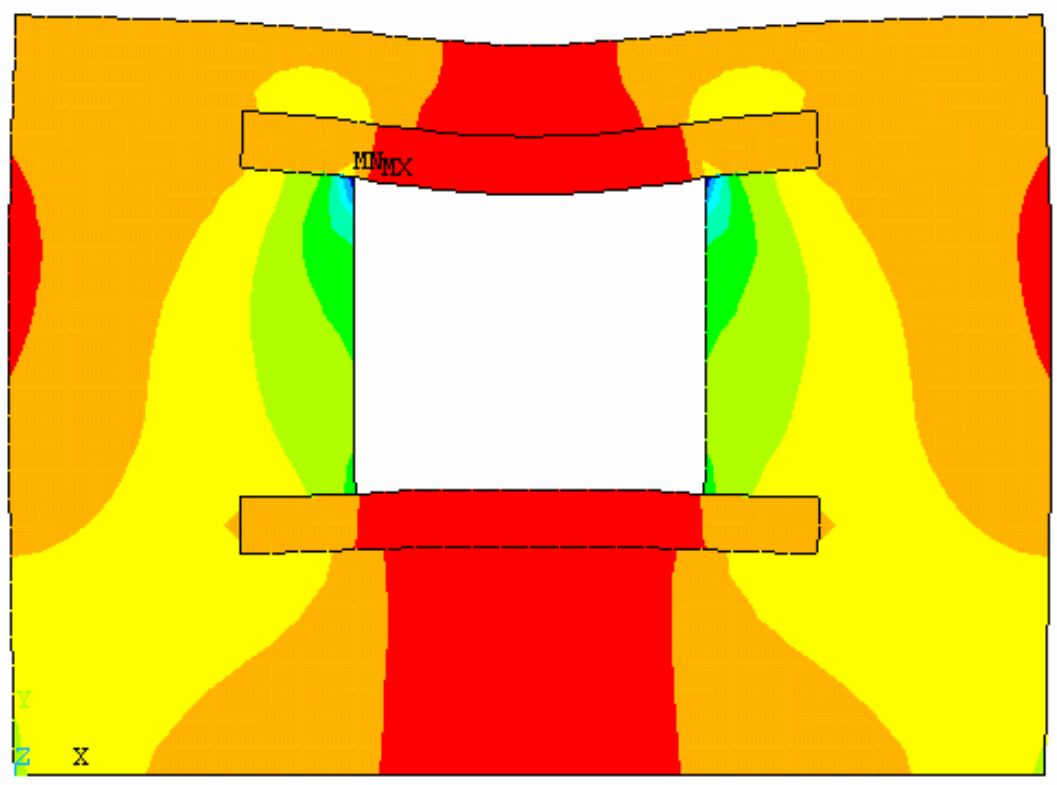

ANSYS 5.5.15P

JAN 92001

$19: 38: 28$

NODAL SOLUTION

STEP $=1$

SUB $=1$

TIME $=1$

EPTOY (AVG)

RSYS $=0$

PowerGraphics

EFACET $=1$

AVRES=Mat

$\mathrm{DMX}=.045728$

$\mathrm{SMN}=-.376 \mathrm{E}-03$

SMX $=-.226 \mathrm{E}-05$

$-.376 \mathrm{E}-03$

$-.335 \mathrm{E}-03$

$-.293 \mathrm{E}-03$

$-.252 \mathrm{E}-03$

$-.210 \mathrm{E}-03$

$-.168 \mathrm{E}-03$

$-.127 \mathrm{E}-03$

$-.854 \mathrm{E}-04$

$-.438 \mathrm{E}-04$

$-.226 \mathrm{E}-05$

Figura B 2: Deformação $\varepsilon_{y}$ para JE120x120x100 (kN/cm²) 


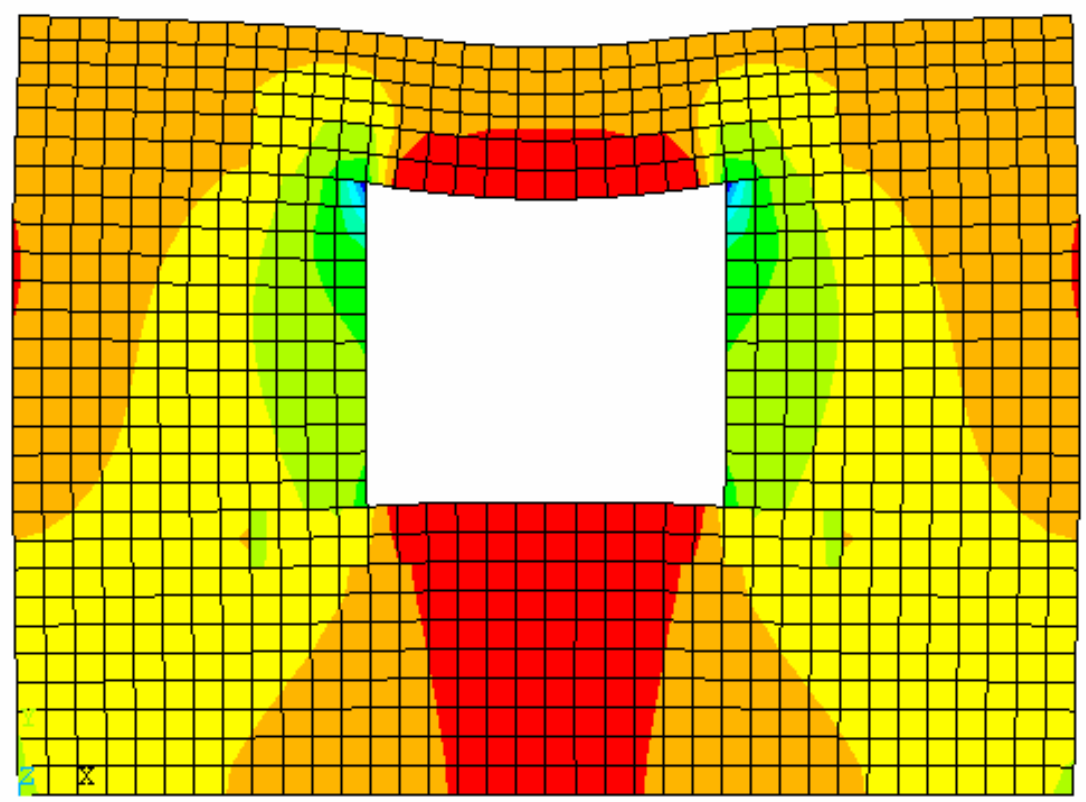

Figura B 3: Tensões $\sigma_{y}$ para JE120×120x100 $\left(\mathrm{kN} / \mathrm{cm}^{2}\right)$

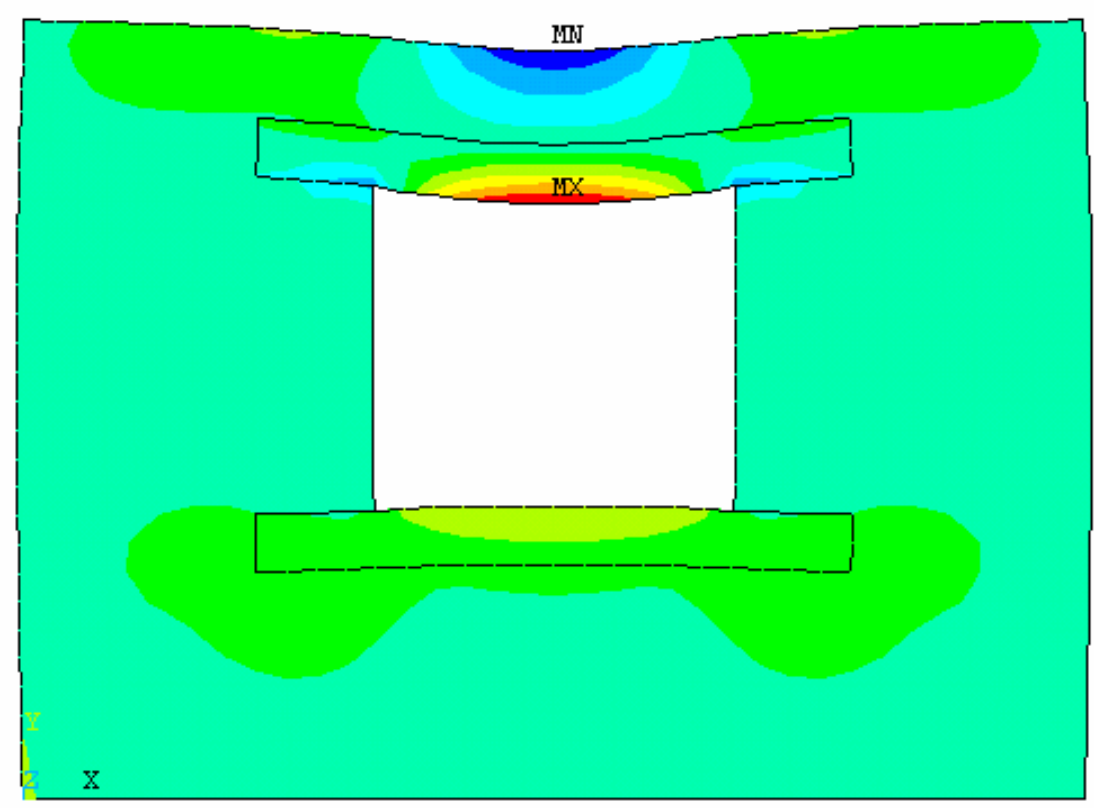

Figura B 4: Tensões $\sigma_{x}$ para JE120×120×100 $\left(\mathrm{kN} / \mathrm{cm}^{2}\right)$
ANSYS 5.5.1SP

JAN 102001

$17: 06: 55$

NODAL SOLUTION SUB $=1$

TIME $=1$

SY

(AVG)

RSYS $=0$

PowerGraphics

EFACET $=1$

AVRES=Mat

$\mathrm{DMX}=.045728$

SMN $=-.144633$

SMX $=.004471$

$-.144633$

$-.128066$

$-.111499$

$-.094932$

$-.078365$

$-.061798$

$-.04523$

$-.028663$

$-.012096$

.004471

ANSY 5.5.15P

JAN 92001

$19: 34: 56$

NODAL SOLUTION STEP $=1$

SUB $=1$

TIME $=1$

$\mathrm{SX}$

(AVG)

RSYS $=0$

PowerGraphics EFACET $=1$

AVRES=Mat

$\mathrm{DMX}=.045728$

SMN $=-.072916$

$\operatorname{sMX}=.093964$

$-.072916$

$-.054374$

$-.035832$

$-.017289$

.001253

.019795

.038338

.05688

.075422

.093964 


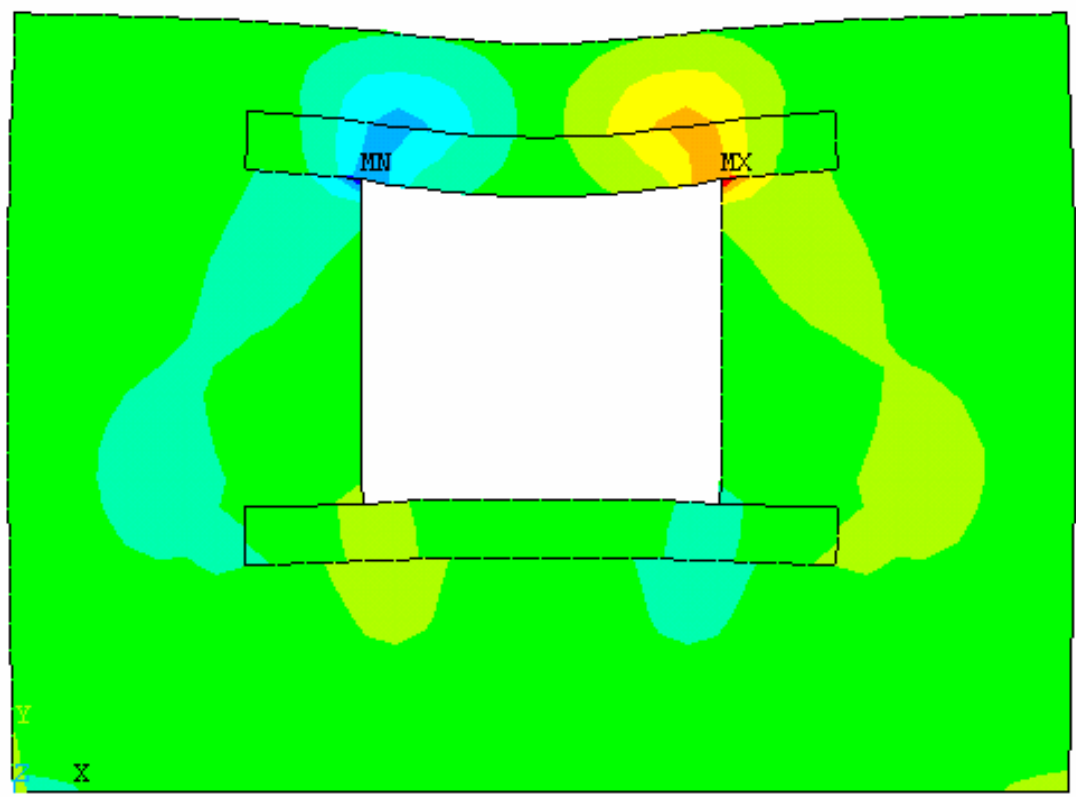

ANSYS 5.5.1SP

JAN 92001

$19: 36: 50$

NODAL SOLUTION

STEP $=1$

SUB $=1$

TIME $=1$

SXY

(AVG)

RSYS $=0$

PowerGraphics

EFACET $=1$

AVRES $=$ Mat

$\mathrm{DMX}=.045728$

SMN $=-.046717$

$\operatorname{sMX}=.046717$

$-.046717$

$-.036336$

$-.025954$

$-.015572$

$-.005191$

.005191

.015572

.025954

.036336

.046717

Figura B 5: Tensões $\tau$ xy para JE120x120x100 (kN/cm2)
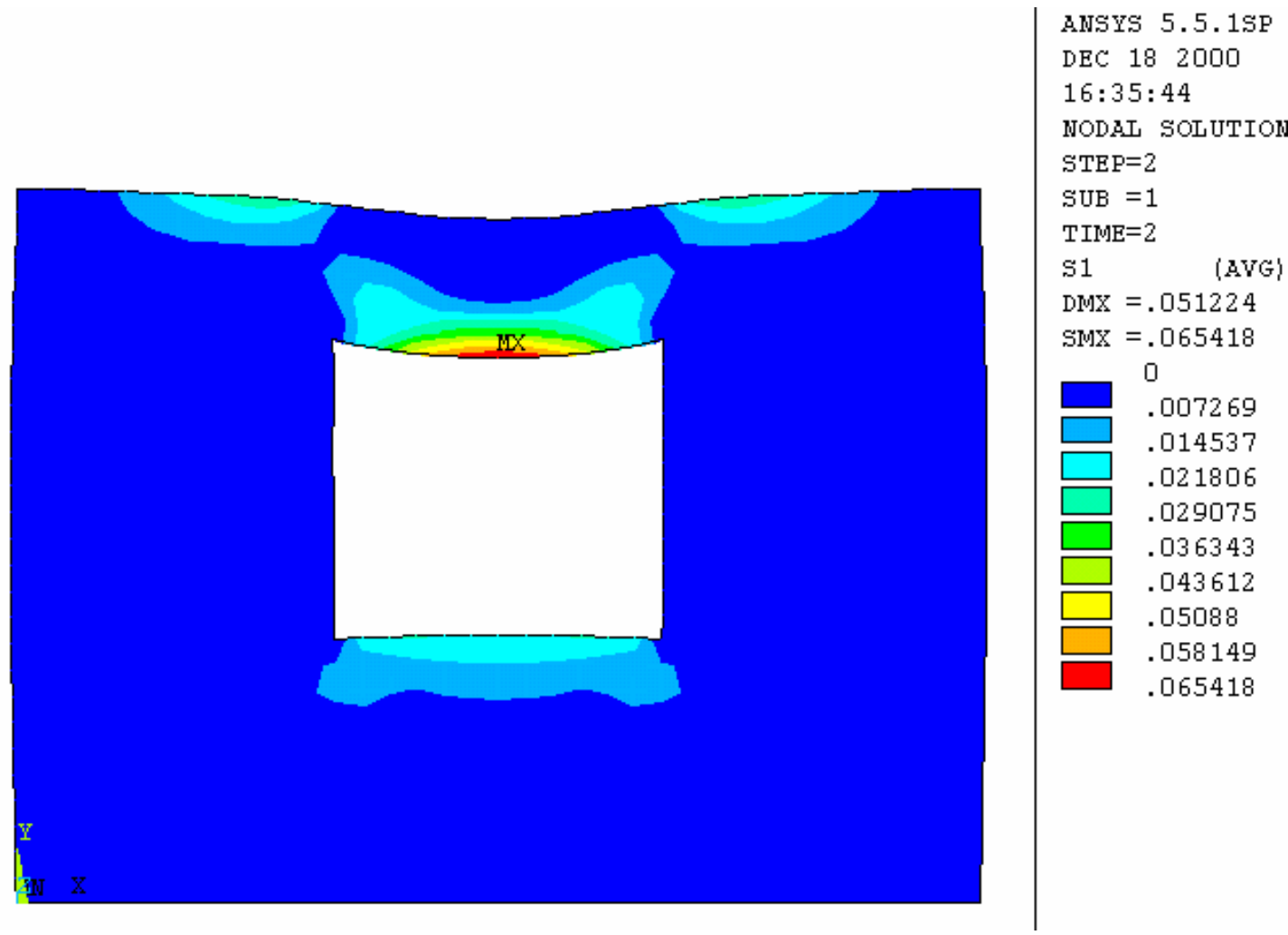

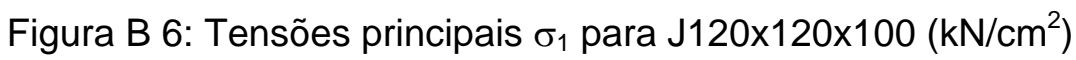




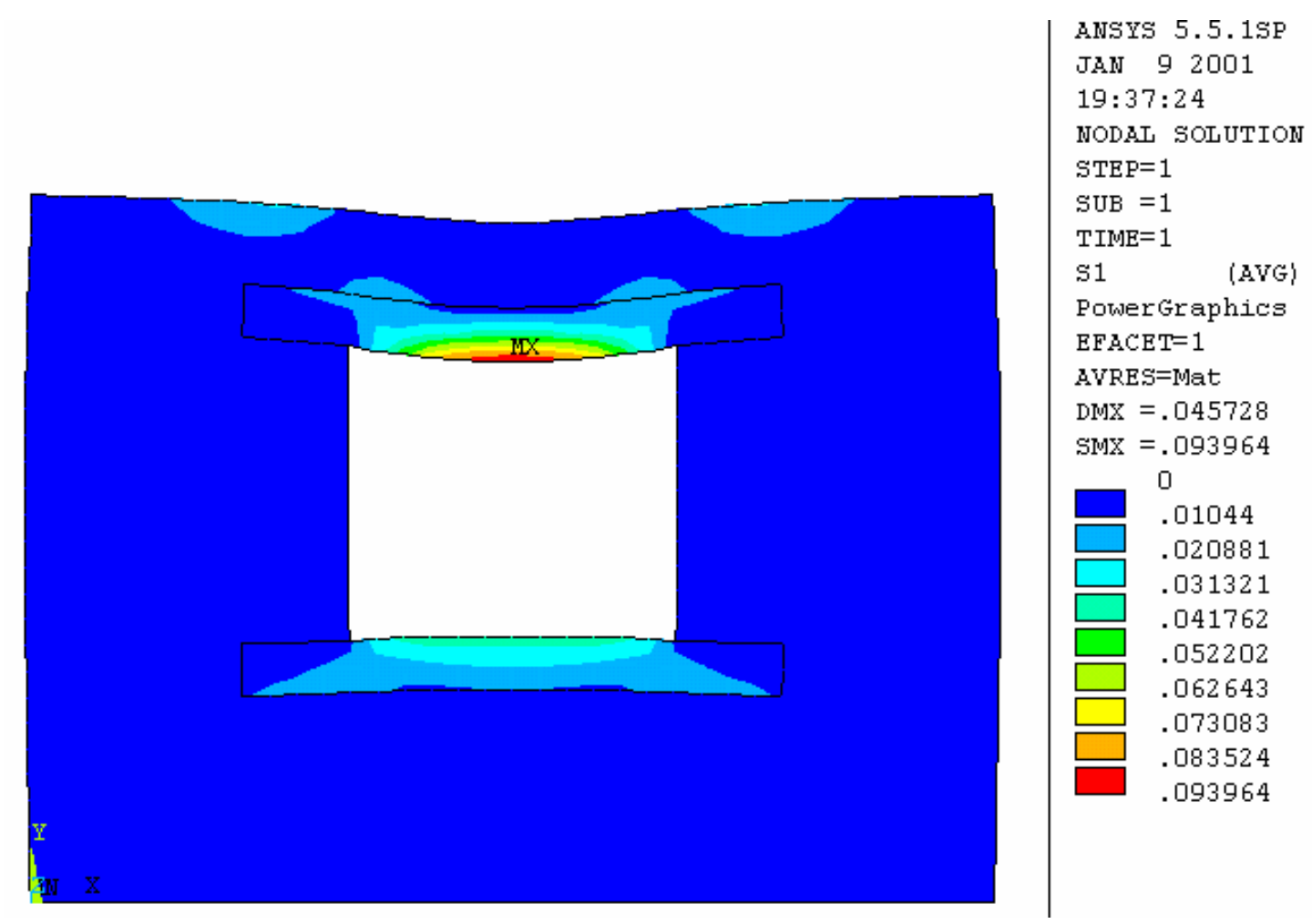

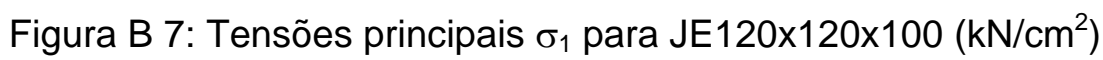

A análise das figuras, apresentadas neste anexo, se encontra no capítulo 5, juntamente com as ilustrações dos demais resultados da modelagem numérica. 


\section{BIBLIOGRAFIA}

ACCETTI, K.M. (1998). Contribuições ao projeto estrutural de edifícios em alvenaria. São Carlos. 245p. Dissertação (Mestrado). Escola de Engenharia de São Carlos, Universidade de São Paulo.

AGNESINI, M.V.C.; GOMES NETO, D.P. (1998). Microconcretos leves com argila expandida: influência da adição de sílica ativa no fator de eficiência em dosagens para pré-fabricados de pequena espessura - estudo de caso. In: CONGRESSO BRASILEIRO DO CONCRETO, 40, Rio de Janeiro, 1998. Anais. Rio de Janeiro.

AKASAKI, J.L. (1995). Alvenaria estrutural com blocos de concreto - a evolução dos materiais, equipamentos e mão-de-obra - uma experiência em São José do Rio Preto. São Carlos. 125p. Dissertação (Mestrado) - Escola de Engenharia de São Carlos, Universidade de São Paulo.

ALBUQUERQUE, A.J.P.; ALMEIDA FILHO, N.B.; BARRETO, N.R.A.S. (1996). Concreto de agregado leve reforçado com fibra de poliéster. In: REIBRAC, Ribeirão Preto, 1996. Anais. São Paulo, v.2, p.481-97.

AMERICAN CONCRETE INSTITUTE (1987). ACI 213. Guia para concreto estrutural de agregado leve.

AMERICAN CONCRETE INSTITUTE (1994). ACI 308/92 - Standard practice for curing concrete. Detroit, Michigan.

ASSOCIAÇÃO BRASILEIRA DA CONSTRUÇÃO INDUSTRIALIZADA (1990). Manual técnico de alvenaria . São Paulo, ABCI/Projeto. 
ASSOCIAÇÃO BRASILEIRA DE NORMAS TÉCNICAS (1977). NBR 5706 - Norma brasileira da coordenação modular da construção. Rio de Janeiro.

ASSOCIAÇÃO BRASILEIRA DE NORMAS TÉCNICAS (1982). NBR 5712 - Bloco vazado modular de concreto. Rio de Janeiro.

ASSOCIAÇÃO BRASILEIRA DE NORMAS TÉCNICAS (1982). NBR 5717 - Espaço modular para escadas. Rio de Janeiro.

ASSOCIAÇÃO BRASILEIRA DE NORMAS TÉCNICAS (1981). NBR 5722 Esquadrias modulares. Rio de Janeiro.

ASSOCIAÇÃO BRASILEIRA DE NORMAS TÉCNICAS (1981). NBR 5728 Detalhes modulares de esquadrias. Rio de Janeiro.

ASSOCIAÇÃO BRASILEIRA DE NORMAS TÉCNICAS (1978). NBR 6118 - Projeto e execução de obras de concreto armado. Rio de Janeiro.

ASSOCIAÇÃO BRASILEIRA DE NORMAS TÉCNICAS (1978) NBR 6118 - Projeto e execução de obras de concreto armado. Rio de Janeiro. Revisão de 2000.

ASSOCIAÇÃO BRASILEIRA DE NORMAS TÉCNICAS (1980) NBR 6120 - Cargas para o cálculo de estruturas de edificações. Rio de Janeiro.

ASSOCIAÇÃO BRASILEIRA DE NORMAS TÉCNICAS (1994). NBR 6136 - Blocos vazados de concreto simples para alvenaria estrutural. Rio de Janeiro.

ASSOCIAÇÃO BRASILEIRA DE NORMAS TÉCNICAS (1992). NBR 7171 - Bloco cerâmico para alvenaria. Rio de Janeiro.

ASSOCIAÇÃO BRASILEIRA DE NORMAS TÉCNICAS (1985). NBR 8798 Execução e controle de obras de alvenaria estrutural de blocos vazados de concreto. Rio de Janeiro.

ASSOCIAÇÃO BRASILEIRA DE NORMAS TÉCNICAS (1986). NBR 8800 - Projeto e execução de estruturas de aço de edifícios. Rio de Janeiro.

ASSOCIAÇÃO BRASILEIRA DE NORMAS TÉCNICAS (1985). NBR 9062 - Projeto e execução de estruturas de concreto pré-moldado. São Paulo. 
ASSOCIAÇÃO BRASILEIRA DE NORMAS TÉCNICAS (2000). NBR 10821 Caixilhos para edificações - janela. Rio de Janeiro.

ASSOCIAÇÃO BRASILEIRA DE NORMAS TÉCNICAS (1989). NBR 10837 Cálculo de alvenaria estrutural de blocos vazados de concreto. Rio de Janeiro.

BASSO, A.; CORRÊA, M.R.S.; RAMALHO, M.A. (1997). Fissuras em paredes de alvenaria estrutural sob lajes de cobertura de edifícios. In: CONGRESSO IBERO AMERICANO DE PATOLOGIA DAS CONSTRUÇÕES, 4./CONGRESSO DE CONTROLE DE QUALIDADE, 6. Porto Alegre, 1997. Anais. Porto Alegre, UFRGS-CPGED. v.1, p. 367-74.

BANCO NACIONAL DA HABITAÇÃO; INSTITUTO DE DESENVOLVIMENTO ECONÔMICO E GERENCIAL (1976). Coordenação modular da construção. São Paulo: BNH.

BENTES, R.F. (1992). Considerações sobre projeto e produção de componentes pré-fabricados de argamassa armada. 155p. Dissertação (Mestrado) - Escola de Engenharia de São Carlos, Universidade de São Paulo.

BENTES, R.F. (1993). O desafio da garantia da qualidade na produção de pré-moldados leves. In: III SIMPÓSIO IBERO AMERICANO SOBRE TÉCNICAS CONSTRUTIVAS INDUSTRIALIZADAS PARA HABITAÇÃO DE INTERESSE SOCIAL, São Paulo, 1993. Anais. São Paulo: IPT. v.1, p. 3-12.

BOCCHI JUNIOR, C.F. (1995). Lajes nervuradas de concreto armado: projeto e execução. São Carlos. Dissertação (Mestrado). Escola de Engenharia de São Carlos, Universidade de São Paulo.

BRITISH STANDARD INSTITUTION. (1992). BS 5628 - Code of practice for structural use of masonry. Part 1. Unreinforced masonry. Londres, Inglaterra.

CARRARO, F. (1998). Caracterização da tecnologia construtiva empregada na grande São Paulo para execução da estrutura e da alvenaria das edificações. In: CONGRESSO LATINO-AMERICANO DA TECNOLOGIA E GESTÃO NA PRODUÇÃO DE EDIFÍCIOS - SOLUÇÕES PARA O TERCEIRO MILÊNIO. São Paulo, 1998. Anais. São Paulo, v.2, p.45-53. 
CLARKE, J.L. (1993). Structural lightweight aggregate concrete. London, Blackie academic \& Professional.

CORRÊA, M.R.S.; RAMALHO, M.A. (1994). Procedimentos para análise de edifícios de alvenaria estrutural submetidos a ações verticais. In: 5th INTERNATIONAL SEMINAR ON STRUCTURAL MASONRY FOR DEVELOPING COUNTRIES, 5., Florianópolis, BR, 1994. Anais. Florianópolis, UFSC / University of Edinburgh / ANTAC. v.1, p.305-14.

DORNELLES, V.P.; SABBATINI, F.H. (1993). O planejamento racional da produção nos sistemas construtivos em alvenaria estrutural não armada. In: III SIMPÓSIO IBERO AMERICANO SOBRE TÉCNICAS CONSTRUTIVAS INDUSTRIALIZADAS PARA HABITAÇÃO DE INTERESSE SOCIAL, São Paulo, 1993. Anais. São Paulo, IPT. v.1, p.40-49.

DROPPA JUNIOR, A. (1999). Análise estrutural de lajes formadas por elementos pré-moldados tipo vigota com armação treliçada. São Carlos. Dissertação (Mestrado). Escola de Engenharia de São Carlos, Universidade de São Paulo.

EICKHOFF, M. (1997). A coordenação modular como instrumento para atingir a qualidade total em projetos de arquitetura. São Paulo. 159p. Dissertação (Mestrado). Faculdade de Arquitetura e Urbanismo, Universidade de São Paulo.

EL DEBS, M.K. (2000). Concreto pré-moldado: fundamentos e aplicações. São Carlos. Escola de Engenharia de São Carlos/USP - projeto REENGE.

FRANCO, L.S. (1987). Desempenho estrutural do elemento parede de alvenaria empregado na alvenaria estrutural não armada, quando submetido a esforços de compressão. 369p. Dissertação (Mestrado) - Escola Politécnica, Universidade de São Paulo.

FRANCO, L.S. et alii (1991a). Desenvolvimento de um novo processo construtivo em alvenaria estrutural não armada de blocos de concreto; manual do processo construtivo POLI-ENCOL; projeto. São Paulo. /Relatório técnico R5-25/91, EPUSP/ 
FRANCO, L.S. et alii (1991b). Desenvolvimento de um novo processo construtivo em alvenaria estrutural não armada de blocos de concreto; manual do processo construtivo POLI-ENCOL: blocos e pré-moldados. São Paulo. /Relatório técnico R5-26/91, EPUSP/

FRANCO, L.S. et alii (1991c). Desenvolvimento de um novo processo construtivo em alvenaria estrutural não armada de blocos de concreto; manual do processo construtivo Poli/ENCOL: execução. São Paulo. /Relatório Técnico R5-27/91 EPUSP/

FRANCO, L.S. (1992). Aplicação de diretrizes de racionalização construtiva para a evolução tecnológica dos processos construtivos em alvenaria estrutural não armada. 319p. Tese (Doutorado) - Escola Politécnica, Universidade de São Paulo.

FRANCO, L.S.; AGOPYAN, V. (1994). Racionalização dos processos construtivos em alvenaria estrutural não armada. In: 5th INTERNATIONAL SEMINAR ON STRUCTURAL MASONRY FOR DEVELOPING COUNTRIES, Florianópolis, BR, 1994. Anais. Florianópolis, UFSC/ University of Edinburg/ ANTAC. v.1, p.497-508.

FÉDÉRATION INTERNATIONALE DE LA PRÉCONTRAINTE (1994). Planning and design handbook on precast building structures. Londres, Seto.

FERREIRA JUNIOR, S. (1995). Produção de blocos de concreto para alvenaria prática recomendada. 3.ed. São Paulo, ABCP.

FERREIRA, E.A.M. (1991). Diretrizes para garantia da qualidade em construções industrializadas: uma aplicação à tecnologia da argamassa armada. São Carlos. 164p. Dissertação (Mestrado). Escola de Engenharia de São Carlos, Universidade de São Paulo.

FERREIRA, E.A.M.; DORNELLES, V.P.; ALY, V.L.C.; SABBATINI, F.H. (1994). Metodologia de controle da qualidade de execução para sistemas construtivos em alvenaria estrutural não armada. In: 5th INTERNATIONAL SEMINAR ON STRUCTURAL MASONRY FOR DEVELOPING COUNTRIES, Florianópolis, BR, 1994. Anais Florianópolis: UFSC/ University of Edinburg/ ANTAC. v.1, p.529-538. 
FUSCO, P.B. (1995). Técnica de armar as estruturas de concreto. São Paulo, Pini.

GIASSETTI. (2000). Sistemas industrializados. São Paulo. /catálogo/

GRANDJEAN, E. (1991). Manual de ergonomia: adaptando o trabalho ao homem. Trad. por João Pedro Stein. 4.ed. Porto Alegre, Bookman.

HAMASSAKI, L.Y.; SBRIGHI NETO, C.; FLORINDO, M.C. (1996). Uso de entulho como agregado para argamassa de alvenaria. In: RECICLAGEM E REUTILIZAÇÃO DE RESÍDUOS COMO MATERIAIS DE CONSTRUÇÃO CIVIL. São Paulo, 1996. Anais. São Paulo, Epusp. Workshop. p.107-115.

HANAI, J.B. (1992). Construções de argamassa armada: fundamentos tecnológicos para projeto e execução. São Paulo, Pini.

HANAI, J.B.; EL DEBS, M.K. (1993). Uma revisão da aplicação da argamassa armada (ferrocimento) em habitações. In: III SIMPÓSIO IBERO AMERICANO SOBRE TÉCNICAS CONSTRUTIVAS INDUSTRIALIZADAS PARA HABITAÇÃO DE INTERESSE SOCIAL, São Paulo, 1993. Anais. São Paulo, IPT. v.2, p 435-446.

HEINECK, L.F.M. (1991). Efeito continuidade e efeito concentração no aumento da produtividade nas alvenarias. In: SIMPÓSIO DE DESEMPENHO DE MATERIAIS E COMPONENTES DE CONSTRUÇÃO CIVIL, 3. Florianópolis, 1991. Anais. Florianópolis, UFSC. P.67-75.

HEINECK, L.F.M.; ANDRADE, V.A. (1994). A racionalização da execução de alvenarias do tipo convencional e estrutural através de inovações tecnológicas simples. In: 5th INTERNATIONAL SEMINAR ON STRUCTURAL MASONRY FOR DEVELOPING COUNTRIES, Florianópolis, BR, 1994. Anais. Florianópolis, UFSC/ University of Edinburg/ ANTAC, v.1, p.584-593.

IIDA, I. (1973). Ergonomia - projeto e produção. São Paulo, Edgar Blücher Ltda.

JOHN, V.M. (1996). Pesquisa e desenvolvimento de mercado para resíduos. In: RECICLAGEM E REUTILIZAÇÃO DE RESÍDUOS COMO MATERIAIS DE CONSTRUÇÃO CIVIL. São Paulo, 1996. Anais. São Paulo, Epusp, Workshop. p.21-30. 
KISS, P. (1998). Alvenaria de montagem. Construção São Paulo, n.2621, p.14-17, Maio.

LATTERZA, L.M. (1998). Concreto com agregado graúdo proveniente da reciclagem de resíduos de construção e demolição. Um novo material para fabricação de painéis leves de vedação. São Carlos. Dissertação (Mestrado). Universidade de São Paulo, Escola de Engenharia de São Carlos.

LEONHARDT, F, MÖNNING, E. (1978). Construções de concreto. Rio de Janeiro, Interciência, v.1.

LEVY, S.M.; HELENE, P.R.L. (1996). Propriedades mecânicas de argamassas produzidas com entulho de construção civil. In: RECICLAGEM E REUTILIZAÇÃO DE RESÍDUOS COMO MATERIAIS DE CONSTRUÇÃO CIVIL. São Paulo, 1996. Anais. São Paulo, Epusp, Workshop, p.137-146.

LICHTENSTEIN, N.B. (1987). Formulação de modelo para o dimensionamento do sistema de transporte em canteiro de obras de edifícios de múltiplos andares. São Paulo. 268p. Tese (Doutorado) - Escola Politécnica, Universidade de São Paulo.

LUCINI, H.C. (2001). Manual técnico de modulação de vãos de esquadrias. São Paulo, Pini.

MAGALHÃES, F.L. (2001). Estudo dos momentos fletores negativos nos apoios de lajes formadas por elementos pré-moldados tipo nervuras com armação treliçada. Dissertação (Mestrado) - Escola de Engenharia de São Carlos, Universidade de São Paulo.

MASSONI, R.F.A.P. (1996). Formas estruturais de argamassa e concreto para elementos de concreto armado. 169p. Dissertação (Mestrado) - Escola de Engenharia de São Carlos, Universidade de São Paulo.

MATTOS, A.D. (1997). Boas vibrações para sua obra. Téchne, n.29, p.44-46, jul/ago. 
MEDEIROS, J.S.; SABBATINI, F.H. (1994). Componentes pré-moldados de concreto armado para a construção de edifícios habitacionais. In: 5th INTERNATIONAL SEMINAR ON STRUCTURAL MASONRY FOR DEVELOPING COUNTRIES, 1994, Florianópolis, BR, 1994. Anais Florianópolis: UFSC/ University of Edinburg/ ANTAC. v.1, p.491-497.

MEDEIROS, J.S.; DORNELLES, V.P.; FRANCO L.S. (1994). Blocos de concreto para alvenaria estrutural: avaliação de parâmetros básicos de produção. In: 5th INTERNATIONAL SEMINAR ON STRUCTURAL MASONRY FOR DEVELOPING COUNTRIES, 1994, Florianópolis, BR, 1994. Anais. Florianópolis: UFSC/ University of Edinburg/ ANTAC. p.462-70.

MEHTA, P.K.; MONTEIRO, P.J.M. (1994). Concreto: estrutura, propriedades e materiais. São Paulo, Pini.

MEKBEKIAN, G. (1997). Desenvolvimento de sistemas de qualidade para indústrias de pré-fabricados de concreto de acordo com as diretrizes da série de normas NBR ISO 9000. São Paulo. 150p. Dissertação (Mestrado) - Escola Politécnica, Universidade de São Paulo.

MELGES, J.L.P.; PINHEIRO, L.M.; GIONGO, J.S. (1997). Concreto armado: escadas. São Carlos. Escola de Engenharia de São Carlos, Universidade de São Paulo.

MINISTÉRIO DO TRABALHO (1996). NR 18 - Condições e meio ambiente do trabalho na indústria da construção. Fundacentro.

MINISTÉRIO DO TRABALHO (1999). NR 17 - Ergonomia. Fundacentro.

MUTTI, C.N.; ROMAN, H.R. (1998). Ergonomização de postos de trabalho na execução de prédios em alvenaria. In: VII ENCONTRO NACIONAL DE TECNOLOGIA DO AMBIENTE CONSTRUÍDO - QUALIDADE NO PROCESSO CONSTRUTIVO. Florianópolis,1998. Anais. Santa Catarina, v.2, p.193-198.

OLIVEIRA, R.I. (1994). Sistematização e listagem de fatores que afetam a construtibilidade das alvenarias estruturais. In: 5th INTERNATIONAL SEMINAR ON STRUCTURAL MASONRY FOR DEVELOPING COUNTRIES, 
1994, Florianópolis, BR, 1994. Anais. Florianópolis: UFSC/ University of Edinburg/ ANTAC. v.1, p.417-26.

QUALIDADE NA CONSTRUÇÃO (1999). O desperdício do Silêncio. São Paulo, ano3, n.20, p.24.

RODRIGUES, P.P.F. (1989). Controle de qualidade na indústria de prefabricados. São Paulo. Dissertação (Mestrado) - Escola Politécnica, Universidade de São Paulo.

ROMAN, H.R.; SINHA, B.P. (1994). Shear strength of concrete block masonry. In: 5th INTERNATIONAL SEMINAR ON STRUCTURAL MASONRY FOR DEVELOPING COUNTRIES, 1994, Florianópolis, BR, 1994. Anais. Florianópolis: UFSC/ University of Edinburg/ ANTAC. v.1, p.251-259.

ROMANO, E. (1993). A casa 2001: o desafio na virada do milênio. In: III SIMPÓSIO IBERO AMERICANO SOBRE TÉCNICAS CONSTRUTIVAS INDUSTRIALIZADAS PARA HABITAÇÃO DE INTERESSE SOCIAL. São Paulo, 1993. Anais. São Paulo, IPT. v.1, p.197-210.

ROSSO, T. (1966). Pré-fabricação, a coordenação modular :teoria e pratica. São Paulo, Instituto de Engenharia.

ROSSO, T. (1976). Teoria e prática da coordenação modular. Faculdade de arquitetura e urbanismo /USP. Curso de pós graduação. Disciplina: Teoria e prática da coordenação modular.

SAURIN, T.A.; FORMOSO, C.T. (1998). Método para diagnóstico de canteiros de obra de edificações. In: VII ENCONTRO NACIONAL DE TECNOLOGIA DO AMBIENTE CONSTRUÍDO: QUALIDADE NO PROCESSO CONSTRUTIVO. Florianópolis, 1998. Anais. Florianópolis, SC. v.1, p.749-756.

SOBRAL, H.S. (1987). Concretos leves - tipos e comportamento estrutural. São Paulo, ABCP.

SOUZA, U.E.L. (2000). Projeto e implantação do canteiro. São Paulo, Tula Melo. (Coleção Primeiros Passos da Qualidade no Canteiro de Obras). 
SOUZA, R.; MEKBEKIAN, G. (1996). Qualidade na aquisição de materiais e execução de obras. São Paulo, Pini.

TAUIL, C.A.; RACCA, C.L. (1981). Alvenaria armada. São Paulo, Projeto.

TEZUKA, Y. (1989). Concreto armado com fibras. São Paulo, ABCP.

VILATÓ, R.R. (1998). Estudo da metodologia do projeto para edifícios em alvenaria estrutural não armada. 175p. Dissertação (Mestrado) - Escola Politécnica, Universidade de São Paulo.

WINBLOCK (1999). Tecnologia em painel de concreto para iluminação e ventilação. São Paulo. /catálogo/

YAZIGI, W. (1998). A técnica de edificar. São Paulo, Pini. 